\title{
COMPORTAMENTO DE ESTACAS SUBMETIDAS A ESFORÇOS VERTICAIS DE TRAÇÃO, EM SOLO COLAPSÍVEL
}

Dissertação apresentada à Escola de Engenharia de São Carlos, da Universidade de São Paulo, como parte dos requisitos para obtenção do Título de Mestre em Geotecnia.

ORIENTADOR: Prof. Dr. J. C. ANGELO CINTRA

\section{São carlos}




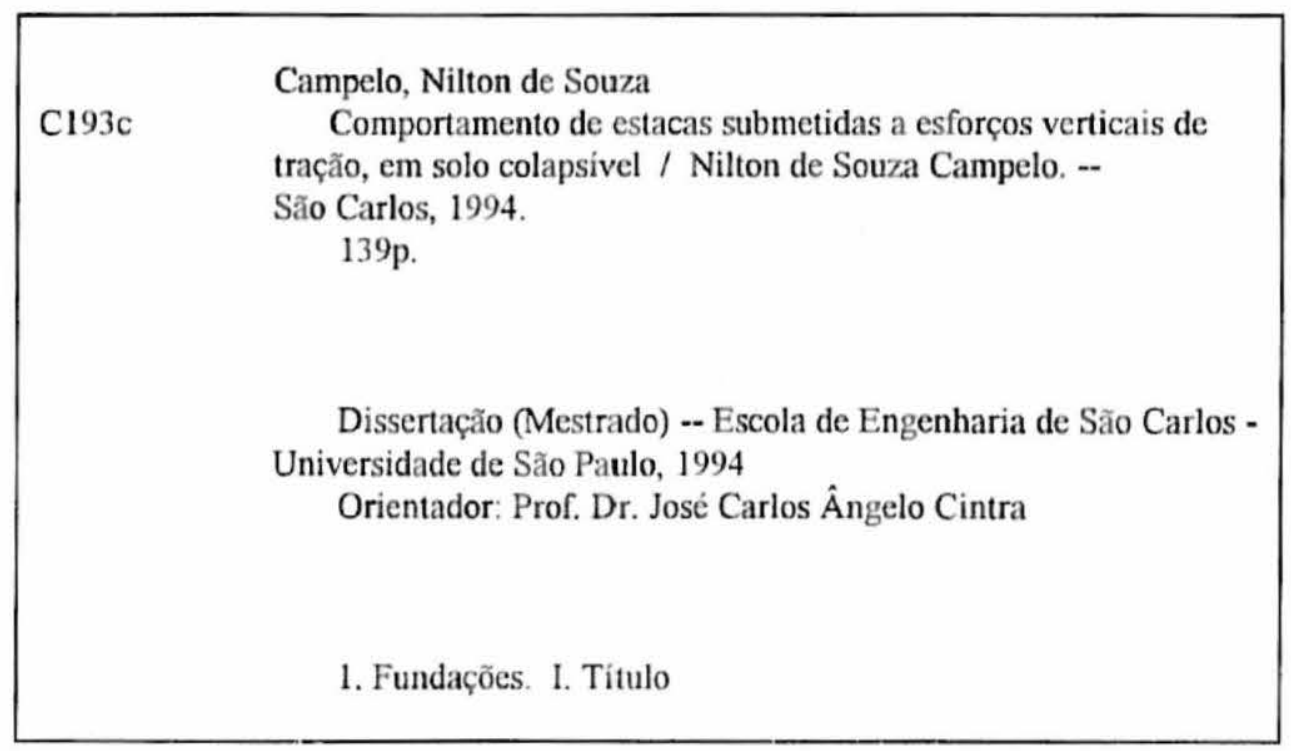


Omnia Mecum Porto Mea (Bias, Séc. IV a.C.)

Si Quis Vult Primus Esse, Eret Omnium Novissimus et Ominium Minister (Lc 9,35b) 
A

João de Sá R. Campelo,

Pater et Amici

e a

Lila S. Campelo,

Mater et Magistra

dedico, ab imo core 


\section{AGRADECIMENTOS}

Ao Prof. Dr. J. C. ANGELO CINTRA, pela orientação, paciência e amizade demonstrada ao longo de todo o desenvolvimento deste trabalho.

Ao Prof. Dr. J. H. ALBIERO, pelas primeiras orientações e sugestões, dadas a este trabalho.

Ao Departamento de Transportes da Universidade do Amazonas, pela liberação do meu afastamento e em particular ao Prof. PAULO CÉZAR AMORIM, pela sincera amizade criada durante a minha permanência no departamento.

Ao Prof. Dr. ROGÉRIO COELHO LOPES, do Departamento de Estruturas da Universidade do Amazonas, pelo estimulo prestado à minha carreira acadêmica, desde o tempo da graduação em Engenharia Civil.

Ao amigo Prof. JOZINO MACIEL BASTOS, in memoriam, e a MAJU BASTOS, pelo tratamento sempre carinhoso dispensado para comigo.

Ao prezado amigo Dr. HERIVELTO MOREIRA DOS SANTOS, pela amizade, dedicação e ensinamentos na área de informática.

Ao carissimo amigo Eng. ${ }^{\circ}$ BENEDITO IMBIRIBA CARNEIRO, pelo companheirismo e presteza dedicados durante a nossa permanência neste Estabelecimento, meus sinceros agradecimentos, $a b$ imo pectore.

Aos amigos Engenheiros MARCOS MACACARI, PAULO ANDRÉ D'ÁVILA e J. C. FERNANDES, pela colaboração na realização dos ensaios de campo.

Aos professores, funcionários, e demais colegas do Departamento de Geotecnia, pelo convivio harmonioso e paciente, e em particular, às prezadas senhoras REGINA DIBO, MARISTELA BATISSACO e SILVIA SVERZUT, pela presteza dispensada.

Às caras senhoras HELENA PERES e ELENA GONÇALVES, da Biblioteca Central, pela cordialidade no atendimento dos serviços bibliotecários.

À FAPESP, pelo apoio financeiro na realização deste trabalho.

Aos meus pais e irmãos, pelo amor fraterno e amizade incondicional. 


\section{SUMÁRIO}

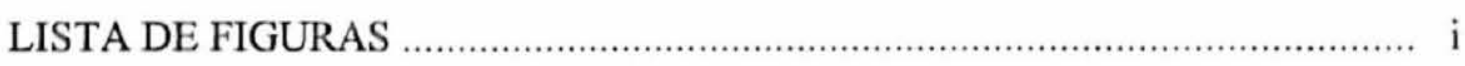

LISTA DE TABELAS ........................................................................... iv

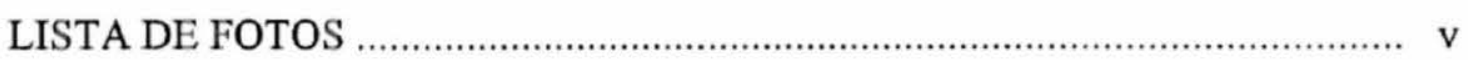

LISTA DE SÍMBOLOS ….................................................................... vi

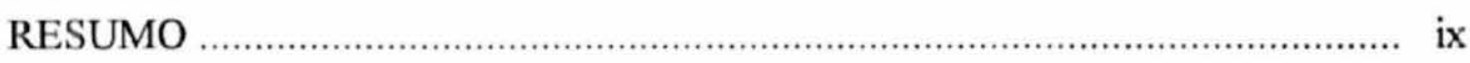

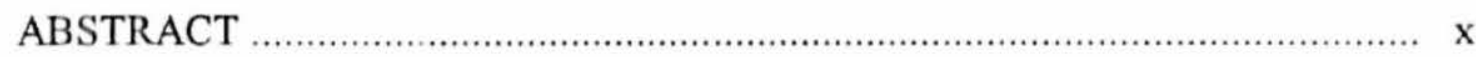

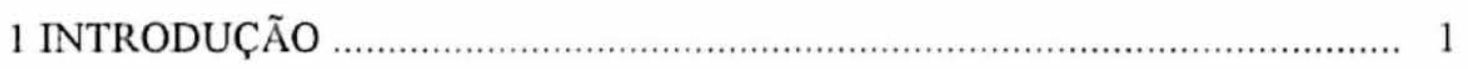

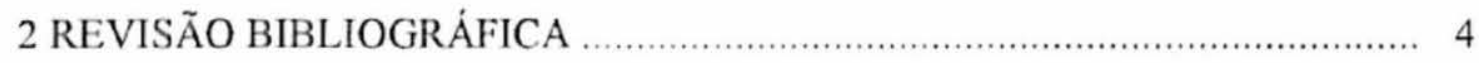

2.1 Colapsibilidade de Solos ................................................................... 4

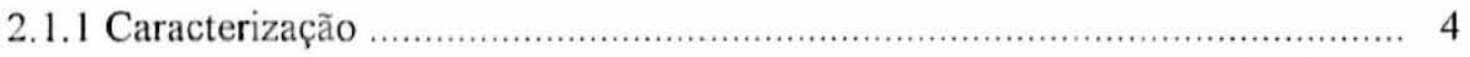

2.1.2 Áreas de ocorrência ........................................................................ 6

2.2. Métodos de Previsão da Capacidade de Carga de Fundações

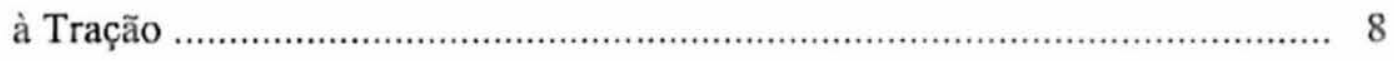

2.2.1 Considerações iniciais ......................................................................... 8

2.2.2 O método do tronco de cone (ou de pirâmide) …................................. 9

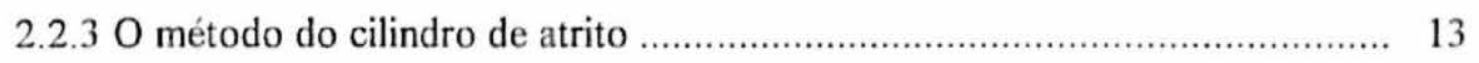

2.2 .40 método de Meyerhof \& Adams ..................................................... 15

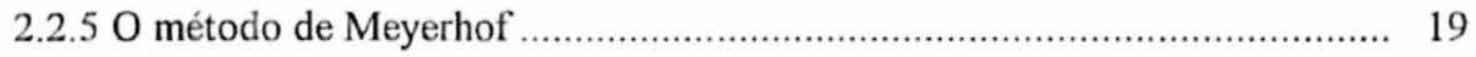

$2.2 .6 \mathrm{O}$ método de Grenoble .................................................................. 22

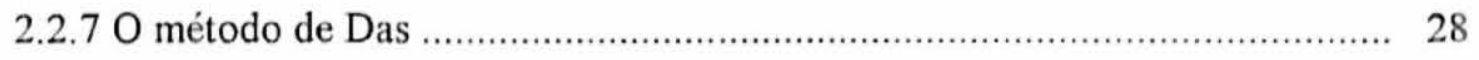

2.2 .80 método da teoria da resistência lateral ............................................... 30

2.3 Avaliação dos Parâmetros Geotécnicos do Solo e do

Conjunto Estaca-Solo ......................................................................... 32

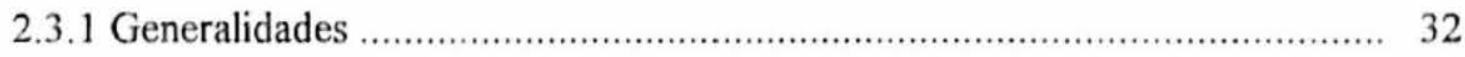

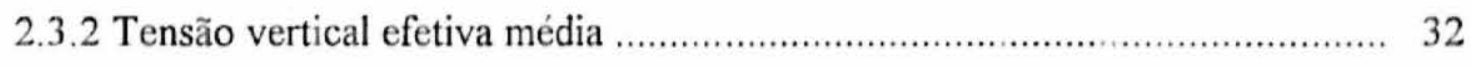

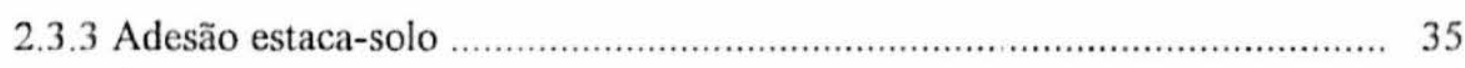

2.3.4 Ângulo de atrito da interface estaca-solo ............................................... 36 
2.3.5 Coeficiente de empuxo horizontal 40

2.4 Relação entre os Atritos Laterais em Estacas Tracionadas e Comprimidas . 42

2.5 Influência do Tempo de carregamento em Provas de Carga e de

Recarregamentos em Fundações

2.6 Efeito da Inundação de um Solo Colapsivel na Capacidade de Carga de

Estacas Submetidas a Esforços de Compressão e Tração .............................. 51

2.6.1 Generalidades ................................................................................ 51

2.6.2 Processos de inundação das camadas colapsíveis ................................... 51

2.6.3 Redução da carga última de fundações devida a inundação do terreno ......... 56

3 CAMPO EXPERIMENTAL DE FUNDAÇÕES DA USP/SÃO CARLOS ....... 61

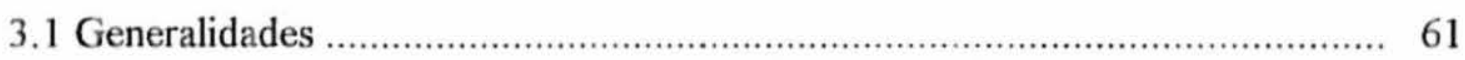

3.2 Caracterização Geotécnica .................................................................... 61

3.3 Execução das Estacas Submetidas a Esforços de Tração .............................. 63

3.4 Execução das Estacas de Reação .................................................................... 64

4 METODOLOGIA E EQUIPAMENTOS UTILIZADOS

NAS PROVAS DE CARGA ….................................................................. 65

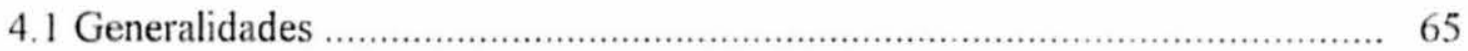

4.2 Equipamentos e Materias Utilizados …................................................... 65

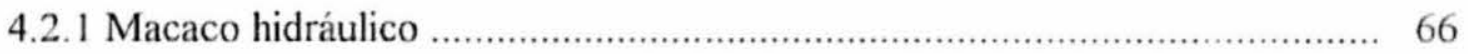

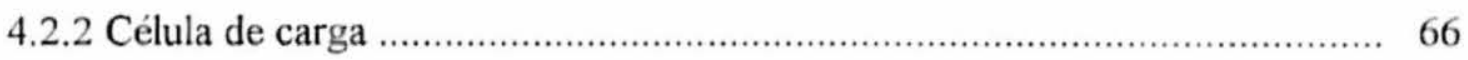

4.2.3 Indicador de deformação ...................................................................... 66

4.2.4 Relógios comparadores .......................................................................... 66

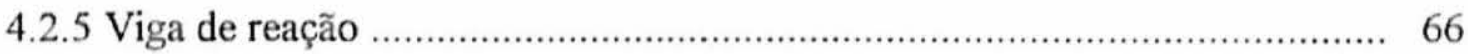

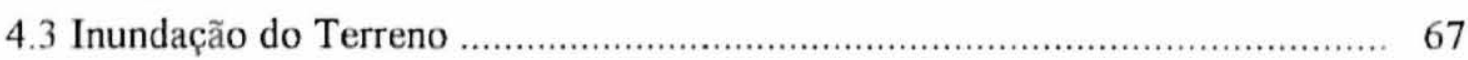

4.4. Seqüência das Provas de Carga …........................................................ 69

5 ANÁLISE DOS RESULTADOS _............................................................... 71

5.1 Generalidades .............................................................................. 71

5.2 Parâmetros Geotécnicos do Solo e do Conjunto Estaca-Solo ...................... 71

5.3 Cargas Máximas Obtidas nas Provas de Carga e

Respectivos Ajustamentos ...................................................................... 72

5.4 Curvas Carga x Deslocamento ....................................................................... 72

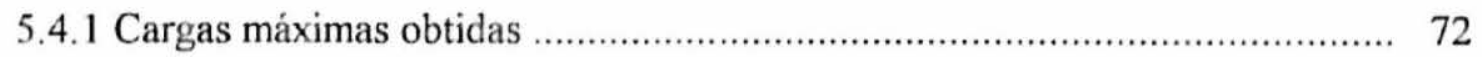

5.4.2 Influência da inundação do solo nas cargas últimas ................................. 74

5.4.3 Efeito da velocidade de carregamento nas cargas últimas ........................ 80 
5.4.4 Efeito de carregamentos sucessivos ............................................... 81

5.4.5 Efeito do apiloamento do solo .......................................................... 82

5.4.6 Deslocamentos nas cargas de trabalho e de ruptura ................................ 82

5.4.7 Atrito lateral médio ........................................................................... 82

5.5 Comparação entre as Cargas Últimas Estimadas e

Obtidas nas Provas de Carga .............................................................. 83

5.5.1 Considerações sobre o método do tronco de cone ................................... 85

5.5.2 Considerações sobre o método de Meyerhof \& Adams ............................. 86

5.5.3 Considerações sobre o método de Meyerhof ........................................ 86

5.5.4 Considerações sobre o método de Grenoble ......................................... 87

5.5.5 Considerações sobre o método de Das .................................................... 87

5.5.6 Considerações sobre o método da teoria da resistência lateral ................... 87

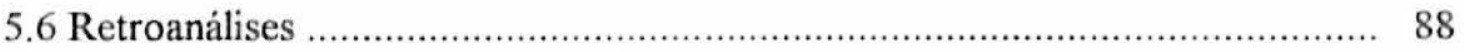

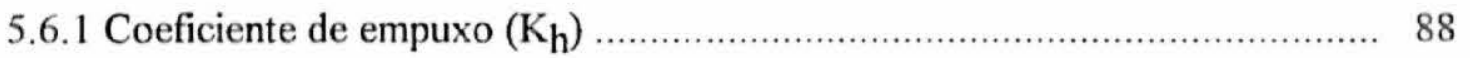

5.6.2 Ângulo da superficie de ruptura do método do tronco de cone ................. 89

5.7 Comparação dos Resultados Obtidos ................................................... 90

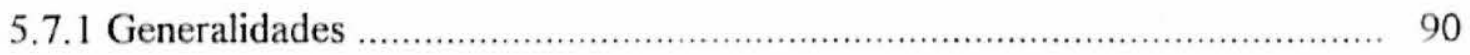

5.7.2 Ângulo da superficie de ruptura do método do tronco de cone $(\alpha)$............ 90

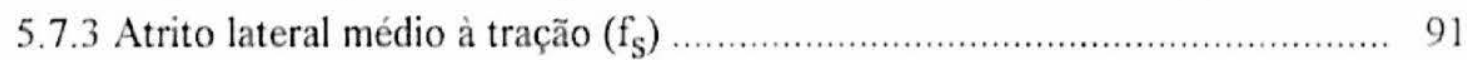

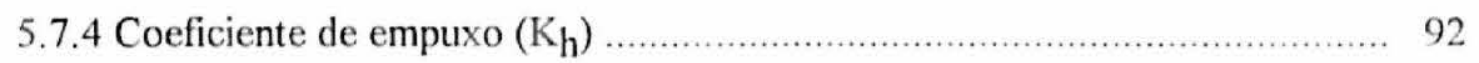

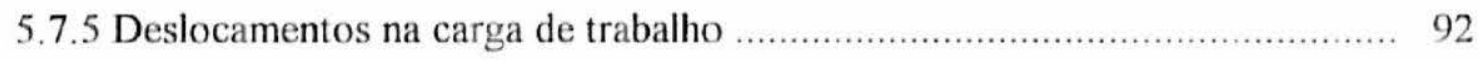

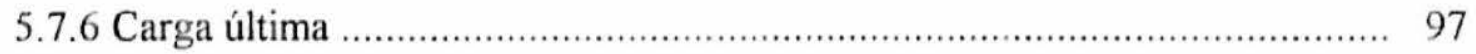

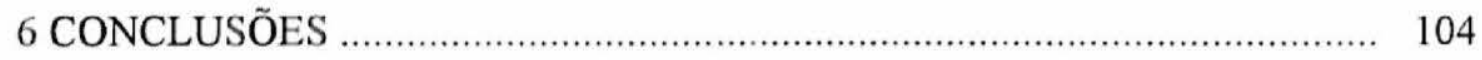

7 SUGESTÕES PARA FUTURAS PESQUISAS _....................................... 108

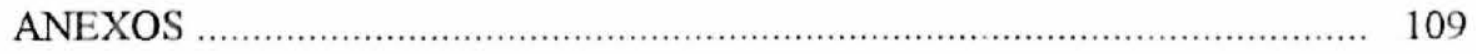

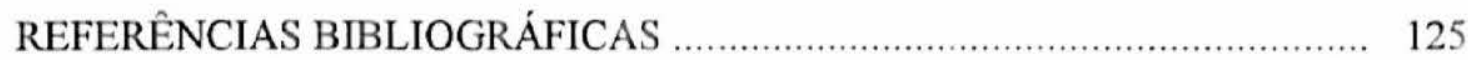

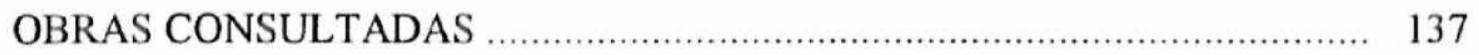




\section{LISTA DE FIGURAS}

FIGURA 2.1 - Método do Tronco de Cone (ou de Pirâmide)

Aplicado a Estacas

FIGURA 2.2 - Método do Cilindro de Atrito Aplicado a Estacas

FIGURA 2.3 - Superficies de Ruptura em Fundações Corridas

FIGURA 2.4 - Coeficientes Teóricos de Arrancamento (Ku) para

Estacas Escavadas

FIGURA 2.5 - Superficie de Ruptura para Estacas em Solos Homogêneos

FIGURA 2.6 - Ábaco do Coeficiente de Empuxo (f/H), em função de $\phi$ e $\lambda$, em Meio Coesivo

FIGURA 2.7 - Ábaco dos Termos de Coesão $\left(\mathrm{M}_{\mathrm{C}}\right)$, Atrito e Gravidade $\left(\mathrm{M}_{\phi}+\mathrm{M}_{\gamma}\right)$, em Função de $\phi$ e $\lambda$

FIGURA 2.8 - Variação de $\delta / \phi$ com $\mathrm{D}_{\mathrm{r}}$ 29

FIGURA 2.9 - Distribuição Simplificada da Tensão Vertical Adjacente à Estaca, em Areia

FIGURA 2.10 - Relação entre $R_{R}$ e $\delta / \phi$ 39

FIGURA 2.11 - Efeito da Inundação do Solo na Carga Última à Compressão de Estacas Escavadas e Apiloadas

FIGURA 2.12 - Curvas Carga x Deslocamento das Estacas

Ensaiadas à Tração. 60

FIGURA 3.1 - Perfil Típico do Campo Experimental de São Carlos 62 
FIGURA 3. 2 - Disposição das Estacas Analisadas, com as Respectivas

Estacas de Reação

FIGURA 4.1 - Esquema de uma Prova de Carga à Tração em uma Estaca

FIGURA 5.1 - Curvas Carga x Deslocamento das Estacas

01, 02, 03, 04 e 05

FIGURA 5.2 - Curvas Carga x Deslocamento da Estaca 01, com o

Solo no Estado Natural e Inundado

FIGURA 5.3 - Curvas Carga x Deslocamento da Estaca 02, com o

Solo no Estado Natural e Inundado 76

FIGURA 5.4 - Curvas Carga x Deslocamento da Estaca 03, com o

Solo no Estado Natural e Inundado

FIGURA 5.5 - Curvas Carga x Deslocamento da Estaca 04, com o

Solo no Estado Natural e Inundado 78

FIGURA 5.6 - Curvas Carga x Deslocamento da Estaca 05, com o Solo no Estado Natural e Inundado 79

FIGURA 5.7 - Curva Carga x Deslocamento da Estaca 02, para Sucessivos Carregamentos, com o Solo na Umidade Natural 80

FIGURA 5.8 - Curvas Carga x Deslocamento da Estaca 02, para Sucessivos Carregamentos e Deslocamentos Acumulados, com o Solo na Umidade Natural

FIGURA 5.8-A - Carga Última Prevista x Carga Última Medida, pelos Diversos Métodos $85 \mathrm{~A}$

FIGURA 5.9 - - Ângulo $\alpha$, em Função de L/D, para Diversos

Tipos de Fundações 93

FIGURA 5. 10 - Curva de Regressão Obtida para $\alpha$, em Função de L/D 94 
FIGURA 5.11 - Atrito Lateral Total Médio $\left(\mathrm{f}_{\mathrm{S}}\right)$, em Função de L/D 95

FIGURA 5.12 - Atrito Lateral Total Médio (f $\mathrm{f}_{\mathrm{s}}$ ), em Função de L/D e D 96

FIGURA 5.13 - Atrito Lateral Total Médio $\left(\mathrm{f}_{\mathrm{s}}\right)$, em Função de L/D e L 96

FIGURA 5.14 - Atrito Lateral Total Médio $\left(\mathrm{f}_{\mathrm{s}}\right)$, em Função de L e D 97

FIGURA 5.15 - Coeficiente de Empuxo $\left(\mathrm{K}_{\mathrm{h}}\right)$ em Função de L/D 98

FIGURA 5.16 - Coeficiente de Empuxo $\left(\mathrm{K}_{\mathrm{h}}\right)$ em Função de L/D e D 99

FIGURA 5.17 - Coeficiente de Empuxo $\left(K_{h}\right)$ em Função de L/D e L 99

FIGURA 5.18 - Coeficiente de Empuxo $\left(\mathrm{K}_{\mathrm{h}}\right)$ em Função de L eD 100

FIGURA 5.19 - Carga de Ruptura ( $\left.\mathrm{P}_{\mathrm{u}}\right)$, em Função de L/D e D 100

FIGURA 5.20 - Carga de Ruptura ( $\left.\mathrm{P}_{\mathrm{u}}\right)$, em Função de L e D 101

FIGURA 5.21 - Carga de Ruptura ( $\mathrm{P}_{\mathrm{u}}$ ), em Função de L/D e L 101

FIGURA 5.22 - Carga de Ruptura ( $\left.\mathrm{P}_{\mathrm{u}}\right)$, em Função de L/D 102

FIGURA 5.23 - Deslocamentos na Carga de Trabalho, em Relação ao Diâmetro da Fundação 103 


\section{LISTA DE TABELAS}

TABELA 2.1 - Valores dos Coeficientes m e Limites Máximos do Fator de Forma s, em Função de $\phi$ e de H/D 18

TABELA 2.2 - Valores de $\alpha_{\mathrm{T}}$ em Função de L/D e $\phi$ 33

TABELA 2.3 - Coeficientes de Adesão $(\alpha)$ para Estacas Escavadas em Argila 35

TABELA 2.4 - Valores de Coeficiente de Adesão da Interface Estaca-Solo, para Superficies de Concreto Lisa e Rugosa 36

TABELA 2.5 - Valores de Ângulo de Atrito Interno do Solo e da Interface Estaca-Solo, para Superficies de Concreto Lisa e Rugosa 37

TABELA 2.6 - Valores de Rugosidade, em Função da Granulometria da Areia 39

TABELA 4.1 - Seqüência de Realização das Provas de Carga nas Estacas Ensaiadas 70

TABELA 5.1 - Valores Médios dos Parâmetros do Subsolo Obtidos nos Ensaios Laboratoriais e Penetrométricos

TABELA 5.2 - Tipos, Caracteristicas Geométricas e Cargas de Ruptura das Estacas 72

TABELA 5.3 - Intervalos de Tempo para Início de Colapso 74

TABELA 5.4 - Redução da Carga Última Devida a Inundação 75

TABELA 5.5 - Deslocamentos Médios para 50\% e 90\% da Carga Última 82

TABELA 5.6 - Atrito Lateral Total Médio 83

TABELA 5.7 - Valor Médio da Carga Máxima e da Carga Última 84 
TABELA 5.8 - Cargas Últimas à Tração Previstas e Erros Relativos (\%) na Adoção dos Diversos Métodos

TABELA 5.9 - Retroanálise dos Parâmetros Utilizados nas Equações de Previsão de Cargas Últimas à Tração 88

TABELA 5.10 - Valores de $\mathrm{K}_{\mathrm{h}}$ Recomendados por Diversos Autores 89

TABELA 5.11 - Fundações Ensaiadas à Tração por Diversos Autores 91

TABELA 5.12 - Parâmetros Geotécnicos Obtidos por Diversos Autores 92

\section{LISTA DE FOTOS}

FOTO 4.1 - Equipamentos Utilizados nas Provas de Carga 68

FOTO 4.2 - Vista da Viga de reação 68

FOTO 4.3 - Cava em Torno do Topo da estaca, Inundada por Água 69 


\section{LISTA DE SÍMBOLOS}
$A_{1}$
- Área lateral do fuste da fundação $\left(\mathrm{m}^{2}\right)$
$\mathrm{c}$
- Coesão (em termos de tensão total) $(\mathrm{kPa})$
$c^{\prime}$
- Coesão (em termos de tensão efetiva) (kPa)
$\mathrm{c}_{\mathrm{a}}$
- Adesão entre a estaca e o solo $(\mathrm{kPa})$
$\mathrm{C}_{1}, \mathrm{C}_{2}$ e $\mathrm{C}_{3}$
- Coeficientes do método do tronco de cone
D
- Diâmetro (m)
$\mathrm{D}_{\mathrm{r}}$
- Compacidade Relativa (\%)
$f_{S}$
- Atrito lateral médio do solo no fuste da fundação $(\mathrm{kPa})$
$\mathrm{H}$
- Altura de alcande máximo da superficie de ruptura (m)
IC
- Índice de consistência
$\mathrm{K}_{\mathrm{h}}$
- Coeficiente de empuxo
$\mathrm{K}_{\mathrm{a}}$
- Coeficiente de empuxo ativo
$\mathrm{K}_{\mathrm{O}}$
- Coeficiente de empuxo em repouso
$\mathrm{K}_{\mathrm{O}(\mathrm{NC})}$
- Coeficiente de empuxo em repouso para solos normalmente adensados
$\mathrm{K}_{\mathrm{p}}$
- Coeficiente de empuxo passivo
$\mathrm{K}_{\mathrm{u}}$
- Coeficiente de arrancamento
L
- Medida de comprimento (m) 
L crit. - Comprimento crítico, a partir do qual a tensão vertical permanece constante $(\mathrm{m})$

$\mathrm{Mc},(\mathrm{M} \phi+\mathrm{M} \gamma)$ e Mq - Coeficientes adimensionais de coesão, atrito e gravidade, e sobrecarga

$\mathrm{Nc}$ e Nq

- Fatores de capacidade de carga para fundações comprimidas

OCR - Índice de pré-adensamento

$\mathrm{P}_{\mathrm{f}} \quad$ - Peso próprio da fundação $(\mathrm{kN})$

$\mathrm{P}_{\mathrm{f} \phi}$

- Termo de atrito $(\mathrm{kN})$

$\mathrm{P}_{\mathrm{fc}}$

- Termo de coesão $(\mathrm{kN})$

$\mathrm{P}_{\mathrm{lu}}$

- Carga última lateral $(\mathrm{kN})$

$\mathrm{P}_{\text {máx }}$

- Carga máxima medida na prova de carga $(\mathrm{kN})$

$\mathrm{P}_{\mathrm{q}}$

- Termo de sobrecarga $(\mathrm{kN})$

$\mathrm{P}_{\gamma}$

- Termo de gravidade $(\mathrm{kN})$

$\mathrm{P}_{\mathrm{u}}$

- Carga última da estaca $(\mathrm{kN})$

$\mathrm{P}_{\mathrm{S}}$

- Peso do solo contido no interior da superficie de ruptura $(\mathrm{kN})$

$\mathrm{R}$

- Raio (m)

$\mathrm{R}_{\mathrm{C}}$

- Rugosidade da face do concreto (mm)

$\mathrm{R}_{\mathrm{R}}$

- Rugosidade relativa da interface (mm)

$\mathrm{RS}_{\mathrm{S}}$

- Rugosidade da face do solo (mm)

- Fator de forma 
w

z

$\alpha$

$\alpha$

$\alpha_{\mathrm{T}}$

$\gamma$

$\delta$

$\eta$

$\phi$

$\lambda$

vp

$\sigma_{\mathrm{h}}$

$\sigma_{\mathrm{vm}}$

$\sigma_{\mathrm{vm}}^{\prime}$

$\tau$
- Teor de umidade do solo (\%)

- Profundidade (m)

- Inclin. da superf. de ruptura no método do tronco de cone $\left({ }^{\circ}\right)$

- Fator de adesão

- Coeficiente de redução da tensão vertical

- Peso específico do solo $\left(\mathrm{kN} / \mathrm{m}^{3}\right)$

- Ângulo de atrito solo-estaca $\left({ }^{\circ}\right)$

- Coeficiente adimensional de compressibilidade

- Ângulo de atrito (em termos de tensão total) $\left({ }^{\circ}\right)$

-Inclinação da superficie de ruptura no método de Grenoble $\left({ }^{\circ}\right)$

- Coeficiente de Poisson da fundação

- Tensão horizontal total $(\mathrm{kPa})$

- Tensão vertical total devido ao peso do solo $(\mathrm{kPa})$

- Tensão vertical efetiva média, devido ao peso do solo $(\mathrm{kPa})$

- Tensões cisalh. mobiliz. ao longo da superf. de ruptura $(\mathrm{kPa})$ 


\section{RESUMO}

CAMPELO, N. Comportamento de estacas sujeitas a esforços de tração, em solo colapsível, São Carlos, 1994. 139 p. Dissertação (Mestrado). Escola de Engenharia de São Carlos, Universidade de São Paulo.

Este trabalho aborda uma análise comparativa dos resultados obtidos em provas de carga à tração, com os diversos métodos de previsão de carga última de estacas tracionadas. Os ensaios foram realizados no campo experimental de fundações do Departamento de Geotecnia da USP/São Carlos, sobre estacas apiloadas, escavadas a trado helicoidal e do tipo Strauss, com diâmetros de 20 a $32 \mathrm{~cm}$, e comprimentos de 6 e $9 \mathrm{~m}$. Observou-se que os métodos que consideram a ruptura na interface soloestaca são os que conduzem a resultados mais satisfatórios de previsão.

Ademais, estudou-se a colapsibilidade da ligação solo-estaca, uma vez que as estacas analisadas têm seu fuste embutido em solo de estrutura comprovadamente colapsível. Para tanto, realizaram-se as provas de carga primeiramente com o solo em estado natural e, posteriomente, inundado por $48 \mathrm{~h}$, na carga de trabalho. Constatou-se o colapso da ligação solo-estaca nas cinco estacas, sendo que em três delas - duas escavadas e uma apiloada -, o colapso deu-se na carga de trabalho, com tempos de inundação inferiores a $48 \mathrm{~h}$; nas outras duas estacas, após $48 \mathrm{~h}$ de inundação, prossegui-se normalmente com os incrementos de carga, ocorrendo o colapso para 60 e $78 \%$ das cargas respectivas de ruptura.

Palavras-Chave: Estacas; provas de carga; tração; solo colapsivel 


\begin{abstract}
CAMPELO, N. Behavior of piles submitted to axial tensile forces in collapsible soil, São Carlos, 1994, 139 p. Dissertação (Mestrado) - Escola de Engenharia de São Carlos, Universidade de São Paulo.
\end{abstract}

This dissertation deals with an analysis by comparison of results obtained with piles submitted to axial uplift foreces using several prediction methods of ultimate loads. The pile tests were performed in the Experimental Site of the Departament of Geotechnical Engineering of USP/São Carlos, on bored, hammed and Strauss pile types, with diameters varying from 0,20 to $0,32 \mathrm{~m}$ and 6 to $9 \mathrm{~m}$ long. It was observed that the methods that took into account the pile-soil interface failure yelded better results.

Moreover, the pile-soil interface colapsibility was analyzed, once the shaft of the studied piles were embedded in soil whose structure are truly collapsible. For this, pile testings were performed both in the natural soil conditions and soaked during 48 $\mathrm{h}$ for working load. Collapse was observed in the pile-soil interface in five piles. For three of them (two of which were bored and one hammed) the failure took place with working loads under $48 \mathrm{~h}$ soaking time; in two others, the failure, occured after $48 \mathrm{~h}$ soaking time with loads equivalents to $60 \%$ and $78 \%$ of natural soil's ultimate loads, respectively.

Keywords: Pile; pile test; tensile; colapsible soil. 


\section{Capítulo 1}

\section{INTRODUÇÃO}

De acordo com CHATTOPHADYAY \& PISE (1986) muitas obras em Engenharia têm suas fundações submetidas a esforços de tração. Entre essas obras, poder-se-ia citar as plataformas off-shore, torres de linhas de transmissão, portos, muros de arrimo, chaminés de indústrias, etc.

Dentro de uma metodologia teórica nos moldes do conhecimento geotécnico atual do solo, com todas suas nuances, os métodos de previsão de cálculo de capacidade de carga de fundações tracionadas são recentes, provindos, na sua maioria, a partir da década de 1960. Esses métodos nasceram de pesquisas em modelos, em fundações rasas e profundas, em areias e argilas, ou para solo genérico. A partir daí, em vários paises do mundo, procurou-se aferir o grau de confiança dos métodos propostos, através de provas de carga.

No Brasil, os primeiros estudos de fundações tracionadas remontam aos apresentados por NÁPOLES NETO (1958) e VELLOSO (1959). O primeiro autor analisou o caso de uma prova de carga em estaca metálica, para fundações de ponte, constituida de dois perfis duplo $\mathrm{T}$, de $32 \mathrm{~m}$ de comprimento. Ele considerou que o atrito lateral à compressão fosse o mesmo que à tração, e, a partir dai, determinou os parâmetros geotécnicos do solo. O segundo apresentou vários resultados de provas de carga à tração em estacas Franki, de vários países, comentando que as mesmas suportaram grandes esforços de arrancamento, notando-se que, nos casos em que o ensaio fora levado até a ruptura, esta ocorreu sempre na armação, sem que pudesse arrancar a estaca.

Modernamente, há em fundações profundas, vários estudos de tubulões, conforme os trabalhos de PALADINO (1975, 85), DANZIGER (1983), e 
ORLANDO (1985). Entretanto, fundações em estacas escavadas começaram a ser estudadas a partir dos trabalhos de MELO (1982a,b), MONTEIRO (1985), MATOS (1989), CARVALHO \& SOUZA (1990) e CARVALHO (1991). No entanto, o estudo do efeito da inundação na capacidade de carga de estacas tracionadas iniciouse somente com os trabalhos de CARVALHO \& SOUZA (1990), que realizaram provas de carga em estacas escavadas com o solo em estado natural e, posteriormente, inundado, no campo experimental da UNESP/Ilha Solteira, SP. Posteriormente, CARVALHO \& ALBUQUERQUE (1994) ensaiaram estacas escavadas, sendo uma delas instrumentada, no mesmo local.

Em estacas-raiz, apresentaram-se os estudos de CARVALHO et al. (1991) e de AZEVEDO (1991).

Atualmente, há a tendência de instrumentar-se as fundações profundas, à tração e à compressão, para a determinação da mobilização de resistência lateral e de ponta, bem como a transferência de carga ao longo do fuste das mesmas.

Nesse sentido, CINTRA et al. (1991) relataram que em São Carlos, com o fortalecimento da pós-graduação na área de fundações, o Departamento de Geotecnia da USP/São Carlos veio por bem instalar um campo experimental, no ano de 1988, localizado no campus universitário, contando inicialmente com uma área de $400 \mathrm{~m}^{2}$. Nesta fase, foram ensaiadas estacas escavadas e do tipo raiz, isoladas e instrumentadas. Posteriormente, em 1991, o campo fora ampliado em $200 \mathrm{~m}^{2}$, passando-se a estudar estacas isoladas escavadas e apiloadas, de pequeno diâmetro, sujeitas a esforços de tração e compressão, bem como grupos instrumentados de estacas escavadas.

O trabalho ora apresentado faz parte da fase de ampliação do campo experimental, englobando o estudo da comparação entre os métodos teóricos de previsão de carga última à tração e os resultados de provas de carga em estacas tracionadas escavadas, apiloadas e do tipo Strauss. Considerando que grande área do Interior paulista é coberto por uma camada superficial, constituída de sedimento cenozóico, e que em várias regiões comprovou-se ser colapsível, quando inundado e carregado, inclusive na cidade de São Carlos (VILAR, 1979), estudou-se a colapsibilidade da ligação solo-estaca, realizando-se provas de carga com o solo em seu estado natural e inundado por tempo máximo de $48 \mathrm{~h}$, na carga de trabalho. 
Quanto à estaca Strauss analisada, cabe registrar que o ensaio em umidade natural foi realizado pelo Prof. DAVID DE CARVALHO, da Universidade de Campinas (UNICAMP). 


\section{Capítulo 2}

\section{REVISÃO BIBLIOGRÁFICA}

\subsection{Colapsibilidade de Solos}

\subsubsection{Caracterização}

VILAR (1979) afirmou que existem alguns tipos de solos que apresentam a peculiaridade de sofrer uma diminuição brusca de volume, e, por conseguinte, do indice de vazios, seja por um carregamento externo superior a um valor limite, seja pelo aumento do conteúdo de água em seus vazios. A redução dar-se-ia apenas pelo peso próprio do solo, ou ainda, por uma ação combinada desses dois mecanismos.

VILAR (1979) também relatou que diversos autores têm sugerido denominações distintas para descrever esse fenômeno, tais como colapso (DUDLEY, 1970), solo colapsivel (FEDA, 1966; DUDLEY, 1970; ARMAN \& THORNTON, 1973; NUÑES, 1975), subsidência (FEDA, 1966; GIBBS \& BARA, 1967); hidrocompactação e hidroconsolidação (DUDLEY, 1970).

Neste trabalho, será utilizado o termo "solo colapsível", para designar os solos em que ocorrem tal fenômeno. Segundo BENVENUTO (1982), um fator característico da ocorrência de deformações volumétricas, causadas pelo aumento do grau de saturação do solo, é a velocidade com que se dá o fenômeno, resultando em tempos quase sempre bastante curtos para a quebra das ligações entre as partículas, estando a velocidade dos recalques oriundos destas deformações, relacionada com a velocidade de umedecimento do solo. 
De acordo com DUDLEY (1970) e NUÑES (1975), um arranjo entre partículas que forma uma estrutura porosa, com elevado índice de vazios e um teor de umidade menor que o necessário para completa saturação, são dois requisitos necessários para configurar um solo com grande potencialidade de ser colapsível. $\mathrm{O}$ colapso se realiza quando as partículas, constituintes de uma estrutura altamente porosa, estão em um pseudo-equilíbrio, à custa de uma resistência adicional momentânea, produzida por pressões capilares (induzindo a pressões de contato entre partículas), por forças eletromagnéticas de superficie (osmose, Van der Walls e atração molecular) e pela eventual existência de agentes cimentantes como carbonatos, óxidos de ferro, etc.

TERZAGHI (1973) citou que em areias úmidas, a tensão superficial ao longo da linha de contato (menisco capilar) entre sólido e água produz a chamada pressão de contato entre os grãos, pressionando uns contra os outros, resultando em uma resistência de atrito similar à coesão das argilas. VARGAS (1978) relatou que essa resistência adicional, denominada de coesão aparente, aumenta a tal ponto a resistência ao cisalhamento da areia, que taludes verticais de altura elevada permanecem estáveis, sem suporte lateral algum.

De acordo com DUDLEY (1970), a pressão capilar desponta como o principal fator de resistência adicional momentânea dos solos colapsíveis. Não obstante, TERZAGHI (1973) afirmou que se se submerge o solo, elimina-se a tensão superficial, desaparece a pressão de contato e cessa-se a coesão aparente. Segundo VARGAS (1978), isso deve-se ao aumento da espessura do filme d'água entre os grãos do solo, pois a pressão capilar é inversamente proporcional ao raio de curvatura do menisco capilar.

Quanto às forças eletromagnéticas de superficie, TERZAGHI (1973) citou que estas são predominantes, em relação à força gravitacional, para partículas de pequenas dimensões. Na presença de água com certas concentrações de eletrólitos, as superficies de algumas das partículas atraem os cátions, adsorvendo-os, de tal maneira que estas podem atrair outras partículas, acumulando-se em flocos, e assim, ao chegarem a um certo tamanho, sedimentam-se por ação da gravidade. Como a maioria dos sedimentos também contém partículas mais grossas, estas contribuem de uma maneira significativa para a formação de variadas e complexas estruturas. 
DUDLEY (1970) afirmou que a adição de água ao solo, torna mais espesso o filme de água adsorvida existente entre as particulas, tendendo a distanciá-las. Portanto, as forças atrativas diminuem, pois as forças de superficie decaem rapidamente com a distância, reduzindo a resistência desse solo, o que favorece o colapso da estrutura.

Finalmente, o terceiro fator responsável pelo aumento temporário da resistência do solo é a presença de um agente cimentante. Os grãos são mantidos em sua posição, proporcionando uma estrutura razoavelmente densa. O modo como a ligação entre as partículas começa a enfraquecer é bastante distinta, dependendo da natureza das substâncias dissolvidas na água que infiltra no solo e da solubilidade do cimento presente, entre outros (REGINATTO \& FERRERO, 1973).

Para comprovar esse fato, ALWAIL et al. (1992) concluíram que, em solos areno-siltosos compactados, o fator mais importante na influência da colapsibilidade é a presença de argila, como um agente cimentante, e para alguns casos, a forma dos grãos de silte. Grãos de silte angular e em flocos "empacotam-se" em uma estrutura mais aberta que grãos de silte arredondados ou sub-arredondados. Solos com uma estrutura mais aberta terá um maior potencial de colapso, sob inundação. Isto é tanto verdade, quanto maior a porcentagem de silte no solo ou quanto maior a estrutura instável em areias.

\subsection{2. Áreas de ocorrência}

HOLTZ \& GIBBS (1951) relataram que os solos colapsíveis já mereciam estudo desde 1898, quando discutia-se o efeito da capilaridade na coesão aparente dos mesmos.

Segundo FLINT (1971), apud BOWLES (1988), o loesse é o solo colapsível predominante e o mais extenso, cobrindo cerca de $17 \%$ da área territorial dos Estados Unidos e Europa, incluindo algumas partes da França, Alemanha e Europa Oriental. Próximo de $15 \%$ da superficie da ex-URSS apresentam depósitos loésicos, bem como grande regiões da China. Muito pouco loesse é encontrado no Canadá e nenhum na Austrália ou África (mas ambas possuem outros depósitos eólicos ). 
SOWERS \& SOWERS (1972) citaram que o vento é capaz de levantar e transportar partículas menores que a areia fina, principalmente siltes secos nas regiões áridas, pois os solos coesivos ou úmidos resistem à erosão eólica. Se existem fortes correntes de ar, o silte pode ser transportado a muitos quilômetros de distância, acumulando-se em terras semi-áridas cobertas de ervas, que margeiam as regiões áridas. Os depósitos se formam lentamente, e, por conseguinte, o crescimento de ervas segue o passo da deposição. O resultado é uma grande porosidade vertical e uma exfoliação vertical, combinadas com uma estrutura extremamente solta; estes solos chamam-se loesses. A maior parte dos solos de loesse é duro devido a deposição de carbonato de cálcio e óxido de ferro que revestem as antigas cavidades de antigas raizes, mas tornam-se moles quando se saturam. Os loesses caracterizamse pelo tamanho uniforme de seus grãos, sua cor amarelo castanho e sua pronunciada exfoliação vertical. Nas margens das correntes, dos barrancos e dos cortes de loesse, os taludes são quase verticais devido à exfoliação e à grande permeabilidade vertical, que permite uma rápida saturação com as chuvas e, conseqüentemente, o desprendimento do solo em planos verticais.

VILAR (1979) citou o fato de que o fenomeno de colapsibilidade tem sido constatado também em sedimentos aluviais (DUDLEY, 1970), coluviais (HOLTZ \& HILF, 1961), eólicos (JENNINGS \& KNIGHT, 1957), solos residuais (BRINK \& KANTEY, 1961), aterros (NUÑES, 1975) e até em argilas compactadas em laboratório, com umidade abaixo da ótima, relacionado à estrutura floculada resultante, donde conclui-se que a colapsibilidade não está associada apenas a regiões com climas áridos e semi-áridos, pois, citando-se apenas o caso do Brasil, o fenômeno ocorre em pleno clima tropical úmido.

A constatação e o estudo da colapsibilidade, no Brasil, remonta à década de 1960, quando começou-se a construção das grandes Barragens na região Centro-Sul, não obstante VARGAS (1953) ter chamado a atenção, àquela época, sobre o comportamento dos solos residuais dessa região, destacando sua elevada porosidade e o fato de apresentarem-se insaturadas e as conseqüências nefastas que os mesmos propiciavam às fundações das obras de Engenharia.

Atualmente, têm-se realizado vários estudos, em diversas regiões do País, sobre a colapsibilidade de solos, tanto em laboratório, quanto em campo. No Estado de São Paulo, no tocante aos ensaios de caracterização e quantificação desse fenômeno, em laboratório e em campo, há os trabalhos de VILAR (1979), CINTRA 
(1993) e TEIXEIRA (1993), em São Carlos; LOBO (1991) e AGNELLI (1992), em Bauru, entre muitos outros.

\subsection{Métodos de Previsão da Capacidade de Carga de Fundações à Tração}

\subsubsection{Considerações iniciais}

Apresentam-se, a seguir, os métodos de previsão de carga última de fundações tracionadas, que foram utilizados na presente pesquisa. Entretanto, há na literatura internacional muitos outros métodos, alguns consagrados e que não foram aqui abordados por não se enquadrarem no estudo específico de fundações em estacas, ou no tipo específico do solo em estudo, ou pela própria limitação teórica do método.

Entre eles, poder-se-ia citar:

a) Método de BALLA (1961): Apesar de ser o primeiro método a introduzir explanação teórica compativel com o conhecimento da Mecânica dos Solos moderna, fora generalizado apenas para fundações rasas, de base alargada, em forma de sapatas circulares;

b) Método da Universidade de Duke (ou de VÉSIC, 1969,71): Não obstante apoiar-se nos trabalhos de vários autores, ao longo de vários anos, e ter um bom refinamento teórico, originou-se do estudo da carga última à tração de objetos enterrados, no fundo do mar, em forma de placas circulares ou retangulares infinitas, nas quais os esforços de tração são transmitidos por meios de cabo de aço. Ademais, não mostra como calcular a capacidade de carga de fundações profundas e, de acordo com DANZIGER (1983), não é aplicável para fundações com relação entre comprimento e diâmetro (L/D) maior que 5;

c) Método de TRAN-VON-NHIEM (1971): Desenvolvido para estacas cilindricas ou de seção retangular, verticais ou inclinadas, embutidas em solos compactados ou não. Contudo, apresenta ábacos com parâmetros de previsão de carga última para valores de L/D até 10 , muito abaixo daqueles em uso neste trabalho; 
d) Método de CHATTOPADHYAY \& PISE (1986): Apresenta desenvolvimento teórico semelhante ao de BALLA (1961), entretanto, não oferece ábacos para a determinação dos parâmetros envolvidos no método de cálculo. A resolução da equação geral de arrancamento é complexa, necessitando, então, de métodos numéricos de integração, o que dificulta a utilização deste método;

e) Método de MELO (1982a): Método iterativo de previsão para estacas escavadas em argilas, submetidas ao arrancamento. $\mathrm{O}$ método aborda também a transferência de carga e deslocamentos, tanto do topo, quanto de qualquer ponto ao longo do fuste da estaca. Parte do método de COYLE \& REESE (1966) e pressupõe que a ruptura ocorre em um plano vertical, não necessariamente na interface soloestaca.

\subsubsection{O método do tronco de cone (ou de pirâmide)}

\subsubsection{Generalidades sobre o método}

É o método mais antigo empregado no cálculo da resistência ao arrancamento de fundações. DANZIGER (1983) citou que já em 1916 este método fora apresentado em bibliografia internacional, utilizado no dimensionamento de fundações de torres de linha de transmissão, nos Estados Unidos, podendo até mesmo existir publicações mais antigas relacionadas a ele.

A capacidade de carga à tração é obtida pelo somatório dos pesos da fundação e do solo contido num tronco de cone - ou de pirâmide, cuja geratriz forma um ângulo $\alpha$ com a vertical e cuja base menor corresponde à base da fundação (circular ou retangular) e base maior, à interseção da superficie lateral com o nivel do terreno, conforme a Figura 2.1.

A carga última à tração de uma fundação é dada por:

$$
P_{u}=P_{f}+P_{s}
$$

onde:

$\mathrm{P}_{\mathrm{f}}=$ peso da fundação; 
$\mathrm{P}_{\mathrm{S}}=$ peso do solo contido no tronco de cone (base circular) ou tronco de pirâmide (retangular ou quadrada), descontando-se o peso próprio da fundação.

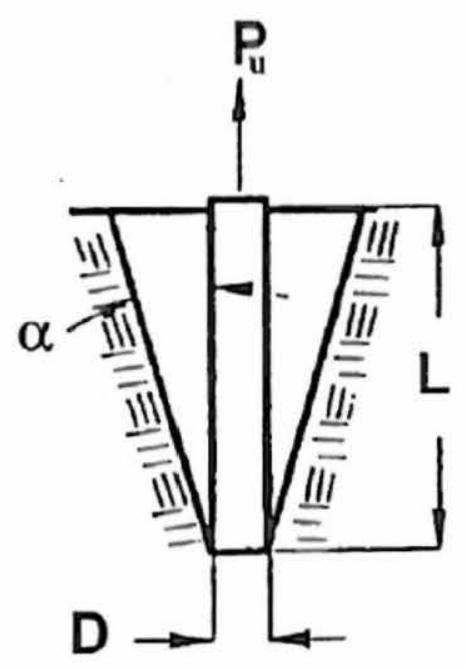

FIGURA 2.1 - Método do Tronco de Cone (ou de Pirâmide) Aplicado a Estacas.

Para fundações de base circular de diâmetro (D) e comprimento (L), a carga última à tração $\left(\mathrm{P}_{\mathrm{u}}\right)$ é:

$$
\mathrm{P}_{\mathrm{u}}=\mathrm{P}_{\mathrm{f}}+\mathrm{C}_{1} \mathrm{~L}+\mathrm{C}_{2} \mathrm{~L}^{2}+\mathrm{C}_{3} \mathrm{~L}^{3}
$$

onde:

$$
\begin{aligned}
& C_{1}=\pi / 4 D^{2} \gamma ; \\
& C_{2}=\pi / 2 D \gamma \operatorname{tg} \alpha ; \\
& C_{3}=\pi / 3 \gamma \operatorname{tg}^{2} \alpha .
\end{aligned}
$$

Conhecendo-se o ângulo de inclinação da geratriz da superficie do cone com a vertical e o peso específico do solo, determina-se a carga última à tração. Segundo ORLANDO (1985), o ângulo $\alpha$ é comumente denominado ângulo de mobilização do tronco de cone. Este método é bastante empírico, pois, sendo muito antigo, não emprega conceitos modernos da Mecânica dos Solos, por ser até mesmo anterior a esta. 
DOWNS \& CHIEURZZI (1966) apud ORLANDO (1985), sugeriram adotar a inclinação da geratriz do tronco de cone com a vertical $(\alpha)$, igual ao ângulo de atrito interno do solo $(\phi)$ e WIGGINS (1969) concordou com esses autores, mas somente para fundações com base alargada, em solos granulares $\left(\alpha=\phi \cong 30^{\circ}\right)$.

BALLA (1961), BAKER \& KONDNER (1965), ESQUIVEL-DIAZ (1967) e ALI (1968) também consideraram $\alpha$ como o ângulo de atrito interno do solo (apud DANZIGER, 1983). Entretanto, PALADINO (1972, 75, 85) e DANZIGER (1983, 85) afirmaram que $\alpha$ varia com as características do solo, tais como a coesão, o ângulo de atrito e o peso específico, com a profundidade e com as peculiaridades da fundação - tipo de base, modo de instalação, etc., porém, um valor mais rigoroso de $\alpha$ só pode ser determinado por prova de carga em escala natural e para o mesmo tipo de solo.

Pela equação (2.1b) vê-se que a resistência ao arrancamento cresce muito com a profundidade, o que é falso. Na verdade, $\alpha$ tende a diminuir com o aumento da profundidade da fundação, e mesmo que o solo permaneça o mesmo, fundações próximas podem apresentar valores de $\alpha$ bem distintos (DANZIGER, $1983 \mathrm{e}$ ORLANDO, 1985). Entretanto, MATOS (1989) e CARVALHO (1991) encontraram valores de $\alpha$ bem próximos, em estacas brocas e escavadas, respectivamente.

DANZIGER \& PEREIRA PINTO (1979b) variaram o ângulo $\alpha$ entre $15^{\circ} \mathrm{e}$ $30^{\circ}$ (valores usualmente tomados na prática, quando não se dispõe de provas de carga, segundo os autores), cada $5^{\circ}$, determinaram as respectivas cargas de ruptura teóricas e compararam-nas com as obtidas em provas de carga, por eles executadas, chegando-se à seguinte conclusão: para $\alpha=15^{\circ}$, encontraram até $51 \%$ de erro contra a economia; para $\alpha=30^{\circ}$, até $178 \%$ de erro contra a segurança, para tubulões; para sapatas, os erros foram menores. Então este método pode conduzir tanto a resultados conservadores (placas e sapatas), quanto contrários à segurança (tubulões e estacas), o que foi confirmado por ADAMS \& HAYES (1967).

DANZIGER (1984) relatou que este método, aplicado com os valores de parâmetros constantes nas especificações de FURNAS, forneceu resultados cinco vezes menores, em média, que aqueles obtidos em provas de carga. PALADINO (1972) sugeriu adotar o ângulo $\alpha$ entre $10^{\circ}$ e $25^{\circ}$, quando não se possui dados de provas de carga. Baseando-se em resultados obtidos em provas de carga em Bauru (SP), encontrou valores concentrados na faixa de $11^{\circ}$ a $18^{\circ}$. 
Apesar de apresentar resultados não muito confiáveis, este método é o mais utilizado no Brasil, no projeto de torres de linhas de transmissão (DANZIGER, 1983; ASHCAR, 1985; PALADINO, 1985 e MEDEIROS, 1985).

\subsubsection{Vantagens na aplicação do método}

- É de aplicação bastante fácil;

- Quando baseado em provas de carga no mesmo tipo de solo e com características semelhantes de fundação, podem conduzir a bons resultados (ORLANDO, 1985), embora DANZIGER (1983) afirmasse que, mesmo nesse caso, pode haver certas discrepâncias, devido o valor de $\alpha$ a se condiderar.

\subsubsection{Desvantagens na aplicação do método}

- Sendo bastante antigo, não explica o fenômeno da ruptura à luz dos conceitos da Mecânica dos Solos;

- Não leva em conta a possivel heterogeneidade de camadas do solo;

- Não faz distinção entre fundações rasas e profundas;

- Como o valor exato de $\alpha$ só é conhecido a posteriori, através de resultados de provas de carga, não faz sentido em pensar-se em um método de "previsão" de capacidade de carga, sem que se tenha os valores dos parâmetros a priori, pois, ao invés de se ter uma "previsão", passa-se a ter uma "comprovação";

- Não considera nenhuma parcela de resistência devida às tensões cisalhantes mobilizadas ao longo da superficie de ruptura, mas somente à parcelas de pesos;

- Não há condições de correlacionar o ângulo $\alpha$ com parâmetros geométricos (da fundação) e geotécnicos (do solo), em virtude do grande número de fatores envolvidos na sua determinação (DANZIGER, 1983, 85), não obstante PALADINO (1985) tenha tentado correlacionar o método do tronco de cone com o do cilindro de atrito. 


\subsubsection{O método do cilindro de atrito}

\subsubsection{Generalidades}

É um método que enfoca a aderência ou o atrito mobilizados ao longo da superficie de ruptura, na forma de um cilindro ou prisma, sendo a base igual à da fundação (se circular ou retangular) e estendendo-se verticalmente até o nível do terreno. Talvez um dos primeiros pesquisadores a abordar este método tenha sido KILLER (1953).

A resistência ao arrancamento é, então, o somatório do peso próprio da fundação, do solo contido no interior do cilindro ou prisma e da força de aderência ou de atrito ao longo da superficie de ruptura, como mostrado na Figura. 2.2.

Desta forma, a capacidade de carga à tração $\left(\mathrm{P}_{\mathrm{u}}\right)$ é:

$$
P_{u}=P_{I_{u}}+P_{s}+P_{f}
$$

onde:

$\mathrm{P}_{\mathrm{S}}=$ peso do solo contido no cilindro ou prisma, descontando-se $\mathrm{P}_{\mathrm{f}}$;

$\mathrm{P}_{\mathrm{lu}}=$ resistência lateral última ao longo da superficie de ruptura.

Obviamente, para estacas ou tubulões sem base alargada, o peso do solo contido no interior do cilindro ou prisma é nulo.

Segundo ADAMS \& RADHAKRISHNA (1971), MEYERHOF (1973), BARATA, PACHECO \& DANZIGER (1978) e DANZIGER (1983) a suposição de superficie cilíndrica no contato solo-fundação, para tubulões sem base alargada ou estacas, aproxima-se, em geral, do que se observa na prática. Para fundações de bases alargadas, a suposta superficie de ruptura cilindrica ou prismática, de acordo com a base da fundação, pode ser verificada somente para areias fofas ou argilas plásticas, à pequenas profundidades (MEYERHOF \& ADAMS, 1968). 


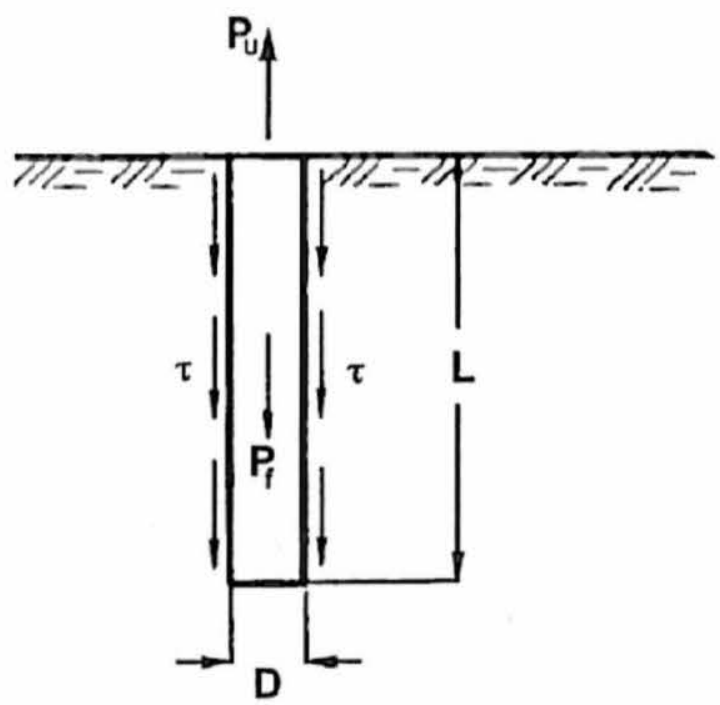

FIGURA 2.2 - O Método do Cilindro de Atrito Aplicado a Estacas.

Para estacas ou tubulões sem base alargada, considerando a superficie de ruptura como cilíndrica e ocorrendo no contato solo-estaca, o cálculo de capacidade de carga à tração é o apresentado pela Toria da Resistência Lateral, substituindo-se a coesão do solo pela adesão estaca-solo e o ângulo de atrito do solo pelo ângulo de atrito estaca-solo. No ítem 2.2.8 deste capitulo será detalhada essa teoria. Segundo KILLER (1953), este método é melhor empregado para argilas, sendo a geratriz tanto mais vertical, quanto menos rija ela se encontra.

\subsubsection{Vantagens}

- Considera a parcela de resistência mobilizada ao longo da superficie de ruptura;

- Para o caso de estacas ou tubulões sem base alargada, de profundidade relativamente elevada, DANZIGER (1983), ORLANDO (1985), MATOS (1989) e CARVALHO (1991) concluiram que o modelo de ruptura mais compatível com a realidade experimental é o que considera o desenvolvimento de uma superficie de ruptura cilindrica pela interface solo-estaca (teoria da resistência lateral). 


\subsubsection{Desvantagens}

- A superficie de ruptura é admitida cilíndrica ou prismática, o que depende das características da fundação e do solo; portanto, melhor seria se pudesse ser observada, pelo menos teoricamente;

- Dificuldades no cálculo exato da adesão ao longo do fuste;

- Não faz distinção entre camadas heterogêneas do terreno;

- Não faz distinção entre fundações rasas e profundas

\subsubsection{O método de Meyerhof \& Adams}

\subsubsection{Generalidades}

MEYERHOF \& ADAMS (1968) desenvolveram um método simplificado para estimativa da capacidade de carga de fundações, submetidas a esforços de arrancamento, a partir de resultados de ensaios em modelos, em pequenos discos metálicos, de diâmetros variando de $2,5 \mathrm{~cm}$ a $10 \mathrm{~cm}$, em várias profundidades, conduzidos por diversos pesquisadores no Canadá, cujas observações foram publicadas em distintos trabalhos.

As areias apresentavam-se graduadas e bem graduadas, em estado fofo e compacto. Para areias compactas, em pequena profundidade, observaram uma superficie de ruptura em forma de arco, partindo do canto da placa e estendendo-se até o nivel do terreno; para grande profundidade, notaram superficie de ruptura inicialmente curva, tornando-se vertical até o nível do terreno. Entretanto, para ambos os casos encontraram capacidade de carga aumentando fortemente com a profundidade.

Com relação às areias fofas, com fundação rasa, a superficie de ruptura apresentou-se vertical, atingindo o nivel do terreno; para fundações profundas, a superficie de ruptura continuava vertical, embora não atingisse a superficie do terreno. Nestas areias, a capacidade de carga aumentou de forma praticamente linear com a profundidade. 
Nas areias bem graduadas, as cargas de ruptura observadas foram maiores que para as de graduação uniforme. MEYERHOF \& ADAMS (1968) concluiram, então, que para a areia compacta, houve uma mobilização da resistência ao cisalhamento em uma superficie muito maior do que para a areia fofa.

Em argilas, para fundação rasa, submetida a esforços de arrancamento, houve o surgimento de fendas, devido às tensões de tração provocadas pela flexão do solo, bem como de pressões neutras negativas, abaixo e acima da fundação. Em contrapartida, para fundação profunda, o peso do solo acima desta tende a impedir a flexão do solo sobre a mesma. Essas argilas possuiam consistência variando de mole a rija, em condições amolgadas e saturadas.

Verificou-se que tanto na argila mole, como na rija, a capacidade de carga aumentara com a profundidade até um valor constante. Os deslocamentos nas argilas foram superiores aos da areia, antes da ruptura. Houve também uma nítida formação de uma superficie de ruptura, principalmente a pequena profundidade. Os autores fazem uma distinção entre fundações rasas e profundas, não obstante a teoria primeiramente ter abordado as fundações corridas e posteriormente, as circulares e retangulares, em areias e argilas (Figura 2.3).

MEYERHOF \& ADAMS (1968) chegaram às seguintes equações, para fundações circulares:

a) Pequenas profundidades $(\mathrm{L} \leq \mathrm{H})$ :

Quando a carga de ruptura é atingida, uma massa de solo com a forma aproximada de um tronco de pirâmide é levantada e a superficie de ruptura atinge o nivel do terreno. A capacidade de carga, fica, então, determinada pela soma do peso com as parcelas de resistência ao cisalhamento mobilizada:

$$
\mathrm{u}=\pi \mathrm{cDL}+\mathrm{s} \pi / 2 \gamma \mathrm{Dz} z^{2} \mathrm{~K}_{\mathrm{u}} \operatorname{tg} \phi+\mathrm{P}_{\mathrm{S}}+\mathrm{P}_{\mathrm{f}}
$$

onde:

$\mathrm{s}=$ fator de forma que governa o empuxo passivo em uma parede cilíndrica convexa dado por $\mathrm{s}=1+\mathrm{m}$.(L/D), com um valor máximo de $1+\mathrm{m}$.(H/D); 


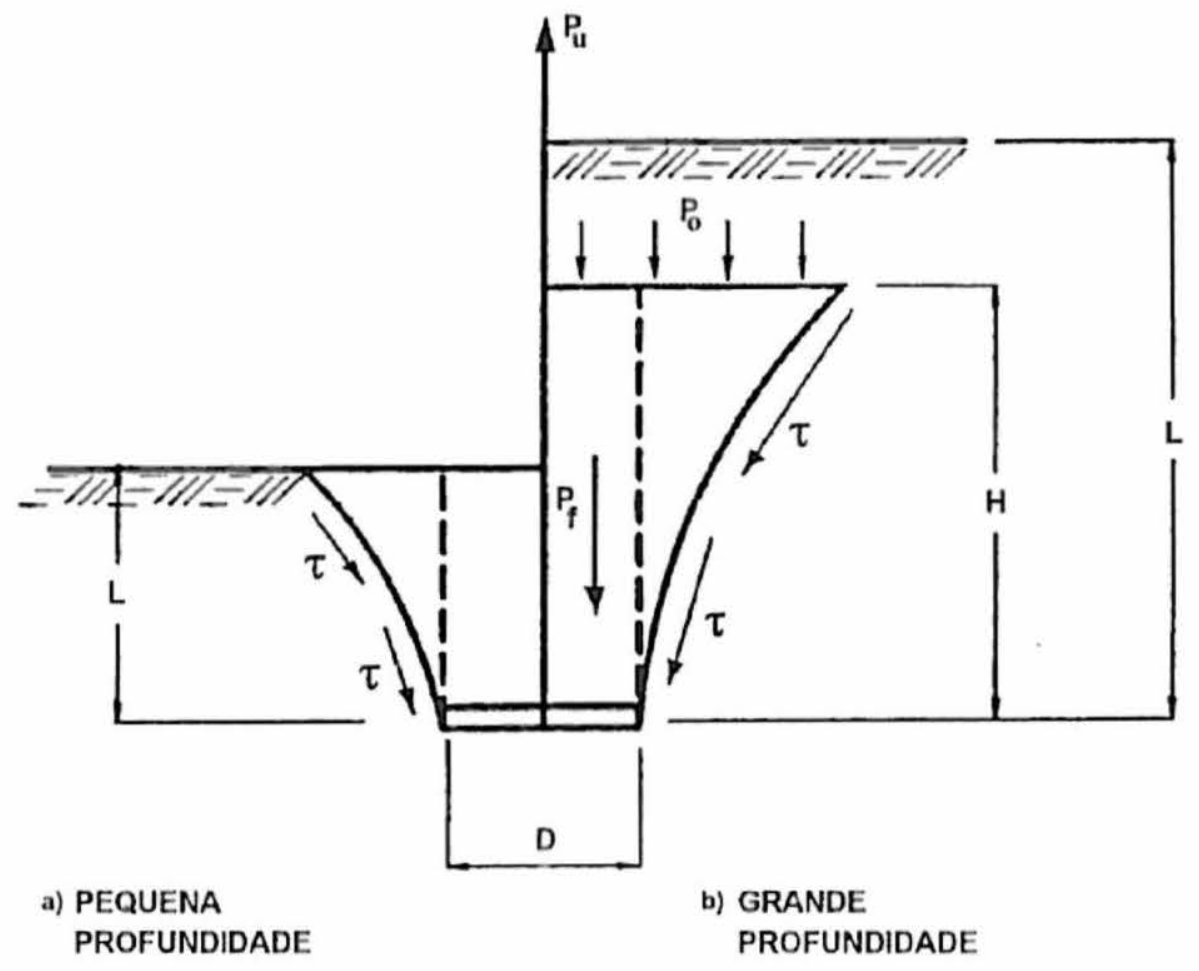

FIGURA 2.3 - Superficies de Ruptura em Fundações Corridas: (a) Rasas e (b) Profundas (MEYERHOF \& ADAMS, 1968).

$\mathrm{K}_{\mathrm{u}}=$ coeficiente de empuxo passivo nominal, à tração, correspondente ao plano vertical passando pelo bordo da fundação (aproximadamente 0,90 a 0,95 , para valores de $\phi$ entre $25^{\circ}$ e $40^{\circ}$ );

$\mathrm{m}=$ coeficiente que depende de $\phi$;

$\mathrm{P}_{\mathrm{S}}=$ peso do solo contido no cilindro acima da base, levantado na ruptura.

b) Grandes profundidades $(\mathrm{L}>\mathrm{H})$ :

Para fundações profundas, supõe-se que a superficie de ruptura seja inclinada em relação à vertical, mas que devido à compressibilidade e deformabilidade do solo acima da base da fundação, essa superfície não atinge a superficie do terreno, mas somente uma altura $\mathrm{H}$, menor que a profundidade $\mathrm{L}$ da fundação, fato confirmado por RADHAKRISHNA \& ADAMS (1973). Considera-se que, acima da altura $\mathrm{H}$, atue uma sobrecarga, tal que $\mathrm{P}_{\mathrm{O}}=\gamma(\mathrm{L}-\mathrm{H})$.

Então a equação obtida é:

$$
\mathrm{u}=\pi \mathrm{cDH}+\mathrm{s} \pi / 2 \gamma \mathrm{D}(2 \mathrm{~L}-\mathrm{H}) \mathrm{K}_{\mathrm{u}} \operatorname{tg} \phi+\mathrm{P}_{\mathrm{s}}+\mathrm{P}_{\mathrm{f}}
$$


em que:

$\mathrm{H}=$ comprimento vertical limite da superficie de ruptura acima da base da fundação;

$P_{S}=0$ (estacas e tubulões sem base alargada)

MEYERHOF \& ADAMS (1968) apresentaram ainda um valor limite superior para a capacidade de carga à tração, que é dado pela soma da carga última da base da fundação com o atrito lateral de seu fuste:

$$
P_{u}=D\left(c N_{c}+\gamma L N_{q}\right)+A_{1} f_{s}+P_{s}+P_{f}
$$

onde:

$\mathrm{A}_{\mathrm{l}}=$ área lateral do fuste da fundação;

$\mathrm{f}_{\mathrm{S}}=$ atrito lateral unitário médio entre o solo e o fuste;

$\mathrm{N}_{\mathrm{c}}$ e $\mathrm{N}_{\mathrm{q}}=$ fatores de capacidade de carga para fundações à compressão, obtidos por MEYERHOF (1951).

Os valores de (H/D), s e m, obtidos por MEYERHOF \& ADAMS (1968), encontram-se na Tabela 2.1 .

TABELA 2.1 - Valores dos coeficientes m e limites máximos do fator de forma s, em função do ângulo de atrito interno e da profundidade relativa, segundo MEYERHOF \& ADAMS (1968).

\begin{tabular}{|c|c|c|c|c|c|c|c|}
\hline$\phi\left(^{\circ}\right)$ & 20 & 25 & 30 & 35 & 40 & 45 & 48 \\
\hline $\mathrm{H} / \mathrm{D}$ & 2,5 & 3 & 4 & 5 & 7 & 9 & 11 \\
\hline $\mathrm{m}$ & 0,05 & 0,10 & 0,15 & 0,25 & 0,35 & 0,50 & 0,60 \\
\hline $\mathrm{s}$ & 1,12 & 1,30 & 1,60 & 2,25 & 3,45 & 5,50 & 7,60 \\
\hline
\end{tabular}

RADHAKRISHNA \& ADAMS (1973) afirmaram que para fundações cilindricas, escavadas em argila dura fissurada, a teoria de MEYERHOF \& ADAMS (1968) superestimam a carga última ao arrancamento de longa duração, usando parâmetros de resistência de pico, mas utilizando-se parâmetros de resistência residual, há uma boa aproximação. 
DANZIGER (1983) encontrou resultados conservadores, para estacas e tubulões sem alargamento de base, com erros entre 17 a $34 \%$, que aumentavam com o aumento de L/D. Analogamente, observou-se a mesma ocorrência nos trabalhos de ORLANDO (1985), CARVALHO (1991) e MATOS (1989), não obstante este último autor encontrar resultados contra a segurança, utilizando-se parâmetros de resistência do solo determinados através de ensaios triaxiais efetivos de pico e residuais.

\subsubsection{Vantagens}

- É de fácil aplicação, precisando-se conhecer apenas o peso específico, a coesão e o ângulo de atrito interno do solo;

- Apresenta explicitamente a estimativa de carga última à tração de fundações profundas, a partir de uma determinada profundidade crítica;

\subsubsection{Desvantagens}

- Uso duvidoso em estacas e tubulões sem alargamento de base, haja vista ser desenvolvido para placas (ORLANDO, 1985);

- Não faz consideração sobre distintas camadas de solo;

- Não faz referência a sobrecargas na superficie do terreno;

- Resultados teóricos de capacidade de carga contra a segurança, para tubulões de base alargada (DANZIGER, 1983, ORLANDO, 1985).

\subsubsection{O método de Meyerhof}

\subsubsection{Generalidades}

MEYERHOF (1973a) generalizou o método proposto em 1968, estendendo-o para placas de ancoragem e estacas inclinadas submetidas a esforços axiais de carga à tração. Em outro trabalho, estudou o caso de estacas e placas sujeitas a cargas inclinadas de tração (1973b). De uma maneira geral, o caso de estacas ou tubulões sem base alargada é melhor abordado que por MEYERHOF \& ADAMS (1968). 
MEYERHOF (1973a) desenvolvera o método para solo genérico, com coesão e atrito, considerando adesão, ângulo de atrito estaca-solo e um coeficiente adimensional de arrancamento, sem sugerir valores para os dois primeiros parâmetros. MEYERHOF (1973a) limitou a tensão vertical, no caso de estacas, em areia, a uma relação entre o comprimento enterrado e o diâmetro da fundação (L/D), em torno de 15 (VÉSIC, 1967).

Para o caso de uma estaca oblíqua, em relação à vertical, com inclinação menor que $45^{\circ}$, a resistência ao arrancamento não difere muito de uma estaca vertical. Assim, a capacidade de carga à tração pode ser expressa em termos de atrito lateral. Tem-se, então:

$$
P_{u}=\left(c_{a}+\sigma_{v m} K_{u} \operatorname{tg} \delta\right) A_{l}+P_{f}
$$

onde:

$\mathrm{c}_{\mathrm{a}}=$ adesão estaca-solo;

$\sigma_{\mathrm{vm}}^{\prime}=$ tensão vertical efetiva média, devido o peso de solo;

$\mathrm{K}_{\mathrm{u}}=$ coeficiente de arrancamento;

$\mathrm{A}_{\mathrm{l}}=$ área lateral da estaca;

$\delta=$ ângulo de atrito solo-estaca.

Na Figura 2.4, mostram-se os valores do coeficiente $\mathrm{K}_{\mathrm{u}}$, para estacas escavadas. Os valores de $K_{u}$ para estacas cravadas são maiores que para estacas escavadas e podem ser estimados de ensaios in situ de cone.

Para um valor particular do ângulo de atrito do solo, o valor de $\mathrm{K}_{\mathrm{u}}$ mostra-se aumentar com o aumento da profundidade relativa, $\mathrm{L} / \mathrm{D}$, até um valor máximo $\mathrm{e}$ depois, permanece constante. A profundidade onde o valor de $\mathrm{K}_{\mathrm{u}}$ atinge o valor máximo é designado por profundidade crítica. A partir da profundidade crítica, a capacidade ao arrancamento pode ser analisada usando o coeficiente limite de arrancamento, empregando um aumento linear do atrito lateral médio com um ulterior aumento na profundidade de embutimento. Este coeficiente ao arrancamento, contudo, aumenta com o aumento de $\phi$.

RAO \& VENKATESH (1985) relataram que para estacas em areia densa submersa, valores de $\mathrm{K}_{\mathrm{h}}$ estão em razoável aproximação com a teoria de MEYERHOF. Em contrapartida, em areias densas secas, os valores de $\mathrm{K}_{\mathrm{h}}$ obtidos de 
ensaios de laboratório estão próximos aos coeficientes de empuxo passivo de Rankine.

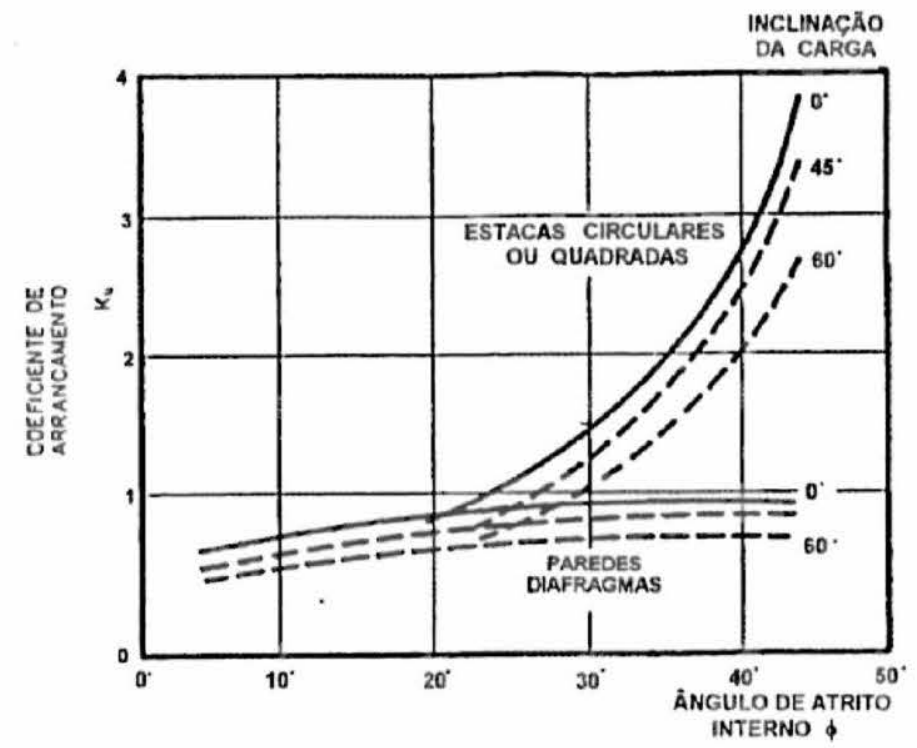

FIGURA 2.4 - Coeficientes Teóricos de Arrancamento $\left(\mathrm{K}_{\mathrm{u}}\right)$ para Estacas Escavadas (MEYERHOF, 1973a, apud CARVALHO, 1991).

\subsubsection{Vantagens}

- Limita o atrito lateral para estacas, a um valor máximo, conforme se observa na prática $(\mathrm{L} / \mathrm{D}=15)$;

- Trata especificamente de fundações rasas e profundas, com e sem base alargada;

- Aplicado conjuntamente com parâmetros sugeridos por DAS et al. (1977), com $\phi$ em função de $\mathrm{D}_{\mathrm{r}}$, pode conduzir a bons resultados, geralmente conservadores, para tubulões sem base alargada (ORLANDO, 1985).

\subsubsection{Desvantagens}

- Na generalização de seu método de 1968, MEYERHOF (1973a,b) continuou não considerando sobrecargas na superficie do terreno e nem camadas distintas de solo; 
- Não havendo sugestão dos valores a adotar para a adesão e o ângulo de atrito estaca-solo, pode haver grande dispersão entre os resultados calculados e os determinados em provas de carga;

- Ao se utilizar parâmetros sugeridos por MEYERHOF (1973a), pode haver tendência a resultados contrários à segurança para tubulões sem base alargada (ORLANDO, 1985) ou para estacas brocas (MATOS, 1989) e escavadas (CARVALHO, 1991).

\subsubsection{O método de Grenoble}

\subsubsection{Generalidades}

Desenvolvido na Universidade de Grenoble, conjuntamente com a estatal francesa de eletricidade (E.D.F.), a partir dos trabalhos de vários pesquisadores, entre os quais pode-se destacar a tese de doutouramento de MARTIN (1966), que de acordo com DANZIGER (1983), engloba toda a metodologia aplicada à previsão de carga última de fundações axialmente tracionadas.

É um método que envolve quase todos os tipos de fundação, estudados em modelos reduzidos de estacas, placas, sapatas e tubulões com e sem base alargada. As considerações teóricas foram aferidas em vários países, através de provas de carga, em escala natural. $\mathrm{O}$ método considera um solo genérico com determinado peso específico, ângulo de atrito e coesão.

Neste método, a ruptura de uma fundação tracionada pode se dar por cisalhamento generalizado, quando a superficie de ruptura é composta de retas inclinadas com a vertical, atingindo a superficie do terreno, ou por cisalhamento localizado, quando a superficie de ruptura localiza-se ao redor da base da fundação. No primeiro caso, comportam-se as estacas cilindricas ou prismáticas.

Para o caso de estacas, MARTIN (1973) observou que existe uma zona do solo junto à mesma que permanece a ela solidária, na ruptura, sendo assimilada, em relação a um plano vertical, a uma reta, inclinada de um certo ângulo $\lambda$ e que atinge a 
superficie do terreno (Figura 2.5). Sem dúvida, a consideração da superficie de ruptura apresentar-se como uma linha reta, é uma simplificação de cálculo.

A carga de ruptura de uma estaca cilíndrica, ou tubulão sem alargamento de base, em solo homogêneo, é a soma da resistência ao cisalhamento mobilizada ao longo da superficie de ruptura, do peso da fundação, do peso do solo solidário à estaca, no processo de ruptura e da sobrecarga, atuante na superficie, quando esta existir.

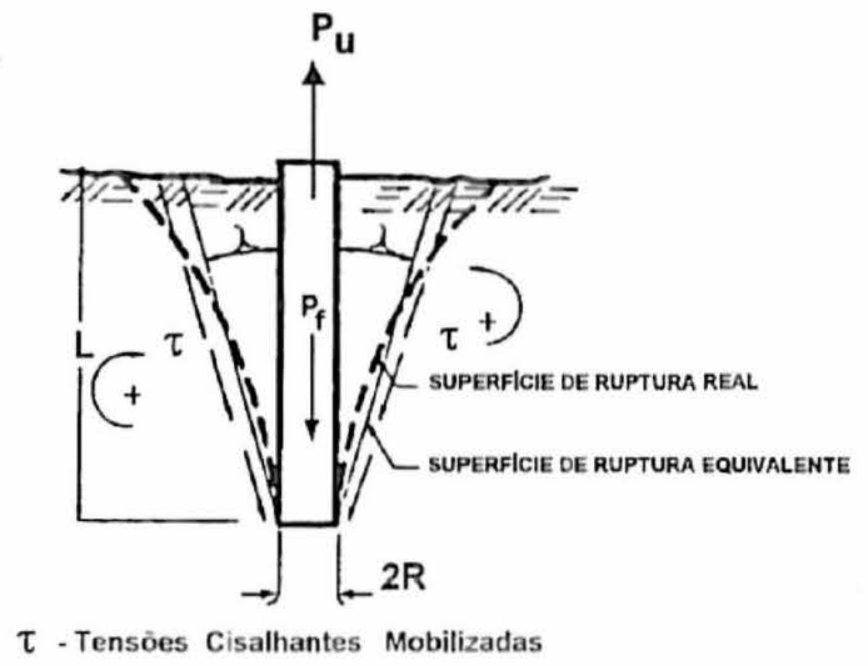

FIGURA 2.5 - Superficie de Ruptura para Estacas em Solos Homogêneos (MARTIN, 1973).

$\mathrm{O}$ ângulo $\lambda$ depende do modo de instalação da estaca, de sua profundidade, da sua geometria da base e da heterogeneidade do solo. BIAREZ \& BARRAUD (1968) sugeriram adotar para estacas $\lambda=-\phi / 8$, entretanto, o melhor meio de avaliá-lo é através de provas de carga. Ressalte-se que o sinal negativo é apenas convenção: indica que a superficie de ruptura abre em direção ao nivel do terreno.

Desta forma, a capacidade de carga à tração é:

$$
P_{u}=P_{f_{\phi}}+P_{f_{c}}+P_{q}+P_{\gamma}+P_{f}
$$

onde:

a) Termo de Atrito:

$$
P_{f_{\phi}}=A_{l} \gamma L M_{\phi}
$$


$\operatorname{com} M_{\phi}=M_{\phi_{o}}[1-(1 / 3) \operatorname{tg} \lambda(L / R)]$

sendo $M_{\phi_{o}}=\operatorname{sen} 2(\phi+\lambda) / 4 \cos ^{2} \lambda$

b) Termo de Coesão:

$$
\begin{gathered}
P_{f_{c}}=A_{l} c M_{c} \\
\operatorname{com} \quad c_{\mathrm{o}}=\left\{-(\operatorname{tg} \lambda / \operatorname{tg} \phi)+(\mathrm{f} / \mathrm{H}) \cos \phi\left[1+\left({ }^{\operatorname{tg} \lambda} / \operatorname{tg} \phi\right)\right]\right\}
\end{gathered}
$$

sendo $(f / H)=\operatorname{tg}\left(\frac{\pi}{4}+\frac{\phi}{2}\right) \frac{\cos n-\operatorname{sen} \phi \cos m}{\cos n+\operatorname{sen} \phi \cos m}$

em que $m=-\pi / 4+\phi / 2+\lambda$

e $\quad n=\operatorname{arcsen}(\operatorname{sen} \phi \cdot \operatorname{senm})$

c) Termo de Sobrecarga:

$$
P_{q}=A q_{o} M_{q}
$$

$\operatorname{com} M_{q}=M_{c}(\operatorname{tg} \phi+\operatorname{tg} \lambda)$

sendo $\mathrm{q}_{\mathrm{o}}=$ sobrecarga uniforme, infinitamente extensa, atuante na superficie do terreno.

d) Termo de Gravidade:

$$
P_{\gamma}=A_{l} \gamma L M_{\gamma}
$$


$\operatorname{com} M_{r}=M_{\gamma_{o}}[1-1 / 3 \operatorname{tg} \lambda(L / R)]$

sendo $M_{\gamma_{o}}=-1 / 2 \operatorname{tg} \lambda$

e) Termo do Peso Próprio

Adiciona-se o peso próprio $\mathrm{P}_{\mathrm{f}}$ da fundação, aos termos anteriores.

A capacidade de carga, fica, finalmente:

$$
P_{u}=A_{t}\left[c M_{c}+\gamma L\left(M_{\phi}+M_{\gamma}\right)+q M_{q}\right]+P_{f}
$$

onde:

$A_{1}=$ Área lateral enterrada da estaca

$$
\left(M_{\phi}+M_{\gamma}\right)=\frac{\operatorname{sen} \phi \cos (\phi+2 \lambda)}{2 \cos ^{2} \lambda}\left[1-1 / 3 \operatorname{tg} \lambda \frac{D}{R}\right]
$$

Os coeficientes adimensionais de capacidade de carga à tração $\mathrm{M}_{\mathrm{C}},\left(\mathrm{M}_{\phi}+\mathrm{M}_{\gamma}\right)$ e $\mathrm{M}_{\mathrm{q}}$ foram apresentados em forma de ábaco, em função de $\phi$ e $\mathrm{L} / \mathrm{R}$, por MARTIN (1973). DANZIGER \& PEREIRA PINTO (1979a) forneceram os valores desses coeficientes, em forma tabular, para $\phi$ até $35^{\circ} \mathrm{e} \mathrm{L} / \mathrm{R}$ até 30 .

No caso de terrenos estratificados, o cálculo de capacidade de carga é feito considerando-se a resistência de cada camada isoladamente, sob o efeito de sobrecarga das camadas sobrejacentes. Para terrenos submersos, utiliza-se o $\gamma_{\text {sub }}$ tanto para o solo quanto para a fundação.

DANZIGER (1983) concluiu que para tubulões com e sem base alargada, a consideração de $\lambda=0$ (superficie de ruptura cilindrica) traz melhores resultados de previsão de capacidade de carga à tração, do que para $\lambda=-\phi / 8$ (superficie de ruptura em forma de tronco de cone), em razão da própria observação da superficie de ruptura nos mesmos, e isto era tanto mais marcante, quanto maior fora a profundidade relativa das fundações. ORLANDO (1985) e CARVALHO (1991) chegaram à mesma conclusão, estudando tubulões sem base alargada e estacas 
escavadas, respectivamente. DANZIGER (1983), ORLANDO (1985) e CARVALHO (1991) concluiram que para $\lambda=-\phi / 8$, os valores teóricos superestimam a resistência à tração, enquanto que para $\lambda=0^{\circ}$, os valores estão ligeiramente a favor da segurança, mas com boa aproximação com aqueles verificados nas provas de carga.

Contudo, MATOS (1989) encontrou para $\lambda=0$ valores contra a segurança, embora o autor esclarecesse que resultados mais realistas foram encontrados quando baseados em parâmetros de resistência efetiva ou residual do solo.

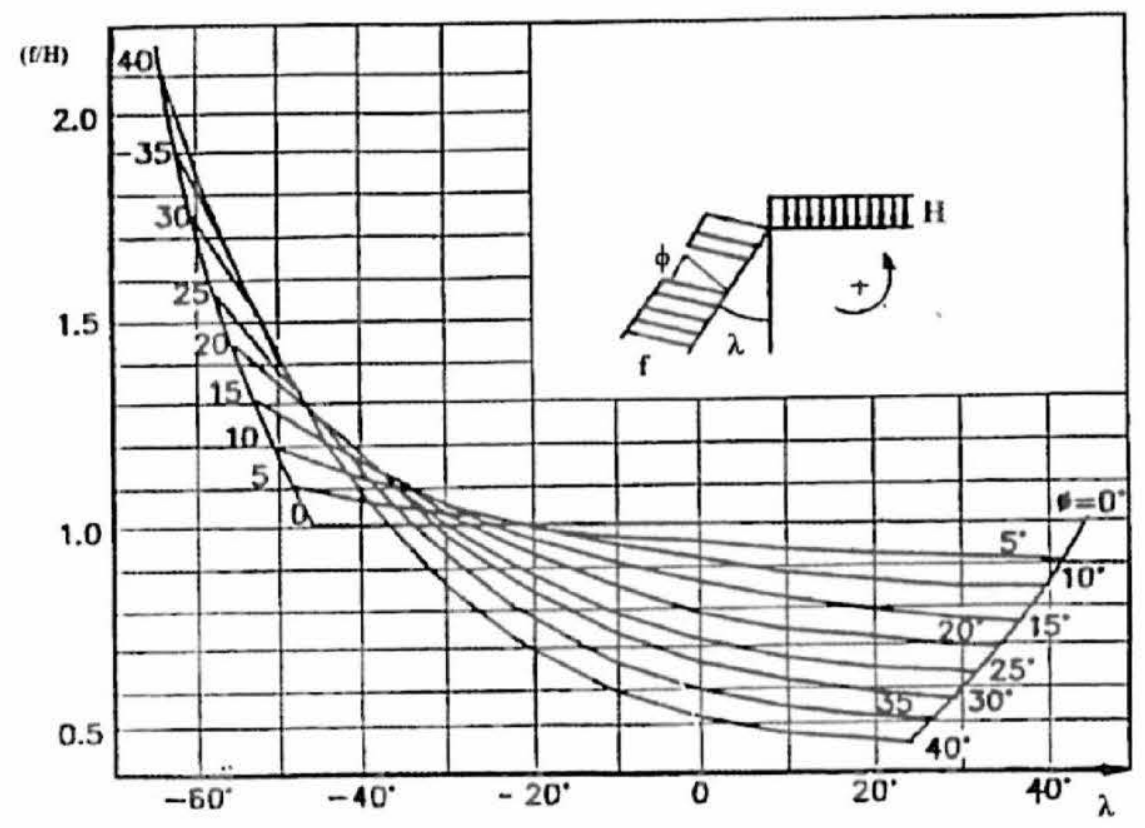

FIGURA 2.6 - Ábaco do Coeficiente de Empuxo (f/H), em função de $\phi$ e $\lambda$, em Meio Coesivo (MARTIN, 1973, apud CARVALHO, 1991).

\subsubsection{Vantagens}

- pode ser considerado o método mais embasado teoricamente e com melhores resultados práticos, no cálculo de capacidade de carga à tração, em função da proposição na formação da superficie de ruptura, distintas conforme o tipo de fundação, profundidade e tipo de solo, além de considerar o efeito de sobrecargas na superficie do terreno;

- DANZIGER (1983) concluiu ser este o método que conduz a melhores resultados, na previsão de carga última à tração, tanto para sapatas, quanto para tubulões com ou sem base alargada, não necessitando de nenhuma adaptação, ou no 
máximo, uma pequena modificação, qual seja, a de fazer $\lambda=0^{\circ}$ na parcela do fuste, admitindo-se, portanto, que a ruptura se dá ao longo da superficie lateral do tubulão;

- O metódo foi comprovado em provas de carga em verdadeira grandeza, em vários paises, o que tornou possível a aferição da metodologia proposta.
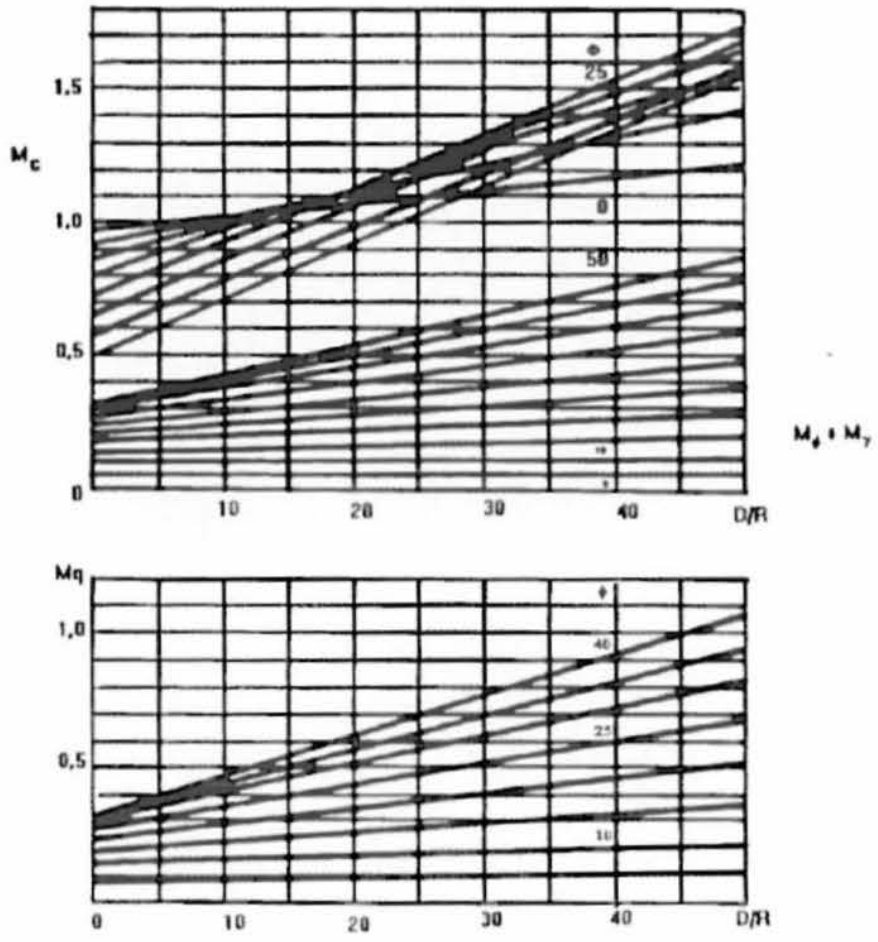

FIGURA 2.7 - Ábaco do Termo de Coesão $\left(\mathrm{M}_{\mathrm{c}}\right)$, Atrito e Gravidade $\left(\mathrm{M}_{\phi}+\mathrm{M}_{\gamma}\right)$, em Função de $\phi$ e $\lambda$ MARTIN (1973).

\subsubsection{Desvantagens}

- Em função do extenso tratamento teórico dispensado ao método, o seu emprego pode tornar-se moroso, devido a quantidade de parâmetros envolvidos, expostos por meio de diversos gráficos, ainda mais se o solo é genérico, ou seja, possui coesão e atrito; uma análise computacional faz-se necessária, para evitar excessiva perda de tempo. 


\subsubsection{O método de Das}

\subsubsection{Generalidades}

DAS et al. (1977) demonstraram que a tensão de resistência lateral crescia linearmente com a relação (L/D), em testes realizados em modelos de estacas verticais de madeira, em areias secas fofa, média e densa. A superficie dessas estacas era rugosa, produzida pela colagem de grão de areia, em torno do fuste das mesmas. Eles sugeriram adotar, para uma estimativa conservadora, ângulo de atrito estaca-solo $(\delta)$ igual a $\mathrm{m} \phi$, onde $\mathrm{m}$ é cerca de 0,4 , para areia muito fofas $\left(\mathrm{D}_{\mathrm{r}} \cong 10 \%\right)$, aumentando com a compacidade relativa até cerca de 1,0 , para areias densas $\left(D_{r} \geq 70 \%\right)$, conforme a Figura 2.8 .

DAS \& ROZENDAL (1983) chamaram a atenção para o fato de que os coeficientes de arrancamento $\mathrm{K}_{\mathrm{u}}$ foram considerados como conhecidos, sendo, então, os parâmetros $\delta / \phi$ deduzidos. Esses autores verificaram que o atrito lateral crescia até certa profundidade critica, a partir da qual permanecia constante. Eles concluiram que

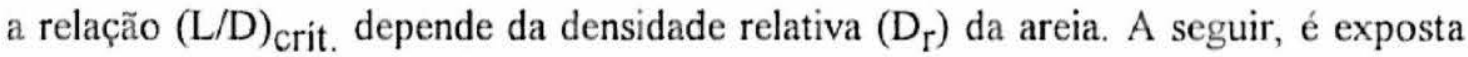
metodologia para o cálculo da capacidade de carga à tração, de estacas escavadas em areia, proposta por DAS (1983):

1) com o diâmetro $D$ e o comprimento enterrado $L$ da estaca, calcula-se a relação (L/D);

2) estima-se a compacidade relativa $\left(D_{r}\right)$ da areia;

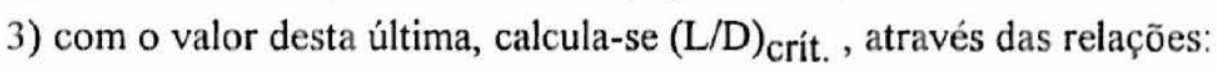

$$
\begin{aligned}
& \text { a) para } \operatorname{Dr} \leq 70 \%: \quad(L / D)_{\text {crit. }}=0,156 D_{r}+3,58 \\
& \text { b) para } \operatorname{Dr}>70 \%:(L / D)_{\text {crit. }}=14,5
\end{aligned}
$$

4.a) se (L/D) obtido em (1) for menor que (L/D) crít, calcula-se a capacidade de carga pela relação:

$$
P_{u}=\pi / 2 D \gamma L^{2} K_{u} \operatorname{tg} \delta+P_{f}
$$

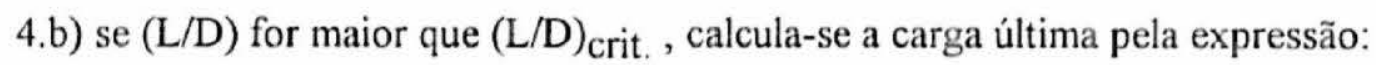




$$
P_{u}=\pi D \gamma L_{\text {crit. }} K_{u} \operatorname{tg} \delta\left(L-L_{\text {crit. }} / 2\right)+P_{f}
$$

onde:

$$
\mathrm{K}_{\mathrm{u}}=\text { coeficiente de arrancamento (Figura 2.4) }
$$

CARVALHO (1991) encontrou boa aproximação entre os resultados de provas de carga e os de previsão por este método adaptado. Como o método fora desenvolvido exclusivamente para areias puras, esse autor fez a inclusão da parcela devida a adesão.

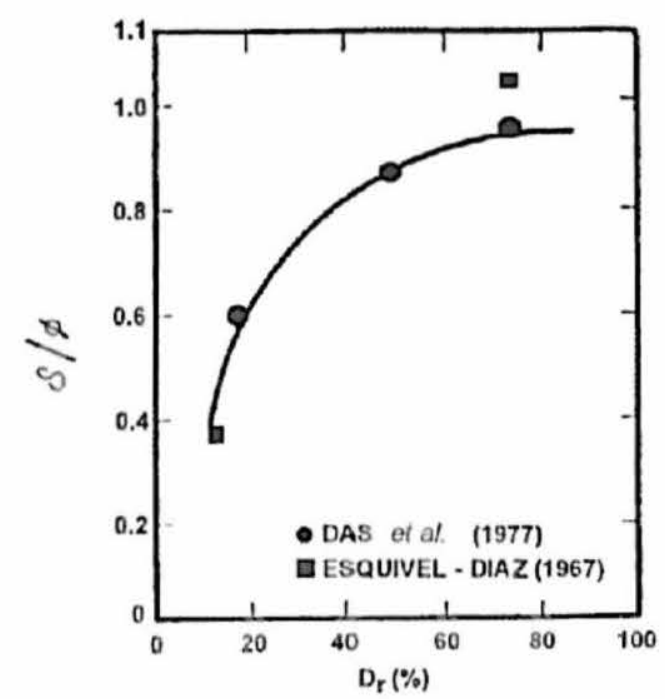

FIGURA 2.8 - Variação de $\delta / \phi$ com $\mathrm{D}_{\mathrm{r}}$ (DAS et al., 1977).

\subsubsection{Vantagens}

- É de aplicação bastante fácil;

- Os parâmetros que fazem parte da metodologia para o cálculo de carga última à tração, estão em gráficos bastantes simples, o que diminui sobremaneira o processo de cálculo.

\subsubsection{Desvantagens}

- O método foi desenvolvido para areias puras, com compacidade entre fofa e densa, não havendo a certeza de extrapolação dos resultados para outros tipos de 
solos, ou diferentes camadas do terreno, como observaram DAS \& ROZENDAL (1983).

- Não considera sobrecargas na superficie do terreno.

\subsubsection{O método da teoria da resistência lateral (ou do atrito lateral)}

\subsubsection{Generalidades}

Esta teoria foi desenvolvida para o cálculo da carga última à compressão de estacas, admitindo-se que a ruptura ocorra no contato solo-estaca. Entretanto, podese utilizá-la no cálculo de capacidade de carga à tração, desde que se faça algumas alterações, como veremos a seguir.

Segundo POULOS \& DAVIS (1980), a tensão de cisalhamento máxima $\left(\tau_{\mathrm{S}}\right)$, unitária, na superficie do fuste de uma estaca vertical é considerada obedecendo à Lei de Coulomb:

$$
\tau_{\mathrm{s}}=\mathrm{c}_{\mathrm{a}}+\sigma_{\mathrm{h}} \operatorname{tg} \delta
$$

onde:

$$
\sigma_{\mathrm{h}}=\text { tensão horizontal (normal ao contato solo-estaca). }
$$

Assim, em termos de tensões efetivas médias, a resistência lateral última $\left(\mathrm{P}_{\text {lu }}\right)$ é a integração da resistência lateral unitária, ao longo de todo o fuste da estaca, conforme abaixo:

$$
\mathrm{l}_{\mathrm{u}}=\int_{0}^{\mathrm{L}} \mathrm{p}\left(\mathrm{c}_{\mathrm{a}}+\sigma_{\mathrm{vm}}^{\prime} \mathrm{K}_{\mathrm{h}} \operatorname{tg} \delta\right) \mathrm{dz}
$$

onde:

$\mathrm{p}=$ perimetro da estaca.

Desse modo, a carga última à tração é:

$$
\mathrm{P}_{\mathrm{u}}=\mathrm{P}_{\mathrm{l}_{\mathrm{u}}}+\mathrm{P}_{\mathrm{f}}=\int_{0}^{\mathrm{L}} \mathrm{p}\left(\mathrm{c}_{\mathrm{a}}+\sigma_{\mathrm{vm}}^{\prime} \mathrm{K}_{\mathrm{h}} \operatorname{tg} \delta\right) \mathrm{dz}+\mathrm{P}_{\mathrm{f}}
$$


KULHAWY (1985) afirmou que fundações retas tracionadas apresentam ruptura principalmente ao longo da interface solo-estaca, conduzindo a uma superficie cilindrica de cisalhamento. De acordo com esses autores, quando inicia-se o carregamento à tração naquelas fundações, forma-se uma zona de cisalhamento Riedel no solo, ao longo de planos nas quais as condições de ruptura de MohrCoulomb são satisfeitas. Contudo, grandes deslocamentos ao longo dessa zona não são ainda permitidas; então, o solo é forçado a desenvolver deslocamentos cisalhantes, com o posterior avanço do movimento ascendente da fundação, o que resulta finalmente em um deslocamento cisalhante continuo. Este cisalhamento contínuo ocorre muito próximo à interface solo-estaca e efetivamente define uma superficie de ruptura cilindrica.

Confirmando esse fato, ORLANDO (1985) e CARVALHO (1991) conseguiram boa aproximação do uso deste método, com relação a resultados de provas de carga, em escala natural. Segundo DANZIGER (1983) e MATOS \& MILITITSKY (1990) o modelo de ruptura mais compativel com a realidade é o que considera o desenvolvimento de uma superficie de ruptura cilindrica, daí a conveniência deste método.

\subsubsection{Vantagens}

- Para fundações profundas retas (estacas e tubulões sem base alargada), a ruptura pelo contato solo-estaca parece ser a mais realista;

- É de uso fácil e rápido.

\subsubsection{Desvantagens}

- Por possuir parâmetros em sua formulação, que podem variar em largo espectro, pode conduzir a resultados diversos;

- Não há, até o presente, um pleno conhecimento da relação a adotar-se, entre os atritos laterais à tração e à compressão, o que pode causar resultados inesperados. 


\subsection{Avaliação dos Parâmetros Geotécnicos ḍ̣ Solo eldo Conjunto Estaca-Solo.}

\subsubsection{Generalidades}

Ao se apresentar os métodos de previsão de carga última à tração para estacas, depara-se com vários parâmetros geotécnicos do solo e do conjunto estacasolo, tais como o peso específico, a coesão, o ângulo de atrito interno do solo, o coeficiente de empuxo do solo, o ângulo de atrito estaca-solo, a adesão estaca-solo e a tensão vertical efetiva, devida ao peso próprio do solo.

$\mathrm{O}$ peso específico, o ângulo de atrito interno interno do solo e a coesão podem ser determinados a partir de ensaios de laboratório. A tensão vertical efetiva, em areias, cresce até uma certa profundidade, após a qual permanece constante, como será adiante detalhado. Quanto aos demais parâmetros, parece ser o coeficiente de empuxo lateral o de mais dificil determinação.

Neste ítem, comentam-se as sugestões de vários autores, no sentido de melhor avaliar-se os parâmetros geotécnicos do solo e do conjunto estaca-solo, utilizados na previsão de cargas últimas das fundações tracionadas. Ressalta-se que uma boa seleção desses parâmetros conduz a melhores estimativas dos diversos métodos, aproximando-as dos resultados verificados em ensaios em escala natural.

\subsubsection{Tensão Vertical Efetiva Média}

A tensão vertical efetiva é tomada, geralmente, como sendo igual ao peso do solo, multiplicado por uma determinada $\operatorname{cota}\left(\sigma_{\mathrm{V}}^{\prime}=\gamma . \mathrm{z}\right)$.

Entretanto, segundo POULOS \& DAVIS (1980), pesquisas realizadas por KÉRISEL (1961) e VÉSIC (1961), em areias, revelaram que as resistências unitárias de fuste e de ponta de uma estaca não crescem, necessariamente, com a profundidade, mas alcançam valores quase que constantes, após uma determinada profundidade. Estas caracteristicas foram confirmadas em pesquisas subseqüentes (e.g., BCP Comm., 1971; HANNA \& TAN, 1973). Este fenômeno foi atribuido, por VÉSIC (1967), ao arqueamento da areia, em planos verticais, concomitantemente com o recalque da estaca, semelhante àquele observado por TERZAGHI (1943), com 
relação a túneis. Há, contudo, outras hipóteșes, como o arqueamento em planos horizontais.

MEYERHOF (1976) supôs que o arqueamento seja proveniente ainda do esmagamento dos grãos e compressibilidade do solo. BEREZANTZEV et al. (1961) sugeriram considerar uma redução da tensão vertical, através de um coeficiente $\alpha_{\mathrm{T}}$, dado em função de L/D e $\phi$, de acordo com a Tabela 2.2, tal que:

$$
\alpha_{\mathrm{T}}=\frac{\sigma_{\mathrm{vr}}^{\prime}}{\sigma_{\mathrm{vm}}^{\prime}}
$$

onde $\sigma_{\mathrm{Vr}}^{\prime}$ é a tensão média resultante.

TABELA 2.2 - Valores de $\alpha_{\mathrm{T}}$, em Função de L/D e $\phi$ (BEREZANTZEV et al., 1961)

\begin{tabular}{|c|c|c|c|c|c|}
\hline L/D & \multicolumn{5}{|c|}{$\phi^{\circ}$} \\
\hline & 26 & 30 & 34 & 37 & 40 \\
\hline 5 & 0,75 & 0,77 & 0,81 & 0,83 & 0,85 \\
\hline 10 & 0,62 & 0,67 & 0,73 & 0,76 & 0,79 \\
\hline 15 & 0,55 & 0,61 & 0,68 & 0,73 & 0,77 \\
\hline 20 & 0,49 & 0,57 & 0,65 & 0,71 & 0,75 \\
\hline 25 & 0,44 & 0,53 & 0,63 & 0,70 & 0,74 \\
\hline
\end{tabular}

VÉSIC (1970) concluiu que o aumento do atrito lateral da estaca cresce até uma profundidade critica $\left(\mathrm{L}_{\text {crit. }}\right)$ que varia de aproximadamente 10 diâmetros, para areias muito fofas, até cerca de 20 diâmetros, para areias muito compactas. Entretanto, pode-se adotar um valor médio de 15 diâmetros, para qualquer compacidade média da areia.

POULOS \& DAVIS (1980) sugeriram adotar um diagrama simplificado, da tensão vertical ao longo do fuste da estaca, em areias, conforme a Figura 2.9.

LEHANE et al. (1993) ensaiaram duas estacas de aço, com ponta em forma e cone, ambas possuindo $0,102 \mathrm{~m}$ de diâmetro e $6 \mathrm{~m}$ de comprimento, embutidas em areia de duna, na costa francesa. As estacas foram macaqueadas rapidamente. Nesses 


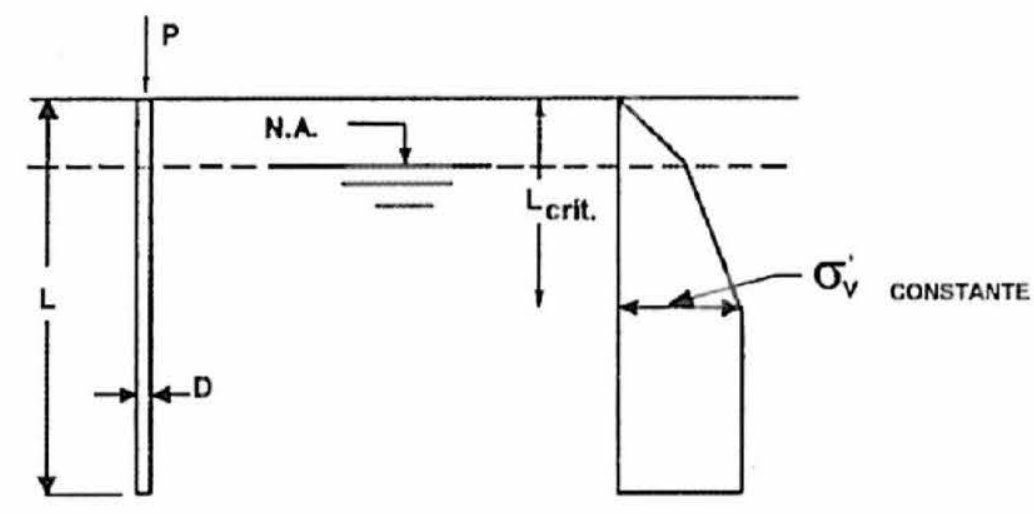

FIGURA 2.9 - Distribuição Simplificada da Tensão Vertical Adjacente à Estaca, em Areia (POULOS \& DAVIS, 1980).

ensaios, mediram as tensões efetivas desenvolvidas durante a instalação e durante as provas de carga nas duas estacas, embutidas na areia quartzosa medianamente densa.

Os resultados mostraram novos rumos no mecanismo que controla o atrito lateral em areia. Primeiro, ficou demonstrado que as tensões desenvolvidas em qualquer horizonte do solo depende grandemente da distância deste horizonte à ponta da estaca (h) e do estado de tensões inicial do solo. Segundo, o carregamento da estaca induz a mudanças nas tensões efetivas radiais, associadas com a estrutura do solo, estabelecidas pela instalação e fenômeno de dilatação na interface estaca-solo.

Concluiram que a resistência lateral local é controlada por $\tau_{\mathrm{f}}=\sigma_{\mathrm{rf}}^{\prime} \tan \delta_{\mathrm{f}}$, em que $\sigma_{\mathrm{rf}}^{\prime}$ é a tensão efetiva radial local na ruptura e $\delta_{\mathrm{f}}$ é o ângulo de atrito estaca-solo medido em ensaios de carregamento em estacas. A tensão efetiva radial local na ruptura tem duas componentes principais: a tensão efetiva radial local, após a instalação da estaca, e o acréscimo da tensão efetiva radial local, devido o carregamento da estaca. Os valores locais das tensões radiais efetivas, após a instalação da estaca, dependem da densidade relativa, da profundidade da camada de solo particular e da posição relativa da ponta , ou seja, da distância da ponta da estaca até o horizonte do solo.

As reduções observadas das tensões efetivas locais radiais com $\mathrm{h} / \mathrm{R}$ (onde $\mathrm{R}$ é o raio da estaca) dá uma explicação racional para a tendência das tensões cisalhantes médias, ao longo do fuste estabilizarem-se com a profundidade. Mudanças nas 
tensões radiais efetivas são causadas pelo carregamento da estaca que podem ser relacionadas à dilatação da interface e os efeitos da rotação das tensões principais na massa de areia.

\subsubsection{Adesão Estaca-Solo}

POULOS \& DAVIS (1980) relataram que a adesão estaca-solo varia consideravelmente com muitos fatores, incluindo o tipo de solo, o tipo de estaca e o modo de sua instalação. Muita atenção tem-se dado à relações entre a adesão estacasolo e à coesão não drenada do solo $\left(c_{u}\right)$, através de um coeficiente de adesão $(\alpha=$ $\left.\mathrm{c}_{\mathrm{a}} / \mathrm{c}_{\mathrm{u}}\right)$.

TOMLINSON (1957) apresentou um ábaco que relaciona $\alpha \operatorname{com} \mathrm{c}_{\mathrm{u}}$, para estacas cravadas em argila. Esse autor concluiu que há um decréscimo na coesão não drenada da argila, durante a cravação de estacas, devido a formação de fissuras na interface estaca-solo, aumentando com o pré-adensamento da argila. Nessas fissuras pode haver fluxo d'água, causando o amolecimento da argila, junto à estaca, com a conseqüente diminuição da coesão da mesma. SOWA (1970) encontrou valores de $\alpha$ igual a 0,31 , para estacas escavadas em argila, de $12 \mathrm{~m}$ de comprimento e $0,53 \mathrm{~m}$ de diâmetro.

POULOS \& DAVIS (1980) afirmaram que para estacas escavadas, não há muitos dados na literatura, limitando-se apenas a estudos na argila de Londres. Esses valores encontram-se na Tabela 2.3 .

TABELA 2.3 - Coeficientes de Adesão $(\alpha)$ para Estacas Escavadas em Argila.

\begin{tabular}{|c|c|c|}
\hline Tipo de Solo & $\alpha$ & valor \\
\hline Argila de Londres & $\mathrm{c}_{\mathrm{a}} / \mathrm{c}_{\mathrm{u}}$ & $\begin{array}{c}0,25-0,70 \\
\text { (média } 0,45)\end{array}$ \\
\hline Argila Sensitiva & $\mathrm{c}_{\mathrm{a}} / \mathrm{c}_{\mathrm{r}}$ & 1 \\
\hline $\begin{array}{c}\text { Argila Altamente } \\
\text { Expansiva }\end{array}$ & $\mathrm{c}_{\mathrm{a}} / \mathrm{c}_{\mathrm{u}}$ & 0,5 \\
\hline Nota: $\mathrm{c}_{\mathrm{r}}$ : resistência amolgada \\
\hline
\end{tabular}


BOWLES (1988) apresentou valores de $\alpha$, em função de $c_{\mathrm{u}}$, encontrados por TOMLINSON (1971), juntamente com aqueles fornecidos pelo Instituto Americano do Petróleo (API, 1984).

POTYONDY (1961) realizou vários experimentos, visando a determinação do coeficiente de adesão e do coeficiente de atrito, em ensaios de cisalhamento direto, envolvendo interfaces de solo com diversos materiais, tais como concreto, aço e madeira. Basicamente, as superficies produzidas eram lisas e rugosas. Na interface de concreto, a superficie lisa foi conseguida com moldagem do concreto em uma fôrma compensada, plana, e a superficie rugosa, obtida através da moldagem em uma fôrma irregular. A primeira amostra representa a superficie de um concreto liso, feito em uma forma de madeira plana, e a segunda representa a superficie de um concreto áspero, moldado contra a parede de uma escavação no terreno. O solo estudado consistiu em areia (seca e saturada), argila, solo coesivo granular (50\% areia e $50 \%$ argila) e silte. São apresentados na Tabela 2.4 os valores dos coeficientes de adesão encontrados por POTYONDY (1961) para argila e solo coesivo granular, em contato com concreto liso e rugoso.

TABELA 2.4- Valores de Coeficiente de Adesão da Interface Estaca-Solo, para Superficies de Concreto Lisa e Rugosa (POTYONDY, 1961).

\begin{tabular}{|l|c|l|c|}
\hline \multicolumn{2}{|c|}{ Solo Granular Coesivo $(\mathrm{w}=17 \%)$} & \multicolumn{2}{c|}{ Solo Granular Coesivo $(\mathrm{w}=15 \%)$} \\
\hline Concreto & $\mathrm{c}_{\mathrm{a}} / \mathrm{c}$ & \multicolumn{1}{c|}{ Concreto } & $\mathrm{c}_{\mathrm{a}} / \mathrm{c}$ \\
\hline liso & 0,48 & liso & 0,69 \\
\hline rugoso & 0,78 & rugoso & 0,81 \\
\hline \multicolumn{2}{|c|}{ Argila (IC $=0,94 ; \mathrm{w}=22,8 \%)$} & \multicolumn{2}{c|}{ Argila $(\mathrm{IC}=0,73 ; \mathrm{w}=26,1 \%)$} \\
\hline \multicolumn{2}{|c|}{ Concreto } & $\mathrm{c}_{\mathrm{a}} / \mathrm{c}$ & \multicolumn{2}{c|}{ Concreto } & $\mathrm{c}_{\mathrm{a}} / \mathrm{c}$ \\
\hline liso & 0,57 & liso & 0,52 \\
\hline rugoso & -- & rugoso & -- \\
\hline
\end{tabular}

\subsection{4. Ângulo de atrito da interface solo-estaca}

Na Tabela 2.5 são apresentados os valores do coeficiente de atrito $\left(f_{\phi}=\delta / \phi\right)$ encontrados por POTYONDY (1961) para areia seca e saturada, argila , solo coesivo 
granular e silte, em contato com concreto liso e rugoso. ORLANDO (1985), MATOS (1989) e CARVALHO (1991) utilizaram a recomendação de POTYONDY (1961) em seus trabalhos.

DAS (1977) sugeriu valores de $\delta / \phi$ em função de $D_{r}$, para areia, conforme já citado no ítem 2.2.7.0. LEHANE et al. (1993) concluiram que o ângulo de atrito estaca-solo é melhor estimado em ensaios de cisalhamento de interface, a volume constante.

KULHAWY \& PETERSON (1979) estudaram o comportamento tensãodeformação de interfaces areia-concreto, em ensaios de cisalhamento direto, em laboratório. Segundo esses autores, a definição de superficies lisas e rugosas varia entre diversos pesquisadores. Tipicamente, superficies lisas são preparadas vertendo concreto contra uma placa de aço ou de vidro, enquanto superficies rugosas são criadas vertendo concreto diretamente contra o solo a ser ensaiado, ou em uma superficie rugosa pulverizada.

TABELA 2.5 - Valores de ângulo de Atrito Interno do Solo e de Interface EstacaSolo, para Superficies de Concreto Lisa e Rugosa (POTYONDY, 1961).

\begin{tabular}{|c|c|c|c|}
\hline \multicolumn{2}{|c|}{ Areia Densa Seca } & \multicolumn{2}{|c|}{ Areia Densa Saturada } \\
\hline Concreto & $\delta / \phi$ & Concreto & $\delta / \phi$ \\
\hline liso & 0,89 & liso & 0,90 \\
\hline rugoso & 0,98 & rugoso & - \\
\hline \multicolumn{2}{|c|}{ Argila $(\mathrm{IC}=0,94 ; \mathrm{w}=22,8 \%)$} & \multicolumn{2}{|c|}{ Argila $(\mathrm{IC}=0,73 ; \mathrm{w}=26,1 \%)$} \\
\hline Concreto & $\delta / \phi$ & Concreto & $\delta / \phi$ \\
\hline liso & 0,97 & liso & 0,82 \\
\hline rugoso & $\ldots$ & rugoso & -- \\
\hline \multicolumn{2}{|c|}{ Solo Granular Coesivo $(\mathrm{w}=17 \%)$} & \multicolumn{2}{|c|}{ Solo Granular Coesivo $(\mathrm{w}=15 \%)$} \\
\hline Concreto & $\delta / \phi$ & Concreto & $\delta / \phi$ \\
\hline liso & 1,00 & liso & 0,87 \\
\hline rugoso & 1,04 & rugoso & 0,94 \\
\hline \multicolumn{2}{|c|}{ Silte Denso Seco } & \multicolumn{2}{|c|}{ Silte Denso Saturado } \\
\hline Concreto & $\delta / \phi$ & Concreto & $\delta / \phi$ \\
\hline liso & 1,00 & liso & 0,96 \\
\hline rugoso & 1,00 & rugoso & - \\
\hline
\end{tabular}


Entretanto, é fato unânime entre todos os autores que $\delta$ depende do tamanho do grão, angulosidade e distribuição dos tamanhos dos grãos no solo, do teor de umidade do solo, do tipo de material de interface e da textura e das tensões normais da interface.

KULHAWY \& PATERSON (1979) relataram que quatro interfaces de rugosidade foram obtidas, três delas com blocos de concreto pré-fabricados, com superficie lisa, intermediária e rugosa. A quarta interface foi com concreto, moldado na caixa de cisalhamento e deixado curar normalmente.

Os autores concluíram que o comportamento resultante de uma interface depende primariamente da graduação do solo e da face do concreto. Foi encontrado que a rugosidade do solo ou da face do concreto $\left(R_{M}\right)$ pode ser descrita como:

$$
M=\frac{D_{60} D_{10}}{D_{50}}
$$

em que $R_{M}=$ rugosidade do material e $D_{60}, D_{50}$ e $D_{10}$, são, respectivamente, os diâmetros das partículas com 60,50 e 10\% dos grãos menores do solo ou dos agregados finos do concreto. A rugosidade de uma interface pode, então, ser quantificada, pela rugosidade relativa da interface $\left(\mathrm{R}_{\mathrm{R}}\right)$, que pode ser definida como:

$$
R=\frac{R_{C}}{R_{S}}
$$

em que $\mathrm{R}_{\mathrm{C}}$ é a rugosidade da superficie do concreto e $\mathrm{R}_{\mathrm{S}}$ é a rugosidade do solo.

Todos os ensaios apresentaram decréscimo de resistência, ultrapassada a resistência de pico, idêntico ao ocorrido para argilas (estado pós-pico). As amostras foram então descarregadas a zero e, então, recarregadas de volta à posição original da amostra, no ensaio (estado recarregado).

A Tabela 2.6 mostra os valores de rugosidade obtidos nos ensaios e a Figura 2.10 apresenta a relação entre $R_{R} \operatorname{com} \delta / \phi$. 
TABELA 2.6 - Valores de Rugosidade, em Função da Granulometria da Areia (KULHAWY \& PETERSON, 1979).

\begin{tabular}{|c|c|c|c|c|}
\hline Solo & $\begin{array}{c}\mathrm{R}_{\mathrm{S}} \\
(\mathrm{mm})\end{array}$ & $\begin{array}{c}\text { Superficie do } \\
\text { Concreto }\end{array}$ & $\begin{array}{c}\mathrm{R}_{\mathrm{C}} \\
(\mathrm{mm})\end{array}$ & $\mathrm{R}_{\mathrm{R}}$ \\
\hline \multirow{3}{*}{ Areia } & 0,183 & Lisa & 0 & 0 \\
\cline { 2 - 5 } & 0,183 & Intermediária & 0,644 & 3,52 \\
\cline { 2 - 5 } & 0,183 & Rugosa & 1,330 & 7,27 \\
\cline { 2 - 5 } & 0,183 & & 0,260 & 1,42 \\
\hline \multirow{4}{*}{ Aniforme } & 0,275 & Lisa & 0 & 0 \\
\cline { 2 - 5 } & 0,275 & Intermediária & 0,644 & 2,34 \\
\cline { 2 - 5 } Graduada & 0,275 & Rugosa & 1,330 & 4,83 \\
\cline { 2 - 5 } & 0,275 & & 0,644 & 2,34 \\
\hline
\end{tabular}

Concluiu-se também que para superficies rugosas $\left(R_{R}>1\right)$, o ângulo $\delta$ é igual ou maior que $\phi$. Isto implica que a interface é mais resistente que o solo, levando a crer que a ruptura dar-se-á no solo, fora da interface. Por outro lado, para superficies lisas, $\left(R_{R}<1\right)$, é bem provável que a ruptura ocorrerá na interface. O concreto moldado diretamente contra o solo desenvolve uma superficie rugosa, enquanto o concreto moldado em uma fồrma com o solo posto contra ele, após sua cura, conduz a uma superficie lisa.

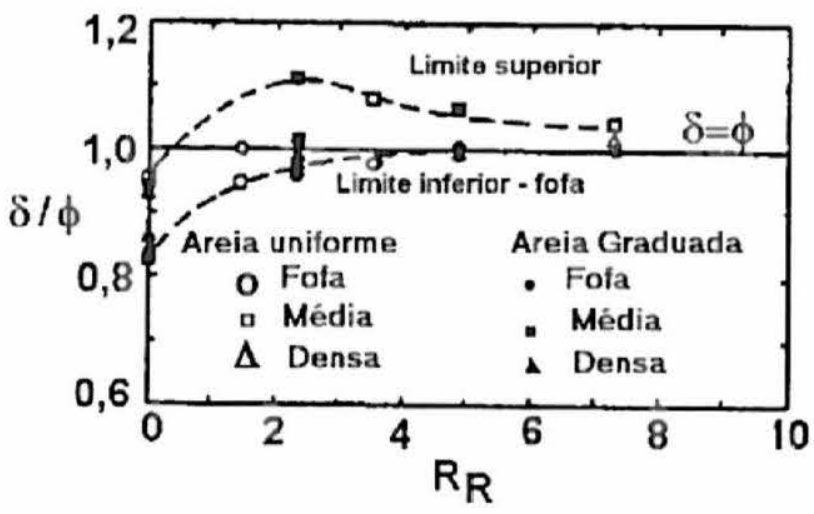

FIGURA 2.10 - Relação entre $\mathrm{R}_{\mathrm{R}}$ e $\delta / \phi$ 


\subsubsection{Coeficiente de Empuxo Horizontal}

RAO \& VENKATESH (1985) afirmaram que o coeficiente de empuxo horizontal depende do ângulo de atrito interno e da densidade do solo, do método de instalação, do coeficiente de embutimento (L/D) e da rugosidade da estaca, sendo, talvez, o parâmetro de determinação mais dificil.

SOWA (1970) concluiu que o empuxo de terra e o atrito lateral podem ser aumentados, em estacas moldadas in loco, em solos arenosos, colocando o concreto no furo tão rapidamente quanto possível e vibrando-o perfeitamente. De fato, devido à pressão radial, considerada hidrostática, exercida pelo concreto junto à parede do solo escavado, há um incremento do coeficiente de empuxo $\mathrm{e}$, portanto, do atrito lateral. Salientou que a resistência ao arrancamento de estacas em solos arenosos é muito mais dependente do empuxo horizontal sobre as estacas e que este pode variar em uma grande faixa de valores. Alegou também que os valores de $\mathrm{K}_{\mathrm{h}}$ são muito sensitivos a pequenas variações nos valores de coesão.

POULOS \& DAVIS (1980) apresentaram em gráfico o valor de $\mathrm{K}_{\mathbf{h}} \cdot \operatorname{tg} \delta$, em função do ângulo de atrito do solo, para estacas escavadas e cravadas, baseados em VÉSIC (1967) e MEYERHOF (1976).

BOWLES (1988) recomendou usar o mesmo $\mathrm{K}_{\mathrm{h}}$ para estacas pré-moldadas cravadas à tração e à compressão, ou então, uma ligeira redução neste parâmetro, para levar em conta a reorientação das partículas durante cravação das estacas e as tensões residuais. Um valor de $\mathrm{K}_{\mathrm{h}}$ maior do que $\mathrm{K}_{\mathrm{O}}$ deve ser apropriado em areia, uma vez que há algum deslocamento de massa de solo. O API (1984) sugeriu usar $\mathrm{K}_{\mathrm{h}}$ $=0,8$ para estacas tracionadas e comprimidas, em areia, para estacas de baixo volume de solo deslocado e $\mathrm{K}_{\mathrm{h}}=1,0$, para estacas de deslocamento.

Para estacas escavadas curtas, em areia, BOWLES (1988) sugeriu os seguintes valores:

\begin{tabular}{|c|c|}
\hline $\mathrm{K}_{\mathrm{h}}$ & $\mathrm{D}(\mathrm{cm})$ \\
\hline $\mathrm{K}_{\mathrm{a}}$ & $\leq 30$ \\
\hline $1 / 2\left(\mathrm{~K}_{\mathrm{a}}+\mathrm{K}_{\Omega}\right)$ & $30 \leq \mathrm{D} \leq 60$ \\
\hline $1 / 3\left(\mathrm{~K}_{\mathrm{a}}+\mathrm{K}_{\mathrm{O}}+\mathrm{K}_{\mathrm{p}}\right)$ & $>60$ \\
\hline
\end{tabular}


em que $\mathrm{K}_{\mathrm{a}}, \mathrm{K}_{\mathrm{p}}$ e $\mathrm{K}_{\mathrm{O}}$, são, respectivamente, os coeficientes de empuxo ativo, passivo e em repouso. A razão desses valores é que para estacas com menores diâmetros de fuste, o arqueamento do concreto úmido não desenvolve muita pressão lateral contra a superficie do solo, ao passo que em maiores diâmetros de fuste (maior que $60 \mathrm{~cm}$ ), maiores pressões na interface solo-estaca são mobilizadas.

Muitos autores utilizaram o coeficiente de empuxo em repouso, na estimativa da carga última de estacas comprimidas e tracionadas. JÁKY (1948) conduziu um estudo teórico sobre $\mathrm{K}_{\mathrm{O}}$ e introduziu a seguinte expressão teórica para calcular o valor de $\mathrm{K}_{\mathrm{O}}$ para solos normalmente consolidados:

$$
\mathbf{K}_{\mathbf{0}}=1-\operatorname{sen} \phi
$$

AL-HUSSAN \& TOWSEND (1975) mostraram que $\mathrm{K}_{\mathrm{O}}$ é dependente da história de tensões da areia, ou seja, da razão de pré-adensamento (OCR). Eles mostraram que $\mathrm{K}_{\mathrm{O}}$ aumenta com o aumento de OCR e com o aumento do esforço de compactação das camadas de areia. Eles concluiram que, para areias normalmente consolidadas (NC), a fórmula de JÁKY (1948) dá uma boa base para o cálculo do valor de $\mathrm{K}_{\mathrm{O}}$.

SAGLAMER (1975) apud HANNA \& GHALY (1992) encontrou que a história de tensões da areia representada pelo OCR é o fator que mais influencia o valor de $\mathrm{K}_{\mathrm{O}}$. Ele propôs a seguinte equação para o cálculo de $\mathrm{K}_{\mathrm{O}}$ para areias $\mathrm{NC}$ :

$$
\mathbf{K}_{\mathbf{0}(\mathbf{N C})}=0,97[1-0,97(\operatorname{sen} \phi)]
$$

MEYERHOF (1976) propôs uma fórmula semi-empirica para estimativa de $\mathrm{K}_{\mathrm{O}}$ para solos sobreadensados $(\mathrm{OC})$. Esta fórmula é:

$$
\mathbf{K}_{0_{(N C)}}=(1-\operatorname{sen} \phi) \sqrt{\mathbf{O C R}}
$$

HANNA \& CARR (1971) mostraram que, variando OCR, a forma do gráfico da carga de arrancamento de fundações versus deslocamento muda e a carga de pico aumenta com o aumento de OCR. 
IRELAND (1957) e BROMS (1963) mostraram que os valores de coeficientes de empuxo $K_{h}$, em ensaios à tração, em estacas cravadas em areia, podem ser iguais ou maiores que $K_{p}$. Contudo, valores de $K_{h}$ são tomados menores que $K_{p}$ em previsão de $\mathrm{c}_{\mathrm{u}}$.

RAO \& VENKATESH (1985) concluiram que $\mathrm{K}_{\mathrm{h}}$ decresce com $\mathrm{L} / \mathrm{D}$, em ensaios de tração, mas aumenta levemente com a rugosidade. Além do mais, valores de $\mathrm{K}_{\mathrm{h}}$ para areia pedregulhosa são maiores que para areia média, exceto para alguns casos isolados, que podem ser devidos à variações na carga lateral real. Deve-se computar uma redução na densidade da areia, devida a submersão, de cerca de $40 \%$. Mas para areias densas, a redução real no atrito lateral é maior que $40 \%$, o que indica que os valores de $\mathrm{K}_{\mathrm{h}}$ são também afetados, e tornam-se menores, naquela condição. Em areias fofas, a redução real é da mesma ordem que aquelas que podem ser consideradas pelo peso unitário submerso e $\phi$ reduzido. Isto implica que o valor de $\mathrm{K}_{\mathrm{h}}$, em areias fofas, permanecem inalterados pela submersão. Em areias densas, $\mathrm{K}_{\mathrm{h}}$ torna-se menor sob submersão, enquanto que, em areias fofas, permanece inalterado.

TOGROL (1973) realizou provas de carga em duas estacas cravadas de tubos de aço, de diâmetro externo de $0,528 \mathrm{~m}$ e de comprimentos de 28 e $30 \mathrm{~m}$, encontrando valores de $\mathrm{K}_{\mathrm{h}}$ iguais 0,73 e 0,68 , respectivamente. Essas estacas estavam embutidas numa camada de silte arenoso.

HANNA \& GHALY (1992) alegaram que em muitas circunstâncias, a história de tensões da areia, representada pelo índice de pré-adensamento (OCR), não é levada em conta para o cálculo da resistência ao arrancamento. Isto resulta em uma considerável discrepância entre a resistência ao arrancamento de fundações instaladas em tipos similares de areia, com diferentes índices de OCR. Acreditam que esta discrepância desapareceria se o efeito do grau de OCR fosse incorporado nos cálculos de resistência ao arrancamento.

\subsection{Relação entre os Atritos Laterais em Estacas Tracionadas e Comprimidas}

Há muita discussão entre os autores acerca do atrito lateral em estacas comprimidas e tracionadas, desde longa data. 
STERN (1908) encontrou atrito à compressão menor que à tração. BOONSTRA (1936) concluiu haver igualdade entre os atritos, tanto à compressão, quanto à tração. LOOS (1937) observou que o atrito lateral em estacas comprimidas era 4 a 7 vezes maior que o encontrado em estacas tracionadas (apud COSTA, 1956).

TERZAGHI (1973) citou que em argilas, o atrito lateral é o mesmo, à tração $\mathrm{e}$ à compressão, em estacas de deslocamento, o mesmo não se verificando em areias, onde o atrito à compressão é maior que à tração, pelo fato de haver uma maior pressão da areia contra a superfície lateral da estaca, quando esta é cravada; ao contrário, no arrancamento, a pressão diminui, e, conseqüentemente, o atrito lateral também diminui.

KÉZDI (1975) é de opinião semelhante. Segundo esse pesquisador, antes da instalação da estaca, o estado de tensões que prevalece no terreno é o de repouso. Se a instalação de uma estaca é acompanhada por um deslocamento do solo vizinho, as tensões normais agindo no fuste da estaca aumentam e forças de atrito lateral surgem ao longo dele. A distribuição de tensões é diferente para estacas cravadas, vibradas, prensadas, etc. Se um furo é aberto para moldagem de estaca in loco, o movimento do solo é direcionado para ele; portanto, as tensões horizontais decrescem.

De acordo com ZEEVAERT (1983), quando a estaca é comprimida, as tensões cisalhantes transmitidas ao solo pela estaca devem aumentar as tensões verticais $\left(\sigma_{\mathrm{V}}^{\prime}\right)$ do solo junto à estaca, aumentando assim a tensão normal efetiva horizontal que o solo exerce sobre a área lateral da estaca $\left(\sigma_{\mathrm{h}}^{\prime}=\mathrm{K}_{\mathrm{h}} \cdot \sigma_{\mathrm{V}}^{\prime}\right)$; deste modo, a tensão tangencial $\left(\tau_{\mathrm{s}}=\sigma_{\mathrm{h}}^{\prime} \cdot \operatorname{tg} \delta\right)$ resistente deve ser aumentada. Em estacas tracionadas, as tensões cisalhantes devem diminuir as tensões verticais efetivas do solo ao redor da estaca e, conseqüentemente, o atrito lateral na estaca tracionada deve ser menor do que o atrito na mesma estaca comprimida.

Já MELO (1982b) argumentou que na interface solo-estaca, quando a estaca é sujeita ao arrancamento, a tensão vertical efetiva deve ser menor que a pressão de terra, porque parte do peso do solo é transportado pela estaca. Por outro lado, se a estaca é sujeita à compressão, a tensão vertical deve ser maior que a pressão de terra. Segue-se que o atrito lateral sob carga de tração é menor que o atrito lateral sob carga de compressão. 
Quanto ao valor a se utilizar de atrito lateral à tração, em relação ao de compressão, MANSUR \& KAUFMAN (1956) encontraram, para estacas cravadas em areia densa e areia fina a média, razões de 0,80 e 0,83 , respectivamente. McCLELLAND (1972) aconselhou adotar um valor de 0,7. Todavia, IRELAND (1957), VÉSIC (1970) e ISMAEL \& KLYM (1979) afirmaram que aqueles atritos são iguais entre si. POULOS \& DAVIS (1980) sugeriram considerar, para o atrito lateral à tração, valor próximo a $2 / 3$ daquele considerado para estacas sujeitas à compressão, valor também indicado pelo NAFVAC/DM-7 (1982) apud PRAKASH (1990), em solos não coesivos.

ORLANDO (1985) concluiu que a redução da resistência lateral à tração, em tubulões retos, é da ordem de $45 \%$, embora tivesse realizado várias suposições no tocante aos parâmetros do solo e da fundação, tais como no coeficiente de empuxo horizontal (igual à relação entre os pesos específicos do concreto em relação ao do solo), na adesão estaca-solo, no ângulo de atrito estaca-solo e na tensão vertical junto à estaca, cujas variações podem levar a valores não muito precisos.

CARVALHO et al. (1991) obtiveram, para estacas tipo raiz, ensaiadas no Campo Experimental da USP em São carlos, atrito lateral à tração correspondente a $84 \%$ daquele encontrado à compressão, não obstante AZEVEDO Jr. (1991) ter encontrado uma razão de $60 \%$ entre esses atritos, em solo residual de São Paulo, também para estacas raiz.

LEHANE et al. (1993) concluíram que a carga lateral à tração é $20 \%$ menor que à compressão. De NICOLA \& RANDOLPH (1993) relataram que em solos finos, onde o carregamento pode ser considerado não drenado, a carga lateral última é geralmente tomada igual, em tração e compressão. Contudo, em solos não coesivos ou drenados, tem sido costume até recentemente considerar menor atrito lateral sob carga de tração, que sob carga compressiva. Por exemplo, nos métodos de projeto revistos poor BERINGEN et al. (1979), para estacas cravadas em areia densa, préadensadas, a razão do atrito lateral à tração e à compressão variou entre 0,65 e 0,76, com uma média de 0,7 .

Segundo De NICOLA \& RANDOLPH (1993), a justificativa para se adotar menor atrito lateral em tração que à compressão vêm de ensaios de campo conduzidos principalmente nas décadas de 60 e 70 . Instrumentação ao longo do fuste da estaca e na ponta foram utilizados para diferenciar entre atrito lateral e de ponta, 
em ensaio à compressão. Em muitos casos, a instrumentação foi somente religada após a instalação da estaca, ignorando, desse modo, tensões residuais aprisionadas dentro do sistema estaca-solo. Como relatado por HOLLOWAY et al. (1978), isto deve conduzir a subestimação da componente de ponta e superestimação da componente lateral da carga última total da estaca. Este fato foi considerado como o principal motivo para o maior atrito lateral observado em carregamento compressivo, comparado ao tracionado.

De NICOLA \& RANDOLPH (1993) afirmaram que para a grande maioria dos casos, o debate sobre a magnitude relativa da atrito lateral lateral para os dois tipos de carregamento é secundário, pois há incerteza geral na previsão da capacidade de carga de estacas em areias. Isto é refletido em recentes contribuições que não têm diferenciado entre carregamento à tração e à compressão, quando da determinação carga lateral, aceitando que os dados de ensaios de provas de carga são insufuicientes para dar tal nivel de refinamento.

Bases teóricas podem tentar explicar qualquer diferença entre capacidade lateral à compressão e à tração. Mecanisnos potenciais para tais diferenças incluem:

1. O coeficiente de Poison de expansão e contração do fuste da estaca $\left(v_{\mathrm{p}}\right)$, conduzindo a mudanças nas tensões efetivas radiais no solo, em volta da estaca, resultantes da mudança do diâmetro da estaca;

2. Diferenças na tensão total de campo, com carregamento compressivo tendendo ao aumento e carregamento de tração tendendo ao decréscimo do nível de tensões principais no solo;

3. Mudanças nas tensões efetivas principais, devida a rotação das direções das tensões principais. Dependendo das tensões residuais de campo ao longo do fuste da estaca, o grau de rotação das tensões principais variará com o sentido do carregamento. Este último mecanismo tem sido notado em instrumentação de campo

Segundo esses autores, sob carregamento à tração, há uma tendência para as tensões radiais atingir um valor máximo, quando a ruptura aproxima-se. Isto porque a força total aplicada alcança um valor fixo na ruptura. Por outro lado, sob compressão, a carga da estaca continua a aumentar, mesmo que a ruptura ao longo do fuste tenha ocorrido, devido a carga adicional existente, produzida pela ponta. Justifica-se, então, valores mais elevados das tensões radiais próximas à superficie. 
A razão entre a tensão radial final e a inicial é sempre maior que a unidade em compressão, e menor que a unidade em tração. O máximo valor da razão do atrito lateral à tração e à compressão ocorre para estacas rijas e há uma tendência para a razão decrescer com o aumento da compressibilidade da estaca.

De NICOLA \& RANDOLPH (1993) concluiram que uma função quadrática apropriada, relacionando a razão entre os atritos laterais à tração e à compressão, pode ser ajustada. Isto conduz a uma expressão final para a razão entre os atritos laterais igual a :

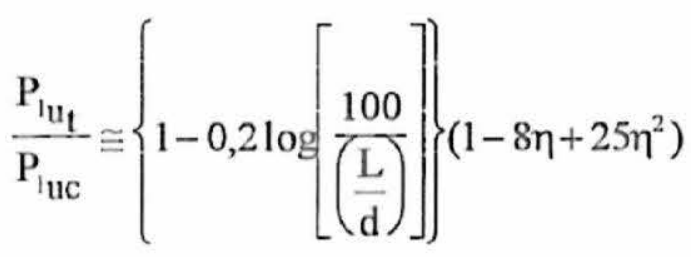

onde $\eta=v_{p} \tan \delta(L / d)\left(G_{m} / E_{p}\right)$

em que $\mathrm{G}_{\mathrm{m}}$ = módulo cisalhante médio do solo, na região de embutimento da estaca;

e $\quad \mathrm{E}_{\mathrm{p}}=$ módulo de elasticidade da estaca.

RAO \& VENKATESH (1985) realizaram ensaios de laboratório em estacas de aço brando $(\mathrm{D}=12,7 \mathrm{~mm}$ e $\mathrm{L}=320 \mathrm{~mm})$, de superficies lisas e rugosas, em areias uniformes, em condições seca e submersa, com compacidade fofa e densa. Afirmaram que a capacidade ao arrancamento aumentou com L/D, com a rugosidade da estaca, densidade do solo e tamanho das particulas.

Esses autores verificaram também que deslocamentos das estacas iguais a $5 \mathrm{e}$ $10 \%$ do diâmetro, em média, em areias secas, fofas e densas, respectivamente, mobilizaram a capacidade ao arrancamento. Cerca de 3 a $6 \%$ do diâmetro das estacas foram requeridos para mobilizar as cargas laterais, durante ensaios de compressão, em areias densas. Observaram que os atritos laterais unitários durante ensaios de tração são significantemente menores que durante ensaios de compressão, especialmente no caso de estacas rugosas de compressão, para as quais ele é $80 \%$ menor e para estacas lisas, são 10 a $50 \%$ menores. Concluíram que a submersão da areia resultou em redução da capacidade ao arrancamento. 


\subsection{Influência do Tempo de Carregamento em Provas de Carga e de Recarregamentos em Fundações Tracionadas e Comprimidas}

Segundo FERREIRA \& LOPES (1985), freqüentemente necessita-se realizar provas de carga, para confirmar previsões ou mesmo determinar a capacidade de carga e os recalques de fundações. A interpretação dessas provas, entretanto, não é muito simples, uma vez que o tempo (ou velocidade) e o modo de carregamento têm influência nos resultados. Em carregamentos envolvendo apenas crescimento da carga, o modo de carregamento (se contínuo ou em estágios) não é muito importante; já a velocidade com que a carga é incrementada, ou o tempo em que os estágios são mantidos, tem uma importância considerável.

Existem diversos procedimentos para a aplicação da carga estática à estaca. $\mathrm{O}$ mais empregado é o carregamento lento em estágios (ou SML - Slow Maintened Load). Não obstante sua grande aceitação, este método conduz a tempos muito longos, exigindo leituras demoradas. Por isso há o carregamento rápido em estágios (ou QML Test- Quick Maintened Load Test), em que a prova de carga necessita de poucas horas para ser concluida.

O carregamento lento em estágios é padronizado, no Brasil, pelo MB3472/1991, da ABNT. É preconizado que o carregamento dar-se-á em estágios iguais e sucessivos, sendo a carga aplicada em cada estágio, não superior a $20 \%$ da carga de trabalho prevista para a estaca ensaiada. A estaca é carregada até a ruptura ou até duas vezes o valor previsto para a carga de trabalho. Em cada estágio, a carga deve ser mantida até a estabilização dos deslocamentos, e no mínimo, por 30 minutos. Os deslocamentos são lidos, em cada estágio, a partir do tempo da aplicação instantânea da carga $(\mathrm{t}=0 \mathrm{~min}$.), passando pelos tempos de $2 \mathrm{~min}$., 4, 8, 15 e $30 \mathrm{~min}$, e daí, a cada 30 min., até atingir a estabilização, admitida ocorrer quando a diferença entre as leituras realizadas em tempos " $\mathrm{t}$ " e " $\mathrm{t} / 2$ " correspondem a, no máximo, $5 \%$ do deslocamento ocorrido no mesmo estágio. O descarregamento deve ser feito no mínimo, em quatro estágios, por tempo não inferior a $15 \mathrm{~min}$., com os critérios de estabilização de recalques iguais ao do carregamento.

O carregamento rápido em estágios também é normalizado pelo MB-3472/91, da ABNT. Neste ensaio, o carregamento é feito em estágios iguais e sucessivos, observando-se que a aplicação das cargas é independente da estabilização das 
deformações. Cada estágio corresponde a $10 \%$ da carga de trabalho prevista, sendo mantida a carga durante $10 \mathrm{~min}$. Os deslocamentos são lidos no início de cada estágio (leitura instantânea), após 2,5, 5,0 e $10 \mathrm{~min}$. (fim do estágio). Finda a estabilização, encerra-se o ensaio, efetuando-se o descarregamento em 04 estágios, cada um mantido por $05 \mathrm{~min}$., com as leituras dos respectivos deslocamentos, no início e no final de cada estádio. Após $10 \mathrm{~min}$. do descarregamento total, faz-se a leitura final do deslocamento.

FELLENIUS (1975) sugeriu a realização do ensaio rápido em 20 estágios, cada um da ordem de $15 \%$ da carga de trabalho prevista, com manutenção da carga por 15 minutos e leituras dos deslocamentos de 3 em 3 minutos.

REESE et al. (1969) realizaram ensaios à compressão em estacas escavadas, de $50 \mathrm{~cm}$ de diâmetro e $9 \mathrm{~m}$ de comprimento, em solo argiloso. Concluiram que os ensaios rápidos conduziram a maior carga na ponta, que os outros ensaios convencionais.

ADAMS \& RADHAKRISHNA (1971) relataram que houve uma significativa redução na carga última ao arrancamento de fundações escavadas cilindricas e em forma de "sino" (base alargada), em argila fissurada do Lago Eire, Canadá, comparando-se os ensaios de tempo rápido e lento, respectivamente. No caso de fundações em forma de sino, a carga última com longa duração variou de 50 a $70 \%$ a menos da de curta duração, aumentando com a profundidade da fundação. A redução na carga última ao arrancamento, sob cargas mantidas por longos tempos, é máxima para fundações em profundidades rasas, devido o efeito da superficie de contorno e a tendência para fissuras abrirem-se sob tração. Este efeito decresce com a profundidade e teoricamente, para L/D igual a 5, não deve haver mudanças entre as condições de curta duração e longa duração.

RADHAKRISHNA \& ADAMS (1973) concluiram que para a mesma argila fissurada supra-citada, houve uma redução de $50 \%$ na resistência à tração de tubulões sem base alargada, passando de carregamento rápido (temporário) para permanente.

SACILOTTO (1992), ao analisar provas de carga em estacas instrumentadas sujeitas à compressão, no Campo Experimental de Fundações da USP/São Carlos, chamou a atenção para o fato de que, quando foram superpostos num mesmo gráfico os diagramas de uma prova de carga rápida e outra lenta, com a mesma origem, na 
mesma estaca, notou-se que para um mesmo deslocamento, os valores das cargas foram maiores para a prova de carga rápida. Este fato fora constatado também por BJERRUM (1973), DANZIGER (1983), MATOS \& MILITITSKY (1990), e MILITITSKY (1991), sendo que este último relacionou o fenômeno em questão, pelo aumento ou diminuição da rigidez solo-estaca, conforme haja altas ou baixas velocidades de carregamento, respectivamente.

Entretanto, SACILOTTO (1992) demonstrou que para estacas com resistências de ponta mobilizadas ou próximas da mobilização, não há diferenças significativas entre as curvas carga $\mathrm{x}$ recalque, das provas de carga rápida e lenta. Opinião também compartilhada por MATOS (1989), que verificou que a resistência total ao arrancamento, em estacas brocas não experimentou alteração significativa, com a mudança da metodologia de carregamento. SACILOTTO (1992) também concluiu que, para provas de carga com carregamento rápido, possuindo um maior número de estágios do que as de carregamento lento, permitem obter uma melhor definição da curva carga $\mathrm{x}$ recalque, haja vista a maior quantidade de pontos disponiveis.

Quanto ao efeito do recarregamento em estacas comprimidas, DÉCOURT (1991) afirmou que tensões residuais permanecem na ponta de estacas previamente carregadas, tanto estatica (através de provas de carga) quanto dinamicamente (estacas cravadas).

Em estacas instrumentadas, previamente carregadas, o atrito lateral medido em provas de carga ( $\mathrm{P}_{\text {lumed. }}$ ) e a carga de ponta $\left(\mathrm{P}_{\text {pumed. }}\right)$ não são os valores reais. Se $\mathrm{P}_{\text {pres. }}$ é a carga residual agindo na ponta da estaca, a carga lateral real é obtida

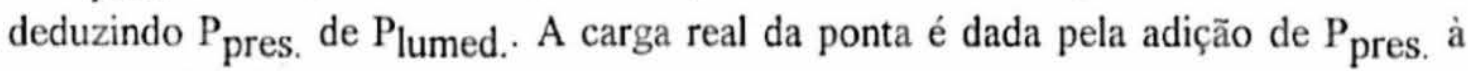
carga medida de ponta $\left(\mathrm{P}_{\mathrm{pmed}}\right)$. Em outras palavras:

$$
\begin{aligned}
& \mathrm{P}_{\mathrm{I}_{\mathrm{u}_{\text {real }}}}=\mathrm{P}_{\mathrm{I}_{\mathrm{u}_{\text {med. }}}}-\mathrm{P}_{\text {pres. }} \\
& { }_{\mathrm{P}_{\mathrm{p}_{\text {real }}}}=\mathrm{P}_{\mathrm{P}_{\mathrm{u}_{\text {med. }}}}+\mathrm{P}_{\text {pres. }}
\end{aligned}
$$

Uma significativa carga residual de ponta pode existir em areias, uma vez que as cargas de ponta são maiores e pequenos deslocamentos são precisos para mobilizar a transferência de atrito lateral. Para uma dada condição de solo, tensões residuais aumentam quando a rigidez da estaca decresce. Portanto, elas aumentam com o 
aumento do comprimento da estaca e o decréscimo na seção transversal e o módulo da estaca.

Para se determinar a tensão residual numa estaca comprimida, pode-se recorrer a uma prova de carga à tração ou realizar outro ensaio de compressão, na mesma estaca. Após a análise de nove provas de carga, DÉCOURT (1991) concluiu que após o primeiro ensaio, a carga medida transferida ao solo, até uma carga igual à máxima carga alcançada no ensaio prévio, parece ser mobilizada exclusivamente por atrito lateral. O mesmo acontece com um terceiro carregamento, em comparação com o segundo carregamento. A carga lateral medida no segundo ou terceiro ensaio, é, na realidade, a carga última lateral mais a carga residual na ponta da estaca causada pela prova de carga prévia. Este fato foi comum a todas as estacas analisadas.

HOLLOWAY et al. (1978), apud De NICOLA \& RANDOLPH (1993), propuseram que as tensões residuais reais presentes após a instalação da estaca podem ser estimadas pela condução de um ensaio de carregamento à tração, diretamente após o ensaio de compressão.

MANTILLA (1992), realizando provas de carga no Campo Experimental de Fundações da USP/São Carlos, concluiu que à medida que uma estaca escavada vai sendo introduzida no terreno, por meio de sucessivas provas de carga, ela passa a se comportar como uma estaca cravada, devido o aumento de resistência e diminuição de compressibilidade do solo, sob a ponta da estaca. TEIXEIRA (1993), reensaiando as mesmas estacas analisadas por MANTILLA (1992) e SACILOTTO (1992), chegou às mesmas conclusões.

MATOS (1989) realizou provas de carga em estacas escavadas de pequeno diâmetro, embutidas em areia silto-argilosa, no Campo Experimental de Cachoeirinha, RS. Concluiu que, para a mesma metodologia de carregamento, os deslocamentos de uma determinada estaca tracionada são maiores no reteste do que no primeiro teste, e que o fato de uma estaca não ser previamente levada à ruptura por compressão, antes do ensaio de arrancamento, pode conduzir a um aumento da resistência total de arrancamento.

DANZIGER (1983) executou várias provas de carga em tubulões e sapatas, em um terreno constituído de uma camada de solo residual, caracterizado por uma argila silto-arenosa, sobrejacente a uma de areia silto-argilosa, em Adrianópolis, RJ. 
Reensaiando uma sapata à tração, observou que a carga de ruptura no reteste foi ligeiramente inferior àquela verificada no primeiro teste e que o reteste apresentou deslocamentos bem maiores, para os mesmos valores de carga, em relação ao primeiro teste.

\subsection{Efeito da Inundação de um Solo Colapsível na Capacidade de Carga de Estacas Submetidas a Esforços de Compressão e Tração}

\subsubsection{Generalidades}

Na literatura geotécnica, pouco se conhece sobre o efeito da inundação de um solo colapsível, em fundações tracionadas. No Brasil, poder-se-ia citar apenas os trabalhos de CARVALHO \& SOUZA (1990) e CARVALHO \& ALBUQUERQUE (1994), ambos no Campo Experimental de Fundações da UNESP/Ilha Solteira, em estacas escavadas de $6 \mathrm{~m}$ de comprimento e $0,25 \mathrm{~m}$ de diâmetro, que serão melhor detalhados adiante.

Em vista disso, recorreu-se aos trabalhos de vários autores, em estacas comprimidas, embutidas em solos colapsiveis, a fim de poder melhor entender-se o comportamento de fundações, notadamente estacas, quando o solo sofre algum processo de acréscimo do grau de saturação $(\mathrm{Sr})$, seja por processos artificiais, através da abertura de cavas (complementadas ou não por drenos verticais), em torno do topo das estacas, que são preenchidas por água, seja por acidentes casuais, como o rompimento de uma linha de bueiros, ou de adutora, e.g.

\subsubsection{Processos de Inundação das Camadas Colapsíveis}

O processo de inundação do terreno, visando a obtenção do aumento do grau de saturação do solo, tem merecido o estudo de diversos autores. Procura-se alcançar, tanto quanto possivel, as condições reais que uma fundação estará submetida, quando da eventualidade de uma inundação indesejada do solo colapsível.

O caráter colapsível de um solo fica bastante evidenciado, quando se utilizam provas de carga em placas ou em estacas, e mantendo-se uma carga constante 
(geralmente a carga de trabalho), constatam-se recalques abruptos, devido a inundação do solo. De fato, os ensaios in situ, apesar de mais onerosos, traduzem melhor o comportamento da interação fundação-solo, pois são efetuados em verdadeira grandeza e com o solo em seu estado de tensões e deformações praticamente original, o que diminue o número de variáveis e de situações hipotéticas na análise daquele comportamento.

NADEO \& VIDELA (1975a, b) realizaram várias experiências de inundação de um solo colapsível, na cidade de Córdoba, Argentina, a fim de verificar o comportamento de duas estacas comprimidas e uma tracionada. Compararam a inundação do terreno através de uma cava, em torno do topo da estaca, com a abertura de 04 furos verticais, preenchidos por brita. Efetuaram a inundação em diversas etapas, começando primeiramente ora pela base da estaca, ora pelo fuste, ou então, por ambos ao mesmo tempo, alterando várias vezes o carregamento aplicado em cada etapa, até a ruptura da ligação estaca-solo.

NADEO \& VIDELA (1975b) obtiveram o valor médio de $\mathrm{S}_{\mathrm{r}}$ em torno de $80 \%$, ao longo do fuste de uma estaca ensaiada à compressão e outra à tração, utilizando-se tubos perfurados. Em outra estaca ensaiada à compressão, utilizando apenas uma cava, o grau de saturação atingiu 100\% nos primeiros $4 \mathrm{~m}$. Os autores concluiram que o uso de tubos perfurados não produziu os resultados esperados, em relação aos obtidos pela abertura de cavas, em torno do topo das estacas.

GRIGORYAN \& KHABIBULLIN (1980) realizaram provas de carga em estacas escavadas, contando para a inundação com a abertura de cava de $2 \times 2 \mathrm{~m}$, por 0,6 $\mathrm{m}$ de profundidade, em torno da cabeça da estaca, bem como a utilização de 4 drenos, com 0,15 m de diâmetro, preenchidos com pedregulho. A inundação começou 20 dias antes dos ensaios, pelo topo e pela base da estaca, e prosseguiu até o fim do ensaio, 5 dias após, concluindo que, a esta altura, o $S_{r}$ do solo situou-se entre 80 a $90 \%$.

ARUTYUNOV et al. (1983), realizando provas de carga à compressão em estacas, com o solo colapsível inundado, através de uma cava e 04 poços de drenagem, observaram que $\mathrm{S}_{\mathrm{r}}$ excedeu ligeiramente a $80 \%$, até uma profundidade de $28 \mathrm{~m}$. 
CARVALHO \& SOUZA (1990) utilizaram uma cava de $1,2 \times 1,2 \mathrm{~m}$, em planta, por 0,6 $\mathrm{m}$ de profundidade, para inundação de estacas escavadas comprimidas e tracionadas, em Ilha Solteira, SP.

LOBO (1991) utilizou uma cava, de $1,3 \mathrm{~m}$, em planta, com 0,40 $\mathrm{m}$ de profundidade, complementada por 4 drenos verticais, de $0,10 \mathrm{~m}$ de diâmetro $\mathrm{e}$ comprimento próximo ao comprimento das estacas ensaiadas, em Bauru, SP.

TEIXEIRA (1993) também utilizou uma cava com 1,4 x 1,4 m, em planta, por $1,1 \mathrm{~m}$ de profundidade, juntamente com 4 drenos de 0,15 de diâmetro e $10 \mathrm{~m}$ de profundidade, preenchidos com areia limpa, no solo colapsível de São Carlos.

CARVALHO \& ALBURQUEQUE (1994) utilizaram uma cava e 4 drenos, inundando o solo $120 \mathrm{~h}$ antes da realização da prova de carga, em estaca tracionada, em Ilha Solteira.

Quanto à eficiência da inundação do terreno, muitos autores têm afirmado que nem sempre as condições reais de campo são verdadeiramente alcançadas, utilizandose as técnicas acima descritas.

Com efeito, REZNIK (1993) citou que as técnicas de saturação utilizadas em ensaios de placas em solo colapsivel, no campo, não atingem as mesmas condições de umidade criada em oedômetros. Em um dado experimento, a autor relatou que o grau de saturação encontrado no oedômetro foi de $90-92 \%$, maior que o determinado para condições de campo (70-80\%). Engenheiros da ex-URSS acreditam que valores de potencial de colapso obtidos em oedômetros devem ser verificados por ensaios de placa. É sabido que o potencial de colapso varia com o grau de saturação. O Código de Construções da ex-URSS não considera loesse e "loams" loésicos como colapsíveis, quando o grau de saturação in situ excede 80\%. A esse respeito, VARGAS (1992) afirmou que em camadas colapsíveis, existe a hipótese de que sob pressão de terra natural ou sob pressão muito elevada, não há ocorrência de colapso do solo. Em solos brasileiros, essa pressão limite é da ordem de $500 \mathrm{kPa}$. Em outras palavras, se se aplica essa carga ao solo colapsivel, há, naturalmente, a evolução de recalques até sua estabilização; entretanto, após essa carga, é possivel saturar à vontade o solo, que a inundação não exerceria o menor efeito sobre os recalques. 
Ainda de acordo com RESNIK (1993), as condições de umidade desenvolvidas durante provas de carga em placas em loesses e "loams" loésicos saturados são semelhantes àquelas observadas sob fundações de estruturas, quando um rápido aumento de recalques é causado por inundação descontrolada de solos. Em provas de carga, o valor máximo de carga correspondente à parte linear da curva carga-recalque, denominado limite de proporcionalidade, $\mathrm{P}_{\mathrm{pr}}$, decresce quando o teor de umidade aumenta. Teoricamente, o valor mínimo de $\mathrm{P}_{\mathrm{pr}}$ seria observado quando o grau de saturação alcança $100 \%$. Na realidade, a completa saturação do solo ocorre quando a causa da infiltração de água não é eliminada imediatamente. Na experiência do autor, o grau de saturação dos solos sob estruturas, devido a inundação acidental, nunca excedeu $70-80 \%$. Em adição, o conhecimento de $\mathrm{P}_{\mathrm{pr}}$ é necessário para a correta avaliação do potencial de colapso determinado em laboratório; se uma carga aplicada excede $\mathrm{P}_{\mathrm{pr}}$, a validade de ensaios de oedômetros tornam-se questionáveis.

KRUTOV et al. (1980) relataram que é errôneo acreditar que a compressibilidade de solos loésicos aumenta com o aumento de seu teor de umidade e alcançam um máximo valor sob completa saturação. Os autores ensaiaram amostras de solo, desde a umidade natural até completa saturação. Concluiram, então, que o colapso máximo do solo não ocorre para completa saturação, mas em um certo teor de umidade menor, no qual condições críticas são criadas. Esse teor de umidade é próximo ao teor de umidade do limite plástico $\left(w_{p}\right)$ e varia de $(0,92$ a 1,3$) w_{p}$. A pressão mínima inicial de colapso também não é observada para completa saturação, mas para um menor teor de umidade. Quando o teor de umidade aumenta, a pressão inicial de colapso primeiramente decresce e então, tendo alcançado um valor mínimo, começa a aumentar, quando o teor de umidade aumenta até total saturação.

Os autores afirmaram que freqüentemente evidencia-se que o colapso do solo é menor no caso da elevação do nível de água subterrânea que no caso de inundação pelo topo do terreno. Na elevação do nível de água, o teor de umidade do solo aumenta até a total saturação, o que evita a completa manifestação do colapso do solo. Em inundação pelo topo do maciço, especialmente em massas estratificadas, o grau de saturação geralmente não aumenta até total saturação e o colapso do solo alcança grandes valores. O efeito do grau de saturação dos solos na colapsibilidade pode explicar a ocorrência de colapso após o rebaixamento do nível d'água. Neste caso, a diminuição do teor de umidade do solo e a ocorrência de condições mais favoráveis para sua consolidação causam recalques adicionais. 
GRIGORYAN \& CHINENKOV (1994) analisaram o efeito da inundação no colapso de camadas de solo loésico, na Rússia e Ucrânia, pela abertura de uma cava, de grandes dimensões, cujo lado era igual à espessura da camada colapsivel. Para acelerar a inundação, drenos verticais foram construídos, preenchidos por brita. Os autores concluíram que a inundação por esse processo não reflete a peculiaridade da deformação do solo, observada sob estrutura real. Isto deve-se ao fato de que pequenos tempos de ensaios, aliados a grande consumo de água, gasto para a inundação, bem como a construção de furos drenantes, aumentam grandemente a taxa de água infiltrada no solo e não condizem, necessariamente, ao verificado realmente na prática.

Finalmente, EL-EHWANY \& HOUSTON (1990) relataram que a qualidade de previsão de recalques por colapso depende de uma estimativa acurada da profundidade da zona úmida. A influência combinada de sucção e gradiente de gravidade causa movimento de umidade (infiltração) através de solos parcialmente saturados. Quando a água está armazenada no nível do terreno, a infiltração é ilimitada e uma frente de umidade está ainda moderamente próxima à fonte de água, e, assim, o solo acima da frente de umidade tipicamente tem um grau de saturação maior que $50 \%$. Neste caso, a influência da gravidade pode ser dominante porque a sucção do solo é pequena. Em solo muito seco, contudo, a sucção domina o fluxo e o termo da gravidade torna-se tão negligenciável, que talvez é inadequada para uso na equação do fluxo. Durante a infiltração da água armazenada na superficie, há uma zona de transição próxima à frente de umidade, onde o gradiente, em potencial total, é muito alto. Assim, o processo de infiltração é caracterizado por frentes relativamente rápidas de movimento de água quando a fonte de água é ilimitada e a frente de umidade está ainda razoavelmente próxima da origem. A rapidez da frente úmida está também relacionada ao teor de umidade inicial do solo (sucção) e o tipo de solo.

Ensaios de infiltração unidimensional foram realizados no laboratório para determinar as caracteristicas do fluxo parcialmente saturado, para os solos do campo. Realizaram-se também ensaios de infiltração no campo, para obter as características de migração de umidade, pela infiltração de água em solos inicialmente muito secos. Esses ensaios podem ser a maneira mais prática para estimar a infiltração de depósitos de solos colapsíveis. A taxa de propagação da frente úmida, como função do tempo, pode ser conhecida para o ensaio de infiltração de campo, e esta relação deve ser usada diretamente para estimar a extensão da zona úmida, dada uma certa quantidade 
de água armazenada. O ensaio de infiltração é simples para ser realizado e pode dar boa informação para previsão da extensão de umedecimento por um custo muito baixo.

Os autores sugeriram os seguintes procedimentos para a realização de ensaio de infiltração no campo, em depósitos de solo colapsível, onde, porventura, fundações possam estar assentes:

1. Determinar a maior quantidade de água que deve eventualmente ser armazenada próxima à fundação (isto é, runoff de 100 anos de chuva, a ruptura de uma linha de irrigação por 24 ou $48 \mathrm{~h}$, ou algum outro tipo similar de estimativa);

2. Armazenar esta quantidade de água em uma área representativa, de 10-30 $\mathrm{m}^{2}$, de tal sorte que permita que a água percole dentro da camada subjacente;

3. Fazer amostragem do solo sob e em volta da área armazenadora de água, para determinar a profundidade e extensão lateral da migração de água;

4. Criar uma função da extensão vertical da zona úmida versus tempo de infiltração. Esta função pode ser usada para estimar a extensão de umedecimento para a situação descrita no primeiro passo, ou ela deve ser extrapolada para avaliar até longos períodos de infiltração superficial, se necessário.

\subsubsection{Redução da Carga Última Devida a Inundação do Terreno}

MONTEIRO (1985) e MELLIOS (1985) analisaram provas de carga em estacas brocas, à compressão e à tração, realizadas pela CESP nas Usinas de Ilha Solteira e Jupiá, no Noroeste paulista. As estacas tiveram seus furos abertos mecanicamente, sendo moldadas in loco (acima do N.A.), com lançamento de concreto da superfície e apiloamento discreto, com comprimentos de 3,5 e $5,0 \mathrm{~m}$, e diâmetros de 0,25 e 0,30 m, ou seja, com L/D iguais a 14 e 16,7, respectivamente. Os ensaios de laboratório em amostras de solos coluvionares determinaram um potencial de colapso de até $6 \%$, quando da inundação das mesmas. Ensaiaram as estacas comprimidas com o solo em estado natural e inundado.

Os autores demonstraram que cerca de $80 \%$ da carga última fora absorvida pela resistência lateral, não obstante considerar valores iguais de atritos laterais à tração e compressão. Ademais, concluiram que houve uma redução em torno de $50 \%$ 
na capacidade de carga de estacas comprimidas, devida a inundação. O atrito lateral médio (carga última dividida pela área lateral da estaca) à tração das estacas foi de 29 e $16,7 \mathrm{kPa}$, para L/D de 14 e 16,7, respectivamente.

CARVALHO \& SOUZA (1990) realizaram duas provas de carga em placas e quatro em estacas, sendo duas sujeitas à compressão e duas à tração. As estacas foram moldadas in loco, com comprimentos de $6 \mathrm{~m}$ e diâmetros de $0,25 \mathrm{~m}$ (L/D = 24), e concretagem efetuada logo após a abertura do furo, sendo o concreto discretamente apiloado. Como enfatizado pelos autores, o potencial de colapso da camada coluvionar é de $6 \%$.

As provas de carga em placas foram efetuadas a $0,60 \mathrm{~m}$ da superficie do terreno, com o solo em estado natural e, posteriormente, inundado. Esta metodologia também foi adotada para as provas de carga nas estacas. Os autores constataram o colapso do solo, pela prova de carga na placa, bem como a ruptura da ligação soloestaca, tanto em estacas comprimidas, quanto nas tracionadas, para uma carga correspondente a $1 / 3$ da carga de ruptura (prova de carga com umidade natural). Em outras palavras, a redução da carga última provocada pela inundação do solo foi de $66 \%$. CARVALHO \& SOUZA (1990) encontraram atrito lateral médio de 29,1 kPa, para a estaca tracionada.

Da mesma forma, SILVA (1990) analisou os resultados de três provas de carga à compressão sobre estacas de pequeno diâmetro, em solo colapsível, no projeto Perimetro de Irrigação Formoso "A", na cidade de Bom Jesus da Lapa (BA). Dados de laboratório acusaram um potencial de colapso de amostras do solo entre $2 \mathrm{e}$ $4 \%$, na saturação. Todas as estacas foram escavadas por trado manual, possuindo 2,5 $\mathrm{m}$ de comprimento, por $0,102 \mathrm{~m}$ de diâmetro, totalmente embutidas na camada colapsível, considerada possuir entre 6 a $8 \mathrm{~m}$ de espessura. O concreto utilizado na confecção das estacas foi vibrado.

Para facilitar a infiltração da água no terreno, foi efetuado um furo inclinado, de mesmo comprimento da estaca, mas com menor diâmetro, preenchido por brita. As provas de carga nas estacas foram realizadas sob três condições distintas: solo na umidade natural, inundado previamente $24 \mathrm{~h}$ antes do inicio do ensaio e, finalmente, inundado na carga de trabalho. $\mathrm{O}$ autor concluiu que inundando-se $\mathrm{o}$ solo previamente, a redução da carga última foi de $77 \%$ e, inundando-o na carga de trabalho, a redução caiu para $71 \%$. 
LOBO (1991) apresentou os resultados obtidos em provas de carga à compressão, realizadas em 10 estacas, executadas na cidade de Bauru, SP, sendo 4 escavadas e 6 apiloadas. Nestas últimas, o furo fora aberto por apiloamento do solo. As estacas eram de 2, 4 e $6 \mathrm{~m}$, por $0,25 \mathrm{~m}$ de diâmetro. As provas de carga foram realizadas com o solo em estado natural e inundado, uma vez que ensaios oedométricos haviam acusado caráter colapsível do sedimento superficial.

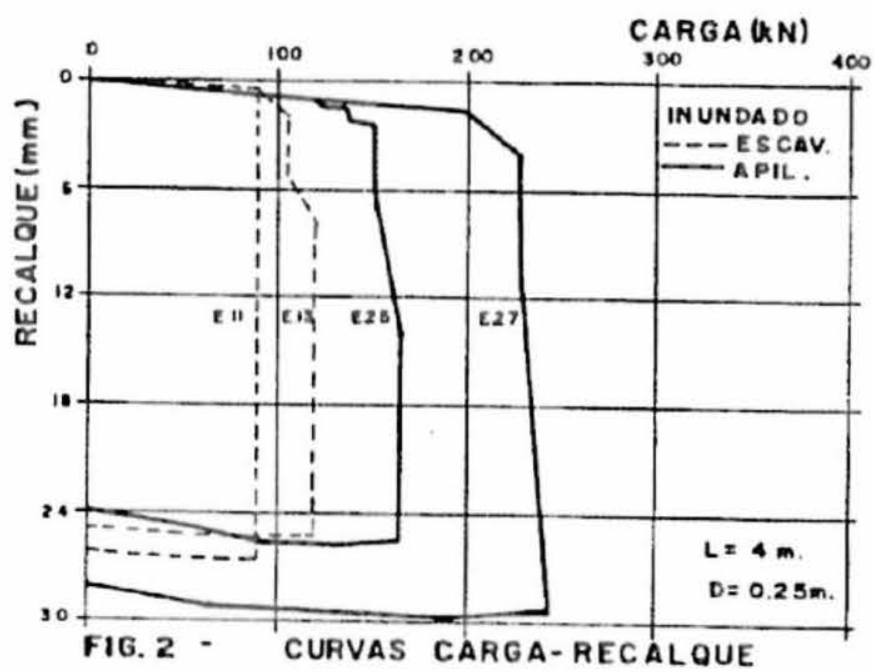

FIGURA 2.11 - Efeito da Inundação do Solo na Carga Última à Compressão de Estacas Escavadas e Apiloadas (LOBO, 1991a).

A Figura 2. 11 mostra algumas das provas de carga realizadas nas estacas escavadas e apiloadas, com o solo em estado natural e inundado.

LOBO (1991) concluiu que as estacas escavadas foram as que apresentaram maior sensibilidade ao efeito da inundação do terreno, com uma redução média no valor da carga última de $40 \%$. Por sua vez, as estacas apiloadas apresentaram uma redução média próxima a $30 \%$.

O autor explicou este fato considerando que, na confecção das estacas escavadas, o solo ao redor do fuste da estaca mantêm-se praticamente em seu estado natural, enquanto que as apiloadas tiveram o solo ao redor do fuste fortemente apiloado, com indice de vazios reduzido, portanto menos susceptiveis de sofrer colapso 
Neste sentido, diversos autores da ex-URSS, tais como GRIGORYAN \& CHINENKOV (1980), ARUTYNOV et al. (1983), IL'ICHEV et al. (1984), GRIGORYAN \& CHAKYVAZDE (1986) e GRIGORYAN \& CHINENKOV (1991), concluiram que o apiloamento do solo loésico colapsível, na região da ponta da estaca, ou mesmo a abertura de furos por apiloamento, para execução de estacas, conduz a significativa melhoria da carga última das estacas. Desse modo, há uma diminuição, ou até mesmo a eliminação da potencialidade de colapso do conjunto estaca-solo.

Se o terreno é constituído por uma espessa camada colapsível, ZARETSKII \& KARABAEV (1987) concluiram que a pressão necessária para início do colapso do solo também aumenta com a profundidade, por causa do menor grau de alteração das camadas subjacentes; como a estaca possui deformações relativamente uniformes em todos os pontos, a incompatibilidade das deformações das camadas superiores e inferiores de solo provoca a mudança no sinal das tensões cisalhantes a partir de uma determinada profundidade. Os valores de atrito negativo, da profundidade de mudança do sinal das tensões cisalhantes e conseqüentemente, do recalque adicional no topo da estaca, dependem do tipo de inundação, das características de resistência e deformação do solo na base da fundação, na umidade natural e após o umedecimento, e ainda, do comprimento, diâmetro e rigidez da estaca. Assim, parece lógico crer que, quanto mais profunda estiver embutida a estaca na camada colapsivel, tanto maior carga será necessária para produzir o colapso da ligação estaca-solo.

Quanto à prevenção de recalques por colapso, há ainda, entre outros, os estudos de SILVEIRA (1957), SOUTO \& SILVEIRA (1963), CINTRA et al. (1986) e de ARAGÃO \& MELO (1982), mostrando que os efeitos do colapso do solo podem ser reduzidos, através da remoção do solo sob a fundação rasa a ser construida e então proceder-se à sua reposição, em camadas compactadas.

AGNELLI (1992) realizou provas de carga diretas no solo superficial de Bauru, SP, de caráter colapsível, conforme já demonstrado por ensaios oedométricos em amostras indeformadas e também através de provas de carga em estacas, analisadas por LOBO (1991). O autor concluiu que a redução da capacidade de carga do solo, devida a inundação, foi mais acentuada para uma maior pressão de inundação e que as reduções da capacidade de carga variaram, na média, entre $52 \%$, na profundidade de $1,0 \mathrm{~m} \mathrm{e} 43 \%$, na profundidade de $2,0 \mathrm{~m}$ do nível do terreno. 
CINTRA (1992) efetuou provas de carga diretas, adotando carregamento rápido e lento, no Campo Experiemental de Fundações da USP/São Carlos, com o solo no estado natural e inundado, na carga de trabalho. Notou-se que nos ensaios inundados, houve redução da capacidade de carga do solo de $50 \%$ e que o ensaio rápido conduziu a maior capacidade de carga do solo, em seu estado virgem. Ademais, recarregamentos sucessivos conduziram ao aumento da capacidade de carga do solo.

TEIXEIRA (1993) também observou redução na carga última de duas estacas escavadas, à compressão, ambas com $10 \mathrm{~m}$ de comprimento e diâmetros de 0,40 e $0,50 \mathrm{~m}$, através de provas de carga realizadas no Campo Experimental de Fundações do Departamento de Geotecnia da USP/São Carlos, em solo inundado. As reduções foram de $34 \%$, na estaca de $0,40 \mathrm{~m}$ de diâmetro e de $28 \%$, na de $0,50 \mathrm{~m}$. O autor também relatou que a aplicação de um fator de segurança convencional de 1,5 sobre a carga de ruptura, estimada através de qualquer metodologia, para o solo em condição de umidade natural, conduz a cargas de trabalho perigosamente próximas às cargas de colapso das estacas, devendo, por isso, ser julgado incoveniente.

CARVALHO \& ALBUQUERQUE (1994) realizaram duas provas de carga à tração, em duas estacas de $6 \mathrm{~m}$ de comprimento e $0,25 \mathrm{~m}$ de diâmetro, em Ilha Solteira. Uma das provas de carga foi realizada com o solo em sua umidade natural, sendo a estaca instrumentada, ao longo de seu fuste. A outra foi realizada após inundação do terreno, por um período de $120 \mathrm{~h}$. A Figura 2.12 apresenta as curvas carga $\mathrm{x}$ deslocamento das duas provas de carga. Os autores concluiram que houve uma redução de $50 \%$ da carga última, pelo efeito da inundação do terreno e que o atrito lateral à tração médio, ao longo de todo o fuste da estaca foi igual a $34,8 \mathrm{kPa}$.

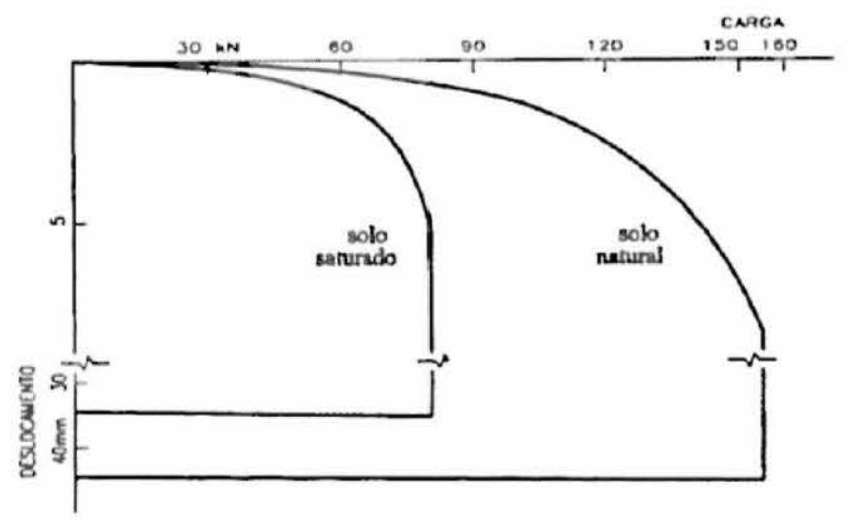

FIGURA 2.12 - Curvas Carga x Deslocamento das Estacas Ensaiadas à Tração (CARVALHO \& ALBUQUERQUE, 1994). 


\section{Capítulo 3}

\section{CAMPO EXPERIMENTAL DE FUNDAÇÕES DA USP/SÃO CARLOS}

\subsection{Generalidades}

A escolha do local, dentro do Campus da USP/São Carlos, para implantação do campo experimental, recaiu nos aspectos de representatividade do perfil geotécnico da região e o nível d'água. Optou-se pelo local que apresentasse os dois horizontes de solo - sedimento cenozóico e solo residual- bem definidos, além de que o nível d'água não interferisse na execução das estacas a serem analisadas. Dai a escolha no extremo sul do Campus. Maiores detalhes da implantação encontram-se em CARVALHO (1991).

\subsection{Caracterização Geotécnica}

Extensa área superficial do Interior paulista é constituída de sedimentos cenozóicos. VILAR (1979) comprovou a colapsibilidade desse sedimento, na cidade de São Carlos. Para que ocorra o colapso desse solo, em sua condição natural, é necessário que esteja umedecido e carregado.

Para a completa caracterização geotécnica do campo experimental, foram realizados diversos ensaios em laboratório e in situ. Dentre esses últimos, realizaramse cinco sondagens de simples reconhecimento (SPT) e cinco ensaios de penetração estática (CPT), até a profundidade de $20 \mathrm{~m}$. Quanto aos ensaios laboratoriais, um poço de $10 \mathrm{~m}$ foi aberto, para retirada de amostras indeformadas, de metro em metro. 
O perfil típico obtido a partir das sondagens indica uma camada superficial de sedimento cenozóico, com $6 \mathrm{~m}$ de espessura. Trata-se de areia argilosa, marrom, laterizada, porosa e colapsível. Separada por uma linha de seixos, situada à profundidade de $6 \mathrm{~m}$, aparece logo abaixo o solo residual do Grupo Bauru, descrito como areia argilosa vermelha. Essas duas camadas apresentam comportamentos distintos, apesar de se encontrarem num mesmo grupo, quando classificadas por sistemas usuais da Mecânica dos Solos (SC, na classificação unificada, e.g.). O nível d'água foi encontrado a $10 \mathrm{~m}$ de profundidade, no inverno (CARVALHO, 1991). A Figura 3.1 apresenta o perfil típico do subsolo do campo experimental (CINTRA et al., 1991).

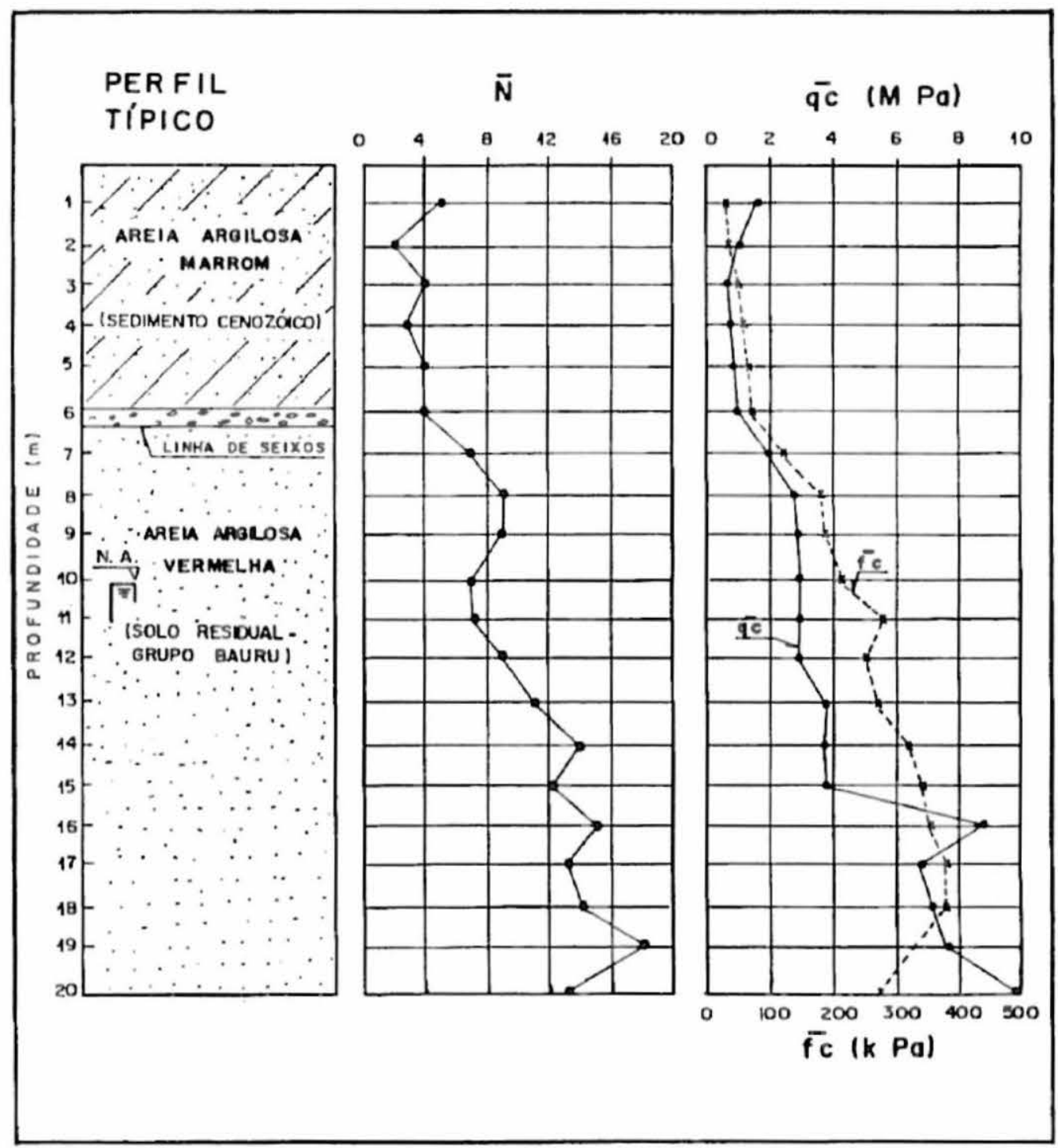

FIGURA 3.1 - Perfil Típico do Campo Experimental de São Carlos (CINTRA et al., 1991). 
A Tabela 5.1 apresenta os parâmetros de resistência desse solo, na área do Campo Experimental de Fundações, obtidos em ensaios laboratoriais, conduzidos por MENEZES (1990).

\subsection{Execução das Estacas Submetidas a Esforços de Tração}

As estacas escavadas foram executadas por meio de trado mecânico helicoidal, de $25 \mathrm{~cm}$ de diâmetro, moldadas in loco. As estacas apiloadas tiveram os seus furos, de $20 \mathrm{~cm}$, abertos por apiloamento do solo, prática comum encontrada no Interior paulista. Após a perfuração, realizou-se a concretagem, com lançamento da superficie e apiloamento discreto do concreto. As estacas do tipo Strauss, com 0,32 m de diâmetro, foram realizadas sem qualquer alteração do procedimento padrão. As estacas escavadas e apiloadas têm $6 \mathrm{~m}$ de comprimento e as do tipo Strauss, $9 \mathrm{~m}$, sendo que $3 \mathrm{~m}$ do fuste desta última estão embutidos no solo residual (Grupo Bauru), que talvez não apresente estrutura colapsível. A disposição dessas estacas, bem como as de reação, encontram-se na Figura 3.2.

Para resistir aos esforços de tração, as estacas foram armadas com barras de aço, em toda sua extensão. As estacas apiloadas e escavadas possuem 4 barras de $12,5 \mathrm{~mm}$ de diâmetro, além de um tirante de $30 \mathrm{~mm}$ de diâmetro, de $1,5 \mathrm{~m}$ de comprimento, utilizado para o arrancamento das mesmas. A estaca do tipo Strauss possui também 4 barras de $12,5 \mathrm{~mm}$, embora tenha sido projetada com dois tirantes de $30 \mathrm{~mm}$ de diâmetro, ancorados $3 \mathrm{~m}$ no interior da estaca, a fim de melhor proceder-se ao arrancamento dessa estaca. A estaca Strauss é instrumentada ao longo de seu fuste, não obstante a transferência de carga medida na prova de carga não ser objeto de estudo, neste trabalho.

\subsection{Execução das Estacas de Reação}

As estacas utilizadas como reação das estacas ensaiadas são do tipo Strauss e raiz. As primeiras possuem $10 \mathrm{~m}$ de comprimento e $0,32 \mathrm{~m}$ de diâmetro, enquanto as últimas têm $16 \mathrm{~m}$ de comprimento e $0,20 \mathrm{~m}$ de diâmetro. Os detalhes construtivos das estacas raizes encontram-se em CARVALHO et al. (1991). 


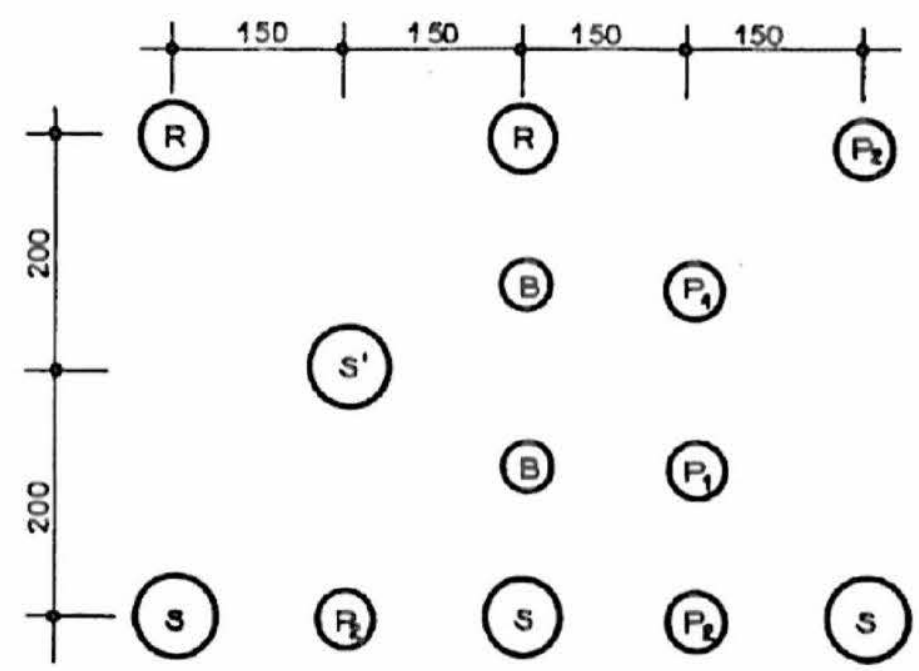

(medidas em $\mathrm{cm}$ )

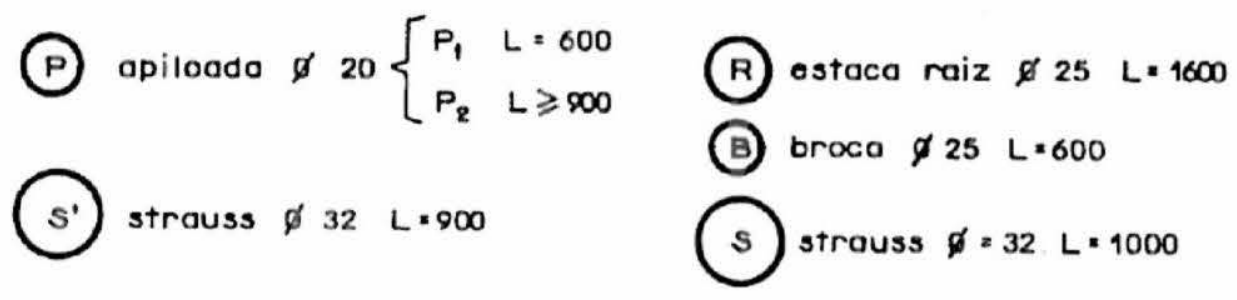

FIGURA 3.2 - Disposição das Estacas Ensaiadas, com as Respectivas Estacas de Reação. 


\section{Capítulo 4}

\section{METODOLOGIA E EQUIPAMENTOS UTILIZADOS NAS PROVAS DE CARGA}

\subsection{Generalidades}

Realizaram-se as provas de carga lentas e rápidas, de acordo com o MB3472/91, mas com o tempo de incremento de carga de $15 \mathrm{~min}$., no ensaio rápido, conforme sugestão de FELLENIUS (1975). As leituras de carga, para cada estágio do ensaio rápido, eram feitas para $0,1,2,3,6,9,12$ e 15 min. Os incrementos de carga se situavam entre $10 \%$ e $20 \%$ da carga de trabalho, conforme o tipo de ensaio, se do tipo rápido ou lento, respectivamente. Esses incrementos davam-se até atingir-se a ruptura da ligação estaca-solo, ou para deformações excessivas não estabilizadas, em torno de $50 \mathrm{~mm}$ (o máximo de deslocamento dos extensômetros mecânicos).

Os descarregamentos foram realizados em apenas dois estágios; nos ensaios rápidos, ao se atingir a carga de ruptura ou a carga máxima, deixou-se de proceder à reposição da carga e aguardou-se o tempo necessário para a estabilização.

\subsection{Equipamentos e Materiais Utilizados}

A seguir, comenta-se um a um, os equipamentos empregados para a realização das provas de carga. Todos eles foram adquiridos na primeira fase do Campo Experimental de Fundações da USP/São Carlos. A Figura 4.1 apresenta o sistema montado para a realização da prova de carga em uma estaca. A Foto 4.1 mostra detalhes dos equipamentos utilizados nas provas de carga. 


\subsubsection{Macaco hidráulico}

Devida a necessidade do transpasse da barra de aço para arrancamento das estacas, o macaco deve possuir um furo central. A capacidade de aplicação de carga do macaco hidráulico utilizado é de $2 \mathrm{MN}$. Devido a grande diferença que se verifica entre a leitura de carga do manômetro e a carga real aplicada - em torno de $20 \%$, de acordo com URTIGÃO (1993), utilizou-se uma célula de carga e um indicador de deformações para as leituras das cargas aplicadas à estaca.

\subsubsection{Célula de carga}

A célula de carga também possui um furo central, para passagem de tirantes. A capacidade de leitura de carga das células empregadas nos ensaios das estacas apiloadas e escavadas é de $200 \mathrm{kN}$ e na do tipo Strauss, de $500 \mathrm{kN}$. Nos anexos A e B são apresentadas as curvas de calibração dessas células de cargas.

\subsubsection{Indicador de deformação}

O indicador de deformações utilizado para leituras das deformações específicas de extensômetros elétricos de resistência, tem capacidade de leitura de \pm $50.000 \times 10^{-6} \mathrm{~mm}$ e, ligado à célula de carga, torna possivel o registro das deformações.

\subsubsection{Extensômetros mecânicos}

Em cada prova de carga, fez-se uso de quatro extensômetros mecânicos, com precisão de $0,01 \mathrm{~mm}$ e curso total de $50 \mathrm{~mm}$. Para traçado da curva carga x recalque, este último fora obtido pela média das quatro leituras, em cada estágio de carga.

\subsubsection{Viga de reação}

A viga de reação utilizada nos ensaios tem elevada rigidez, com capacidade para suporte de carga de $2 \mathrm{MN}$, aplicada ao seu centro, sendo construída a partir de 4 
perfis I metálicos, de tal sorte que a alma resultante é vazada, a fim de transpassar-se tirantes, para o arrancamento das estacas. A Foto 4.2 mostra detalhes dessa viga.

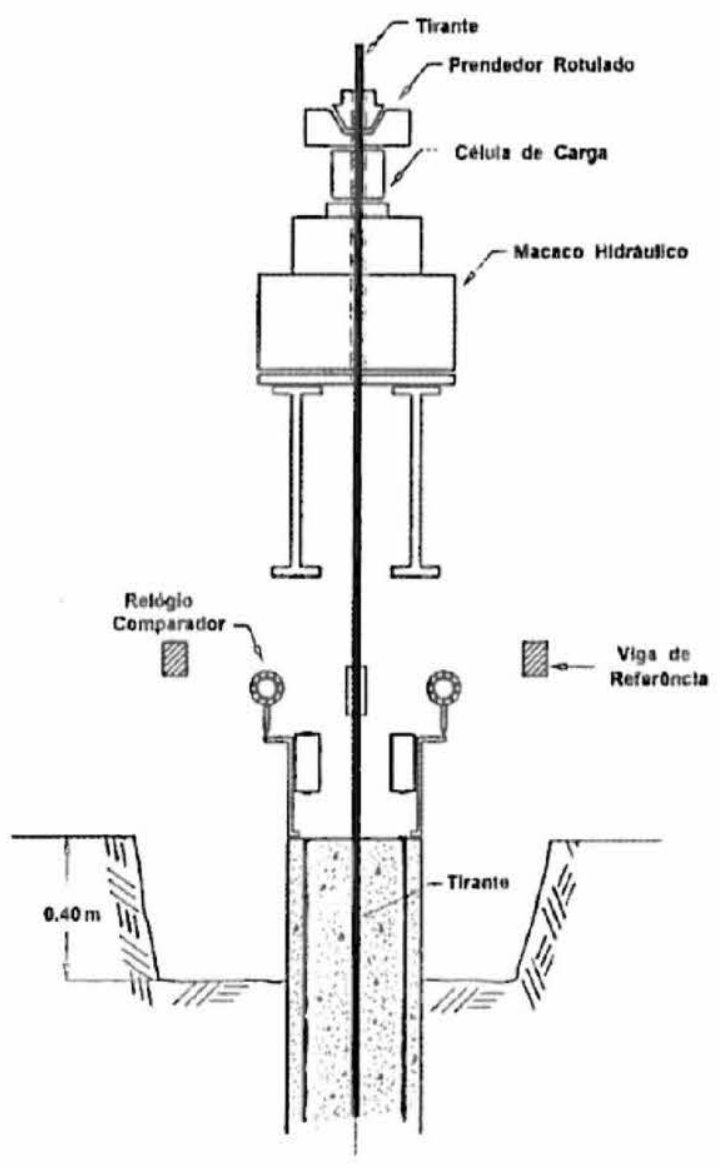

FIGURA 4.1 - Esquema de uma Prova de Carga à Tração em uma Estaca (Modificado de CARVALHO, 1991).

\subsection{Inundação do terreno}

Para realizar-se o ensaio com inundação do terreno, procedeu-se à abertura de uma cava, no topo da estaca, de dimensões aproximadas de $1,0 \times 1,0 \times 0,4 \mathrm{~m}$. Recarregava-se, a seguir, a estaca até a carga de trabalho, quando então começava-se a inundação, mantendo-a por um tempo de $48 \mathrm{~h}$; deste modo, caso não se comprovasse o colapso da ligação solo-estaca, ou seja, por uma deformação excessiva não estabilizada, procedia-se ao término do ensaio, continuando-se normalmente os acréscimos de carga até a ruptura daquela ligação. Ressalta-se que a carga de trabalho aqui considerada fora calculada a partir da carga máxima obtida na prova de carga, sem a utilização do critério de VAN DER VEEN (1953). 
A Foto 4.3 mostra em detalhes a cava, já inundada.

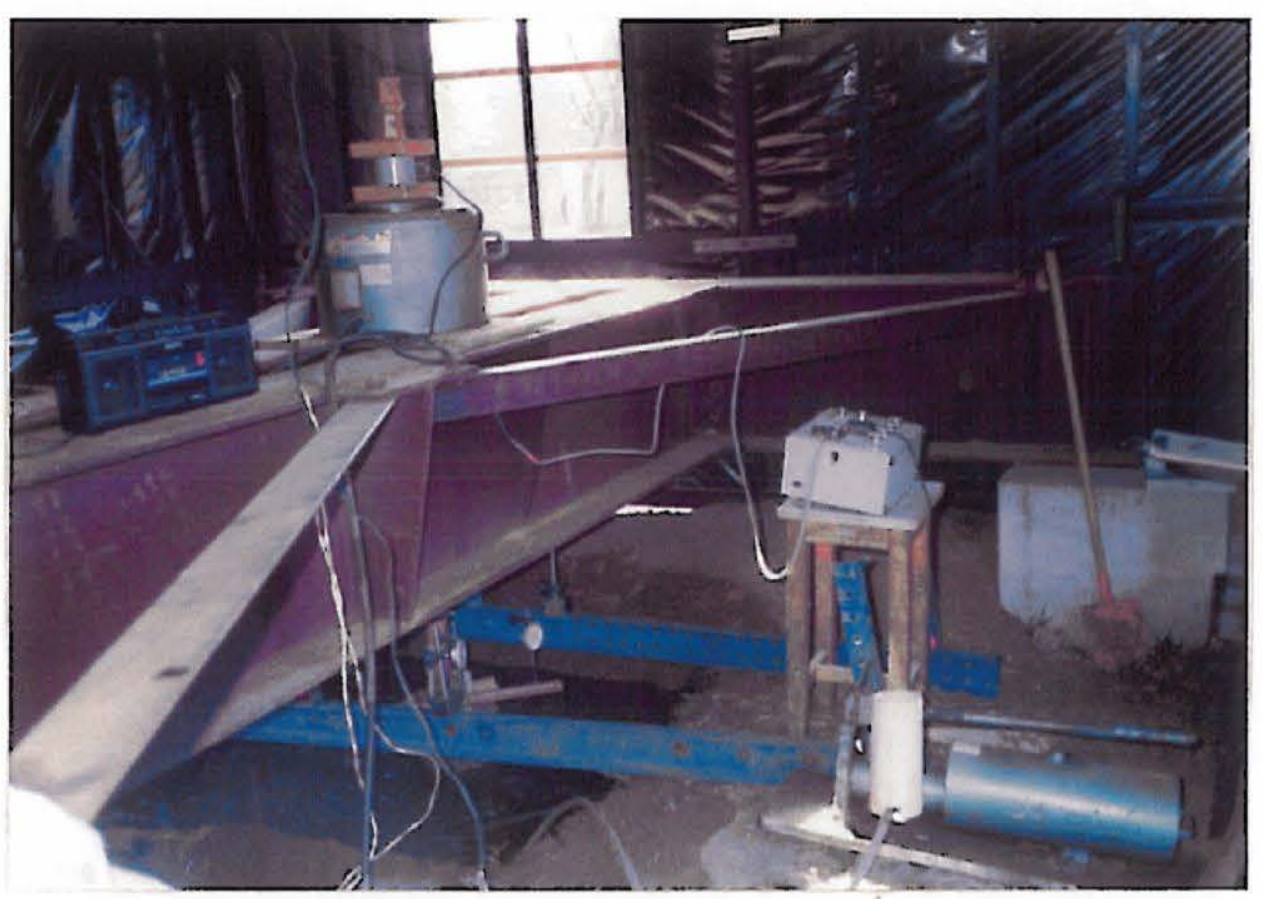

FOTO 4.1. - Equipamentos Utilizados nas Provas de Carga.

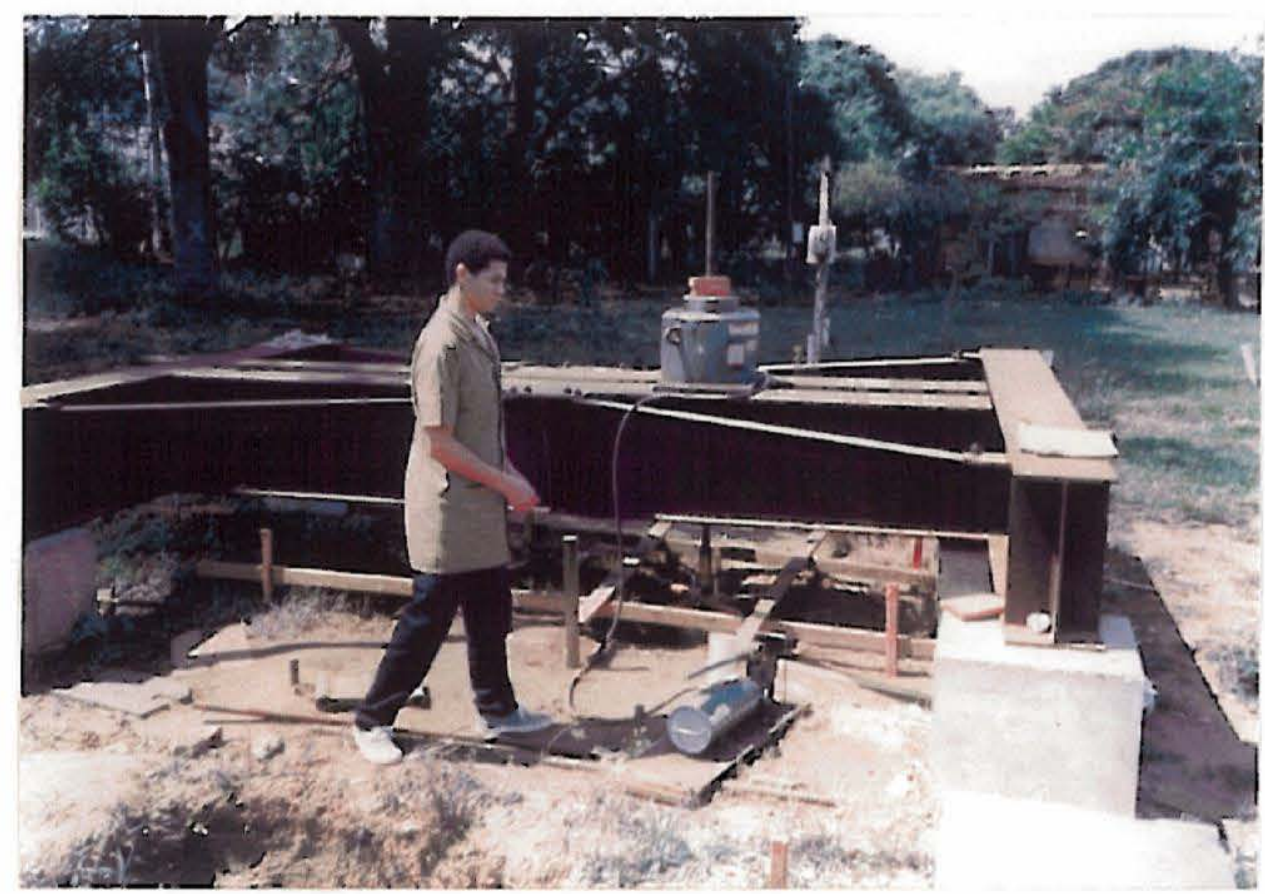

FOTO 4.2 - Vista da Viga de Reação. 


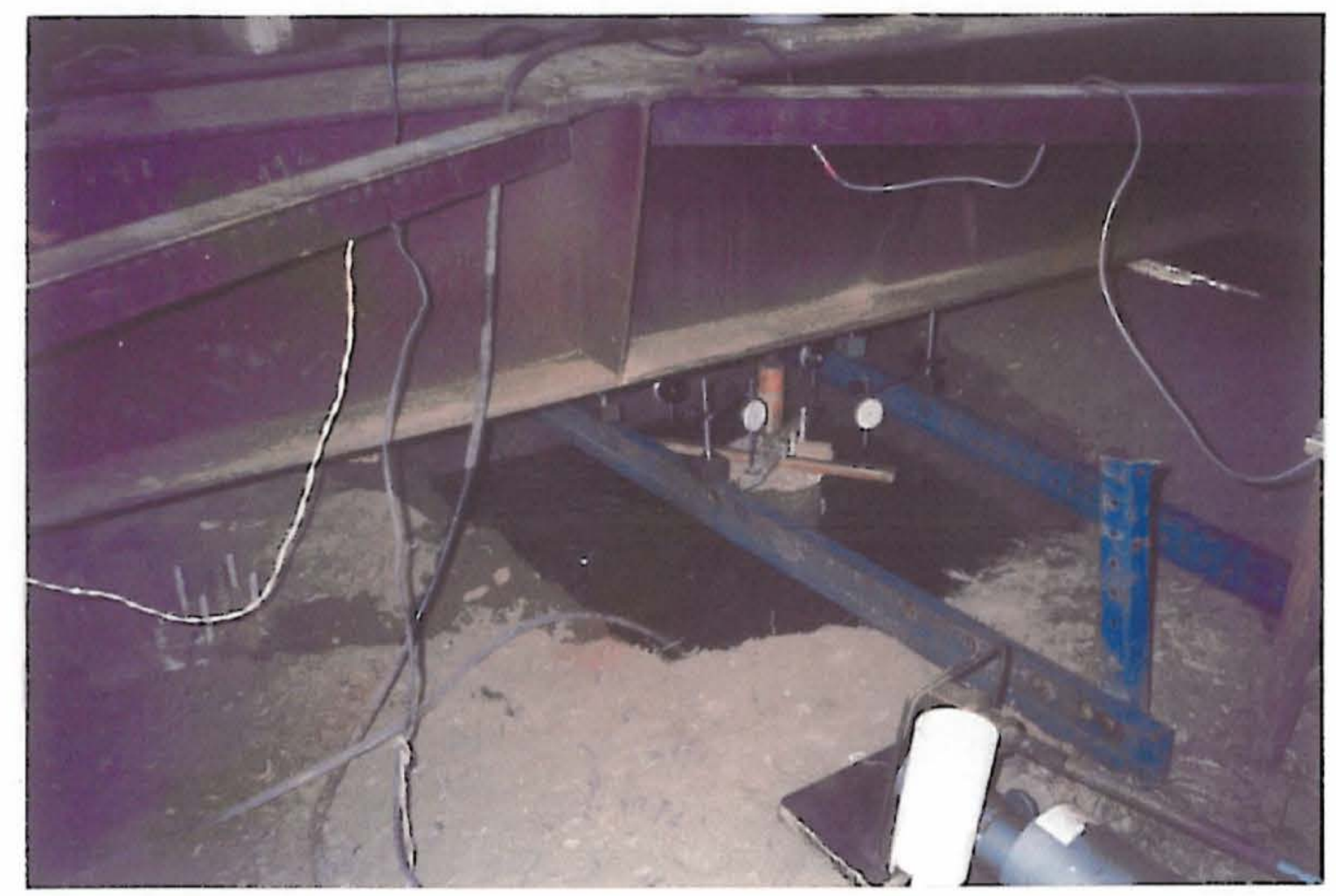

FOTO 4.3 - Cava em Torno do Topo da Estaca, Inundada por Água.

\subsection{Seqüência das Provas de Carga}

No total, foram realizadas 13 provas de carga nas 05 estacas ensaiadas. Em algumas das estacas, foi necessária a efetuação de várias provas de carga, a fim de dirimir-se eventuais dúvidas que surgiram, ao longo do prosseguimento das mesmas. Essas dúvidas relacionavam-se a diferenças elevadas nas cargas de ruptura encontradas, ou então, ao fato de uma estaca apresentar colapso da ligação estacasolo, embora em uma outra, idêntica e bem próxima, não tenha ocorrido esse fenômeno. Nos ítens 5.4.1 e 5.4.2, esses tópicos serão melhor detalhados.

A Tabela 4.1 apresenta a seqüência da realização das provas de carga, bem como as respectivas datas da ocorrência das mesmas. 
TABELA 4.1 - Seqüência de Realização das Provas de Carga nas Estacas Ensaiadas.

\begin{tabular}{|c|c|c|c|c|c|}
\hline \multirow{2}{*}{$\begin{array}{l}\text { Prova de } \\
\text { Carga No. }\end{array}$} & \multicolumn{2}{|c|}{ Estaca } & \multirow{2}{*}{$\begin{array}{l}\text { Estado } \\
\text { do Solo }\end{array}$} & \multirow{2}{*}{$\begin{array}{l}\text { Tipo de } \\
\text { Ensaio }\end{array}$} & \multirow[t]{2}{*}{ Data } \\
\hline & Número & Tipo & & & \\
\hline 01 & 01 & Apiloada & Natural & Rápido & $02 / 09 / 92$ \\
\hline 02 & 01 & Apiloada & Inundado & Rápido & $03 / 09 / 92$ \\
\hline 03 & 01 & Apiloada & Inundado & Rápido & $08 / 10 / 92$ \\
\hline 04 & 02 & Apiloada & Natural & Lento & $13 / 10 / 92$ \\
\hline 05 & 02 & Apiloada & Inundado & Lento & $16 / 10 / 92$ \\
\hline 06 & 03 & Escavada & Natural & Rápido & $04 / 11 / 92$ \\
\hline 07 & 03 & Escavada & Inundado & Rápido & $05 / 11 / 92$ \\
\hline 08 & 04 & Escavada & Natural & Lento & $30 / 03 / 93$ \\
\hline 09 & 04 & Escavada & Inundado & Lento & $31 / 03 / 93$ \\
\hline 10 & 01 & Apiloada & Inundado & Rápido & $26 / 07 / 93$ \\
\hline 11 & 05 & Strauss & Inundado & Rápido & $17 / 08 / 93$ \\
\hline 12 & 02 & Apiloada & Natural & Lento & $28 / 10 / 93$ \\
\hline 13 & 02 & Apiloada & Natural & Rápido & $29 / 10 / 93$ \\
\hline
\end{tabular}

Nos anexos C, D, E, F, G, H, I, J, K, L, M, N e O, são apresentadas as leituras das cargas e deslocamentos, para cada uma das provas de carga realizadas nas estacas ensaiadas. 


\section{Capítulo 5}

\section{APRESENTAÇÃO E ANÁLISE DOS RESULTADOS}

\subsection{Generalidades}

Neste capítulo, apresentam-se os parâmetros do solo e do conjunto estacasolo, adotados na previsão de carga última à tração das estacas, faz-se uma explanação geral sobre as curvas carga $\mathrm{x}$ deslocamento, obtidas das provas de carga, comparam-se as cargas últimas previstas pelos métodos $\mathrm{e}$ as cargas últimas obtidas nas provas de carga. Ademais, comparam-se os resultados encontrados por diversos pesquisadores, em fundações tracionadas, procurando relacionar alguns parâmetros entre si.

\subsection{Parâmetros Geotécnicos do Solo e do Conjunto Solo-Estaca}

A Tabela 5.1 mostra os valores médios dos parâmetros geotécnicos do solo, utilizados nos métodos de previsão, de acordo com as médias efetuadas às profundidades de 0 a $6 \mathrm{~m}$ (para estacas apiloadas e escavadas) e 0 a $9 \mathrm{~m}$ (estaca do tipo Strauss), a partir dos resultados de ensaios efetuados por MENEZES (1990).

A adesão solo-estaca $\left(c_{\mathfrak{a}}\right)$ e o ângulo de atrito solo-estaca $(\delta)$ foram estimados considerando a recomendação de POTYONDY (1961), iguais, respectivamente, a $80 \%$ da coesão drenada e $95 \%$ do ângulo de atrito interno efetivo do solo, para estacas escavadas de parede rugosa, em solo granular coesivo, de umidade média de $15 \%$, ao longo da profundidade de embutimento das estacas. A consideração de adotar-se os parâmetros de resistência efetiva do solo reside na sua elevada porosidade, que permite uma boa drenagem da água presente nos seus vazios.

A decisão de utilizar-se a estimativa de POTYONDY (1961) recaiu no fato de que muitos autores utilizaram as minorações da coesão e do ângulo de atrito interno do solo, utilizando-se os coeficientes apontados por esse autor.

Além disso, não obstante o trabalho de KULHAWY \& PATERSON (1979) ser mais recente, ele não aborda a adesão estaca-solo, o que não possibilitou a sua inclusão neste trabalho. 
TABELA 5.1 - Valores Médios dos Parâmetros do Subsolo Obtidos nos Ensaios Laboratoriais e Penetrométricos (MENEZES, 1990), com Respectivos Parâmetros do Conjunto Estaca-Solo.

\begin{tabular}{|c|c|c|c|c|c|}
\hline Estaca & $\gamma(\mathrm{kN} / \mathrm{m} 3)$ & $\mathrm{c}(\mathrm{kPa})$ & $\mathrm{ca}(\mathrm{kPa})$ & $\phi\left(^{\circ}\right)$ & $\delta\left(^{\circ}\right)$ \\
\hline Apiloada & 16,4 & 9,3 & 7,4 & 29,2 & 27,7 \\
\hline Escavada & 16,4 & 9,3 & 7,4 & 29,2 & 27,7 \\
\hline Strauss & 17,5 & 9,7 & 7,8 & 28,0 & 26,6 \\
\hline
\end{tabular}

\subsection{Cargas Máximas Obtidas nas Provas de Carga e Respectivos Ajustes}

A Tabela 5.2 apresenta os tipos e as caracteristicas geométricas das estacas ensaiadas, com as respectivas cargas máximas $\left(\mathrm{P}_{\text {máx. }}\right)$ obtidas nas provas de carga, bem como as cargas últimas à tração $(\mathrm{Pu})$, encontradas pelo critério de VAN DER VEEN (1953).

TABELA 5.2 - Tipos, Características Geométricas e Cargas de Rupturas das Estacas.

\begin{tabular}{|c|c|c|c|c|c|}
\hline Estaca & Tipo & $\mathrm{D}(\mathrm{m})$ & $\mathrm{L}(\mathrm{m})$ & $\mathrm{P}_{\operatorname{máx}}(\mathrm{kN})$ & $\mathrm{P}_{\boldsymbol{\mu}}(\mathrm{kN})$ \\
\hline 01 & Apiloada & 0,20 & 6,0 & 98 & 105 \\
\hline 02 & Apiloada & 0,20 & 6,0 & 70 & 80 \\
\hline 03 & Escavada & 0,25 & 6,0 & 105 & 109 \\
\hline 04 & Escavada & 0,25 & 6,0 & 142 & 152 \\
\hline 05 & Strauss & 0,32 & 9,0 & 390 & 410 \\
\hline
\end{tabular}

\subsection{Curvas Carga $x$ Deslocamento}

\subsubsection{Cargas máximas obtidas}

A Figura 5.1 apresenta a curva carga $\mathrm{x}$ recalque das estacas apiloadas (01 e 02), escavadas (03 e 04) e Strauss (05), nas quais mostram-se as cargas máximas obtidas nas provas de carga. Observa-se que, apesar das estacas idênticas encontrarem-se bem próximas umas das outras, houve uma diferença apreciável nas cargas máximas.

Poder-se-ia tentar explicar essa diferença através de dois argumentos. O primeiro seria que, apesar da pouca distância entre as estacas idênticas, pode haver uma diferenciação no perfil do solo, resultando em terreno com maior espessura de aterro e, daí, resistências diferentes. $\mathrm{O}$ segundo seria que o solo pode ter sofrido maior compactação, na fase de abertura do furo, pois, com efeito, um maior apiloamento pode densificar com mais eficácia o solo ao longo do fuste da estaca, 
como é a opinião de GRIGORYAN \& CHINENKOV (1980), ARUTYNOV et al. (1983) e LOBO (1991), entre outros. Daí a necessidade de reensaiar a estaca 02, a fim de verificar-se se realmente houve algum ensaio mal conduzido nela, ou então se confirmasse a discrepância entre estacas idênticas tão próximas. Tal diagnóstico é realizado nos ítens 5.4.3 e 5.4.4.
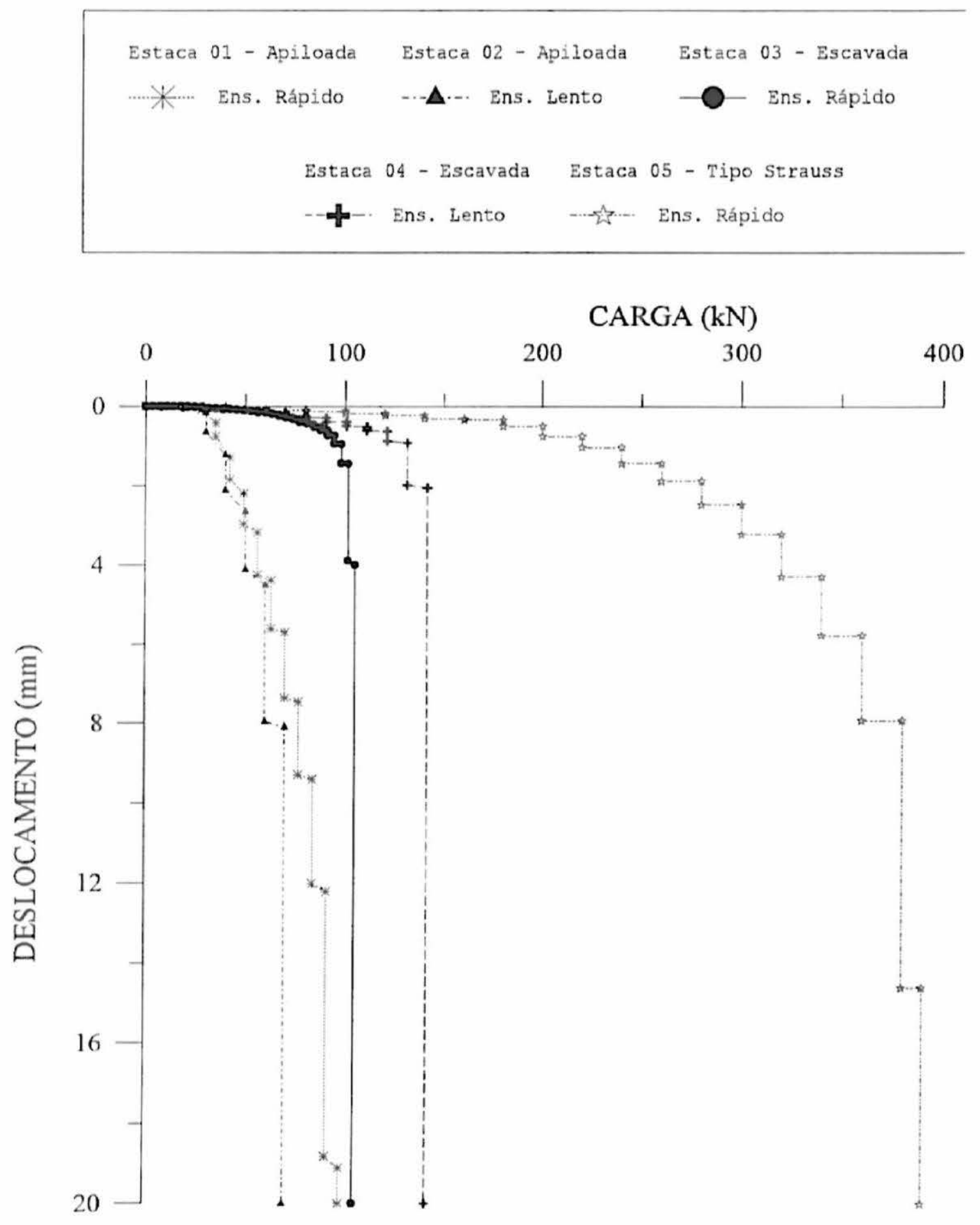

FIGURA 5. 1 - Curvas Carga x Deslocamento das Estacas 01, 02, 03, 04 e 05. 


\subsubsection{Influência da inundação do solo na carga última}

As Figuras 5.2 a 5.6 reproduzem o efeito da inundação do solo no comportamento das estacas 01, 02, 03, 04 e 05. Observa-se que as estacas 02, 03 e 04 apresentaram colapso, na carga de trabalho; todavia, nas estacas 01 e 05 , tal fenômeno não se verificou, senão com o prosseguimento da prova de carga.

$\mathrm{Na}$ estaca 01, o primeiro ensaio de inundação consistiu em acrescentar estágios sucessivos de carga, a cada $1,5 \mathrm{~h}$, após a carga de trabalho. $\mathrm{O}$ fato da estaca 01 não ter apresentado colapso da ligação solo-estaca, não obstante a estaca 02 , idêntica, ter apresentado, levou a reensaiá-la, posteriormente. No segundo e terceiro ensaios com solo inundado (terceiro e quarto, no total) por $48 \mathrm{~h}$, na carga de trabalho, novamente não ocorreu o colapso.

Poder-se-ia inquirir o porquê da não colapsibilidade das estacas 01 , no período de $48 \mathrm{~h}$ de inundação, como verificado nas demais. Uma tentativa de entender o fenômeno seria a adoção das idéias dos autores mencionados no ítem anterior, relacionando a redução ou eliminação da colapsibilidade com a eficiência de um bom apiloamento do solo, ao longo do fuste da estaca.

Quanto à estaca 05, ela atravessa a camada colapsível $(6 \mathrm{~m})$ e assenta-se no solo residual, do Grupo Bauru, que talvez não seja colapsível. Assim, uma maior carga seria necessária para que ocorresse o colapso da ligação solo-estaca, pois a pressão necessária para início do colapso aumenta no mesmo sentido da profundidade (ZARETSKII \& KARABAEV, 1987).

Na Tabela 5.3 são apresentados os tempos de inundação, necessários para início do processo de colapso, das estacas 02,03 e 04 . Na Tabela 5.4 são mostradas as reduções da carga última das estacas 01 e 05 , pelo efeito da inundação.

TABELA 5.3 - Intervalo de Tempo para Início do Colapso

\begin{tabular}{|c|c|}
\hline Estaca & $\Delta \mathrm{t}(\mathrm{h})$ \\
\hline 02 & 42,0 \\
\hline 03 & 13,5 \\
\hline 04 & 28,5 \\
\hline
\end{tabular}



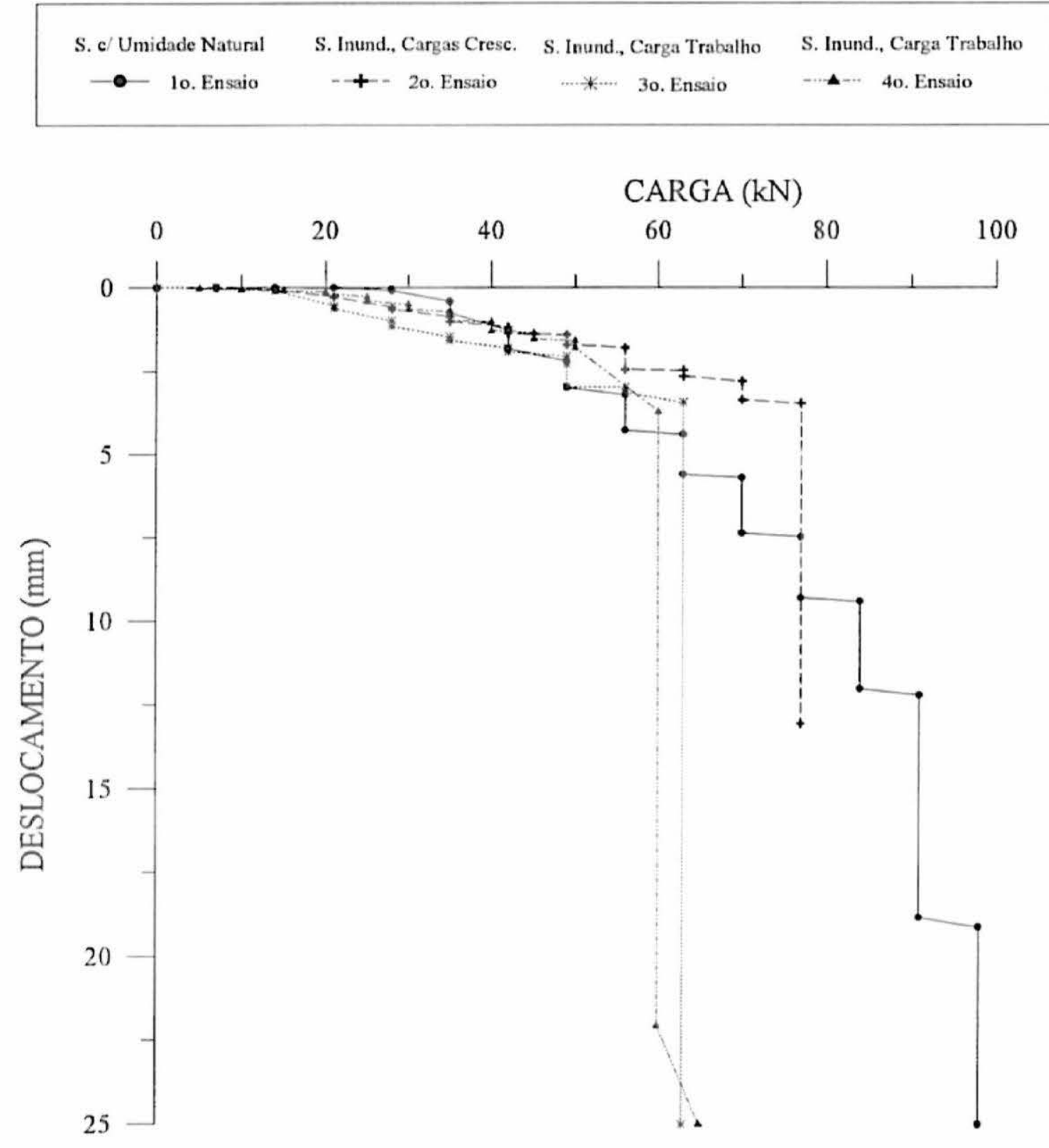

FIGURA 5.2. Curvas Carga $x$ Deslocamento da Estaca 01, com o Solo no Estado Natural e Inundado Sucessivamente.

TABELA 5.4 - Redução da Carga Última Devida a Inundação

\begin{tabular}{|c|c|c|c|}
\hline Estaca & $\begin{array}{c}\text { Carga Última } \\
(\mathrm{kN})\end{array}$ & $\begin{array}{c}\text { Carga de } \\
\text { Colapso }(\mathrm{kN})\end{array}$ & $\begin{array}{c}\text { Redução } \\
\eta(\%)\end{array}$ \\
\hline 01 & 105 & 63 & 40 \\
\hline 05 & 410 & 320 & 22 \\
\hline
\end{tabular}




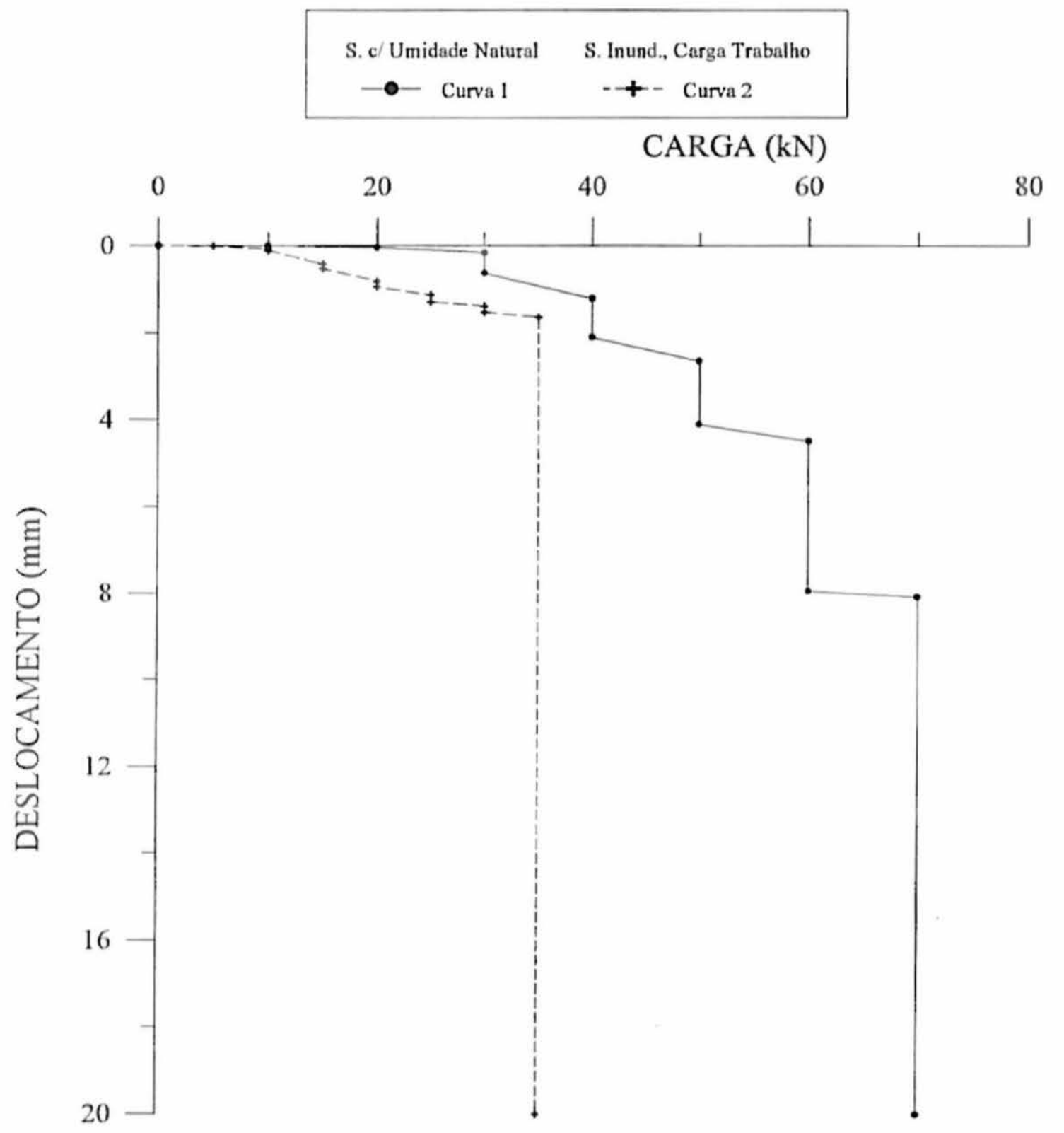

FIGURA 5.3 - Curvas Carga x Deslocamento da Estaca 2, com o Solo em Estado Natural e Inundado. 


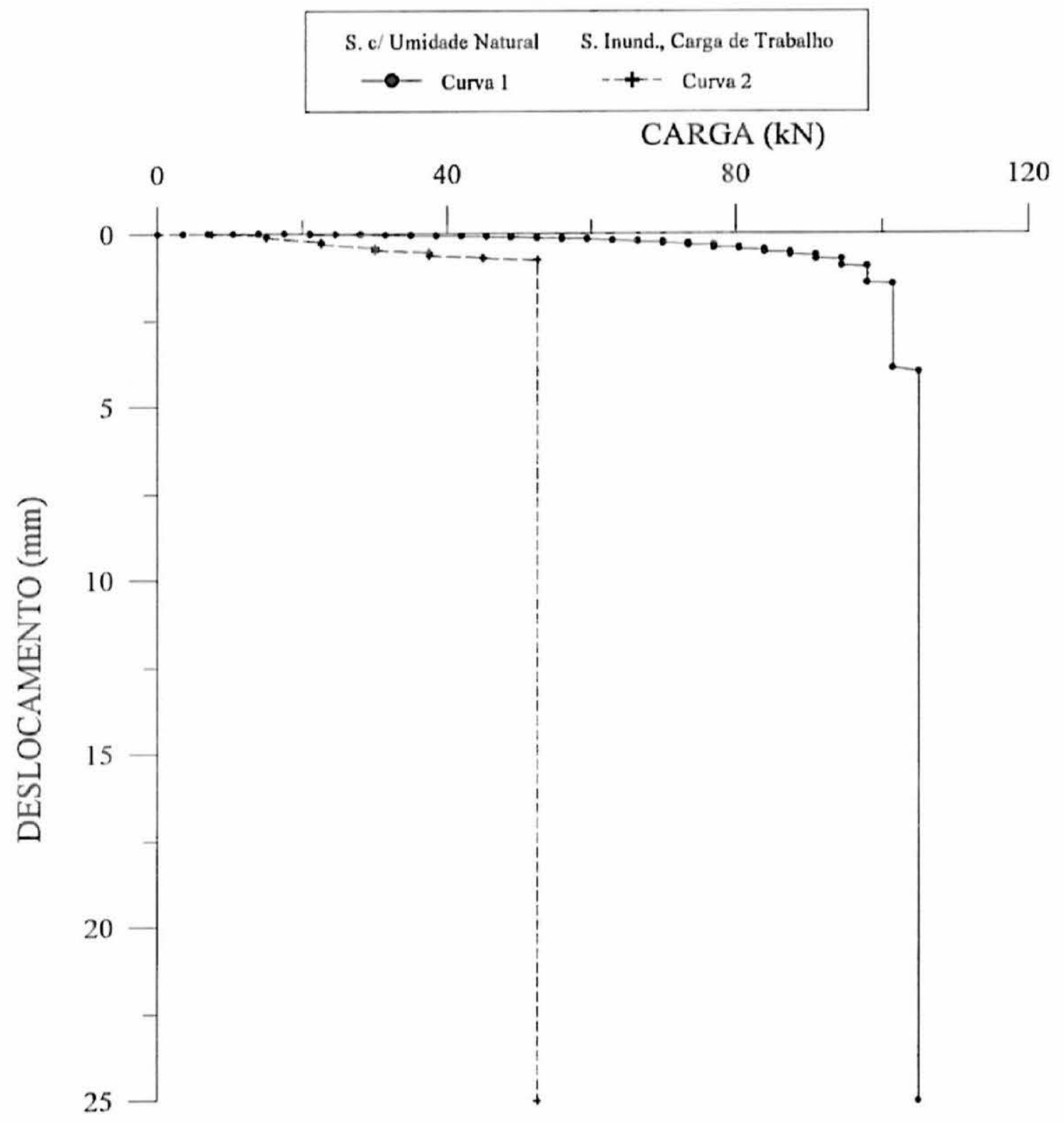

FIGURA 5.4 - Curvas Carga x Deslocamento da Estaca 03, com o Solo em Estado Natural e Inundado. 


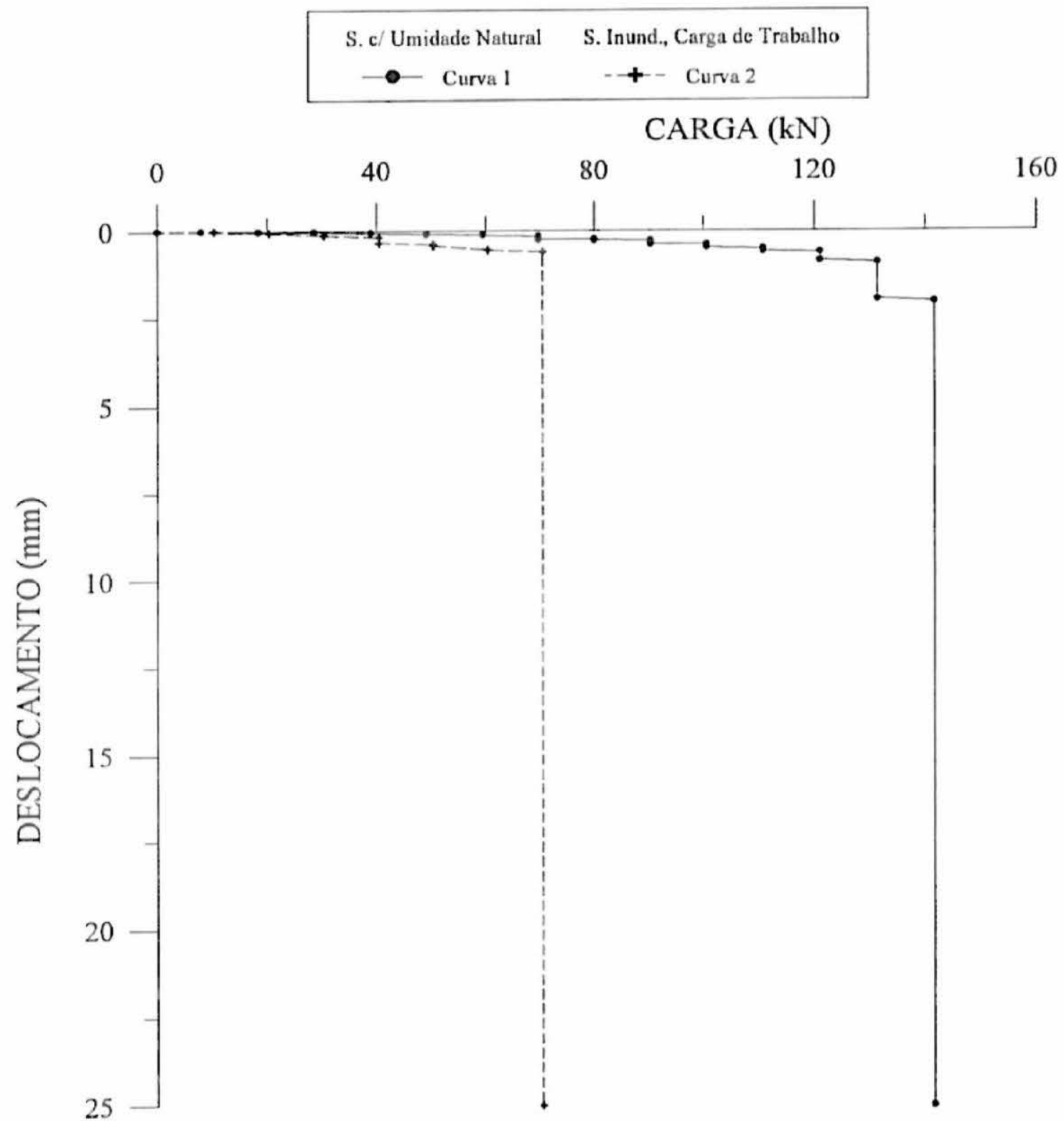

FIGURA 5.5 - Curvas Carga x Deslocamento da Estaca 04, com o Solo em Estado Natural e Inundado. 


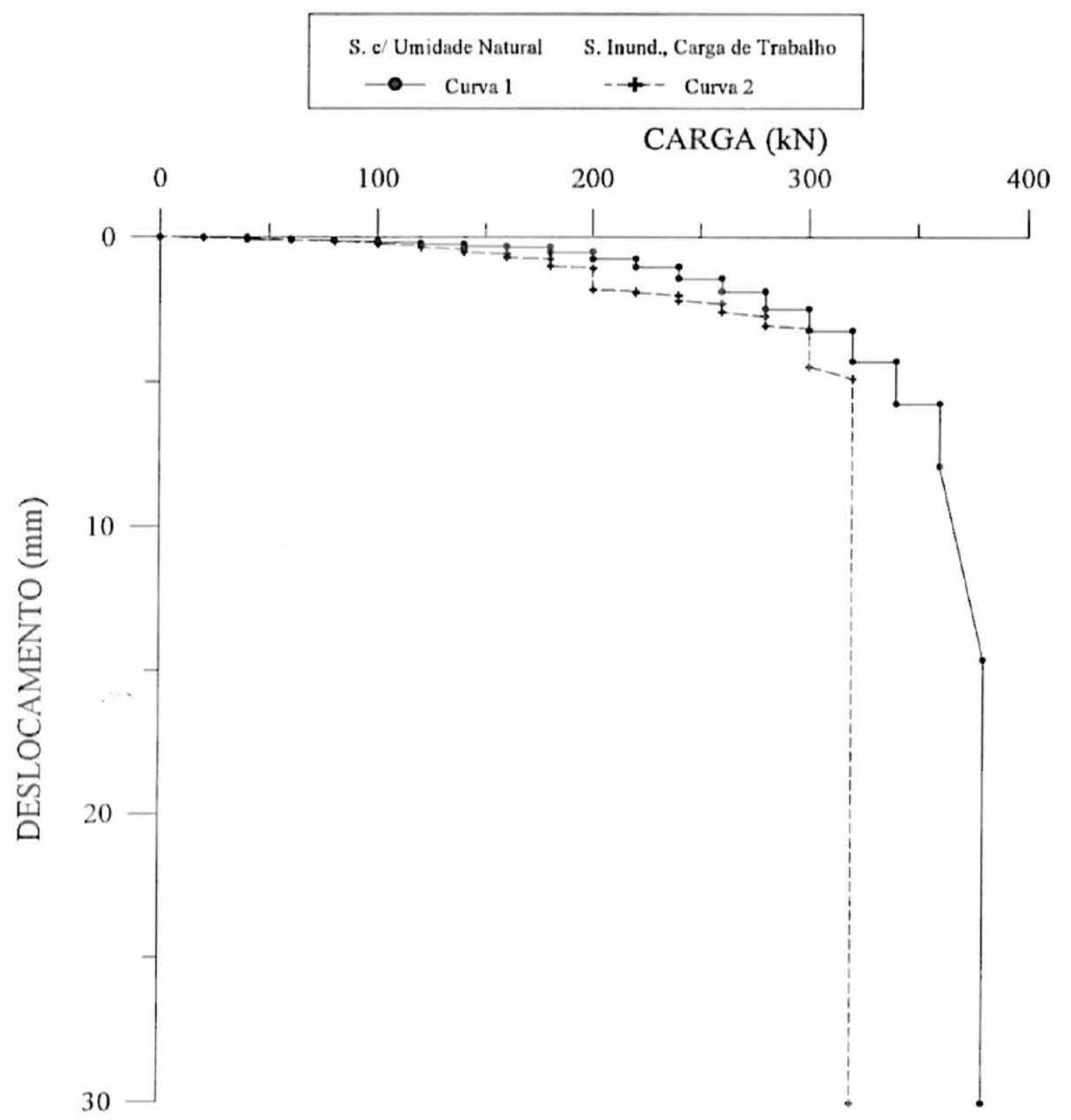

FIGURA 5.6 - Curvas Carga x Deslocamento da Estaca 05, com o Solo no Estado Natural e Inundado. 


\subsubsection{Efeito da velocidade de carregamento nas cargas últimas}

A Figura 5.7 mostra os gráficos carga $x$ deslocamento da estaca 02 , para os vários retestes efetuados, individualmente. Já a Figura 5.8 apresenta os mesmos ensaios, embora em uma forma de deslocamentos acumulados. Nota-se que o ensaio de carregamento rápido produziu uma carga de ruptura maior que o lento, como era de se esperar, conforme relatado por DANZIGER (1983) e MILITITSKY (1991). Analogamente ao comentado pelos autores, o ensaio rápido também conduziu a deslocamentos menores, para o mesmo nivel de carregamento.

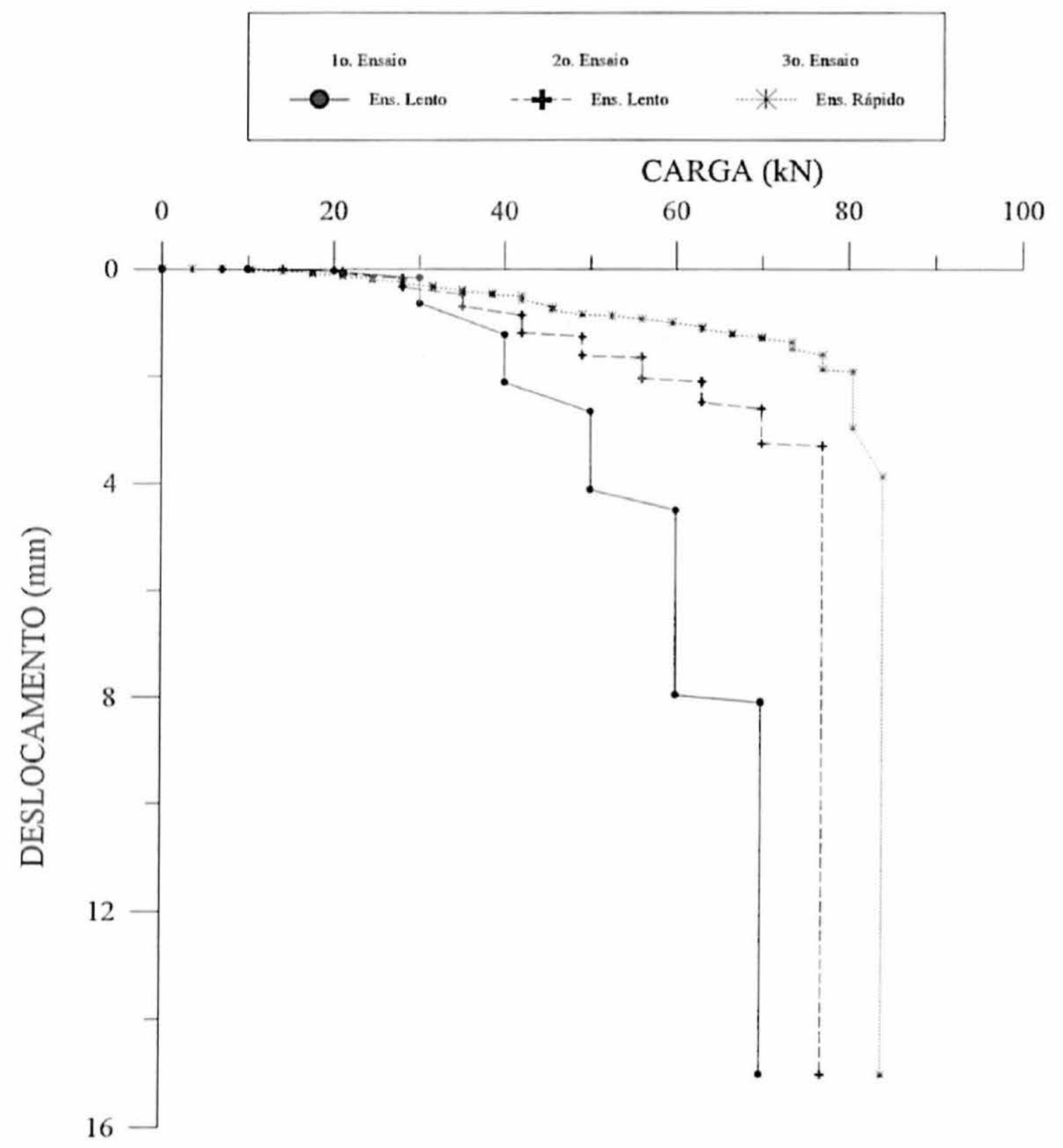

FIGURA 5.7 - Curvas Carga x Deslocamento da Estaca 02, para Sucessivos

Carregamentos, com o Solo na Umidade Natural. 


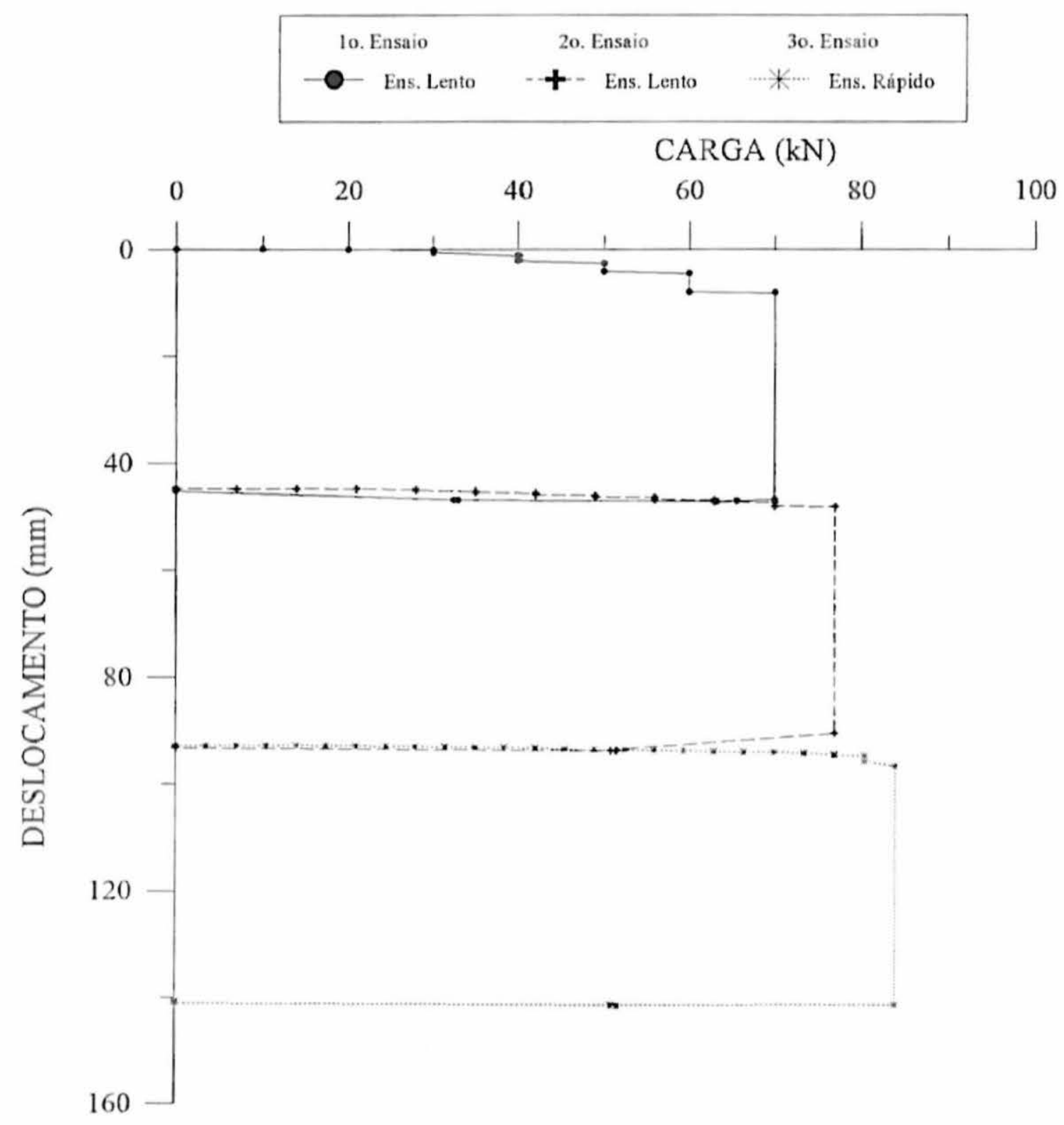

FIGURA 5.8 - Curvas Carga x Deslocamento da Estaca 02, para Sucessivos Carregamentos e Deslocamentos Acumulados, com o Solo na Umidade Natural.

\subsubsection{Efeito de carregamentos sucessivos}

Pelas Figuras 5.7 e 5.8, observa-se que a carga de ruptura aumenta com a realização dos recarregamentos sucessivos, embora DANZIGER (1983) tenha verificado que o reensaio à tração em uma sapata conduziu a uma carga de ruptura ligeiramente inferior à observada no primeiro teste. 


\subsubsection{Efeito do apiloamento do solo}

Observa-se, na Figura 5.1, comparando-se as estacas apiloadas e escavadas, que o apiloamento do solo não foi suficiente para produzir estacas com maior capacidade de carga que as estacas escavadas.

Duas razões talvez expliquem tal fato. A primeira é que, considerando-se comprimentos iguais, o diâmetro da estaca exerce forte influência na carga de ruptura. A segunda é que o apiloamento favorece a criação de um bulbo, na região da ponta da estaca, e, estando comprimida, a tendência é da parcela de resistência de ponta ser mais intensamente mobilizada (LOBO, 1991). Por outro lado, ao proceder-se ao arrancamento da estaca, conta-se apenas com a mobilização do atrito lateral, parecendo crer que o apiloamento só teria validade comparando-se estacas com mesmo diâmetro.

Quanto ao efeito da inundação, ainda que a estaca 02 apresentasse colapso de sua ligação com o solo, há que considerar-se que a estaca 01 , apesar de três inundações do solo ao seu redor, não apresentou colapso. Isto parece confirmar as observações de GRIGORYAN \& CHINENKOV (1980), ARUTYUNOV et al. (1983), e LOBO (1991), entre muitos outros, para o caso de estacas comprimidas.

\subsubsection{Deslocamentos na carga de trabalho e de ruptura}

$\mathrm{Na}$ Tabela 5.5 pode ser visto que os deslocamentos médios verificados na carga de trabalho, conforme o tipo da estaca, são bastante reduzidos, como observado por DANZIGER (1983), ORLANDO (1985), RAO \& VENKATESH (1985), MATOS (1989), CARVALHO (1991), LEHANE et al. (1993), e De NICOLA \& RANDOLPH (1993), ente outros.

Para esses autores, a carga lateral última é totalmente mobilizada para pequenas porcentagens do diâmetro da estaca.

TABELA 5.5 - Deslocamentos médios para 50\% e 90\% da Carga Última.

\begin{tabular}{|c|c|c|c|c|}
\hline & \multicolumn{2}{|c|}{$\rho_{50}$} & \multicolumn{2}{c|}{$\rho_{00}$} \\
\hline Estaca & $\mathrm{mm}$ & $\% \mathrm{D}$ & $\mathrm{mm}$ & $\% \mathrm{D}$ \\
\hline Apiloada & 5,4 & 2,7 & 41 & 20,5 \\
\hline Escavada & 0,1 & 0,04 & 31,1 & 12,5 \\
\hline Strauss & 0,8 & 0,25 & 24,9 & 7,8 \\
\hline
\end{tabular}

\subsubsection{Atrito lateral médio}

A Tabela 5. 6 apresenta os valores de atrito lateral total médio, $\mathrm{f}_{\mathrm{S}}$ (carga última dividida pela área lateral das estacas). Pode-se notar que, aparentemente, o 
atrito lateral médio não guarda relação com $\mathrm{L} / \mathrm{D}$, mas sim com o diâmetro da fundação, pois, aumentando-se este, há um acréscimo de $\mathrm{f}_{\mathrm{S}}$. Deve-se atentar que o elevado atrito lateral verificado na estaca Strauss, corresponde, principalmente, à parcela de embutimento na camada residual. CARVALHO \& ALBUQUERQUE (1994) concluiram que, descontando-se a parcela de atrito mobilizada no solo residual, em estacas escavadas de $10 \mathrm{~m}$ de comprimento, os valores de atrito lateral na camada colapsível situavam-se em torno de $30 \mathrm{kPa}$.

TABELA 5.6 - Atrito Lateral Total Médio.

\begin{tabular}{|c|c|c|}
\hline Estaca & L/D & $\mathrm{f}_{\mathrm{S}}(\mathrm{kPa})$ \\
\hline Apiloada & 30 & 24,2 \\
\hline Escavada & 24 & 27,7 \\
\hline Strauss & 28 & 45,3 \\
\hline
\end{tabular}

\subsection{Comparação entre as Cargas Últimas Estimadas e as Obtidas nas Provas de Carga}

A seguir, faz-se um comentário genérico sobre a aplicação dos diversos métodos de previsão de carga última, utilizados neste trabalho:

a) Método do Tronco de Cone: Adotou-se o ângulo da superficie de ruptura com a vertical $(\alpha)$ com os valores de $6^{\circ}, 10^{\circ}(\phi / 3)$ e $15^{\circ}(\phi / 2)$; o primeiro valor é o encontrado por CARVALHO (1991) para estacas escavadas, de relação L/D próximas às estacas em estudo, e no mesmo local; os dois últimos dizem respeito à faixa de valores geralmente recomendados por autores, quando não se dispõe de resultados de provas de carga;

b) Teoria da Resistência Lateral: Considerou-se a superficie de ruptura ocorrendo na interação solo-estaca, aplicando-se a equação citada por POULOS \& DAVIS (1980), para valores de coeficientes de empuxo em repouso $\left(\mathrm{K}_{\mathrm{O}}=1\right.$-sen $\phi$ ', JÁKY, 1948), como recomendado por vários autores, para solos normalmente adensados (MEYERHOF, 1976; HANNA \& GHALY, 1992, entre outros) e o encontrado por extrapolação, a partir de valores determinados por CARVALHO (1991), para estacas de relação L/D semelhantes e no mesmo local; 
c) Método de MEYERHOF \& ADAMS (1968): Consideraram-se as fundações como profundas, adotando-se os parâmetros de resistência efetiva do solo;

d) Método de MEYERHOF (1973): Aqui há um melhor tratamento teórico para estacas e tubulões. Considerou-se a adesão $\left(c_{a}\right)$ e o ângulo de atrito estaca -

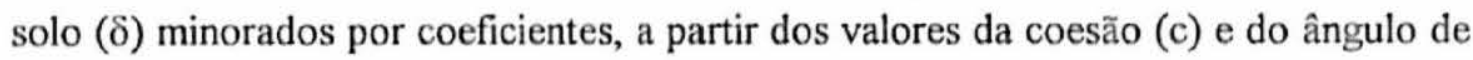
atrito interno do solo $(\phi)$, conforme sugestão de POTYONDY (1961).

e) Método de DAS (1983): Determinou-se a carga última sem a adesão, conforme prescrição original, para estacas em areias, e com adesão, considerando a parcela devido a coesão do solo em estudo, conforme fizera CARVALHO (1991);

f) Método de Grenoble: Utilizou-se o ângulo da superficie de ruptura com a vertical $(\lambda)$ para os valores de $(-\phi / 8)$, conforme recomendação do método original e 0, de acordo com sugestão posterior de vários autores (DANZIGER, 1983; ORLANDO, 1985; MATOS, 1989; CARVALHO, 1991).

A Tabela 5.7 apresenta os valores médios de carga de ruptura obtidos nas provas de carga, em função do tipo específico das estacas (exceto a do tipo Straus). A Tabela 5.8 mostra as cargas últimas previstas pelos diferentes métodos, com as diversas hipóteses consideradas nos cálculos das mesmas, em função do tipo de estaca.

A Figura 5.8-A apresenta a dispersão da carga última prevista, em relação à verificada, nas provas de carga. Nota-se a boa aproximação conseguida pelos métodos que consideram a ruptura ocorrendo pela interface estaca-solo.

TABELA 5.7 - Valor Médio da Carga Máxima e da Carga Última.

\begin{tabular}{|c|c|c|c|c|}
\hline Estaca & $\mathrm{D}(\mathrm{m})$ & $\mathrm{L}(\mathrm{m})$ & $\mathrm{P}_{\text {máx }}(\mathrm{kN})$ & $\mathrm{P}_{\boldsymbol{U}}(\mathrm{kN})$ \\
\hline Apiloada & 0,20 & 6,0 & 84 & 92,5 \\
\hline Escavada & 0,25 & 6,0 & 123,5 & 130,5 \\
\hline Strauss & 0,32 & 9,0 & 390 & 410 \\
\hline
\end{tabular}


M. \& ADAMS (68) TRONCO DE CONE MEYERHOF (73a)

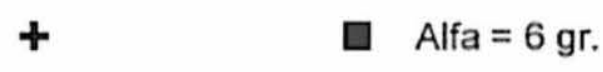

TEORIA RES. LAT. DAS (83) GRENOBLE

$\mathrm{O} K=\mathrm{Ko} \diamond$ (Com Adesão) \& Rupt. pela Interf.

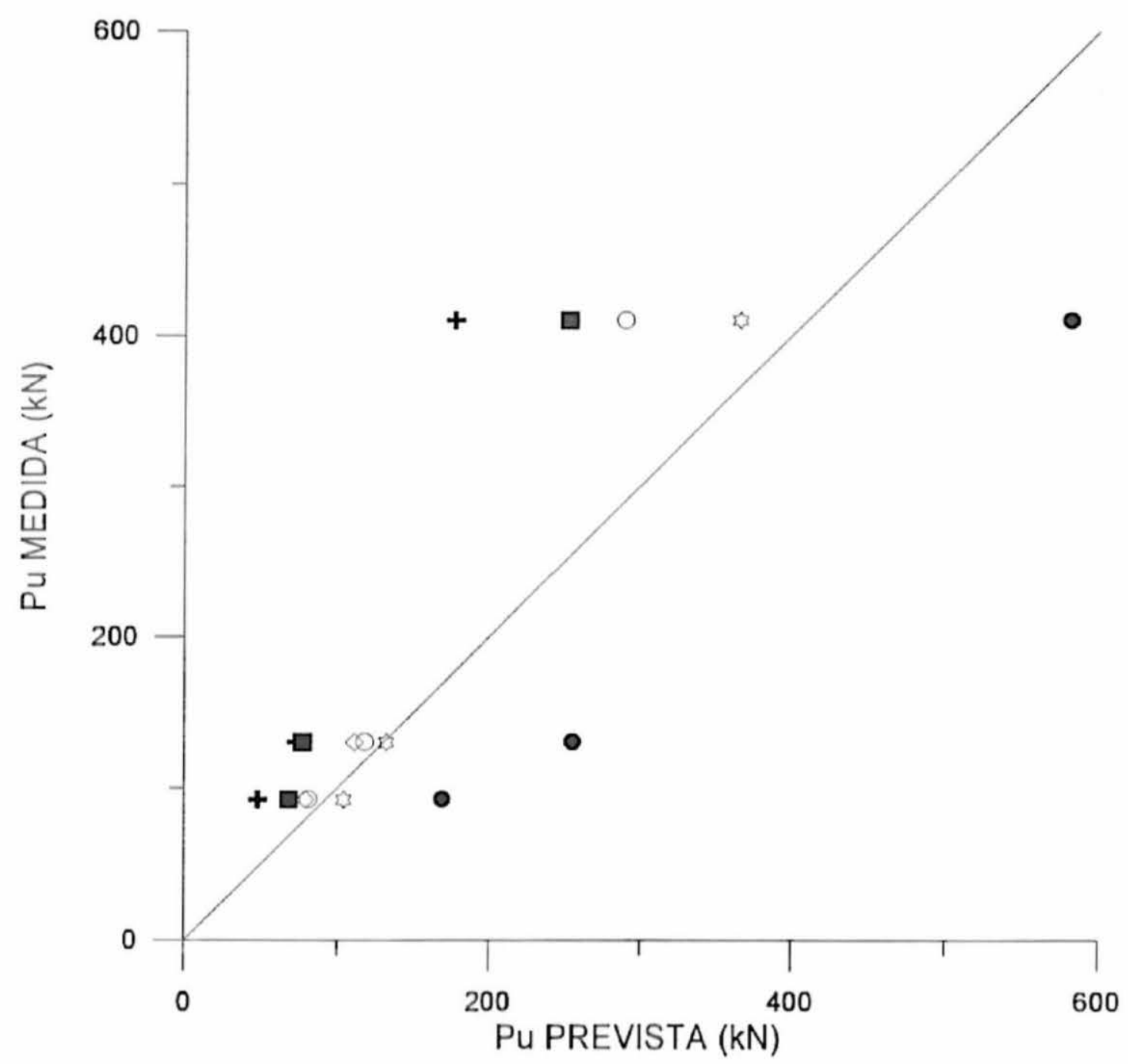

FIGURA 5.8 -A - Carga Última Prevista x Carga Última Medida, pelos Diversos Métodos. 
TABELA 5.8 - Cargas Últimas à Tração Previstas $\left(\mathrm{P}_{\mathrm{u} \text { prev, }}, \mathrm{kN}\right)$ e Erros Relativos (\%) na Adoção dos Diversos Métodos.

\begin{tabular}{|c|c|c|c|c|c|}
\hline Estaca & $\begin{array}{c}\text { Meyerhof \& } \\
\text { Adams }\end{array}$ & \multicolumn{3}{|c|}{ Tronco de Cone } & Meyerhof \\
\hline-- & -- & $\alpha=6^{\circ}$ & $\alpha=10^{\circ}$ & $\alpha=15^{\circ}$ & -- \\
\hline Apiloada & 48 & 68 & 156 & 324 & 169 \\
& $(+48)$ & $(+26)$ & $(-69)$ & $(-250)$ & $(-83)$ \\
\hline Escavada & 73 & 77 & 168 & 340 & 255 \\
& $(+44)$ & $(+41)$ & $(-29)$ & $(-161)$ & $(-95)$ \\
\hline Strauss & 177 & 252 & 571 & 1180 & 582 \\
& $(+57)$ & $(+39)$ & $(-39)$ & $(-188)$ & $(-42)$ \\
\hline Obs: \\
Erro Relativo (\%) $=((\mathrm{Pu}-$ Puprev. $/ \mathrm{Pu}) \times 100$ \\
\hline
\end{tabular}

TABELA 5.8 (Cont.). Carga Última à Tração Prevista $\left(\mathrm{P}_{\mathrm{u} \text { prev. }}, \mathrm{kN}\right)$ e Erro $(\%)$ em Relação à Prova de Carga.

\begin{tabular}{|c|c|c|c|c|c|c|}
\hline & \multicolumn{2}{|c|}{ Teoria da Res. Lateral } & \multicolumn{2}{|c|}{ Das } & \multicolumn{2}{c|}{ Grenoble } \\
\hline Estaca & $\mathrm{K}=\mathrm{K}_{\Omega}$ & $\mathrm{K}=0,68$ & $\left(\mathrm{c}_{\mathrm{a}}=0\right)$ & $\left(\mathrm{c}_{\mathrm{a}}\right)$ & $\lambda=(-\phi / 8)$ & $\lambda=0$ \\
\hline Apiloada & 81 & 99 & 50 & 79 & 263 & 104 \\
& $\begin{array}{c}812) \\
(+12)\end{array}$ & $(+46)$ & $(+15)$ & $(-184)$ & $(-12)$ \\
\hline Escavada & 118 & 146 & 76 & 111 & 292 & 132 \\
& $(+10)$ & $(-12)$ & $(+42)$ & $(+15)$ & $(-124)$ & $(-1)$ \\
\hline Strauss & 290 & 346 & 183 & 253 & 850 & 366 \\
& $(+29)$ & $(+16)$ & $(+55)$ & $(+38)$ & $(-107)$ & $(+11)$ \\
\hline
\end{tabular}

\subsubsection{Consideraçöes sobre o método do tronco de cone:}

Observa-se que com pouca variação no ângulo $\alpha$, há uma grande discrepância nas cargas últimas estimadas. Mesmo utilizando $\alpha=6^{\circ}$, conforme encontrado por CARVALHO (1991), para estacas com L/D semelhantes e no mesmo local do ensaio, os resultados mostraram-se conservadores, embora para 10 e $15^{\circ}$, os resultados sejam 
totalmente contra a segurança. Isto confirma a ressalva que diversos autores teceram a este método (DANZIGER, 1983; PALADINO, 1985; ORLANDO, 1989), devido sua enorme imprecisão e dispersão nos valores estimados de carga última.

Portanto, a utilização deste método na previsão de carga última de fundações tracionadas deve ser feita judiciosamente, uma vez que trata-se, talvez, do método mais utilizado no nosso país, no dimensionamento de fundações de torres de linhas de transmissão (PALADINO, 1972, 75; DANZIGER, 1983; ASHCAR, MEDEIROS e PALADINO, 1985). Foi feita uma retroanálise, para cada tipo de estaca, do valor do ângulo $\alpha$, apresentada no item 5.6.

\subsubsection{Considerações sobre o método de Meyerhof \& Adams:}

Este método apresentou resultados bastante conservadores, tal como encontrado por DANZIGER (1983), MATOS (1989) e CARVALHO (1991), talvez por tratar-se de um método desenvolvido essencialmente para placas. É possivel haver outra explicação, mas essa parece ser a mais plausivel, pois se um método desenvolvido essencialmente para estacas leva, algumas vezes, a reultados muito distantes do esperado, é coerente pensar-se que fundações em placas, rasas ou profundas, têm comportamento totalmente distinto de fundações em estacas ou tubulões.

\subsubsection{Considerações sobre o método de Meyerhof}

Apesar deste método ter sido desenvolvido para fundações em estacas, ele apresentou resultados contra a segurança, conforme verificado por vários autores (ORLANDO, 1985; MATOS, 1985 e CARVALHO, 1991).

Considerando-se válida a minoração dos parâmetros c e $\phi$, pela sugestão de POTYONDY (1961), a causa de valores tão superestimados recai no coeficiente $\mathbf{K}_{\mathbf{u}}$. É feita, no item 5.6, uma retroanálise desse coeficiente, a fim de verificar-se o seu valor aproximado. 


\subsubsection{Considerações sobre o método de Grenoble}

A consideração de adotar-se $\lambda=-\phi / 8$ conduziu a resultados superestimados das cargas últimas previstas.

Todavia, a assimilação da ruptura ocorrendo na interface estaca-solo $(\lambda=0)$ conduz a resultados mais realistas, com boa aproximação entre as cargas previstas e as medidas, nas provas de carga. DANZIGER (1983), ORLANDO (1985), MATOS (1989) e CARVALHO (1991) chegaram às mesmas conclusões.

De todos os métodos, foi o que apresentou resultados mais satisfatórios, confirmando o seu elevado embasamento teórico.

\subsubsection{Considerações sobre o método de Das}

A aplicação desse método, no seu desenvolvimento original, ou seja, sem a parcela devida a adesão, levou a resultados subestimados. Ao acrescentar-se a parcela devida a coesão, os resultados tornam-se mais próximos das cargas de ruptura medidas. É possivel que a inclusão da parcela de adesão, à formulação original, feita por CARVALHO (1991), careça de rigor excessivamente teórico. Contudo, desde que os resultados apresentaram-se razoavelmente próximos aos medidos nas provas de carga, e, por sua vez, mesmo os métodos com bom desenvolvimento teórico conduzem a resultados não tão perfeitamente desejados, parece válida essa inclusão da adesão, em solos genéricos, granulares coesivos.

\subsubsection{Consideraçỏes sobre o método da teoria da resistência lateral}

Ao adotar-se o coeficiente de empuxo igual ao de reposo, $\mathrm{K}_{\mathrm{O}}=1-\operatorname{sen} \phi^{\prime}$ (JÁKY, 1948), os resultados mostraram-se um pouco conservadores, embora razoavelmente próximos dos medidos. Quanto ao valor de $\mathrm{K}_{\mathrm{h}}=0,68$, os resultados variaram de conservadores (estacas apiloadas e escavadas) a superestimado (estaca Strauss). No ítem 5.6.1 é realizada uma retroanálise, fornecendo o valor provável do coeficiente de empuxo. 


\subsection{Retroanálises}

Neste item, procura-se determinar os valores prováveis dos parâmetros envolvidos na previsão de carga última de estacas tracionadas. A Tabela 5.9 apresenta esses parâmetros, em relação ao método de previsão considerado.

TABELA 5.9 - Retroanálise dos Parâmetros Utilizados nas Equações de Previsão de Cargas Últimas à Tração.

\begin{tabular}{|c|c|c|c|c|}
\hline $\begin{array}{c}\text { Comprimento } \\
\text { da Estaca }\end{array}$ & Carga Última & $\begin{array}{c}\text { Tronco de } \\
\text { Cone }\end{array}$ & Meyerhof & Das \\
\hline $\mathrm{L}(\mathrm{m})$ & $\mathrm{P}_{\mathrm{U}}(\mathrm{kN})$ & $\alpha\left(^{\circ}\right)$ & $\mathrm{K}_{\mathrm{U}}$ & $\mathrm{K}_{\mathrm{U}}$ \\
\hline 6,0 & 92,5 & 7,5 & 0,61 & 1,31 \\
\hline 6,0 & 130,5 & 8,5 & 0,58 & 1,28 \\
\hline 9,0 & 410,0 & 8,0 & 0,85 & 1,72 \\
\hline
\end{tabular}

\subsubsection{Coeficiente de Empuxo $\left(K_{h}\right)$.}

A equação do método de Meyerhof e o da teoria da resistência lateral são semelhantes, diferenciando-se na adoção do coeficiente de empuxo a adotar-se. Em vista disso, o coeficiente $\mathrm{K}_{\mathrm{h}}$ determinado na retroanálise serve tanto para especificar o coeficiente de arrancamento $\mathrm{K}_{\mathrm{u}}$, da equação de Meyerhof, quanto o coeficiente de empuxo, da teoria da resistência lateral.

A Tabela 5.10 mostra várias fórmulas para a estimativa de $\mathrm{K}_{\mathrm{h}}$, de acordo com a recomendação de vários autores, utilizando-se os parâmetros geotécnicos do solo em estudo. Comparando esses coeficientes com valor de $\mathrm{K}_{\mathrm{h}}$, determinado na retroanálise, nota-se que há uma melhor aproximação com o coeficiente de empuxo em repouso, sugerido por JÁKY (1948), para solos normalmente adensados, ainda que, com o apiloamento do solo, esperar-se-ia um coeficiente próximo ao passivo, para as estacas apiloadas e Strauss. MATOS (1989) encontrou boa aproximação no método de resistência lateral adotando o coeficiente ativo, para estacas brocas de $2 \mathrm{e}$ $3 \mathrm{~m}$ de comprimento, embora mencionasse que melhores resultados seriam obtidos utilizando-se um coeficiente igual à metade de $\mathrm{K}_{\mathrm{a}}$. Contudo, MATOS (1989) relatou 
que um coeficiente de empuxo máximo igual a 0,7 , conforme sugestão do Código Japonês de Estruturas Portuárias, de 1971, mostra-se adequado à previsão da carga última. Notou-se que, aumentando a relação $\mathrm{L} / \mathrm{D}, \mathrm{K}_{\mathrm{h}}$ também aumentou, para as estacas apiloadas e escavadas, analogamente ao verificado por CARVALHO (1991), mas ao contrário do observado por RAO \& VENKATESH (1985).

Quanto ao coeficiente $\mathrm{K}_{\mathrm{u}}$, utilizado na equação de Das, parece situar-se próximo ao sugerido por SOWA (1970), qual seja, o de admiti-lo igual à relação entre o peso específico do concreto, pelo do solo, devido a pressão que o concreto recém-lançado exerce contra o solo circundante à estaca.

TABELA 5.10 - Valores de $\mathrm{K}_{\mathrm{h}}$ Recomendados por Diversos Autores.

\begin{tabular}{|c|c|c|}
\hline \multicolumn{3}{|c|}{ Estacas Escavadas e Apiloadas } \\
\hline Autor & Formulação & Valor de $\mathrm{K}_{\mathrm{h}}$ \\
\hline JÁKY (1948) & $\mathrm{Ko}=1-\operatorname{sen} \phi^{\prime}$ & 0,51 \\
\hline SAGLAMER (1975) & $\mathrm{K}_{\Omega}(\mathrm{NC})=0,97\left[1-0,97\left(\operatorname{sen} \phi^{\prime}\right)\right]$ & 0,51 \\
\hline RANKINE & $K_{\mathrm{a}}=\operatorname{tg}^{2}\left(45-\phi^{\prime} / 2\right)$ & 0,34 \\
\hline RANKINE & $\mathrm{K}_{\mathrm{p}}=1 / \mathrm{K}_{\mathrm{a}}$ & 2,90 \\
\hline SOWA (1970) & $\mathrm{K}_{\mathrm{C}}=\gamma_{\mathrm{c}} / \gamma$ & 1,52 \\
\hline \multicolumn{3}{|c|}{ Estaca Strauss } \\
\hline Autor & Formulação & Valor de $\mathrm{K}_{\mathrm{h}}$ \\
\hline JÁKY (1948) & $\mathrm{K}_{\Omega}=1-\operatorname{sen} \phi^{\prime}$ & 0,53 \\
\hline SAGLAMER (1975) & $\mathrm{Ko}_{(N C)}=0,97\left[1-0,97\left(\operatorname{sen} \phi^{\prime}\right)\right]$ & 0,53 \\
\hline RANKINE & $\mathrm{K}_{\mathrm{a}}=\operatorname{tg}^{2}\left(45-\phi^{\prime} / 2\right)$ & 0,36 \\
\hline RANKINE & $\mathrm{K}_{\mathrm{p}}=1 / \mathrm{K}_{\mathrm{a}}$ & 2,77 \\
\hline SOWA (1970) & $\mathrm{K}_{\mathrm{C}}=\gamma_{\mathrm{c}} / \gamma$ & 1,42 \\
\hline
\end{tabular}

\subsection{2. Ângulo da superficie de ruptura do método do tronco de cone}

Notou-se que o ângulo $\alpha$ decresce com o aumento de L/D, como observado por ORLANDO (1985).

Isto ratifica o fato de que, no mesmo tipo de solo, apenas variando o comprimento ou diâmetro da estaca, pode haver mudança do ângulo $\alpha$, o que torna o 
emprego do método do tronco de cone ainda mais imprevisivel, quando da estimativa da carga última de fundações tracionadas.

\subsection{Comparação dos Resultados Obtidos}

\subsubsection{Generalidades}

Com o fito de tentar obter-se alguma possível relação entre os parâmetros do solo e do conjunto estaca-solo, são apresentadas algumas comparações entre os resultados obtidos neste trabalho, com os de alguns autores que estudaram a capacidade de carga de fundações tracionadas. A Tabela 5.11 apresenta as fundações ensaiadas, embutidas em vários tipos de solos, com os respectivos locais dos experimentos. A Tabela 5.12 mostra os parâmetros geotécnicos obtidos por diversos autores, e que constam na bibliografia nacional. Alguns parâmetros foram calculados, quando possível, por retroanálise, a partir das informações relatadas pelos autores.

\subsection{2 Ângulo da superfície de ruptura do método do tronco de cone $(\alpha)$}

A Figura 5.9 apresenta alguns resultados do ângulo $\alpha$, em função do coeficiente de embutimento L/D. Pode ser visto que, aumentando-se o valor de L/D, o ângulo $\alpha$ diminui, conforme já anteriormente mencionado. A Figura 5.10 mostra a regressão efetuada nos pontos dispersos. A equação que apresentou melhor coeficiente de determinação $\left(R^{2}\right)$ foi do tipo $\log (y)=B^{*} \log (x)+A$, onde y é o ângulo $\alpha, \mathrm{x}$ é o coeficiente L/D e B e A são os coeficientes da equação. A regressão obtida é:

$$
\log (y)=-0,603 \cdot \log (x)+3,984
$$

$\operatorname{com} \mathrm{R}^{2}=0,66$

Em termos de potenciação, tem-se:

$$
=\left(\frac{L}{D}\right)^{-0,603} .53,71
$$

Pode-se indagar se tal aproximação é válida, uma vez que ela conta com estacas de vários tipos (apiloada, escavada e do tipo Strauss) e também com tubulão sem base alargada, embutidos em solos de comportamento distintos.

$\mathrm{Na}$ verdade, se for levado em conta que o método do tronco de cone não dispõe de nenhum tratamento teórico que considere distintos tipos de solo, e conseqüentemente, distintos parâmetros geotécnicos do solo, talvez não haja tanta discrepância na consideração de o ângulo $\alpha$ variar com $L / D$, conforme a equação acima. 
Observa-se também que há uma faixa limite de variação superior e uma outra, inferior, praticamente paralelas à curva de regressão ajustada. Portanto, pode-se adotar, por segurança, a faixa limite inferior, determinando-se, então, valores conservadores do ângulo $\alpha$.

TABELA 5.11 - Fundações Ensaiadas à Tração por Diversos Autores.

\begin{tabular}{|c|c|c|c|c|c|c|}
\hline Autor & Local & Solo & Fundação & $\mathrm{L}(\mathrm{m})$ & $\mathrm{D}(\mathrm{m})$ & $\mathrm{L} / \mathrm{D}$ \\
\hline \multirow{2}{*}{$\begin{array}{c}\text { Danziger } \\
\text { (1983) }\end{array}$} & \multirow{2}{*}{$\begin{array}{l}\text { Adrianó- } \\
\text { polis (RJ) }\end{array}$} & \multirow{2}{*}{$\begin{array}{c}\text { Areia Silto } \\
\text { Argilosa }\end{array}$} & Tubulão & 7,0 & 0,80 & 8,8 \\
\hline & & & Tubulão & 4,0 & 0,70 & 5,7 \\
\hline \multirow{3}{*}{$\begin{array}{l}\text { Orlando } \\
\text { (1985) }\end{array}$} & \multirow{3}{*}{$\begin{array}{c}\text { Bauru } \\
\text { (SP) }\end{array}$} & \multirow{3}{*}{$\begin{array}{c}\text { Areia } \\
\text { Porosa } \\
\text { Argilosa }\end{array}$} & Tubulão & 6,0 & 0,50 & 12,0 \\
\hline & & & Tubulão & 6,0 & 1,20 & 5,0 \\
\hline & & & Tubulão & 8,0 & 0,75 & 10,7 \\
\hline \multirow{2}{*}{$\begin{array}{l}\text { Monteiro } \\
\text { (1985) }\end{array}$} & \multirow{2}{*}{$\begin{array}{l}\text { Ilha Solteira } \\
\text { (SP) }\end{array}$} & \multirow{2}{*}{$\begin{array}{c}\text { Areia Porosa } \\
\text { Argilosa }\end{array}$} & Est. Escav. & 3,5 & 0,25 & 14,0 \\
\hline & & & Est. Escav. & 5,0 & 0,30 & 16,7 \\
\hline \multirow{2}{*}{$\begin{array}{l}\text { Matos } \\
(1989)\end{array}$} & \multirow{2}{*}{$\begin{array}{l}\text { Cachoeiri- } \\
\text { nha (RS) }\end{array}$} & \multirow{2}{*}{$\begin{array}{c}\text { Argila Silto } \\
\text { Arenosa }\end{array}$} & Est. Escav. & 2,0 & 0,20 & 10,0 \\
\hline & & & Est. Escav. & 3,0 & 0,20 & 15,0 \\
\hline $\begin{array}{l}\text { C. \& S. } \\
(1990)\end{array}$ & Ilha Solt. (SP) & Are. Por. Arg. & Est. Escav. & 6,0 & 0,25 & 24,0 \\
\hline \multirow{3}{*}{$\begin{array}{l}\text { Carvalho } \\
\text { (1991) }\end{array}$} & \multirow{3}{*}{$\begin{array}{c}\text { São } \\
\text { Carlos } \\
\text { (SP) }\end{array}$} & \multirow{3}{*}{$\begin{array}{c}\text { Areia } \\
\text { Porosa } \\
\text { Argilosa }\end{array}$} & Est. Escav. & 10,0 & 0,35 & 28,6 \\
\hline & & & Est. Escav. & 10,0 & 0,40 & 25,0 \\
\hline & & & Est. Escav. & 10,0 & 0,50 & 20,0 \\
\hline $\begin{array}{c}\text { C. \& ALB. } \\
\text { (1994) }\end{array}$ & Ilha Solt. (SP) & Are. Por. Arg. & Est. Escav. & 6,0 & 0,25 & 24,0 \\
\hline \multirow{3}{*}{$\begin{array}{l}\text { Campelo } \\
\text { (1994) }\end{array}$} & \multirow{3}{*}{$\begin{array}{l}\text { São } \\
\text { Carlos } \\
\text { (SP) }\end{array}$} & \multirow{3}{*}{$\begin{array}{c}\text { Areia } \\
\text { Porosa } \\
\text { Argilosa }\end{array}$} & Est. Apiloada & 6,0 & 0,20 & 30,0 \\
\hline & & & Est. Escav. & 6,0 & 0,25 & 24,0 \\
\hline & & & Est. Strauss & 9,0 & 0,32 & 28,0 \\
\hline
\end{tabular}

\subsubsection{Atrito lateral médio à tração $\left(f_{S}\right)$}

Observando a Figura 5.11, nota-se que na região de São Carlos e alhures (Ilha Solteira e Bauru), que possuem solos porosos colapsiveis, muito semelhantes, o atrito lateral médio à tração é da ordem de $30 \mathrm{kPa}$. Nota-se também que o atrito lateral médio é muito sensível em relação ao solo local, variando desde $9 \mathrm{kPa}$ (MATOS, 1989) até 71 kPa (DANZIGER, 1983).

Subseqüentemente, é mostrado nas Figuras 5.12 e 5.13 o atrito lateral versus (L/D), com uma terceira variável: o diâmetro e o comprimento da fundação, respectivamente. Na Figura 5.14, é apresentado o atrito lateral versus o comprimento da fundação, em função de uma terceira variável: o diâmetro, a saber.

Observando-se as Figuras 5.12, 5.13 e 5.14, verifica-se que, devido a grande dispersão dos pontos, parece não haver uma relação aparente entre o atrito lateral com os parâmetros geométricos da fundação. 
TABELA 5.12 - Parâmetros Geotécnicos Obtidos por Diversos Autores

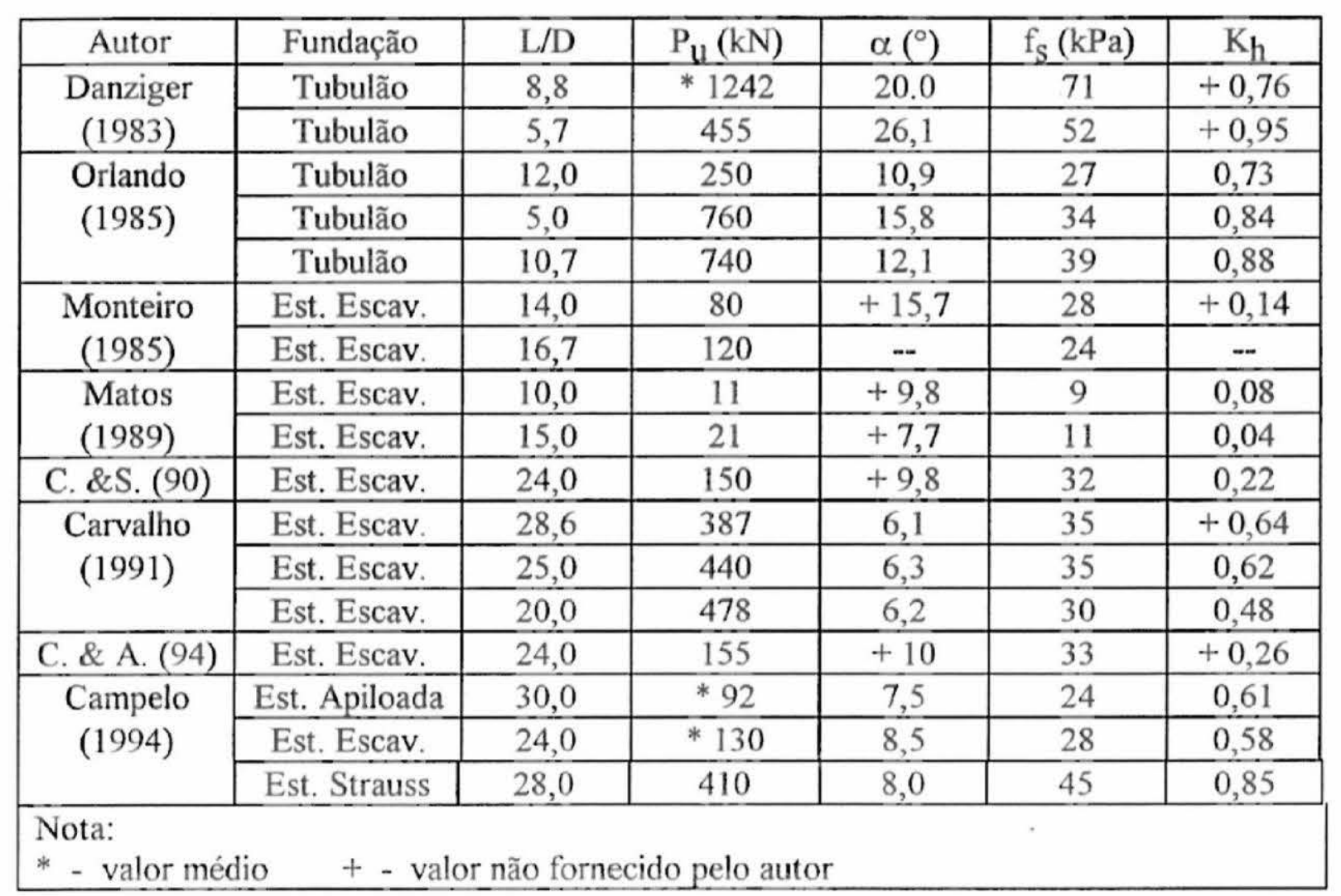

\subsubsection{Coeficiente de empuxo $\left(K_{h}\right)$}

A Figura 5.15 mostra que, para a região de São Carlos, o coeficiente de empuxo é da ordem de 0,60 , muito próximo ao coeficiente de empuxo em repouso, obtido pela equação de JÁKY (1948) e SAGLAMER (1975). Observa-se também que $\mathrm{K}_{\mathrm{h}}$ é influenciado simultaneamente pelo tipo de solo e da fundação.

As Figuras 5.16 e 5.17 mostram o coeficiente de empuxo, em função de (L/D) e de outras variáveis: o diâmetro e o comprimento da fundação, respectivamente. A Figura 5.18 apresenta o coeficiente de empuxo em função do comprimento, sendo o diâmetro a variável comum. Nota-se aqui também que a dispersão dos pontos assinalados não permitem determinar uma relação apropriada entre o coeficiente de empuxo e os parâmetros geométricos da fundação.

\subsubsection{Deslocamentos na carga de trabalho}

É visto na Figura 5.23 que os deslocamentos na carga de trabalho não ultrapassaram a $0,5 \%$ do diâmetro da fundação. Portanto, os deslocamentos parecem não ser uma preocupação relevante no dimensionamento de fundações em tubulões $\mathrm{e}$ estacas. 


\begin{tabular}{|c|c|c|}
\hline DANZIGER (83) & ORLANDO (85) & MATOS (89) \\
\hline Tubulão & Tubulão & Est. Escav. \\
\hline
\end{tabular}

\begin{tabular}{ccccc}
\hline CAMPELO (94) & CARVALHO (91) & C. \& SOUZA (90) \\
* Apil., Esc. e Strauss & $\square$ & Esc. & $\triangle$ & Esc. \\
\hline
\end{tabular}

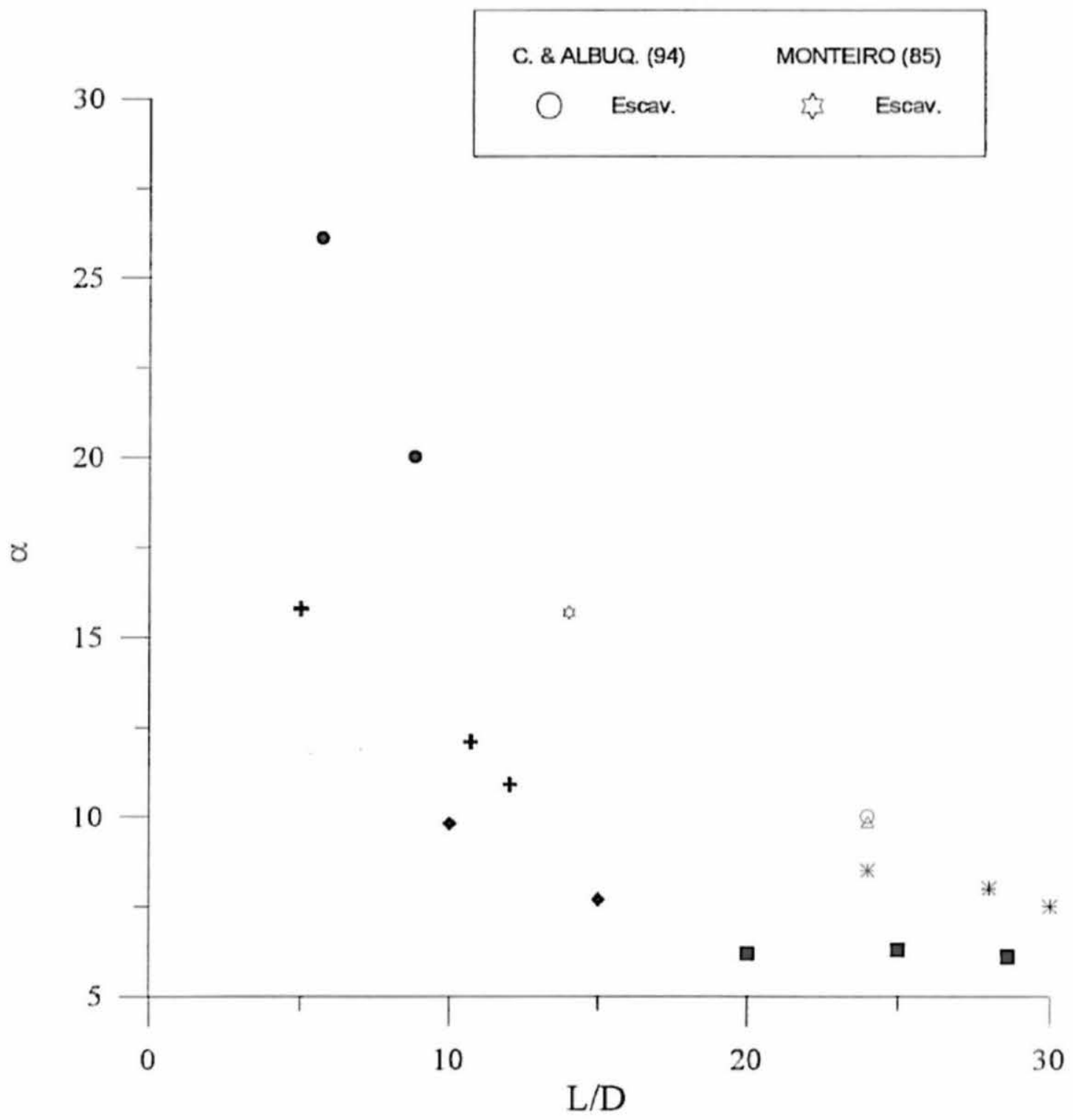

FIGURA 5.9 - Ângulo $\alpha$, em Função de L/D, para Diversos Tipos de Fundações. 


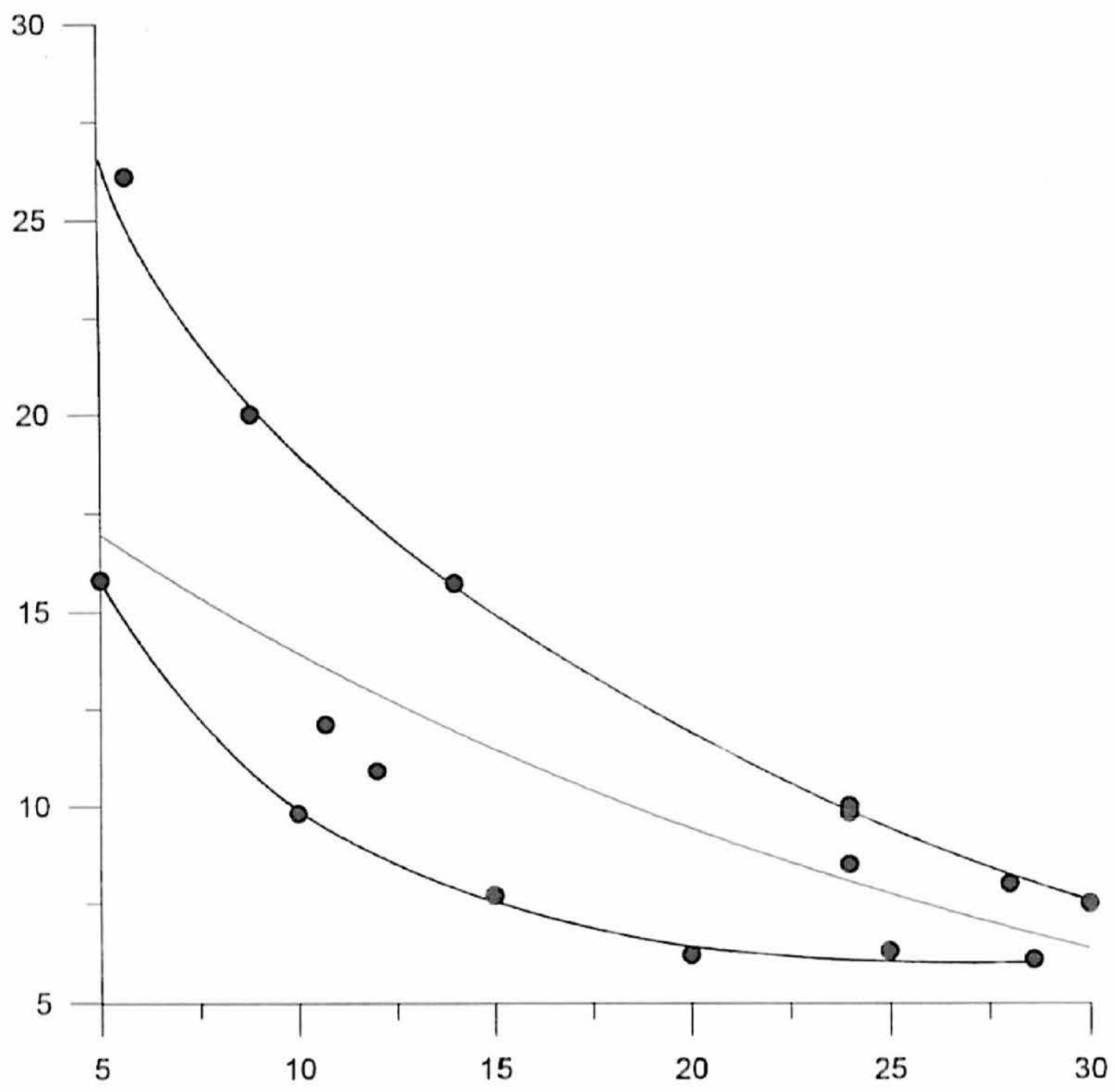

FIGURA 5.10 - Curva de Regressão Obtida para $\alpha$ em Função de L/D. 

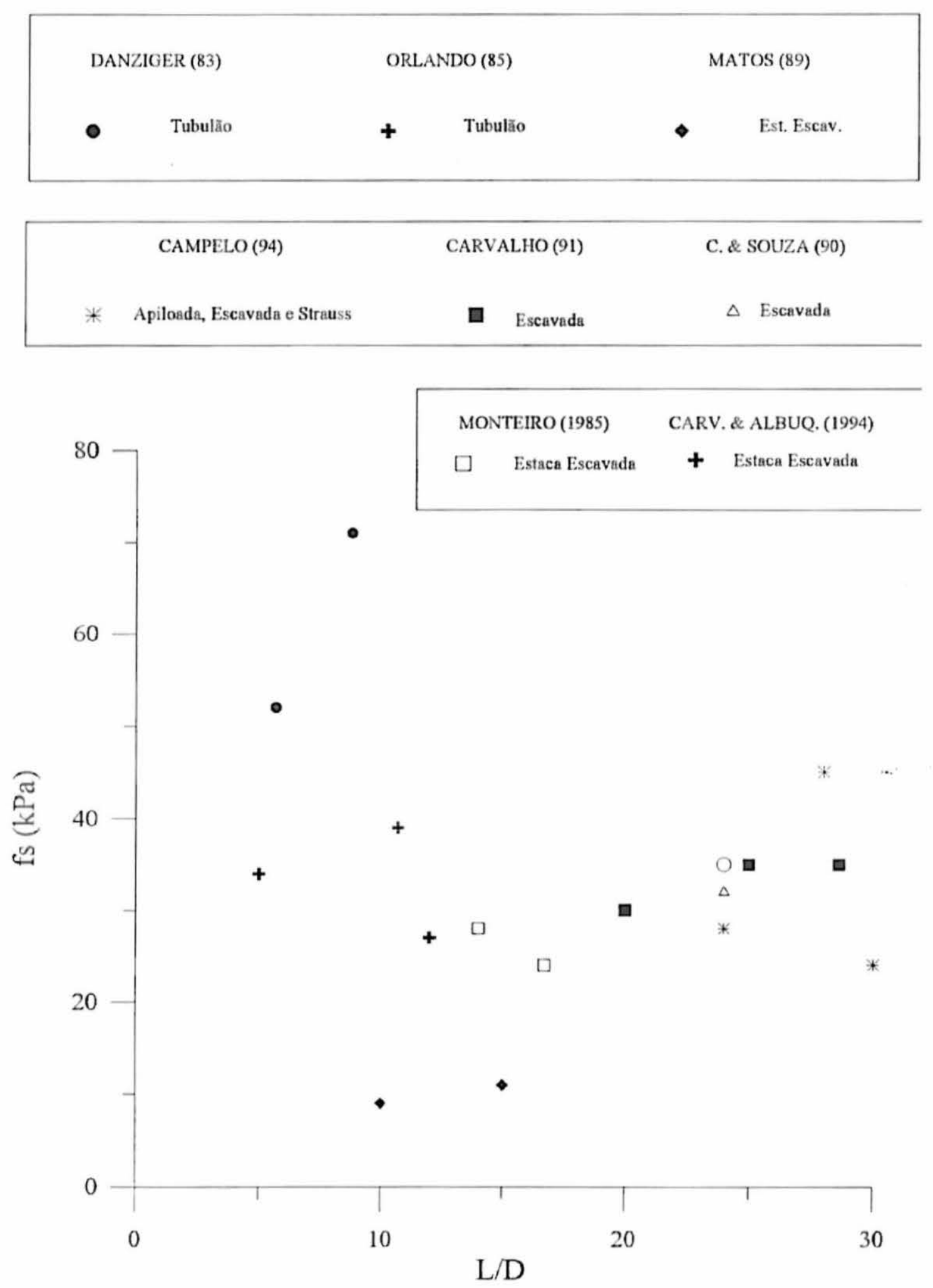

FIGURA 5.11 - Atrito Lateral Total Médio $\left(\mathrm{f}_{\mathrm{S}}\right)$, em Função de L/D. 


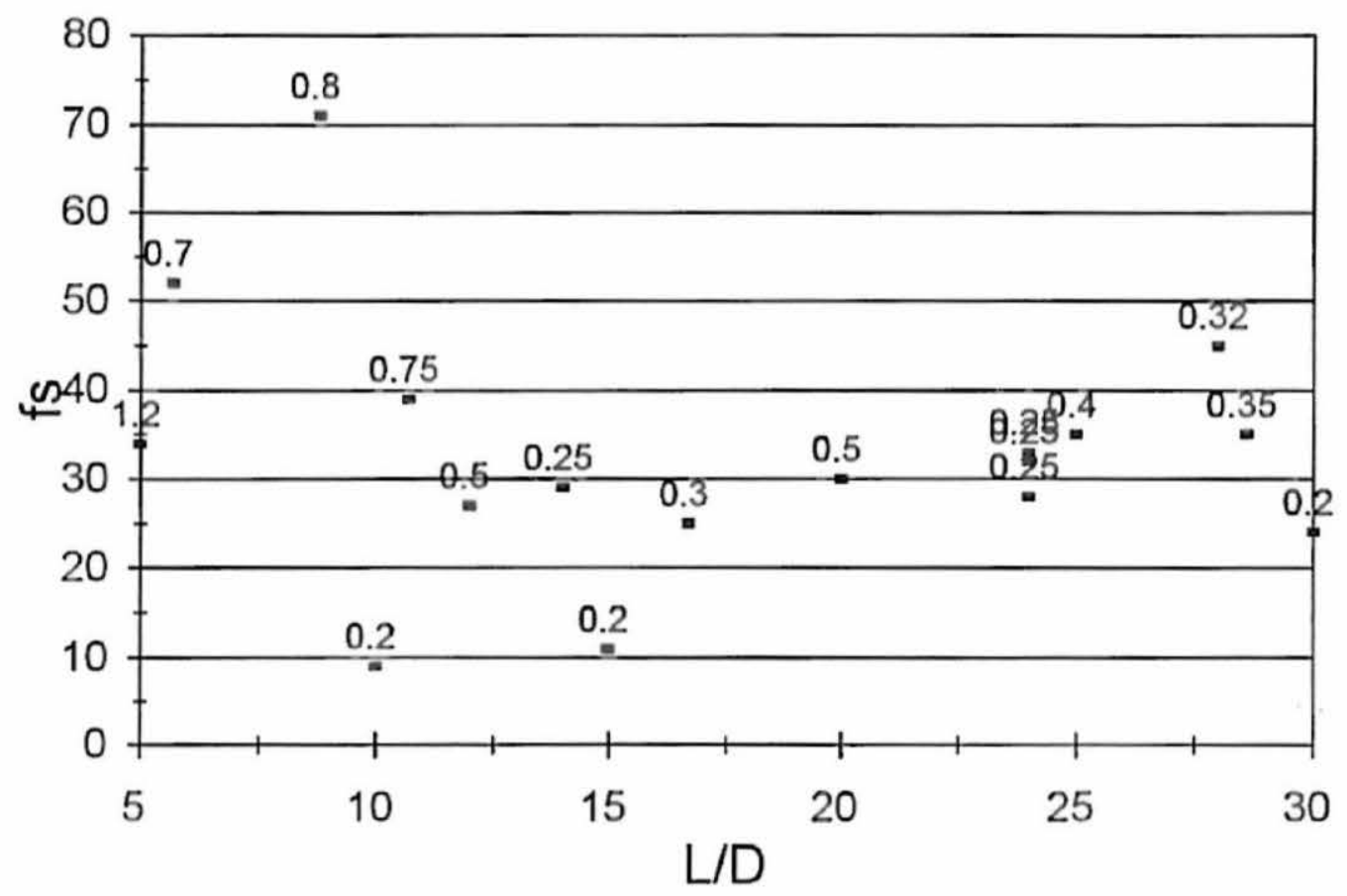

FIGURA 5.12 - Atrito Lateral Total Médio (fs), em Função de L/D e D.

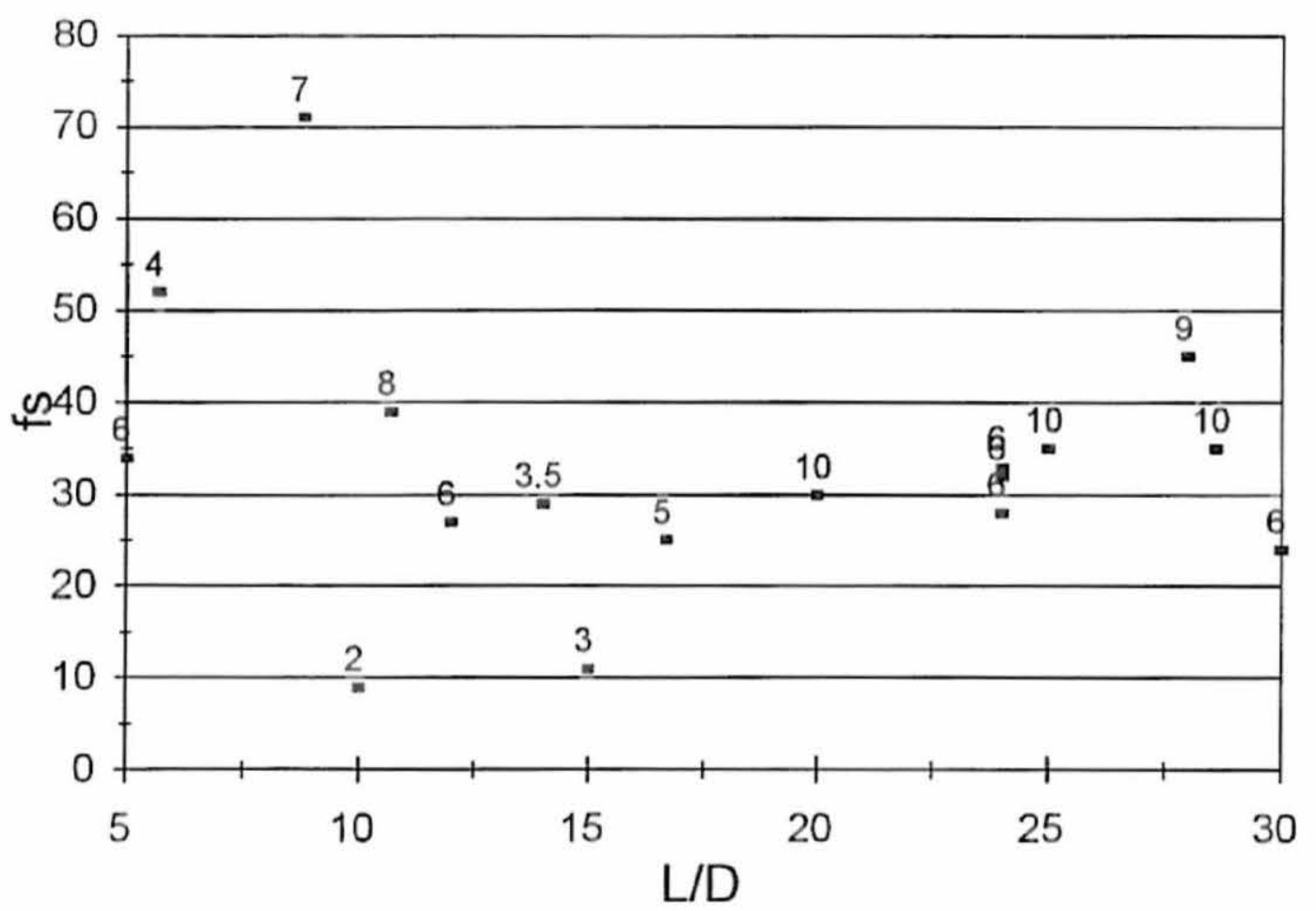

FIGURA 5.13 - Atrito Lateral Total Médio (fs), em função de L/D e L. 


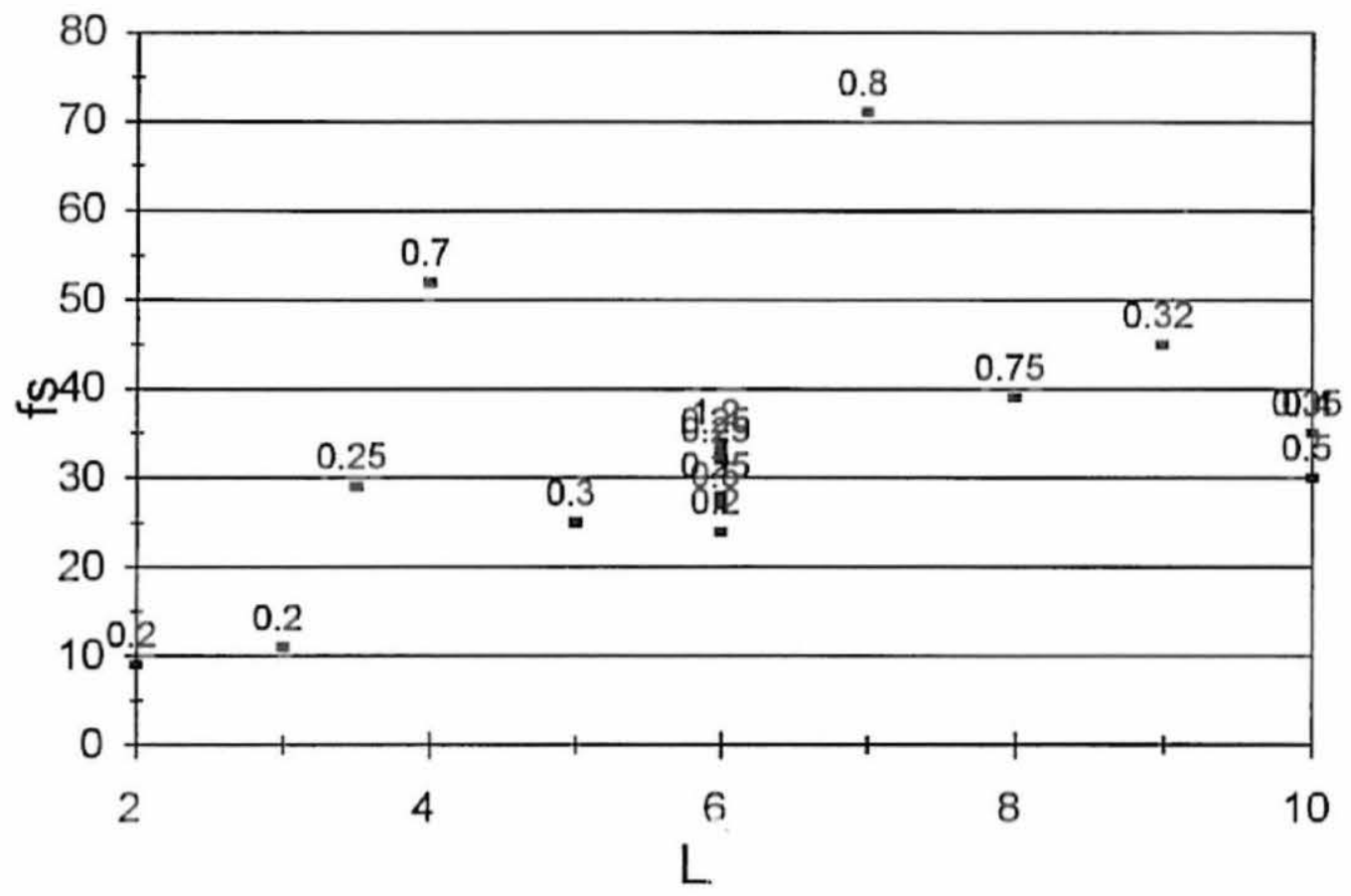

FIGURA 5.14 - Atrito Lateral Total Médio (fs), em Função de L e D.

\subsubsection{Carga última}

Na Figura 5.13 nota-se que, considerando as fundações embutidas no mesmo solo, a diferença nas cargas últimas obtidas, mesmo com coeficientes L/D diferentes, não variaram muito. Nota-se que as três estacas com mesmo coeficiente $L / D$, situadas em solos semelhantes (Ilha Solteira e São Carlos) apresentaram cargas de ruptura praticamente coincidentes. A carga de ruptura da estaca Strauss, com $9 \mathrm{~m}$ de comprimento e $0,32 \mathrm{~m}$ de diâmetro, mostrou-se muito próxima à escavada (CARVALHO, 1991), com comprimento de $10 \mathrm{~m}$ e 0,35 m de diâmetro.

Fato marcante pode ser verificado na comparação entre dois tubulões de dimensões muito próximas, analisados por DANZIGER (1983) e ORLANDO (1985). Os tubulões possuem comprimentos e diâmetros de $7 \mathrm{~m}$ x 0,80 m e $8 \mathrm{~m} \mathrm{x} \mathrm{0,75} \mathrm{m,} \mathrm{mas}$ embutidos em solos distintos - residual e coluvionar, respectivamente. No entanto, a carga de ruptura observada no tubulão embutido no solo residual é praticamente $70 \%$ superior àquela medida no tubulão embutido em solo sedimentar. Obviamente, chama-se a atenção não o fato de diferença encontrada entre as cargas de ruptura, mas sim, a elevada disparidade.

Observando-se as Figuras 5.19, 5.20, 5.21 e 5,22, nota-se que a carga última relaciona-se mais com o diâmetro, que pelo comprimento da fundação, embora de uma forma não muito definida. 


\begin{tabular}{|c|c|c|}
\hline DA NITEER [33] & ORLAMDO [85) & MATOS $[89]$ \\
\hline Q Tubulata & \& Tubular & $E_{\mu \| c a} \Sigma_{2} \mathrm{~cm}=\mathrm{du}$ \\
\hline
\end{tabular}
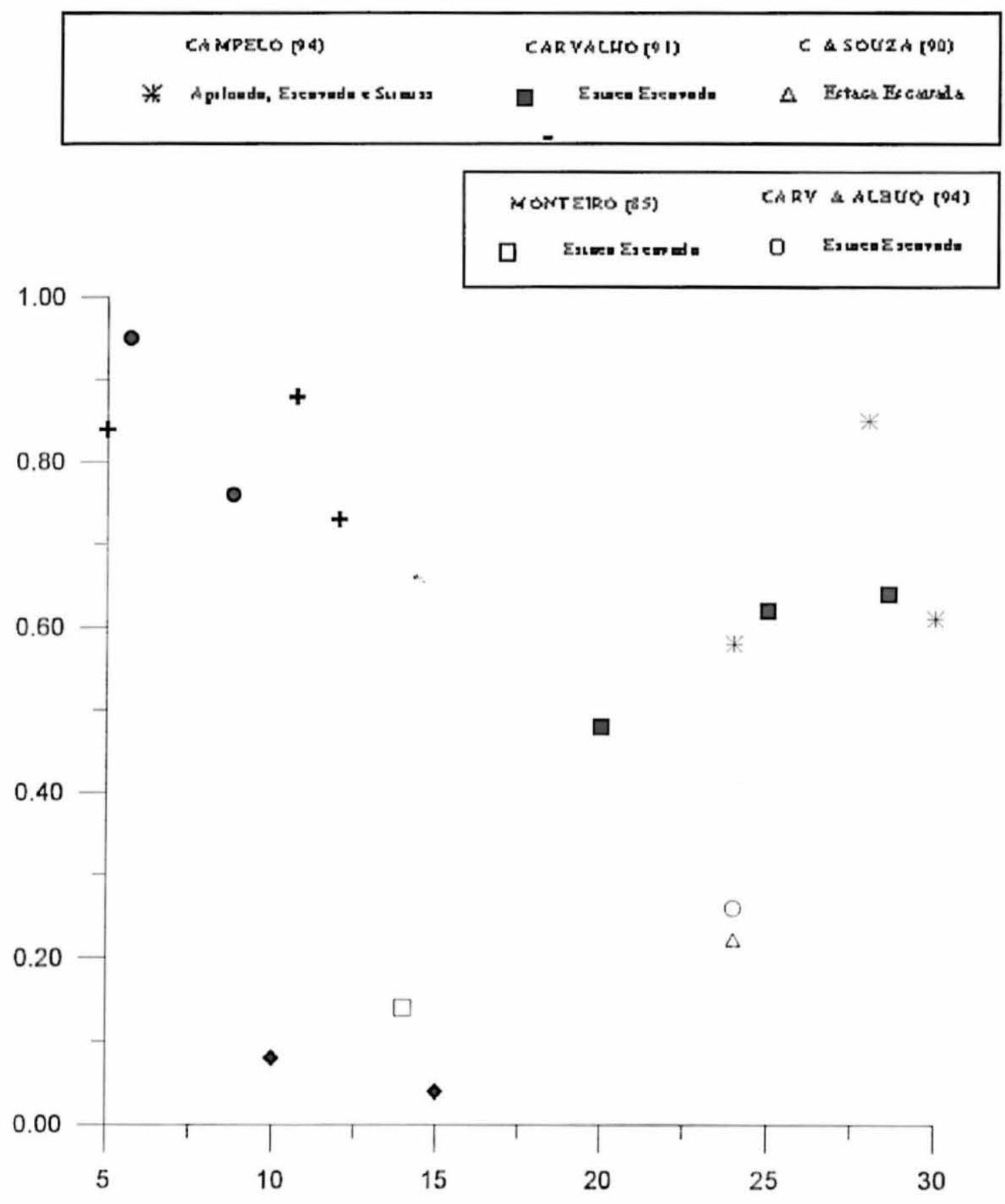

FIGURA 5.15 - Coeficiente de Empuxo $\left(K_{h}\right)$, em Função de L/D. 


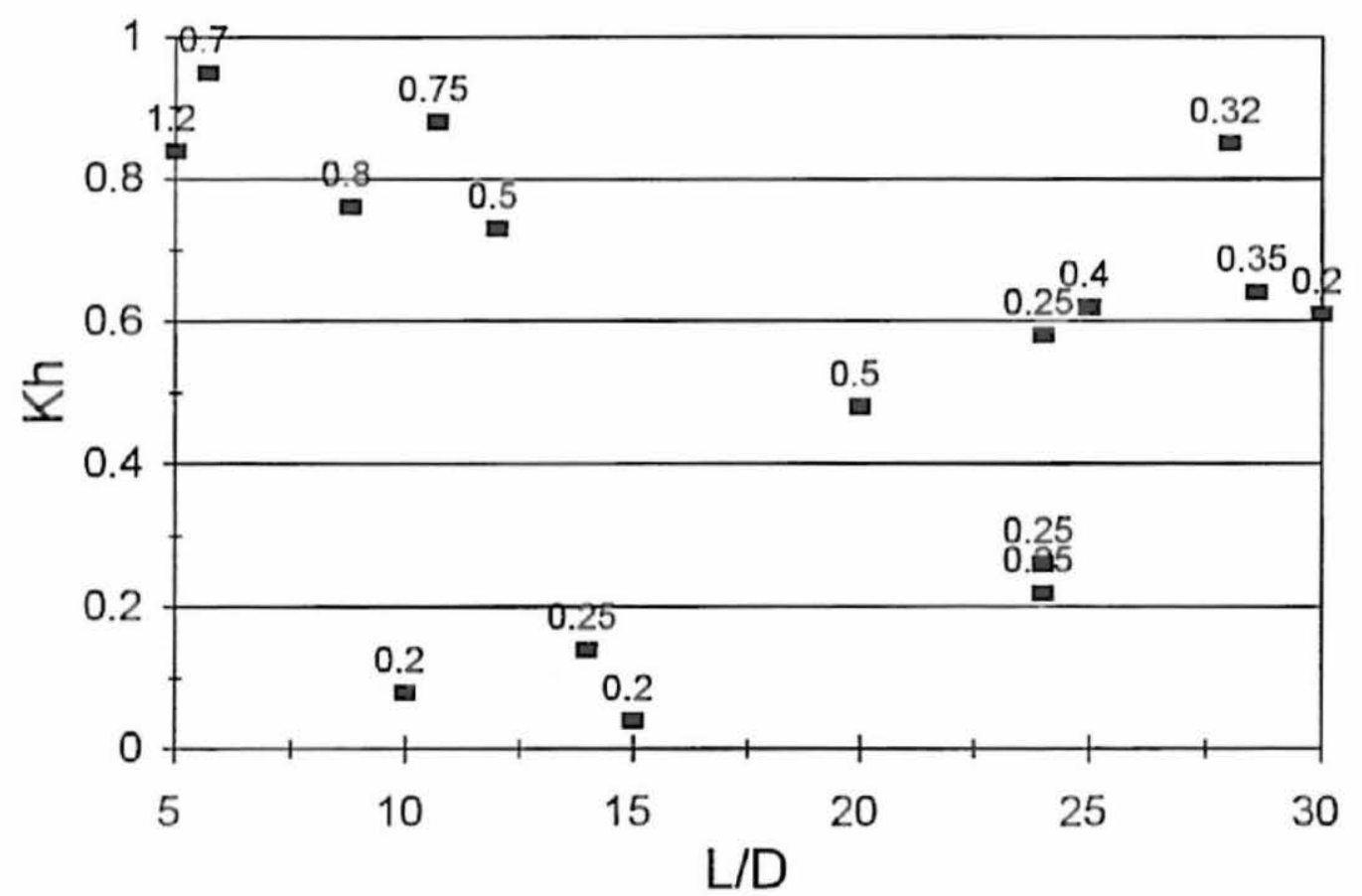

FIGURA 5.16 - Coeficiente de Empuxo (K $\left.\mathrm{K}_{\mathrm{h}}\right)$, em Função de L/D e D.

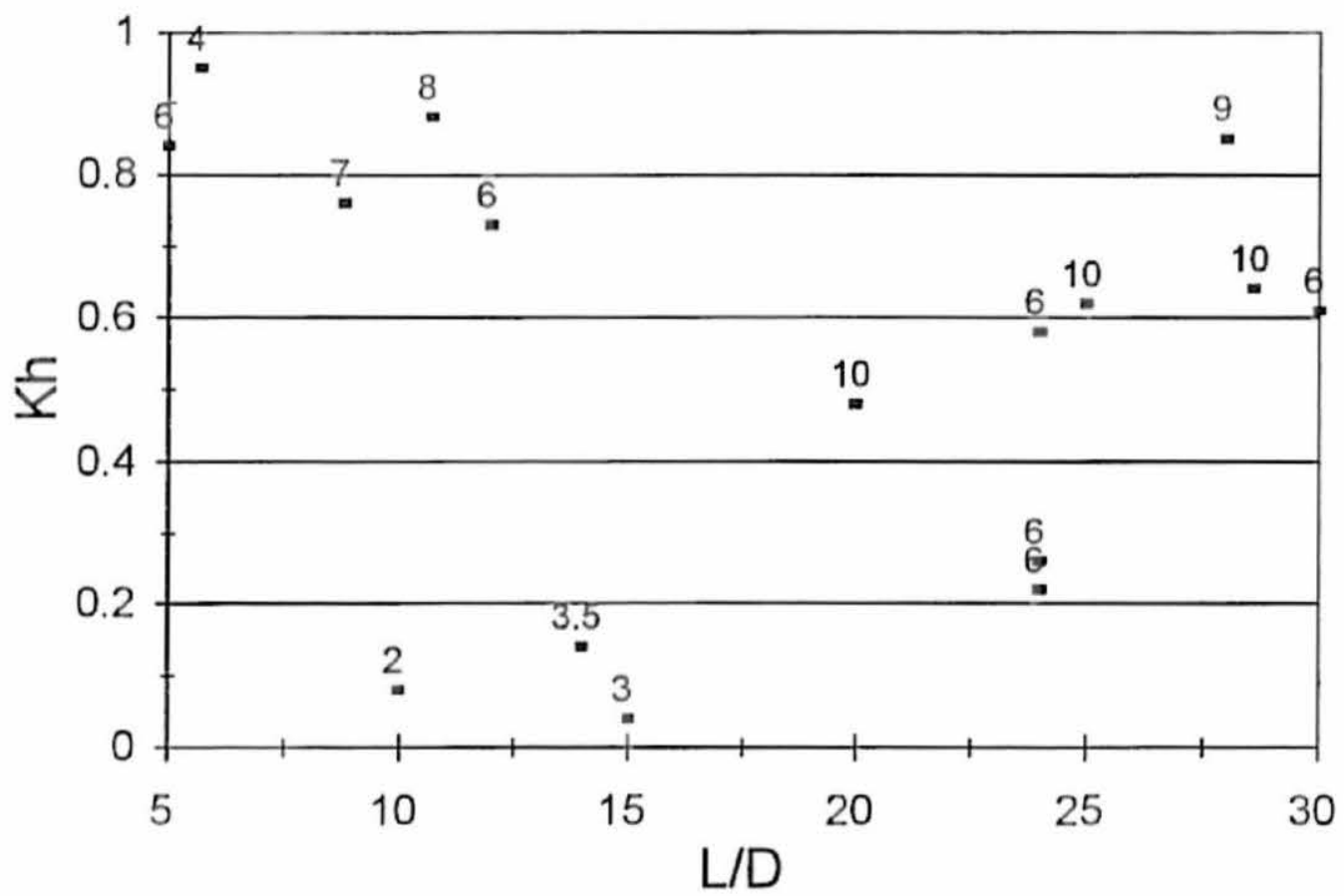

FIGURA 5.17 - Coeficiente de Empuxo $\left(\mathrm{K}_{\mathrm{h}}\right)$, em Função de L/D e L. 


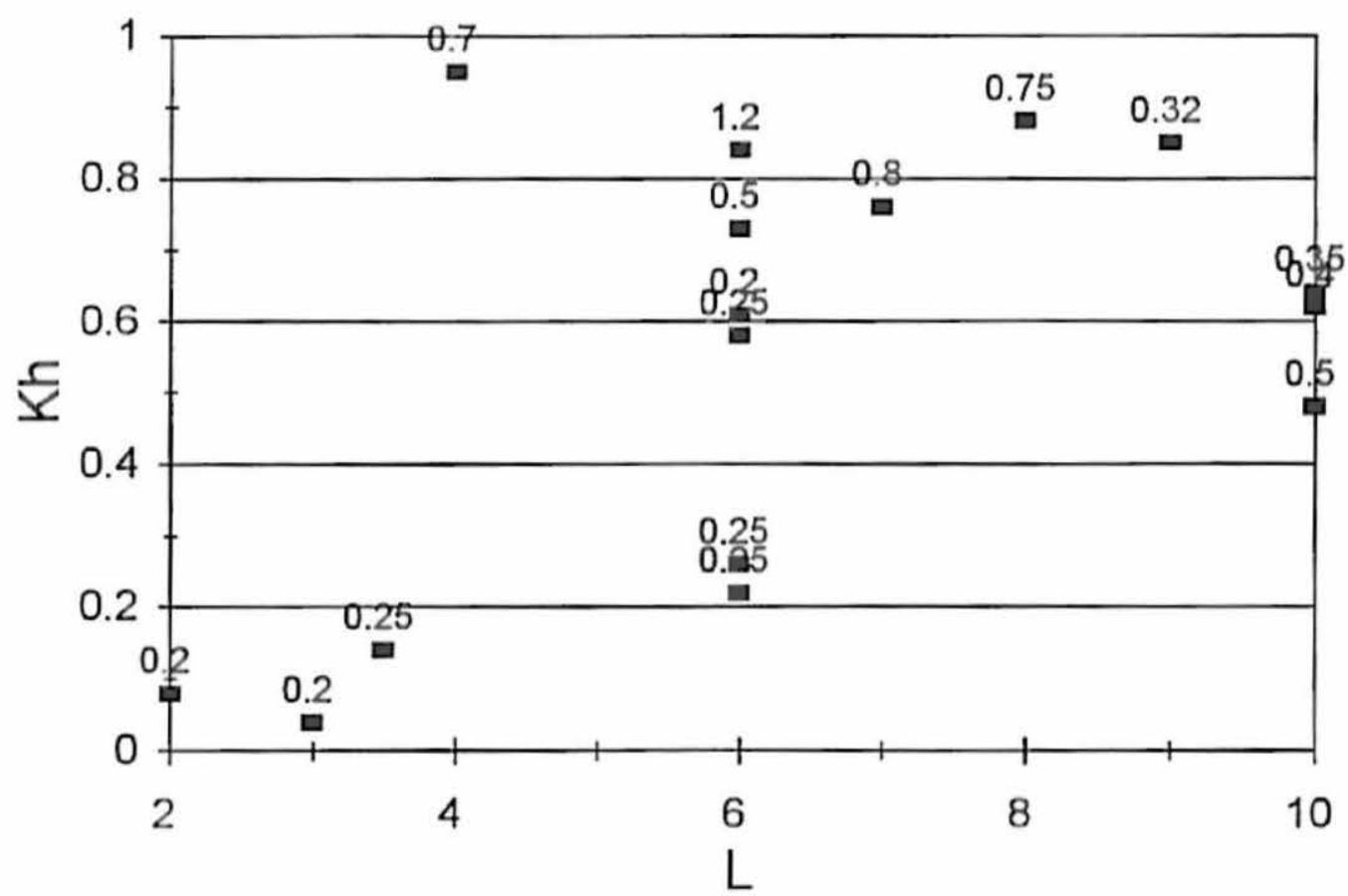

FIGURA 5.18 - Coeficiente de Empuxo $\left(K_{h}\right)$, em Função de L e D.

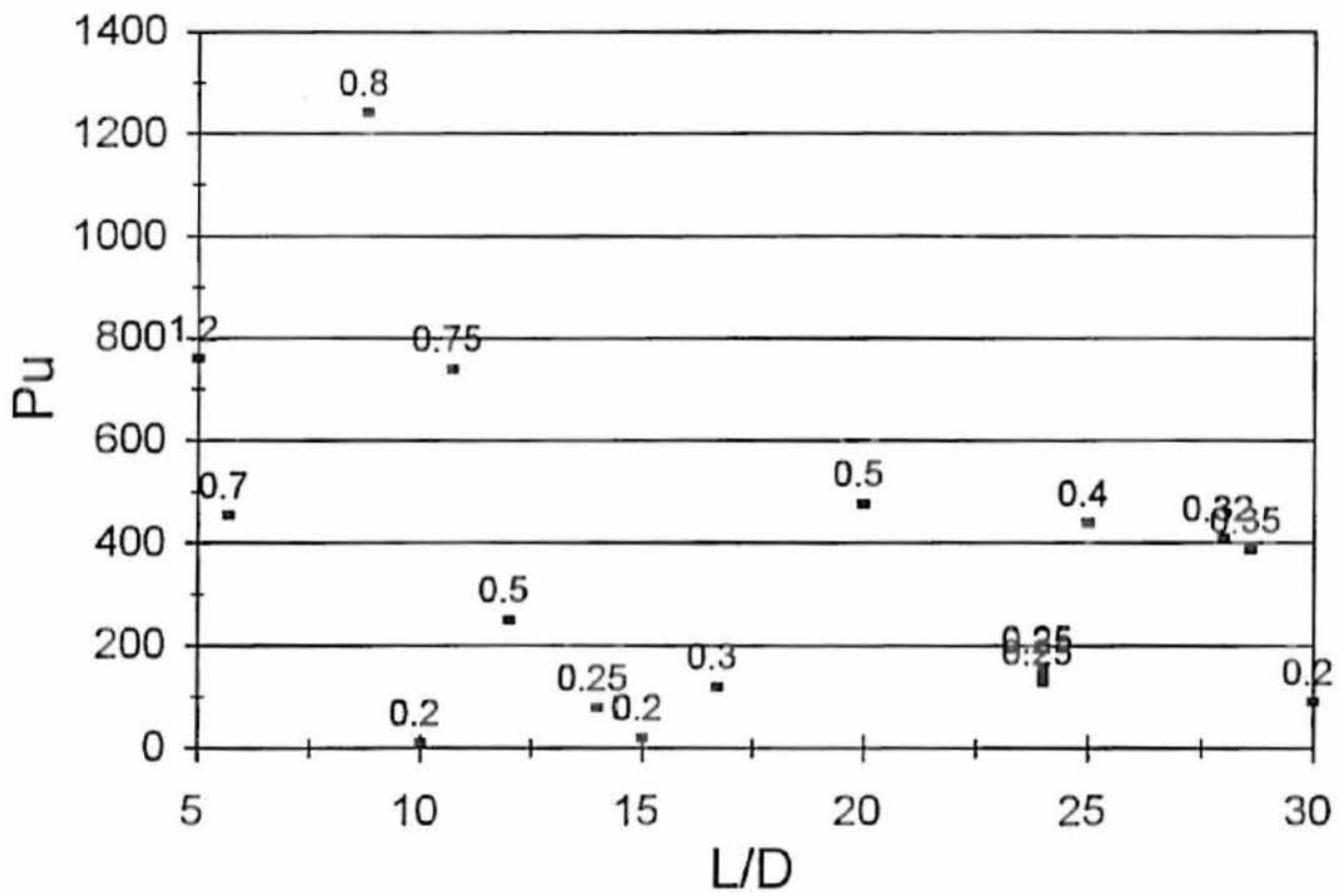

FIGURA 5.19 - Carga de Ruptura (Pu), em Função de L/D e D. 


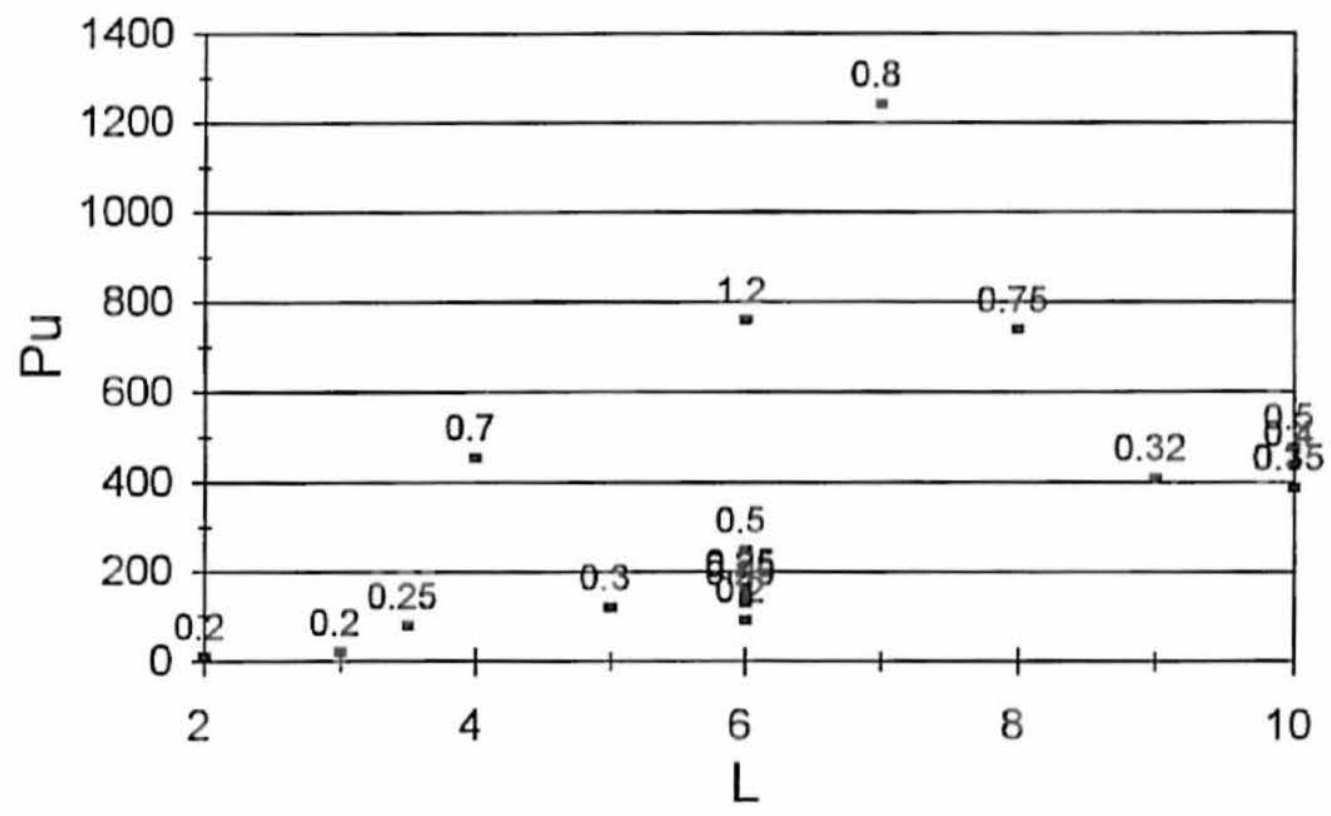

FIGURA 5.20 - Carga de Ruptura, em Função de L e D.

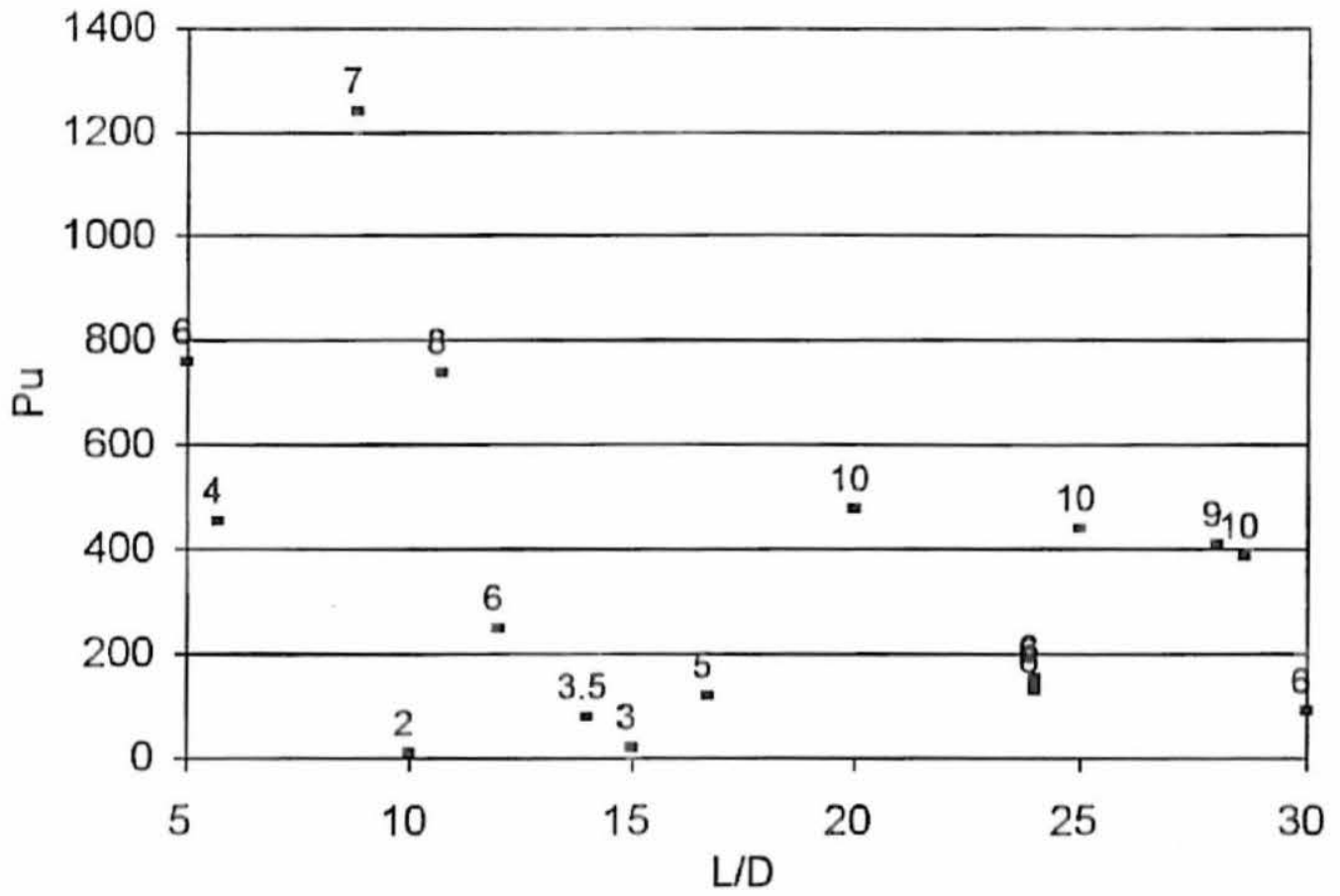

FIGURA 5.21 - Carga de Ruptura ( $\left.\mathrm{P}_{\mathrm{u}}\right)$, em Função de L/D e L. 


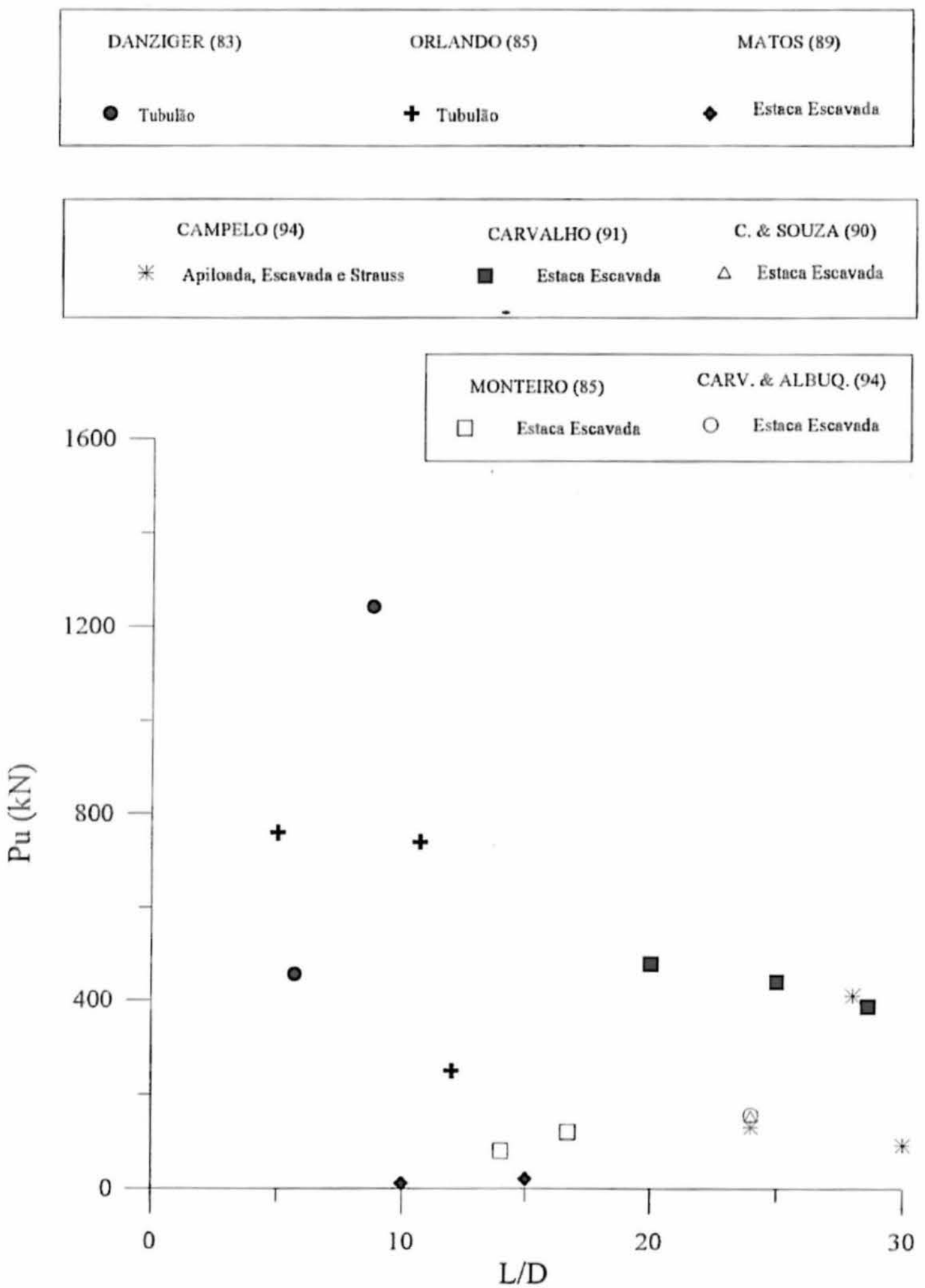

FIGURA 5.22 - Cargas de Ruptura, em Função de L/D. 
DANZIGER (83)

CAMPELO (94)

CARVALHO (91)

- Tubulão

- Apil., Esc. e Strauss

+ Estaca Escavada

$\rho=$ deslocamento $_{50} /$ D. $100 \%$

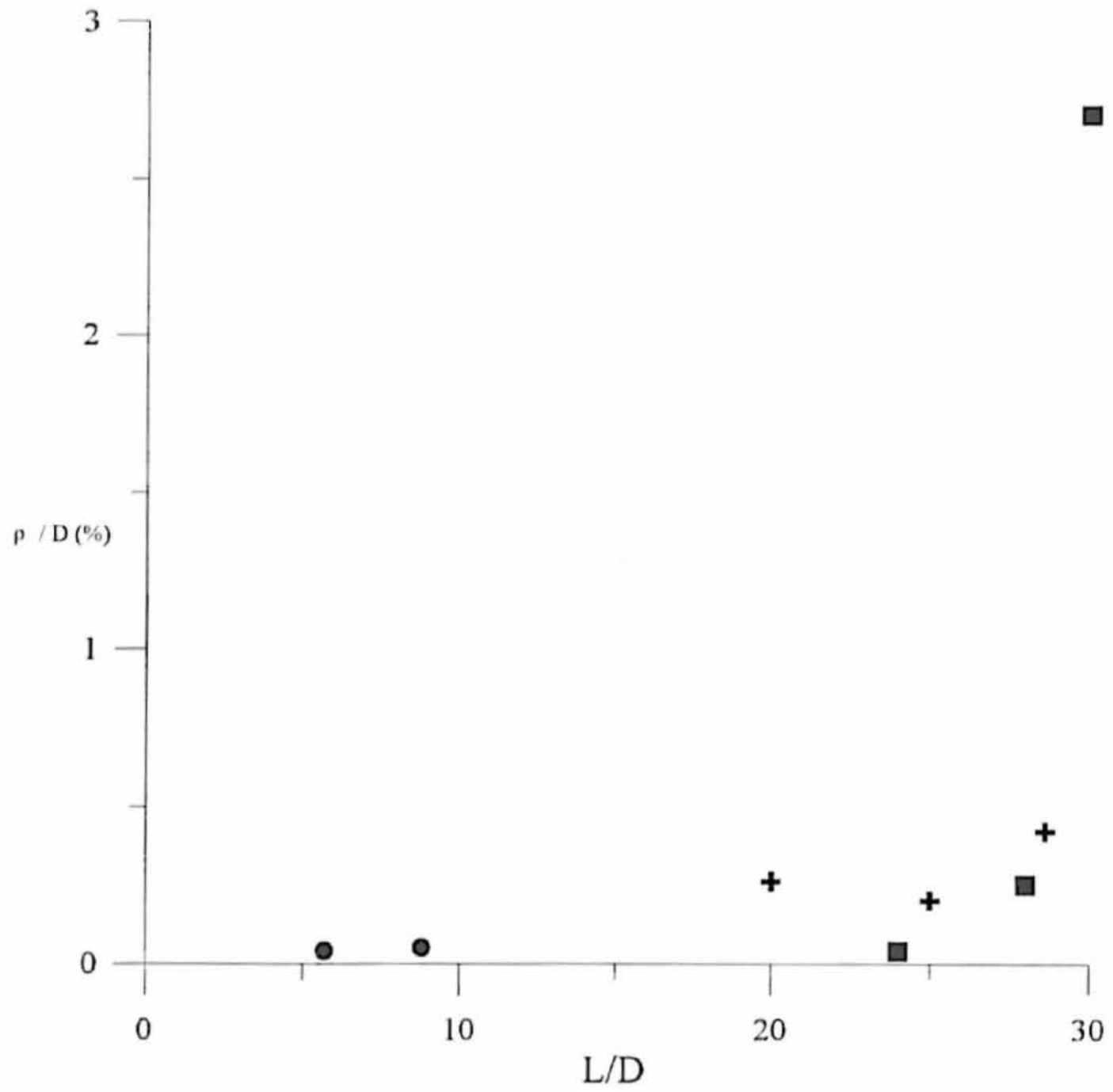

FIGURA 5.23 - Deslocamento na Carga de Trabalho, em Função de L/D e D. 


\section{Capítulo 6}

\section{CONCLUSÕES}

Muitas informações foram colhidas neste trabalho. A comparação dos resultados obtidos, com os de vários outros autores, possibilitou o conhecimento de alguns parâmetros imprescindiveis no dimensionamento de fundações tracionadas.

Alguns métodos de previsão de carga última à tração mostraram-se satisfatórios, com margem de erro tolerável, dentro dos padrões da Engenharia.

Do trabalho exposto, pode-se concluir o seguinte:

1) $O$ apiloamento do solo não foi suficiente para eliminar a sua propensão ao colapso, quando inundado suficientemente até atingir um certo grau de saturação crítico;

2) $\mathrm{O}$ apiloamento, se ineficiente para evitar o colapso do solo, quando inundado, serviu para prorrogar a ocorrência da colapsabilidade da ligação solo-estaca, pois, nas estacas escavadas, os tempos de colapsos foram bem menores;

3) Apesar de que em uma das estacas apiloadas e na do tipo Strauss não ter havido a ocorrência de carga de colapso, na carga de serviço, houve uma diminuição da carga de ruptura, em 40 e 20\%, respectivamente, após 48 h de inundação;

4) $\mathrm{O}$ fato de que em uma das estacas apiloadas não haver ocorrido colapso da ligação solo-estaca, na carga de serviço, talvez possa ser interpretado como uma melhor eficiência na execução dessa estaca, pois, com efeito, um apiloamento mais enérgico pode ter compactado satisfatoriamente o solo ao longo do seu fuste, modificando sua estrutura inicial; 
5) Preferencialmente, em obras de vulto assentes em solo de estrutura colapsivel, as estacas deverão atravessar a camada colapsivel e assentar-se em camadas mais profundas e resistentes do subsolo;

6) Considerando que os colapsos ocorreram para um fator de segurança igual a 2,0 (na carga de trabalho), é conveniente adotar coeficientes maiores, no projeto de fundações tracionadas em solo de estrutura colapsivel, uma vez que CARVALHO \& SOUZA (1990) já verificaram cargas de colapso para 1/3 da carga de ruptura; por outro lado, medidas preventivas podem minimizar os custos que a escolha de um maior coeficiente de segurança traria (CARVALHO \& SOUZA, 1990, TEIXEIRA, 1993);

7) Os deslocamentos médios, na carga de trabalho, apresentaram-se bastante reduzidos, com valores médios de $2,7 \%, 0,04 \%$ e $0,25 \%$ do diâmetro, para as estacas apiloadas, escavadas e Strauss, respectivamente, crescendo com a relação $\mathrm{L} / \mathrm{D}$ da estaca;

8) Com relação ao item anterior, parece razoável crer que o deslocamento não é um fator preponderante no dimensionamento de fundações tracionadas, conforme verificado por vários autores;

9) Com a série de três ensaios na estaca 02, percebeu-se que os deslocamentos diminuiram, para o mesmo nível de carregamento, para o ensaio seguinte;

10) Nessa mesma estaca, o ensaio do tipo rápido conduziu a valores de deslocamentos menores, para as mesmas cargas, que os obtidos no ensaio do tipo lento, corroborando o relato de vários autores sobre o assunto;

11) Os modelos de ruptura que melhor se adaptaram aos resultados experimentais são os que consideram superficie de ruptura cilindrica, na interface solo-estaca, como é o caso dos métodos da Teoria da Resistência Lateral, Grenoble, e o de DAS (com a parcela de adesão incluida);

12) O método do Tronco de Cone mostrou-se muito dispersivo, ora conservador, ora contrario à segurança, mesmo utilizando-se ângulo $\alpha$ próximo ao encontrado por CARVALHO (1991), para estacas de relação L/D semelhantes; 
13) Os valores de $c_{a}$ e $\delta$, conforme preconizado por POTYONDY (1961), levam a resultados satisfatórios, principalmente nos métodos que consideram ruptura na interface solo-estaca;

14) Pela retroanálise efetuada, considerando valores médios obtidos, o método de MEYERHOF (1973) conduzirá a bons resultados se $\mathrm{K}_{\mathrm{u}}$ for minorado para valores próximos ao coeficiente $\mathrm{K}_{0}$, conforme sugerido por JÁKY (1948) ou SAGLEMAR (1975); analogamente, a Teoria da Resistência Lateral propiciará melhores resultados se o coeficiente de empuxo lateral a ser adotado for também próximos ao de repouso. Notou-se que o valor de $\mathrm{K}_{\mathrm{h}}$ é fortemente influenciado pelo tipo de solo e modo de instalação da fundação;

15) O método de MEYERHOF \& ADAMS (1968) apresentou-se conservativo, talvez por ter sido desenvolvido para fundações corridas, muito diferentes das estacas em estudo;

16) O método de Grenoble apresentou bons resultados, considerando ruptura pela interface $(\lambda=0)$, ratificando o que já observaram vários autores; mas para $\lambda=-\phi / 8,0$ método conduziu a resultados contrários à segurança;

17) O método de DAS (1983), desde que acrescido da parcela devida à adesão estaca-solo, fornece também bons resultados de previsão de carga última. Pela média obtida, o coeficiente $\mathrm{K}_{\mathrm{u}}$ demonstrou ser coerente com o preconizado por MEYERHOF (1973a);

18) $\mathrm{O}$ atrito lateral total médio das estacas apiloadas e escavadas, em torno de 30 $\mathrm{kPa}$, situa-se próximo ao encontrado para estacas moldadas in loco, em Ilha Solteira, e tubulões, em Bauru, cujos solos são muito semelhantes aos de São Carlos;

19) Uma relação de ajustamento entre o ângulo $\alpha$ e L/D foi proposta, embora seja um tanto quanto dispersiva. Limites superior e inferior de variação desses parâmetros foram observados, podendo-se adotar, cuidadosamente, a faixa que conduza a valores de previsão mais conservadores, a fim de não afastar-se muito de resultados a favor da segurança;

20) As fundações embutidas no mesmo tipo de solo apresentaram cargas de ruptura próximas, ainda que com relação L/D diferentes. Por outro lado, verificou-se grande 
diferença na carga de ruptura entre dois tubulões com dimensões semelhantes, mas embutidos em solos distintos.

21) O atrito lateral total médio parece guardar melhor relação com o diâmetro da fundação, que com o seu comprimento, não obstante em uma forma não nítida; analogamente, este fato pôde ser verificado quanto à carga de ruptura das fundações. 


\section{Capítulo 7}

\section{SUGESTÕES PARA FUTURAS PESQUISAS}

Em vista do que foi apresentado, e as dúvidas que ainda esperam por esclarecimentos, sugere-se os seguintes pontos como futuras pesquisas:

1. Sabe-se que em alguns solos colapsíveis, os coeficientes de segurança iguais a 2,0 (São Carlos) e 3,0 (Ilha Solteira) não evitaram a colapsibilidade da ligação soloestaca. Far-se-ia mister a inundação do solo para vários coeficientes de segurança, até obter-se o valor minimo de carga que originaria a colapsibilidade (carga de colapso);

2. Relações entre o atrito lateral à tração e à compressão são pouco conhecidos, na literatura nacional. Pesquisas que contassem com estacas instrumentadas à tração e à compressão e relacionassem tanto a carga última total e atrito lateral entre ambos seriam válidos;

3. Parece não haver trabalhos em tração obliqua, em fundações profundas, no nosso país. Dado o grande caso de fundações que enquadram-se nessa categoria, seria conveniente o estudo desses sistemas, com uma comparação experimental das formulações teóricas de previsão de capacidade de carga à tração;

4. A maior parte de ensaios em tração deu-se em tubulões e estacas escavadas. Seria relevante a realização de ensaios em outros tipos de estacas, a fim de ampliar o leque de opções, no uso de fundações profundas mais econômicas, em projetos de fundações tracionadas;

5. Em solos colapsiveis, seria adequado o uso de ensaio de infiltração, a fim de verificar-se a taxa de avanço da frente de umedecimento e, tal qual no caso de fundações comprimidas, tentar correlacionar o recalque da fundação com o avanço da frente de umedecimento. 
ANEXO A

\section{Curva de Calibração}

Célula de 200 kN

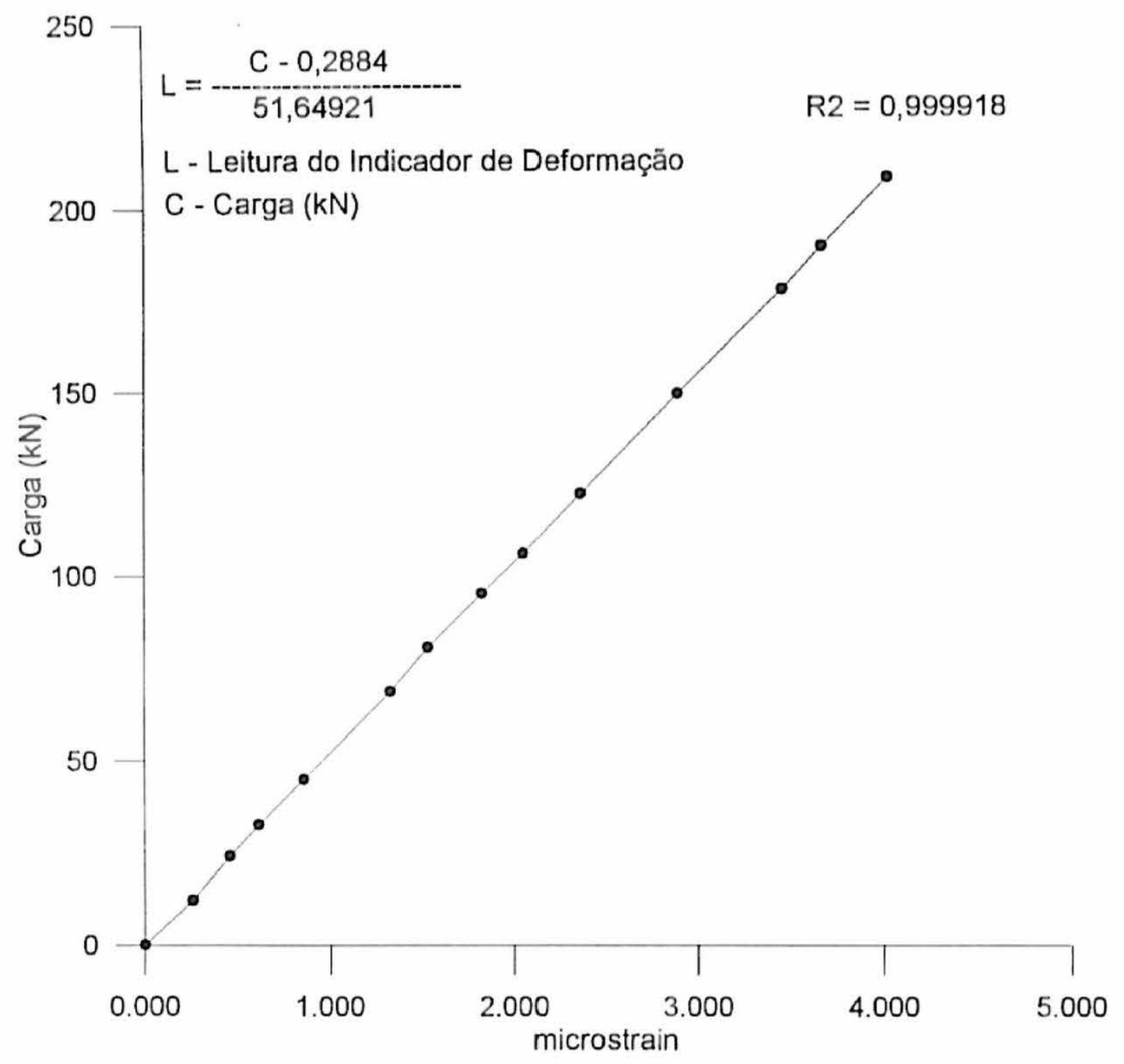


ANEXO B

\section{Curva de Calibração}

Célula de $500 \mathrm{kN}$

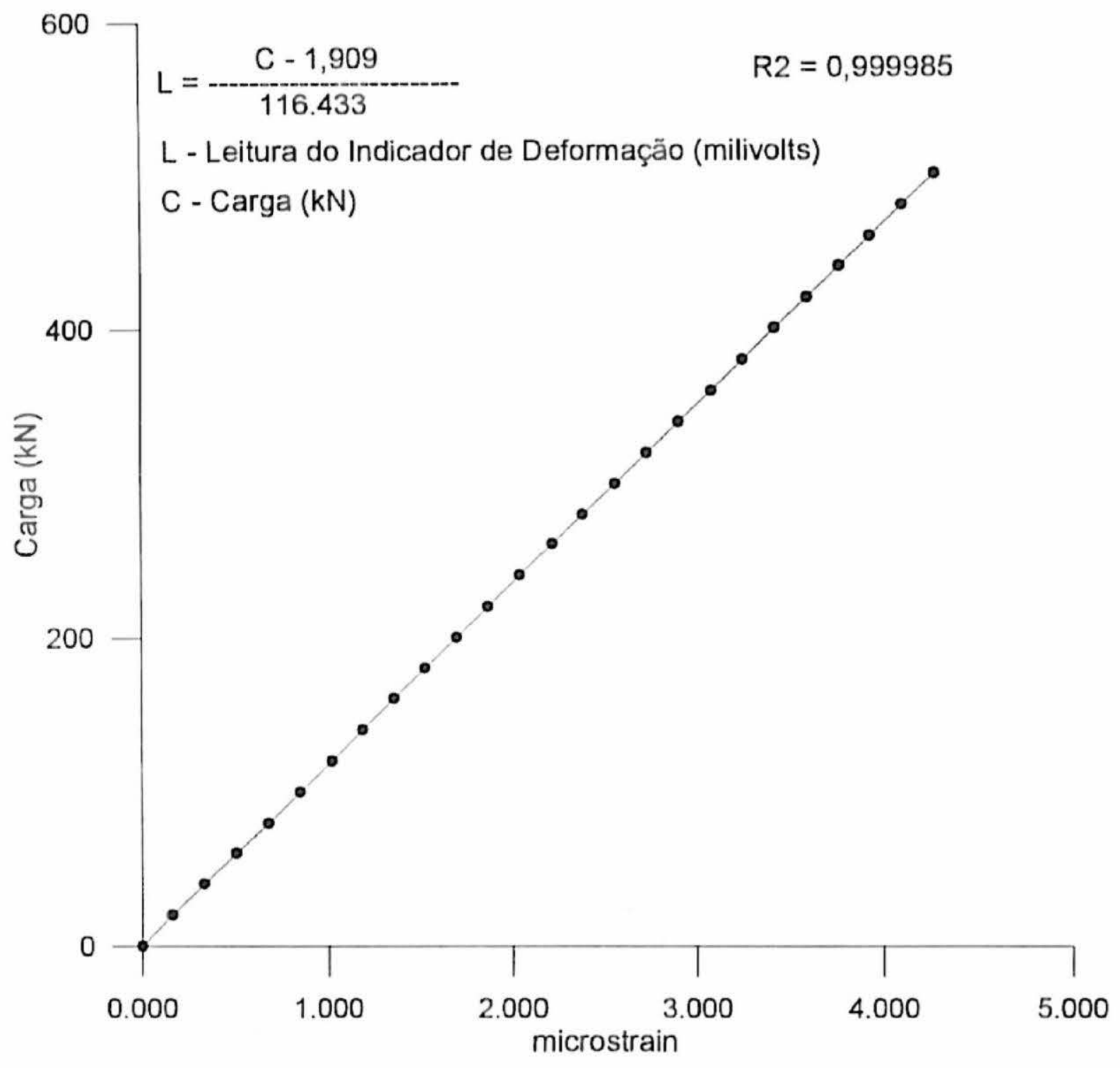




\section{ANEXO C}

Estaca 01 - Apiloada Ensaio Rápido Solo c/ Umidade Natural Data: 02/09/92

\begin{tabular}{|c|c|c|c|c|c|c|}
\hline \multirow{2}{*}{$\begin{array}{l}\text { CARGA } \\
(\mathrm{kN})\end{array}$} & \multicolumn{5}{|c|}{ EXTENSOMETROS ( $\times 10 \mathrm{E}-2 \mathrm{~mm})$} & \multirow{2}{*}{$\begin{array}{c}\text { RECALQUE } \\
(\mathrm{mm})\end{array}$} \\
\hline & 01 & 02 & 03 & 04 & MÉDIA & \\
\hline 0 & & 0 & 0 & 0 & 0 & 0.00 \\
\hline 7 & & 0 & 0 & 0 & 0 & 0.00 \\
\hline 14 & & 0 & 0 & 0 & 0 & 0.00 \\
\hline 21 & & 0 & 2 & 0 & 1 & 0.01 \\
\hline 28 & & 3 & 6 & 3 & 6 & 0.06 \\
\hline 28 & & 6 & 8 & 5 & 9 & 0.09 \\
\hline 35 & & 38 & 38 & 40 & 42 & 0.42 \\
\hline 35 & & 79 & 79 & 83 & 76 & 0.76 \\
\hline 42 & & 132 & 123 & 132 & 129 & 1.29 \\
\hline 42 & & 183 & 182 & 185 & 183 & 1.83 \\
\hline 49 & & 218 & 215 & 220 & 218 & 2.18 \\
\hline 49 & & 300 & 295 & 295 & 297 & 2.97 \\
\hline 56 & & 322 & 315 & 318 & 318 & 3.18 \\
\hline 56 & & 444 & 418 & 414 & 425 & 4.25 \\
\hline 63 & & 458 & 430 & 427 & 438 & 4.38 \\
\hline 63 & & 587 & 552 & 541 & 560 & 5.60 \\
\hline 70 & & 597 & 560 & 550 & 569 & 5.69 \\
\hline 70 & & 788 & 734 & 686 & 736 & 7.36 \\
\hline 77 & & 800 & 742 & 700 & 747 & 7.47 \\
\hline 77 & & 1028 & 894 & 864 & 929 & 9.29 \\
\hline 84 & & 1040 & 904 & 875 & 940 & 9.40 \\
\hline 84 & & 1348 & 1135 & 1124 & 1202 & 12.02 \\
\hline 91 & & 1370 & 1147 & 1146 & 1221 & 12.21 \\
\hline 91 & & 2079 & 1802 & 1767 & 1883 & 18.83 \\
\hline 98 & & 2110 & 1825 & 1800 & 1912 & 19.12 \\
\hline 98 & & 5000 & 4755 & 4720 & 4825 & 48.25 \\
\hline 88.74 & & 5000 & 4889 & 4844 & 4911 & 49.11 \\
\hline 84.68 & & 5000 & 4903 & 4860 & 4921 & 49.21 \\
\hline 36.81 & & 5000 & 4903 & 48.6 & 4921 & 49.21 \\
\hline 37.5 & & 5000 & 4908 & 4857 & 4922 & 49.22 \\
\hline 0 & & 4880 & 4840 & 4870 & 4863 & 48.63 \\
\hline 0 & & 4661 & 4708 & 4754 & 4708 & 47.08 \\
\hline
\end{tabular}




\section{ANEXO D}

Estaca 01 - Ensaio Rápido - Solo Inundado - Cargas Crescentes - Data: 03/09/92

\begin{tabular}{|c|c|c|c|c|c|c|}
\hline \multirow{2}{*}{$\begin{array}{c}\text { CARGA } \\
(\mathrm{kN})\end{array}$} & \multicolumn{5}{|c|}{ EXTENSOMETROS $(\times 10 E-2 \mathrm{~mm})$} & \multirow{2}{*}{$\begin{array}{l}\text { RECALQUE } \\
(\mathrm{mm})\end{array}$} \\
\hline & 01 & 02 & 03 & 04 & MÉDIA & \\
\hline & & & & & & \\
\hline 0 & 0 & 0 & 0 & 0 & 0 & 0.00 \\
\hline 7 & 2 & 0 & 0 & 0 & 0 & 0.00 \\
\hline 14 & 14 & 2 & 0 & 5 & 5 & 0.05 \\
\hline 14 & 16 & 5 & 0 & 5 & 6 & 0.06 \\
\hline 21 & 42 & 33 & 12 & 20 & 27 & 0.27 \\
\hline 21 & 45 & 35 & 13 & 21 & 29 & 0.29 \\
\hline 28 & 88 & 71 & 28 & 45 & 58 & 0.58 \\
\hline 28 & 95 & 78 & 36 & 52 & 65 & 0.65 \\
\hline 35 & 125 & 105 & 50 & 69 & 87 & 0.87 \\
\hline 35 & 145 & 120 & 63 & 80 & 102 & 1.02 \\
\hline 42 & 165 & 145 & 68 & 94 & 118 & 1.18 \\
\hline 42 & 178 & 155 & 76 & 101 & 128 & 1.28 \\
\hline 42 & 187 & 168 & 86 & 107 & 137 & 1.37 \\
\hline 49 & 195 & 176 & 86 & 107 & 141 & 1.41 \\
\hline 49 & 215 & 188 & 93 & 107 & 170 & 1.70 \\
\hline 56 & 228 & 193 & -- & 116 & 179 & 1.79 \\
\hline 56 & 266 & 230 & 252 & 223 & 243 & 2.43 \\
\hline 63 & 274 & 232 & 252 & 223 & 245 & 2.45 \\
\hline 63 & 307 & 243 & 260 & 241 & 263 & 2.63 \\
\hline 70 & 337 & 250 & 274 & 249 & 278 & 2.78 \\
\hline 70 & 400 & 297 & 326 & 308 & 333 & 3.33 \\
\hline 77 & 410 & 308 & 336 & 318 & 343 & 3.43 \\
\hline 77 & 1460 & 1300 & 1242 & 1220 & 1306 & 13.06 \\
\hline 74.28 & 1468 & 1320 & 1255 & 1230 & 1318 & 13.18 \\
\hline 71.74 & 1480 & 1330 & 1272 & 1251 & 1333 & 13.33 \\
\hline 36.04 & 1400 & 1320 & 1269 & 1263 & 1313 & 13.13 \\
\hline 33.34 & 1395 & 1315 & 1264 & 1238 & 1303 & 13.03 \\
\hline 0 & 1000 & 970 & 1037 & 1085 & 1023 & 10.23 \\
\hline 0 & 977 & 952 & 1014 & 1069 & 1003 & 10.03 \\
\hline
\end{tabular}




\section{ANEXO E}

Estaca 01 - Ensaio Rápido - Solo Inund. na Carga de Trabalho - Data: 08/10/92

\begin{tabular}{|c|c|c|c|c|c|c|}
\hline \multirow{2}{*}{$\begin{array}{c}\text { CARGA } \\
(\mathrm{KN})\end{array}$} & \multicolumn{5}{|c|}{ EXTENSOMETROS ( $\times 10 \mathrm{E}-2 \mathrm{~mm})$} & \multirow{2}{*}{$\begin{array}{l}\text { RECALQUE } \\
(\mathrm{mm})\end{array}$} \\
\hline & 01 & 02 & 03 & 04 & MÉDIA & \\
\hline 0 & 0 & 0 & 0 & 0 & 0 & 0.00 \\
\hline 7 & 1 & 1 & $\underline{0}$ & 0 & 0.5 & 0.01 \\
\hline 7 & 1 & 1 & 1 & 0 & 0.75 & 0.01 \\
\hline 14 & 20 & 14 & 2 & 0 & 9 & 0.09 \\
\hline 14 & 20 & 19 & 2 & 0 & 10.25 & 0.10 \\
\hline 21 & 73 & 73 & 28 & 44 & 54.5 & 0.55 \\
\hline 21 & 73 & 82 & 40 & 55 & 62.5 & 0.63 \\
\hline 28 & 126 & 123 & 65 & 84 & 99.5 & 1.00 \\
\hline 28 & 145 & 135 & 80 & 104 & 116 & 1.16 \\
\hline 35 & 184 & 168 & 104 & 134 & 147.5 & 1.48 \\
\hline 35 & 194 & 178 & 116 & 147 & 158.75 & 1.59 \\
\hline 42 & 227 & 195 & 132 & 171 & 181.25 & 1.81 \\
\hline 42 & 235 & 205 & 145 & 181 & 191.5 & 1.92 \\
\hline 49 & 261 & 219 & 156 & 181 & 204.25 & 2.04 \\
\hline 49 & 295 & 240 & 177 & 200 & 228 & 2.28 \\
\hline 49 & 359 & 291 & 230 & 301 & 295.25 & 2.95 \\
\hline 56 & 359 & 291 & 230 & 301 & 295.25 & 2.95 \\
\hline 56 & 383 & 314 & 250 & 301 & 312 & 3.12 \\
\hline 63 & 423 & 358 & 282 & 301 & 341 & 3.41 \\
\hline 63 & 4350 & 4310 & 4175 & 4272 & 4276.75 & 42.77 \\
\hline 60.56 & 4360 & 4317 & 4186 & 4278 & 4285.25 & 42.85 \\
\hline 59.08 & 4365 & 4321 & 4190 & 4282 & 4289.5 & 42.90 \\
\hline 33.71 & 4356 & 4317 & 4192 & 4273 & 4284.5 & 42.85 \\
\hline 34.08 & 4356 & 4317 & 4192 & 4271 & 4284 & 42.84 \\
\hline 0 & 4055 & 4045 & 4070 & 4010 & 4045 & 40.45 \\
\hline 0 & 3990 & 3978 & 4016 & 3950 & 3983.5 & 39.84 \\
\hline
\end{tabular}




\section{ANEXO F}

Estaca 02 - Ensaio lento - Solo c/ Umidade Natural - Data: 13/10/92

\begin{tabular}{|c|c|c|c|c|c|c|}
\hline \multirow{2}{*}{$\begin{array}{c}\text { CARGA } \\
(\mathrm{kN})\end{array}$} & \multicolumn{5}{|c|}{ EXTENSOMETROS ( $\times 10 \mathrm{E}-2 \mathrm{~mm})$} & \multirow{2}{*}{$\begin{array}{c}\text { RECALQUE } \\
(\mathrm{mm})\end{array}$} \\
\hline & 1 & 2 & 3 & 4 & MÉDIA & \\
\hline 0 & & 0 & 0 & 0 & 0 & 0.00 \\
\hline 10 & & 0 & 0 & 0 & 0 & 0.00 \\
\hline 20 & & 3 & 1 & 5 & 3 & 0.03 \\
\hline 20 & & 3 & 1 & 9 & 4 & 0.04 \\
\hline 30 & & 15 & 21 & 14 & 17 & 0.17 \\
\hline 30 & & 58 & 60 & 74 & 64 & 0.64 \\
\hline 40 & & 120 & 121 & 125 & 122 & 1.22 \\
\hline 40 & & 201 & 207 & 224 & 211 & 2.11 \\
\hline 50 & & 260 & 261 & 275 & 265 & 2.65 \\
\hline 50 & & 395 & 409 & 430 & 411 & 4.11 \\
\hline 60 & & 430 & 451 & 470 & 450 & 4.50 \\
\hline 60 & & 760 & 798 & 827 & 795 & 7.95 \\
\hline 70 & & 775 & 811 & 840 & 809 & 8.09 \\
\hline 70 & & 4627 & 4660 & 4770 & 4686 & 46.86 \\
\hline 65.65 & & 4642 & 4675 & 4790 & 4702 & 47.02 \\
\hline 63.27 & & 4652 & 4685 & 4800 & 4712 & 47.12 \\
\hline 32.5 & & 4590 & 4688 & 4800 & 4693 & 46.93 \\
\hline 33 & & 4589 & 4688 & 4800 & 4692 & 46.92 \\
\hline 0 & & 4445 & 4505 & 4600 & 4517 & 45.17 \\
\hline 0 & & 4400 & 4470 & 4567 & 4479 & 44.79 \\
\hline
\end{tabular}




\section{ANEXO G}

Estaca 02 - Ensaio Lento - Solo Inund. na Carga de Trabalho - Data:16/10/92

\begin{tabular}{|c|c|c|c|c|c|c|}
\hline \multirow{2}{*}{$\begin{array}{c}\text { CARGA } \\
(\mathrm{kN})\end{array}$} & \multicolumn{5}{|c|}{ EXTENSOMETROS ( $10 \mathrm{E}-2 \mathrm{~mm})$} & \multirow{2}{*}{$\begin{array}{l}\text { RECALQUE } \\
(\mathrm{mm})\end{array}$} \\
\hline & 1 & 2 & 3 & 4 & MÉDIA & \\
\hline 0 & 0 & 0 & 0 & 0 & 0 & 0.00 \\
\hline 5 & 1 & 0 & 1 & 0 & 0.5 & 0.01 \\
\hline 10 & 11 & 0 & 8 & 10 & 7.25 & 0.07 \\
\hline 10 & 18 & 0 & 13 & 14 & 11.25 & 0.11 \\
\hline 15 & 55 & 27 & 38 & 50 & 42.5 & 0.43 \\
\hline 15 & 64 & 38 & 53 & 58 & 53.25 & 0.53 \\
\hline 20 & 95 & 64 & 79 & 90 & 82 & 0.82 \\
\hline 20 & 107 & 80 & 93 & 100 & 95 & 0.95 \\
\hline 25 & 130 & 98 & 108 & 120 & 114 & 1.14 \\
\hline 25 & 145 & 114 & 126 & 136 & 130.25 & 1.30 \\
\hline 30 & 155 & 124 & 134 & 145 & 139.5 & 1.40 \\
\hline 30 & 170 & 137 & 148 & 160 & 153.75 & 1.54 \\
\hline 35 & 180 & 147 & 158 & 175 & 165 & 1.65 \\
\hline 35 & 4540 & 4425 & 4320 & 4502 & 4446.75 & 44.47 \\
\hline 33.87 & 4556 & 4439 & 4336 & 4515 & 4461.5 & 44.62 \\
\hline 32.55 & 4565 & 4448 & 4343 & 4522 & 4469.5 & 44.70 \\
\hline 16.29 & 4565 & 4448 & 4343 & 4522 & 4469.5 & 44.70 \\
\hline 16.55 & 4565 & 4448 & 4343 & 4522 & 4469.5 & 44.70 \\
\hline 0 & 4340 & 4230 & 4125 & 4300 & 4248.75 & 42.49 \\
\hline 0 & 4278 & 4173 & 4085 & 4260 & 4199 & 41.99 \\
\hline
\end{tabular}


ANEXO H

Estaca 03 - Ensaio Rápido - Solo c/ Umidade Natural - Data: 04/11/92

\begin{tabular}{|c|c|c|c|c|c|c|}
\hline \multirow{2}{*}{$\begin{array}{c}\text { CARGA } \\
(\mathrm{kN})\end{array}$} & \multicolumn{7}{|c|}{ EXTENSOMETROS $(\mathrm{x} 10 \mathrm{E}-2 \mathrm{~mm})$} & \multirow{2}{*}{$\begin{array}{c}\text { RECALQUE } \\
(\mathrm{mm})\end{array}$} \\
\hline & 1 & 2 & 3 & 4 & MEDIA & 0.00 \\
\hline 3.5 & 0 & 0 & 0 & 0 & 0.0 & 0.00 \\
\hline 7 & 0 & 0 & 0 & 0 & 0.0 & 0.00 \\
\hline 10.5 & 0 & 0 & 3 & 0 & 0.0 & 0.00 \\
\hline 14 & 0 & 0 & 4 & 0 & 0.0 & 0.00 \\
\hline 17.5 & 0 & 0 & 5 & 0 & 0.0 & 0.00 \\
\hline 21 & 0 & 0 & 6 & 0 & 0.0 & 0.00 \\
\hline 21 & 0 & 7 & 12 & 0 & 2.3 & 0.02 \\
\hline 24.5 & 0 & 7 & 12 & 0 & 2.3 & 0.02 \\
\hline 28 & 0 & 7 & 12 & 0 & 2.3 & 0.02 \\
\hline 28 & 0 & 7 & 15 & 0 & 2.3 & 0.02 \\
\hline 31.5 & 0 & 13 & 18 & 0 & 4.3 & 0.04 \\
\hline 35 & 0 & 13 & 20 & 0 & 4.3 & 0.04 \\
\hline 35 & 0 & 17 & 23 & 0 & 5.7 & 0.06 \\
\hline 38.5 & 0 & 17 & 23 & 0 & 5.7 & 0.06 \\
\hline 38.5 & 0 & 21 & 28 & 0 & 7.0 & 0.07 \\
\hline 42 & 0 & 21 & 28 & 0 & 7.0 & 0.07 \\
\hline 42 & 0 & 21 & 30 & 2 & 7.7 & 0.08 \\
\hline 45.5 & 0 & 21 & 30 & 2 & 7.7 & 0.08 \\
\hline 45.5 & 0 & 25 & 33 & 3 & 9.3 & 0.09 \\
\hline 49 & 0 & 25 & 33 & 3 & 9.3 & 0.09 \\
\hline 49 & 0 & 27 & 36 & 4 & 10.3 & 0.10 \\
\hline 52.5 & 0 & 27 & 37 & 5 & 10.7 & 0.11 \\
\hline 52.5 & 1 & 32 & 41 & 7 & 13.3 & 0.13 \\
\hline 56 & 1 & 32 & 41 & 7 & 13.3 & 0.13 \\
\hline 56 & 2 & 36 & 45 & 7 & 15.0 & 0.15 \\
\hline 59.5 & 2 & 36 & 45 & 7 & 15.0 & 0.15 \\
\hline 59.5 & 4 & 36 & 47 & 9 & 16.3 & 0.16 \\
\hline 63 & 5 & 42 & 50 & 10 & 19.0 & 0.19 \\
\hline 66.5 & 6 & 46 & 55 & 11 & 21.0 & 0.21 \\
\hline 66.5 & 7 & 52 & 56 & 12 & 23.7 & 0.24 \\
\hline 70 & 7 & 52 & 56 & 12 & 23.7 & 0.24 \\
\hline
\end{tabular}




\section{ANEXO H}

\begin{tabular}{|c|c|c|c|c|c|c|}
\hline 70 & 10 & 56 & 56 & 17 & 27.7 & 0.28 \\
\hline 73.5 & 10 & 59 & 56 & 18 & 29.0 & 0.29 \\
\hline 73.5 & 13 & 64 & 56 & 20 & 32.3 & 0.32 \\
\hline 77 & 13 & 64 & 56 & 21 & 32.7 & 0.33 \\
\hline 77 & 19 & 72 & 56 & 27 & 39.3 & 0.39 \\
\hline 80.5 & 19 & 72 & 56 & 27 & 39.3 & 0.39 \\
\hline 80.5 & 23 & 78 & 57 & 32 & 44.3 & 0.44 \\
\hline 84 & 24 & 81 & 57 & 33 & 46.0 & 0.46 \\
\hline 84 & 30 & 88 & 57 & 40 & 52.7 & 0.53 \\
\hline 87.5 & 30 & 88 & 57 & 40 & 52.7 & 0.53 \\
\hline 87.5 & 38 & 95 & 57 & 49 & 60.7 & 0.61 \\
\hline 91 & 39 & 96 & 57 & 50 & 61.7 & 0.62 \\
\hline 91 & 50 & 108 & 57 & 61 & 73.0 & 0.73 \\
\hline 94.5 & 50 & 109 & 57 & 62 & 73.7 & 0.74 \\
\hline 94.5 & 70 & 128 & 57 & 82 & 93.3 & 0.93 \\
\hline 98 & 73 & 130 & 57 & 82 & 95.0 & 0.95 \\
\hline 98 & 118 & 177 & 58 & 131 & 142.0 & 1.42 \\
\hline 101.5 & 121 & 179 & & 133 & 144.3 & 1.44 \\
\hline 101.5 & 365 & 425 & & 375 & 388.3 & 3.88 \\
\hline 105 & 380 & 440 & & 380 & 400.0 & 4.00 \\
\hline 105 & 4700 & 4780 & & 4700 & 4726.7 & 47.27 \\
\hline 80 & 4730 & 4793 & & 4735 & 4752.7 & 47.53 \\
\hline 78 & 4737 & 4794 & & 4742 & 4757.7 & 47.58 \\
\hline 38.7 & 4737 & 4794 & & 4742 & 4757.7 & 47.58 \\
\hline 39.2 & 4737 & 4794 & & 4742 & 4757.7 & 47.58 \\
\hline 0 & 4730 & 4750 & & 4710 & 4730.0 & 47.30 \\
\hline 0 & 4685 & 4706 & & 4671 & 4687.3 & 46.87 \\
\hline
\end{tabular}




\section{ANEXO I}

Estaca 03 - Ensaio Rápido - Solo Inund. na Carga de Trabalho - Data: 05/11/92

\begin{tabular}{|c|c|c|c|c|c|c|}
\hline \multirow{2}{*}{$\begin{array}{c}\text { CARGA } \\
(\mathrm{kN})\end{array}$} & \multicolumn{7}{|c|}{ EXTENSOMETROS (x10E-2 mm) } & $\begin{array}{c}\text { DESLOCAM. } \\
(\mathrm{mm})\end{array}$ \\
\hline & 1 & 2 & 3 & 4 & MÉDIA & 0.00 \\
\hline 0 & 0 & & 0 & 0 & 0.0 & 0.00 \\
\hline 7.5 & 0 & & 0 & 0 & 0.0 & 0.07 \\
\hline 15 & 7 & & 7 & 7 & 7.0 & 0.11 \\
\hline 15 & 10 & & 12 & 10 & 10.7 & 0.23 \\
\hline 22.5 & 25 & & 25 & 20 & 23.3 & 0.30 \\
\hline 22.5 & 30 & & 32 & 27 & 29.7 & 0.41 \\
\hline 30 & 40 & & 45 & 37 & 40.7 & 0.49 \\
\hline 30 & 47 & & 53 & 46 & 48.7 & 0.53 \\
\hline 37.5 & 50 & & 60 & 50 & 53.3 & 0.63 \\
\hline 37.5 & 59 & & 71 & 60 & 63.3 & 0.68 \\
\hline 45 & 65 & & 75 & 65 & 68.3 & 0.71 \\
\hline 45 & 67 & & 80 & 67 & 71.3 & 0.76 \\
\hline 52.5 & 72 & & 83 & 72 & 75.7 & 47.67 \\
\hline 52.5 & 4735 & & 4770 & 4795 & 4766.7 & 47.90 \\
\hline 31.4 & 4798 & & 4775 & 4796 & 4789.7 & 47.95 \\
\hline 31.2 & 4804 & & 4778 & 4802 & 4794.7 & 47.95 \\
\hline 15.3 & 4804 & & 4778 & 4802 & 4794.7 & 47.95 \\
\hline 15.5 & 4804 & & 4778 & 4802 & 4794.7 & 47 \\
\hline 0 & 4645 & & 4660 & 4660 & 4655.0 & 46.55 \\
\hline 0 & 4369 & & 4482 & 4368 & 4406.3 & 44.06 \\
\hline
\end{tabular}




\section{ANEXO J}

Estaca 04 - Ensaio Lento - Solo c/ Umidade Natural - Data: 30/03/93

\begin{tabular}{|c|c|c|c|c|c|c|}
\hline \multirow{2}{*}{$\begin{array}{c}\text { CARGA } \\
(\mathrm{kN})\end{array}$} & \multicolumn{7}{|c|}{ EXTENSOMETROS $(\mathrm{x} 10 \mathrm{E}-2 \mathrm{~mm})$} & $\begin{array}{c}\text { DESLOCAM. } \\
(\mathrm{mm})\end{array}$ \\
\hline & 1 & 2 & 3 & 4 & MEDIA & 0.00 \\
\hline 8 & 0 & 0 & 0 & 0 & 0.0 & 0.00 \\
\hline 8 & 0 & 0 & 0 & 0 & 0.0 & 0.01 \\
\hline 18.4 & 3 & 0 & 0 & 0 & 1.0 & 0.02 \\
\hline 18.4 & 4 & 1 & 1 & 0 & 1.7 & 0.02 \\
\hline 28.6 & 6 & 1 & 1 & 0 & 2.3 & 0.06 \\
\hline 38.9 & 9 & 8 & 2 & 1 & 6.0 & 0.06 \\
\hline 38.9 & 9 & 9 & 3 & 1 & 6.3 & 0.08 \\
\hline 49.2 & 9 & 13 & 3 & 3 & 8.3 & 0.09 \\
\hline 49.2 & 10 & 14 & 3 & 4 & 9.3 & 0.11 \\
\hline 59.5 & 10 & 18 & 3 & 5 & 11.0 & 0.13 \\
\hline 59.5 & 10 & 22 & 5 & 6 & 12.7 & 0.16 \\
\hline 69.7 & 12 & 27 & 7 & 8 & 15.7 & 0.25 \\
\hline 69.7 & 23 & 33 & 9 & 20 & 25.3 & 0.25 \\
\hline 80 & 23 & 33 & 9 & 20 & 25.3 & 0.27 \\
\hline 80 & 23 & 36 & 9 & 23 & 27.3 & 0.29 \\
\hline 90.3 & 23 & 40 & 9 & 24 & 29.0 & 0.39 \\
\hline 90.3 & 34 & 50 & 20 & 33 & 39.0 & 0.39 \\
\hline 100.6 & 34 & 51 & & 33 & 39.3 & 0.39 \\
\hline 100.6 & 37 & 67 & & 42 & 48.7 & 0.49 \\
\hline 110.8 & 37 & 75 & & 43 & 51.7 & 0.52 \\
\hline 110.8 & 43 & 85 & & 51 & 59.7 & 0.60 \\
\hline 121.1 & 43 & 93 & & 54 & 63.3 & 0.63 \\
\hline 121.1 & 67 & 115 & & 77 & 86.3 & 0.86 \\
\hline 131.4 & 72 & 122 & & 80 & 91.3 & 0.91 \\
\hline 131.4 & 166 & 247 & & 180 & 197.7 & 1.98 \\
\hline 141.6 & 172 & 252 & & 190 & 204.7 & 2.05 \\
\hline 141.6 & 4880 & 5010 & & 4858 & 4916.0 & 49.16 \\
\hline 107.9 & 4883 & 5026 & & 4863 & 4924.0 & 49.24 \\
\hline 106.6 & 4883 & 5034 & & 4869 & 4928.7 & 49.29 \\
\hline 48.8 & 4883 & 5009 & & 4869 & 4920.3 & 49.20 \\
\hline 49.3 & 4883 & 5006 & & 4869 & 4919.3 & 49.19 \\
\hline 0 & 4860 & 4912 & & 4860 & 4877.3 & 48.77 \\
\hline 0 & 4844 & 4892 & & 4851 & 4862.3 & 48.62 \\
\hline
\end{tabular}




\section{ANEXO K}

Estaca 04 - Ensaio Lento - Solo Inund. na Carga de Trabalho - Data: 31/03/93

\begin{tabular}{|c|c|c|c|c|c|c|}
\hline CARGA & \multicolumn{7}{|c|}{ EXTENSOMETROS (X10E-2 mm) } & MEDIA & DESLOCAM \\
\hline$(\mathrm{kN})$ & 1 & 2 & 3 & 4 & $(\mathrm{~mm})$ & \\
\hline 0 & 0 & 0 & & 0 & 0.0 & 0.00 \\
\hline 10.3 & 0 & 0 & & 0 & 0.0 & 0.00 \\
\hline 20.3 & 6 & 0 & & 6 & 4.0 & 0.04 \\
\hline 20.3 & 7 & 0 & & 8 & 5.0 & 0.05 \\
\hline 30.3 & 15 & 0 & & 16 & 10.3 & 0.10 \\
\hline 30.3 & 16 & 0 & & 20 & 12.0 & 0.12 \\
\hline 40.4 & 26 & 0 & & 27 & 17.7 & 0.18 \\
\hline 40.4 & 26 & 43 & & 33 & 34.0 & 0.34 \\
\hline 50.4 & 26 & 52 & & 37 & 38.3 & 0.38 \\
\hline 50.4 & 26 & 60 & & 41 & 42.3 & 0.42 \\
\hline 60.4 & 48 & 62 & & 52 & 54.0 & 0.54 \\
\hline 60.4 & 48 & 65 & & 54 & 55.7 & 0.56 \\
\hline 70.4 & 48 & 77 & & 56 & 60.3 & 0.60 \\
\hline 70.4 & 4917 & 4874 & & 4828 & 4873.0 & 48.73 \\
\hline 48.2 & 4918 & 4877 & & 4828 & 4874.3 & 48.74 \\
\hline 47.4 & 4920 & 4818 & & 4828 & 4855.3 & 48.55 \\
\hline 32.2 & 4920 & 4818 & & 4828 & 4855.3 & 48.55 \\
\hline 32.2 & 4920 & 4818 & & 4828 & 4855.3 & 48.55 \\
\hline 0 & 4890 & 4850 & & 4828 & 4856.0 & 48.56 \\
\hline 0 & 4800 & 4765 & & 4800 & 4788.3 & 47.88 \\
\hline
\end{tabular}




\section{ANEXO L}

Estaca 01 - Reensaio -Ens. Rápido - Solo Inund. na Carga de Trabalho - Data: 26/07/93

\begin{tabular}{|c|c|c|c|c|c|c|}
\hline \multirow{2}{*}{$\begin{array}{c}\text { CARGA } \\
(\mathrm{kN})\end{array}$} & \multicolumn{5}{|c|}{ EXTENSOMETROS $(\times 10 \mathrm{E}-2 \mathrm{~mm})$} & \multirow{2}{*}{$\begin{array}{l}\text { RECALQUE } \\
(\mathrm{mm})\end{array}$} \\
\hline & 1 & 2 & 3 & 4 & MEDIA & \\
\hline 0 & 0 & 0 & 0 & 0 & 0.0 & 0 \\
\hline 5 & 0 & 0 & 5 & 5 & 2.5 & 0.03 \\
\hline 10 & 0 & 0 & 11 & 12 & 5.8 & 0.06 \\
\hline 10 & 0 & 0 & 14 & 12 & 6.5 & 0.07 \\
\hline 15 & 0 & 0 & 18 & 18 & 9.0 & 0.09 \\
\hline 15 & 0 & 0 & 20 & 19 & 9.8 & 0.10 \\
\hline 20 & 0 & 0 & 26 & 27 & 13.3 & 0.13 \\
\hline 20 & 0 & 3 & 34 & 34 & 17.8 & 0.18 \\
\hline 25 & 8 & 12 & 45 & 46 & 27.8 & 0.28 \\
\hline 25 & 16 & 22 & 60 & 62 & 40.0 & 0.40 \\
\hline 30 & 24 & 31 & 70 & 74 & 49.8 & 0.50 \\
\hline 30 & 38 & 38 & 89 & 96 & 65.3 & 0.65 \\
\hline 35 & 43 & 37 & 101 & 106 & 71.8 & 0.72 \\
\hline 35 & 58 & 73 & 125 & 131 & 96.8 & 0.97 \\
\hline 40 & 62 & 76 & 132 & 141 & 102.8 & 1.03 \\
\hline 40 & 93 & 98 & 159 & 165 & 128.8 & 1.29 \\
\hline 45 & 96 & 104 & 167 & 175 & 135.5 & 1.36 \\
\hline 45 & 112 & 120 & 186 & 195 & 153.3 & 1.53 \\
\hline 50 & 115 & 125 & 192 & 204 & 159.0 & 1.59 \\
\hline 50 & 129 & 141 & 218 & 227 & 178.8 & 1.79 \\
\hline 60 & 290 & 309 & 423 & 450 & 368.0 & 3.68 \\
\hline 60 & 2110 & 2150 & 2270 & 2300 & 2207.5 & 22.08 \\
\hline 65 & 2420 & 2500 & 2520 & 2550 & 2497.5 & 24.98 \\
\hline 65 & 4750 & 4790 & 4900 & 4930 & 4842.5 & 48.43 \\
\hline 59.3 & 4755 & 4801 & 4928 & 4935 & 4854.8 & 48.55 \\
\hline 56 & 4765 & 4809 & 4934 & 4952 & 4865.0 & 48.65 \\
\hline 32.2 & 4765 & 4806 & 4932 & 4933 & 4859.0 & 48.59 \\
\hline 32.7 & 4765 & 4805 & 4930 & 4930 & 4857.5 & 48.58 \\
\hline 0 & 4680 & 4770 & 4840 & 4810 & 4775.0 & 47.75 \\
\hline 0 & 4590 & 4647 & 4733 & 4706 & 4669.0 & 46.69 \\
\hline
\end{tabular}


ANEXO M

Estaca Strauss - Ensaio Rápido - Solo Inund. na Carga de Trabalho - Data: 17/08/93

\begin{tabular}{|c|c|c|c|c|c|c|}
\hline \multirow{2}{*}{$\begin{array}{c}\text { CARGA } \\
(\mathrm{kN})\end{array}$} & 1 & 2 & 3 & 4 & MEDIA & $\begin{array}{c}\text { DESLOCAM. } \\
(\mathrm{mm})\end{array}$ \\
\hline & 0 & 0 & 0 & & 0.0 & 0.00 \\
\hline 20 & 0 & 1 & 3 & & 1.3 & 0.01 \\
\hline 40 & 0 & 4 & 4 & & 2.7 & 0.03 \\
\hline 40 & 0 & 5 & 5 & & 3.3 & 0.03 \\
\hline 60 & 3 & 10 & 9 & & 7.3 & 0.07 \\
\hline 60 & 5 & 12 & 10 & & 9.0 & 0.09 \\
\hline 80 & 7 & 15 & 14 & & 12.0 & 0.12 \\
\hline 80 & 11 & 18 & 17 & & 15.3 & 0.15 \\
\hline 100 & 13 & 21 & 21 & & 18.3 & 0.18 \\
\hline 100 & 18 & 26 & 25 & & 23.0 & 0.23 \\
\hline 120 & 21 & 30 & 29 & & 26.7 & 0.27 \\
\hline 120 & 28 & 38 & 38 & & 34.7 & 0.35 \\
\hline 140 & 32 & 43 & 45 & & 40.0 & 0.40 \\
\hline 140 & 43 & 53 & 54 & & 50.0 & 0.50 \\
\hline 160 & 45 & 60 & 65 & & 56.7 & 0.57 \\
\hline 160 & 58 & 70 & 80 & & 69.3 & 0.69 \\
\hline 180 & 61 & 77 & 85 & & 74.3 & 0.74 \\
\hline 180 & 91 & 100 & 105 & & 98.7 & 0.99 \\
\hline 200 & 96 & 108 & 115 & & 106.3 & 1.06 \\
\hline 200 & 175 & 172 & 190 & & 179.0 & 1.79 \\
\hline 220 & 179 & 179 & 198 & & 185.3 & 1.85 \\
\hline 220 & 183 & 184 & 208 & & 191.7 & 1.92 \\
\hline 240 & 191 & 192 & 216 & & 199.7 & 2.00 \\
\hline 240 & 210 & 211 & 236 & & 219.0 & 2.19 \\
\hline 260 & 219 & 219 & 245 & & 227.7 & 2.28 \\
\hline 260 & 247 & 247 & 280 & & 258.0 & 2.58 \\
\hline 280 & 262 & 264 & 289 & & 271.7 & 2.72 \\
\hline 280 & 295 & 295 & 324 & & 304.7 & 3.05 \\
\hline 300 & 304 & 306 & 333 & & 314.3 & 3.14 \\
\hline 300 & 433 & 437 & 468 & & 446.0 & 4.46 \\
\hline 320 & 472 & 485 & 507 & & 488.0 & 4.88 \\
\hline 320 & 4671 & 4754 & 4658 & & 4694.3 & 46.94 \\
\hline 304.9 & 4712 & 4882 & 4804 & & 4799.3 & 47.99 \\
\hline 280.4 & 4793 & 4943 & 4889 & & 4875.0 & 48.75 \\
\hline 116.4 & 4739 & 4849 & 4882 & & 4823.3 & 48.23 \\
\hline 118.9 & 4735 & 4842 & 4871 & & 4816.0 & 48.16 \\
\hline 0 & 4620 & 4680 & 4787 & & 4695.7 & 46.96 \\
\hline 0 & 4509 & 4511 & 4629 & & 4549.7 & 45.50 \\
\hline
\end{tabular}




\section{ANEXO N}

Estaca 02 - Reensaio - Ens. Lento - Solo Natural - Data: 28/10/93

\begin{tabular}{|c|c|c|c|c|c|c|}
\hline CARGA & \multicolumn{7}{|c|}{ EXTENSOMETROS $(\times 10 E-2 \mathrm{~mm})$} & DESLOCAM \\
\hline$(\mathrm{kN})$ & 1 & 2 & 3 & 4 & MEEDIA & $(\mathrm{mm})$ \\
\hline & & & & & & \\
\hline 0 & 0 & 0 & 0 & 0 & 0.0 & 0.00 \\
\hline 7 & 0 & 0 & 0 & 0 & 0.0 & 0.00 \\
\hline 14 & 0 & 0 & 0 & 0 & 0.0 & 0.00 \\
\hline 21 & 0 & 5 & 8 & 4 & 4.3 & 0.04 \\
\hline 21 & 0 & 10 & 14 & 11 & 8.8 & 0.09 \\
\hline 28 & 0 & 18 & 26 & 22 & 16.5 & 0.17 \\
\hline 28 & 13 & 34 & 45 & 41 & 33.3 & 0.33 \\
\hline 35 & 23 & 48 & 59 & 58 & 47.0 & 0.47 \\
\hline 35 & 50 & 53 & 87 & 88 & 69.5 & 0.70 \\
\hline 42 & 60 & 80 & 100 & 103 & 85.8 & 0.86 \\
\hline 42 & 90 & 117 & 131 & 136 & 118.5 & 1.19 \\
\hline 49 & 95 & 123 & 138 & 145 & 125.3 & 1.25 \\
\hline 49 & 132 & 145 & 176 & 188 & 160.3 & 1.60 \\
\hline 56 & 134 & 144 & 182 & 194 & 163.5 & 1.64 \\
\hline 56 & 166 & 191 & 225 & 230 & 203.0 & 2.03 \\
\hline 63 & 170 & 200 & 230 & 235 & 208.8 & 2.09 \\
\hline 63 & 200 & 235 & 274 & 280 & 247.3 & 2.47 \\
\hline 70 & 220 & 245 & 282 & 290 & 259.3 & 2.59 \\
\hline 70 & 275 & 316 & 352 & 357 & 325.0 & 3.25 \\
\hline 77 & 277 & 320 & 358 & 362 & 329.3 & 3.29 \\
\hline 77 & 4550 & 4510 & 4520 & 4730 & 4577.5 & 45.78 \\
\hline 51.64 & 4800 & 4900 & 4920 & 4940 & 4890.0 & 48.90 \\
\hline 51.56 & 4825 & 4910 & 4947 & 4973 & 4913.8 & 49.14 \\
\hline 50.9 & 4825 & 4914 & 4928 & 4954 & 4905.3 & 49.05 \\
\hline 50.91 & 4825 & 4914 & 4928 & 4954 & 4905.3 & 49.05 \\
\hline 0 & 4800 & 4840 & 4870 & 4890 & 4850.0 & 48.50 \\
\hline 0 & 4749 & 4810 & 4825 & 4845 & 4807.3 & 48.07 \\
\hline
\end{tabular}


ANEXO O

Estaca 02 - Apiloada - Reensaio - Ens. Rápido - Solo Natural - Data: 29/10/93

\begin{tabular}{|c|c|c|c|c|c|c|}
\hline CARGA & \multicolumn{7}{|c|}{ EXTENSOMETROS $(x 10$ E $-2 \mathrm{~mm})$} & DESLOCAM \\
\hline$(\mathrm{kN})$ & 1 & 2 & 3 & 4 & MEDIA & $(\mathrm{mm})$ \\
\hline 0 & 0 & & 0 & 0 & 0.0 & 0 \\
\hline 3.5 & 0 & & 0 & 0 & 0.0 & 0 \\
\hline 7 & 0 & & 0 & 0 & 0.0 & 0 \\
\hline 10.5 & 0 & & 1 & 4 & 1.7 & 0.02 \\
\hline 14 & 0 & & 5 & 7 & 4.0 & 0.04 \\
\hline 17.5 & 1 & & 8 & 10 & 6.3 & 0.06 \\
\hline 17.5 & 3 & & 10 & 12 & 8.3 & 0.08 \\
\hline 21 & 4 & & 14 & 16 & 11.3 & 0.11 \\
\hline 21 & 5 & & 15 & 19 & 13.0 & 0.13 \\
\hline 24.5 & 7 & & 20 & 24 & 17.0 & 0.17 \\
\hline 24.5 & 8 & & 24 & 27 & 19.7 & 0.20 \\
\hline 28 & 11 & & 28 & 32 & 23.7 & 0.24 \\
\hline 28 & 13 & & 32 & 36 & 27.0 & 0.27 \\
\hline 31.5 & 15 & & 36 & 41 & 30.7 & 0.31 \\
\hline 31.5 & 16 & & 40 & 46 & 34.0 & 0.34 \\
\hline 35 & 20 & & 44 & 52 & 38.7 & 0.39 \\
\hline 35 & 22 & & 46 & 55 & 41.0 & 0.41 \\
\hline 38.5 & 24 & & 50 & 59 & 44.3 & 0.44 \\
\hline 38.5 & 25 & & 54 & 64 & 47.7 & 0.48 \\
\hline 42 & 25 & & 57 & 68 & 50.0 & 0.50 \\
\hline 42 & 40 & & 59 & 72 & 57.0 & 0.57 \\
\hline 45.5 & 42 & & 83 & 87 & 70.7 & 0.71 \\
\hline 45.5 & 47 & & 88 & 93 & 76.0 & 0.76 \\
\hline 49 & 69 & & 90 & 95 & 84.7 & 0.85 \\
\hline 52.5 & 70 & & 93 & 98 & 87.0 & 0.87 \\
\hline 56 & 75 & & 100 & 104 & 93.0 & 0.93 \\
\hline 59.5 & 81 & & 107 & 110 & 99.3 & 0.99 \\
\hline 63 & 87 & & 115 & 120 & 107.3 & 1.07 \\
\hline 63 & 89 & & 119 & 127 & 111.7 & 1.12 \\
\hline 66.5 & 98 & & 128 & 132 & 119.3 & 1.19 \\
\hline 66.5 & 98 & & 131 & 138 & 122.3 & 1.22 \\
\hline 70 & 103 & & 135 & 141 & 126.3 & 1.26 \\
\hline 70 & 104 & & 137 & 145 & 128.7 & 1.29 \\
\hline 73.5 & 110 & & 145 & 152 & 135.7 & 1.36 \\
\hline 73.5 & 110 & & 163 & 171 & 148.0 & 1.48 \\
\hline 77 & 128 & & 171 & 178 & 159.0 & 1.59 \\
\hline 77 & 151 & & 199 & 209 & 186.3 & 1.86 \\
\hline 80.5 & 154 & & 204 & 215 & 191.0 & 1.91 \\
\hline 80.5 & 250 & & 310 & 325 & 295.0 & 2.95 \\
\hline 84 & 320 & & 410 & 430 & 386.7 & 3.87 \\
\hline 84 & 4870 & & 4830 & 4865 & 4855.0 & 48.55 \\
\hline 51.7 & 4893 & & 4845 & 4874 & 4870.7 & 48.71 \\
\hline 51.6 & 4899 & & 4851 & 4881 & 4877.0 & 48.77 \\
\hline 50.8 & 4898 & & 4840 & 4860 & 4866.0 & 48.66 \\
\hline 50.9 & 4898 & & 4838 & 4858 & 4864.7 & 48.65 \\
\hline 0 & 4880 & & 4790 & 4800 & 4823.3 & 48.23 \\
\hline 0 & 4834 & & 4738 & 4760 & 4777.3 & 47.77 \\
\hline & & & & & & \\
\hline
\end{tabular}




\section{REFERÊNCIAS BIBLIOGRÁFICAS}

ABNT - Associação Brasileira de Normas Técnicas (1991): Estacas -prova de carga estática - MB 3472.

ADAMS, J.I. \& RADHAKRISHNA, H.S. (1971) Uplift resistance of augered footings in fissured clay. Canadian Geotechnical Journal, 8(3): p.452-462.

AGNELLI, N. (1992). Estudo da colapsibilidade do solo de Bauru através de provas de carga diretas. São Carlos, 172 p. (Mestrado - Escola de Engenharia de São Carlos - USP).

ALWAIL, T.A.; HO, C.L. \& FRAGASZY, R.J. (1992) Collapse mechanisms of low cohesion compacted soils. Bulletin of the Association of Engineering Geologists, Vol. 29, n.4, p.345-353.

ARAGÃO, C.J. \& MELO, A.C. (1982) Fundações rasas em solo colapsivel: um caso no semi-árido de Pernambuco. In: CONGRESSO BRASILEIRO DE MECÂNICA DOS SOLOS E ENGENHARIA DE FUNDAÇÕES, 7., Olinda, Recife, 1982, (1): 19-40.

ARUTYUNOV, I.S.; BAGDASAROV, Y.A.; KRUTOV, V.I.; KLEPIKOV, S.N; TREGUB, Y.S; GUPALENKO, V.I. \& KOVAL, I.P. (1983) Cast-in-place piles in compacted type II collapsibility loess soil (for discussion). Soil Mechanics and Foundation Engineering, v.20, n.1, p.13-19.

ASHCAR, R. LAUREANO, C.A \& KIRCHNER, C.A.R. (1985) Tipos, critérios e comportamento de fundações de torres de linhas de transmissão. In: SEMINÁRIO DE ENGENHARIA DE FUNDAÇÕES ESPECIAIS, 1., São Paulo, 1985, ABMS, (1): 237-256.

AZEVEDO, N. (1991) Essai de chargement de pieux injectés dans un sol résiduel. Fondations Profondes. Acte du colloque organisé par l'Ecole Nationale des Ponts et Chaussées, Paris, p. 345-352. 
BALLA, A. (1961) The resistance to breaking out of mushroom foundations for pylons. In: INTERNATIONAL CONFERENCE ON SOIL MECHANICS AND FOUNDATIONS ENGINEERING, 5, Paris, France. Anais. v.1, p.569-576.

BARATA, F.E.; PACHECO, M.P.; DANZIGER, F.A.B. (1978) Uplift tests on drilled piers and footings built in residual soil. In: CONGRESSO BRASILEIRO DE MECÂNICA DOS SOLOS E ENGENHARIA DE FUNDAÇÕES, 6., Rio de Janeiro, 1978. Anais. Rio de Janeiro, p.1-37.

BARATA, F.E.; PACHECO, M.P.; DANZIGER, F.A.B.; PEREIRA PINTO, C. (1979) Foundations under pulling loads in residual soil: analysis and application of the results of load tests. In: PANAMERICAN CONFERENCE ON SOIL MECHANICS AND FOUNDATION ENGINEERING, 6., Lima, 1979. Proceedings. Lima, p. 165-176.

BENVENUTO, C. (1982) Uma avaliação teórico-experimental do comportamento de alguns solos colapsíveis, São Paulo, 158p. (Mestrado - Escola Politécnica da Universidade de São Paulo).

BEREZANTZEV, V.G.; KHRISTOFOROV, V. \& GOLUBKOV, V. (1961) Load bearing capacity and deformation of piled foundation. In: INTERNATIONAL CONFERENCE ON SOIL MECHANICS AND FOUNDATION ENGINEERING, 5., Paris, ,France, 1961. Proceedings. (2): 11-15

BIAREZ, J. \& BARRAUD, Y. (1968) Adaptation des foundations de phlones au terrain par les méthodes de la mécanique de sds. In: CONFERENCE INTERNATIONALE DES GRANDS RESEAUX ELECTRQUES, Paris. Compte Rendu (Repport 22-06).

BJERRUM, L. (1973) Problems of soil mechanics and construction on soft clays and structurally unstable soils (collapsible, expansive and others). In: INTERNATIONAL CONFERENCE ON SOIL MECHANICS AND FOUNDATION ENGINEERING, Moscow, 1973. Proceedings. Moscow, (3): p.111-160.

BOWLES, J.E. (1988) Foundation analysis and design. 4. ed., Singapore, Mc GrawHill Book Co. 
BROMS, B.B. (1963). Allowable bearing capacity of initially bent piles. Journal of Soil Mechanics and Foundation Division, ASCE, (89) SM5: 73-90.

CARVALHO, D. (1991) Análise de cargas últimas à tração de estacas escavadas, instrumentadas, em campo experimental de São Carlos, SP. São Carlos, 204p. (Doutourado - Escola de Engenharia de São Carlos-USP).

CARVALHO, D. \& ALBUQUERQUE, P.J.R. (1994). Comportamento de estacas de pequeno porte à tração, em solos colapsíveis. In: SIMPÓSIO SOBRE SOLOS NÃO SATURADOS, 2., Recife. Anais, ABMS, p. 237-242.

CARVALHO, D.; MANTILLA, J.N.R.; ALBIERO, J.H. \& CINTRA, J.C.A. (1991) Provas de carga à tração e à compressão em estacas instrumentadas do tipo raiz. In: SEMINÁRIO DE ENGENHARIA DE FUNDAÇÕES ESPECIAIS, 2., 1991, São Paulo. Anais. São Paulo, ABMS, (1): p.79-87.

CARVALHO, D. \& SOUZA, A. (1990) Análise do efeito do umedecimento do solo em fundações rasas e profundas em solos porosos. In: CONGRESSO BRASILEIRO DE MECÂNICA DOS SOLOS E ENGENHARIA DE FUNDAÇÕES, 6., 1990, Salvador. São Paulo, ABMS, (2): p.107-114.

CHATTOPADHYAY, B.C. \& PISE, P.J. (1986) Uplift capacity of piles in sand. Journal of Geotechnical Engineering, ASCE, 112(9): p.888-904.

CINTRA, J.C.A \& NOGUEIRA, J.B. (1985) Shallow foundations on collapsible soils. In: INTERNATIONAL IAEG CONGRESS, 5., Buenos Aires. Anais. Rotterdan, Balkema, 1986. p.673-675.

CINTRA, J.C.A; CARVALHO, D.; GIACHETTI, H.L.; BORTOLUCCI, A.A. \& ALBIERO, J.H. (1991). Campo experimental de fundações de São Carlos. In: SEMINÁRIO DE ENGENHARIA DE FUNDAÇÕES ESPECIAIS, 2., 1991, São Paulo. Anais. São Paulo, ABMS, (1): p.96-105.

CINTRA, T. (1993) Estudo comparativo de provas de carga direta. Relatório de Iniciação Científica. São Carlos, SGS/EESC/USP.

COSTA, F.V. (1956) Estacas para fundações, 2. ed., São Paulo, Ed. Horácio Lane. 
DANZIGER, F.A.B. (1983) Capacidade de carga de fundações submetidas a esforços verticais de tração. Rio de Janeiro, 331p. (Mestrado - Universidade Federal do Rio de Janeiro).

DANZIGER, F.A.B. (1984) Discussões. In: SEMINÁRIO NACIONAL DE PRODUÇÃO E TRANSMISSÃO DE ENERGIA ELÉTRICA, 7., Brasilia, 1984. Brasilia, (1): p.412-417.

DANZIGER, F.A.B. (1985) Tema V: Fundações de torres de linhas de transmissão. In: SÉMINÁRIO DE ENGENHARIA DE FUNDAÇÕES ESPECIAIS, 1., São Paulo, 1985. Debates. São Paulo, ABMS, (3): p.139-163.

DANZIGER, F.A.B. \& PEREIRA PINTO, C. (1979a) Alguns critérios para dimensionamento de fundações sujeitas a esforços de tração. In: SEMINÁRIO NACIONAL DE PRODUÇÃO E TRANSMISSÃO DE ENERGIA ELÉTRICA, 5., Recife, 1979. Anais. Recife.

DANZIGER, F.A.B. \& PEREIRA PINTO, C. (1979b) Análise comparativa de métodos para o dimensionamento de fundações a partir dos resultados de provas de carga realizadas na LT $500 \mathrm{kV}$ Adrianópolis-Grajau. In: SEMINÁRIO NACIONAL DE PRODUÇÃO E TRANSMISSÃO DE ENERGIA ELÉTRICA, 5., Recife, 1979. Anais. Recife.

DAS, B.J. (1983) A procedure for estimation of uplift capacity of rough piles. Soils and Foundations, 23(3): p. 122-126.

DAS, B.J.; SEELEY, D. \& PFEIFLE, M. (1977). Pullout resistance of rough rigid piles in granular soil. Soils and Foundations, 17 (3): 72-77.

DAS, B.J. \& ROZENDAL, D. (1983) Ultimate uplift capacity of piles in sand. Transportaion Research Record, p.40-45.

De NICOLA, A. \& RANDOLPH, M.F. (1993) Tensile and compressive shaft capacity of pile in sand. Journal of Geotechnical Engineering, ASCE, v.119, n. 12, p. 1952-1973. 
DÉCOURT, L. (1991). Throughts concerning the interpretation of sucessive load tests on the same pile. In: PANAMERICAN CONFERENCE ON SOIL MECHANICS AND FOUNDATION ENGINEERING, 4., Santiago, Chile. (1): 585-597.

DUDLEY, J.H. (1970). Review of collapsing soils. Journal of the Soil Mechanics and Foundation Division, ASCE. SM 3, (96): p.925-947.

EL-EHWANY, M. \& HOUSTON, S.L. (1990) Settlement and moisture movement in collapsible soils. Journal of Geotechnical Engineering, ASCE, v.116, n.10, p.1521-1535.

FELLENIUS, B.H. (1975). Test load of piles and new proof testing procedure. Journal of Geotechnical Engineering Division, (101), GT9: 855-869.

FERREIRA, A.C. \& LOPES, F.R. (1985) Contribuição ao estudo do efeito do tempo de carregamento no comportamento de estacas de prova. In: SEMINÁRIO DE ENGENHARIA DE FUNDAÇÕES ESPECIAIS, 1., São Paulo, 1985. São Paulo, ABMS, (2): p. 185-192.

GHALY, A. \& HANNA, A. (1991) Performance of piles with enlarged bases subject to uplift forces. Canadian Geotechnical Journal, v.28, n.5, p.760-762.

GRIGORYAN, A.A. \& CHINENKOV, Y.A. (1994). Prediction of collapse of loess soil thickness. In: INTERNATIONAL CONFERENCE ON SOIL MECHANICS AND FOUNDATION ENGINEERING, 13., New Delhi, India. (1): 107-110.

GRIGORYAN, A.A. \& CHINENKOV, Y.A. (1990) Bearing capacity and settlement of bored piles with enlarged bases in collapsible soils. In: EUROPEAN CONFERENCE ON SOIL MECHANICS AND FOUNDATIONS ENGINEERING, 19, Budapest/Hungary, Anais. p.203-210.

GRIGORYAN, A.A. \& CHAKYVAZDE (1986). Effect of undereaming on bearing capacity of bored pile. Soil Mechanics and Foundations Engineering, 23 (6): p. 231. 
GRIGORYAN, A.A. \& CHINENKOV, Y.A. (1991) Experience with construction on long underreamed piles in collapsible soils. Soil Mechanics and Foundation Engineering, 27(4): p.135-141.

GRIGORYAN, A.A. \& CHINENKOV, Y.A. (1980). Bored/cast-in-place piles employing soil compactacion of hole bottom, for the "Atommash " plant. In: Soil Mechanics and Foundation Engineering, Vol. 17. n. 6. p.227.

GRIGORYAN, A.A. \& YUSHUBE, S.V. (1986) Interection of cast-in-place piles with soil under type II collapsibility conditions. Soil Mechanics and Foundations Engineering, v.23, n.2, p.51-57.

GRIGORYAN, A.A. \& KHABIBULLIN, I.I. (1980). Experimental investigation of the distribuition of stress in large bored situ-cast piles. In: Soil Mechanics and Foundation Engineering. Vol. 17. n. 3. p.102-106.

HANNA, A. \& GHALY, A. (1992) Effects of $\mathrm{K}_{\mathrm{O}}$ and overconsolidation on uplift capacity. Journal of Geotechnical Engineering, ASCE, v.118, n.9, p.1449-1469.

HOLTZ, W.G. \& GIBBS, H.J. (1953) Field tests to determine the behavior of piles in loess. In: INTERNATIONAL CONFERENCE ON SOIL MECHANICS AND FOUNDATION ENGINEERING, 3., Zurich, (2): 51-56.

IL'ICHEV, V.A.; BAGDASAROV, Y.A \& MAMONOV, V.M. Determination of pile settlement under type II collapsibility soil condition. Soil Mechanics and Foundation Engineering, (5): 14-18.

IRELAND, H.O. (1957) Pulling tests on piles in sand. In: INTERNATIONAL CONFERENCE ON SOIL MECHANICS AND FOUNDATION ENGINEERING, 4., London, 1957. Proceedings. London, (2): p.43-54.

ISMAEL, N.F. \& KLYM, T.W. (1979) Uplift and bearing capacity of short piers in sand. Journal of Geotechnical Engineering, ASCE, 105(5): p.579-593.

JÁKY, J. (1948). Pressure in silos. In: INTERNATIONAL CONFERENCE ON SOIL MECHANICS AND FOUNDATION ENGINEERING, 2., Proceedings, (2): p.103-107. 
KÉZDI, Á. (1975). Pile foundations. In: Foundation Engineering Handbook. Winterkorn, H. \& Fang, H.Y., Van Nostrand Reinhold, New York.

KRUTOV, V.I.; BULGAKOV, V.I. \& KOROTKOVA, Y. (1980). Effect the degree of increase of water content on the relative slumping and consolidation of loess soil. Soil Mechanics and Foundation Engineering, ASCE, 17 (1): 26-31

KILLER, J. (1953) Fondations économiques des pylones de lignes aerines. In: INTERNATIONAL CONFERENCE ON SOIL MECHANICS AND FOUNDATIONS ENGINEERING, 3., Zurich, 1953. Proceedings. Zurich, (3): p. 265-276.

KULHAWY, F.H. (1985) Drained uplift capacity of drilled shafts. In: INTERNATIONAL CONFERENCE ON SOIL MECHANICS AND FOUNDATION ENGINEERING, 11., San Francisco, 1985. Proceedings. San Francisco, (3): p. 1549-1552.

KULHAWY, F.H \& PETERSON, M.S. (1979) Behavior of sand-concrete interfaces, In: CONGRESSO PANAMERICANO DE MECÁNICA DE SUELOS Y INGENIERIA DE CIMENTACIONES, 6., Lima, Peru, 1979, (2): 225-236

LEHANE, B.M.; JARDINE, R.J.; BOND, A.J. \& FRANK, R. (1993) Mechanisms of shaft friction in sand from instrumented piles tests. Journal of Geotechnical Engineering, $A S C E$, v.119, n.1, p.19-35.

LOBO, A.S. (1991). Colapsibilidade do solo de Bauru e sua influência em estacas de pequeno porte. São Carlos, 216 p. (Doutouramento, Escola de Engenharia de São Carlos -USP).

LOBO, A.S.; ALBIERO, J.H.; \& FERREIRA, C.V. (1991a). Influência da inundação na carga última de estacas de pequeno porte. In: SEMINÁRIO DE ENGENHARIA DE FUNDAÇÕES ESPECIAIS, 2., São Paulo, 1991. São Paulo, ABMS, (2): p.217-226.

MANSUR, C.I. \& KAUFMAN, R.I. (1958). Pile tests, low-sill structure, Old River, Lousiania. Translation, ASCE (123): 715-743. 
MANTILLA, J.N. (1992). Comportamento de estacas escavadas, instrumentadas à compressão. São Carlos, 251 p. (Doutouramento, Escola de Engenharia de São Carlos - USP).

MARTIN, D. (1973) Calcul des pieux et foundations à dalle des pylones de transport d'energie électrique. Etude théorique et resultats d'essais en laboratorie et in situ. Annales de L'Institut Technique du Batiment et des Travanx Publies, (307-308): p.105-130, juillet-aout.

MATOS, L.F.S. (1989). Pesquisa experimental da resistência ao arrancamento de estacas escavadas de pequeno diâmetro, num solo parcialmente saturado. Dissertação de Mestrado, CPGEC, UFRGS, 131 p.

MATOS, L.F.S. \& MILITITSKY, J. (1990) Resistência ao arrancamento de estacas em solos parcialmente saturados. In: CONGRESSO BRASILEIRO DE MECÂNICA DOS SOLOS E ENGENHARIA DE FUNDAÇÕES, 9., Salvador, 1990. Anais. São Paulo, ABMS, (2) p.523-534.

MEDEIROS, W.B. (1985). Estudo da fundação de uma linha de transmissão. In: SEMINÁRIO DE ENGENHARIA DE FUNDAÇÕES ESPECIAIS, 2., São Paulo, 1985. São Paulo, ABMS, (2): p.73-102.

MELLIOS, G. (1985) Provas de carga em solos porosos. In: SEMINÁRIO DE ENGENHARIA DE FUNDAÇÕES ESPECIAIS, 1., São Paulo, 1985. São Paulo, ABMS, (2): p.73-102.

MELO, C.E. (1982a) Assessment of methods to predict the uplift capacity of a single pile. In: CONGRESSO BRASILEIRO DE MECÂNICA DOS SOLOS E ENGENHARIA DE FUNDAÇÕES, 7., Olinda. Anais. São Paulo, ABMS, 1982. v.3, p.34-52.

MELO, C.E. (1982b) A method to predict the response of a single pile under uplift loading in clay. In: CONGRESSO BRASILEIRO DE MECÂNICA DOS SOLOS E ENGENHARIA DE FUNDAÇÕES, 7., Olinda. Anais. São Paulo, ABMS, 1982. (2): 53-68. 
MEYERHOF, G.G. (1951) The ultimate bearing capacity of foundations. Geótechinique, (2): p.301-332.

MEYERHOF, G.G. (1973a) The uplift capacity of foundations under oblique loads. Canadian Geotechnical Journal, 10(1): p.64-70.

MEYERHOF, G.G. (1973b) Uplift resistance of inclined anchors and piles. In: INTERNATIONAL CONFERENCE ON SOIL MECHANICS AND FOUNDATIONS ENGINEERING, 8., Moscow, 1973. Proceedings. Moscow, (2): p. 167-172.

MEYERHOF, G.G. (1976) Bearing capacity and settlement of pile foundations. Journal of Geotechnical Engineering, ASCE, 102(3): p.195-228.

MEYERHOF, G.G. \& ADAMS, J.I. (1968) The ultimate uplift capacity of foundations. Canadian Geotechnical Journal, 10(1): p.64-70.

MONTEIRO, L.B. (1985) Alguns aspectos da capacidade de carga de solos colapsiveis. In: SEMINÁRIO DE ENGENHARIA DE FUNDAÇÕES ESPECIAIS, 1., 1985, São Paulo. São Paulo, ABMS, (2) p. 193-202.

NADEO, J.R. \& VIDELA, E.P. (1975a) Comportamiento de pilotes en suelos colapsibles. In: CONGRESSO PANAMERICANO DE MECÁNICA DE SUELOS Y INGENIERIA DE FUNDACIONES, 5., 1975, Buenos Aires, (5): p.303-319.

NADEO, J.R. \& VIDELA, E.P. (1975b) El fenomeno de la humectacion in situ de suelos colapsibles. In: CONGRESSO PANAMERICANO DE MECÁNICA DE SUELOS Y INGENIERIA DE FUNDACIONES, 5., 1975, Buenos Aires, (5): p. $320-326$.

NÁPOLES NETO, A.D.F. (1958). Ensaios de carregamento e arrancamento de uma estaca metálica. In: CONGRESSO BRASILEIRO DE MECÂNICA DOS SOLOS E ENGENHARIA DE FUNDAÇÕES, 2., Recife e Campina Grande. 1958. 
NUÑES, E. (1975). Suelos especiales: colapsibles, expansivos, preconsolidados por desecation. In: CONGRESSO PANAMERICANO DE MECÁNICA DE SUELOS Y INGENIERIA DE FUNDACIONES, 5., Buenos Aires, v.4. p.4373.

ORLANDO, C. (1985) Fundações submetidas a esforços verticais axiais de tração. Análise de provas de carga de tubulões em areias porosas. São Paulo, 235p. (Mestrado - Escola Politécnica da Universidade de São Paulo).

PALADINO, L. (1972) Fundações para torres de linhas de transmissão. In: SEMINÁRIO NACIONAL DE PRODUÇÃO E TRANSMISSÃO DE ENERGIA ELÉTRICA, São Paulo, 1972. Anais. vol. 3.

PALADINO, L. (1975) Fundações para torres de linhas de transmissão. In: CONGRESSO PANAMERICANO DE MECÁNICA DE SUELOS Y INGINIERIA DE FUNDACIONES, 5, Buenos Aires, 1975. Anais. Buenos Aires, Sociedad Argentina de Mecánica de Suelos y Fundaciones, (1):p.437-449.

PALADINO, L. (1985) Fundações de torres de linhas de transmissão. In: SEMINÁRIO DE ENGENHARIA DE FUNDAÇÕES ESPECIAIS, 1., São Paulo, 1985. (2): p.227-236.

POTYONDY, J.G. (1961) Skin friction between various soils and construction materials. Geótechnique, 11(4): p.339-353.

POULOS, H.G. \& DAVIS, E.H. (1980) Pile foundation analysis and design. New York, Wiley \& Sons.

PRAKASH, S. \& SHARMA, H. (1990). Pile foundations in engineering practice. John Wiley \& Sons, New York.

RADHAKRISHNA, H.S. \& ADAMS, J.I. (1973) Long term uplift capacity of augered footings in fissured clay. Canadian Geotechnical Journal, 10(4): p.647652.

RAO, K.S. \& VENKATESH, K.H. (1985) Uplift behavior of short piles in uniform sand. Soil and Foundations, v.25, n.4, p.01-07. 
REESE, L.C.; HUDSON, W.R. \& VIJAYVERGIYA, V.N. (1969) An investigation of the interaction between bored piles and soil. In: INTERNATIONAL CONFERENCE ON SOIL MECHANICS AND FOUNDATIONS ENGINEERING, 7., Mexico City. Anais, v.2, p.211-215.

REGINATTO, A.R. \& FERRERO, J.C. (1973) Collapse potential of soils and soilwater chemistry. In: INTERNATIONAL CONFERENCE ON SOIL MECHANICS AND ENGINEERING FOUNDATIONS, 8., Moscow, 1973, (2): p.177-183.

REZNIK, Y.M. (1993) Plate-load tests of collapsible soils. Journal of Geotechnical Engineering, ASCE, v.119, n.3, p.608-357.

SACILOTTO, A.C. (1992) Comportamento de estacas escavadas instrumentadas, submetidas a provas de carga lentas e rápidas. São Carlos, 165 p. (Mestrado Escola de Engenharia de São Carlos- USP).

SILVA, J.C.B. (1990) Análise dos resultados de provas de carga em estacas de pequeno diâmetro em solo colapsível. In: CONGRESSO BRASILEIRO DE MECÂNICA DOS SOLOS E ENGENHARIA DE FUNDAÇÕES, 6., 1990, Salvador, Anais. São Paulo, ABMS (2): p. 125-131.

SILVEIRA, A. (1957). Contribuição ao estudo dos problemas de fundação para pequenas construções em São Carlos. EESC-USP, São Carlos, SP.

SILVEIRA, A. \& SOUTO, E.B.S. (1963). Low cost shallow foundations. In: CONGRESSO PANAMERICANO DE MECÁNICA DE SUELOS Y INGINIERIA DE FUNDACIONES, 2., São Paulo, 1963. Proceedings. São Paulo, ABMS, (1):p.327-335.

SOWA, V.A. (1970) Pulling capacity of concrete cast-in-situ bored piles. Canadian Geotechnical Journal, v.7, n.4, p.482-494.

SOWERS, G.B. \& SOWERS, G.F. (1972) Introducción a la mecánica de suelos y cimentaciones. 1. ed., Mexico, Editorial Limusa. 
TEIXEIRA, C.Z. (1993) Comportamento de estacas escavadas em solos colapsiveis. São Carlos, 157p. (Mestrado - Escola de Engenharia de São Carlos-USP).

TERZAGHI, K. \& PECK, R.B. (1973) Mecánica de suelos en la ingenieria practica. 2. ed., Buenos Aires, El Ateneo.

TOGROL, E. (1973) Bearing capacity by load tests. In: INTERNATIONAL CONFERENCE ON SOIL MECHANICS AND FOUNDATIONS ENGINEERING, 8., Moscow, 1973, v.1, p.231-236.

TOMLISON, M.J. (1957) The adhesion of piles driven in clay soils. In: INTERNATIONAL CONFERENCE ON SOIL MECHANICS AND FOUNDATIONS ENGINEERING, 5., London. v.2, p.66-71.

TRAN-VO-NHIEM. (1971) Ultimate capacity of anchor piles. BUDAPEST CONFERENCE ON SOIL MECHANICS AND FOUNDATION ENGINEERING, 4., Budapest. Anais. p.829-836.

VARGAS, M. (1978) Introdução à mecânica dos solos. 1. ed., São Paulo, McGrawHill do Brasil.

VARGAS, M. (1992) Solos porosos e colapsíveis - Aula inaugural de 1992. São Carlos, Publicação EESC/USP 079/93.

VELLOSO, D.A. (1959) A resistência à subpressão por meio de estacas de tração. Portos e Navios, nov.-dez.

VÉSIC, A.S. (1970) Test on instrumented piles, Ogeeche river site. Journal of the Soil Mechamics and Foundation Division, ASCE, v.96 , n.2, p.561-584.

VILAR, O.M. (1979) Estudo da compressão unidirecional do sedimento moderno (solo superficial) da cidade de São Carlos. São Carlos, 105 p. (Mestrado - Escola de Engenharia de São Carlos, USP).

ZARETSKII, Y.K. \& KARABAEV, M.I. (1987) Analysis of settlements of boredcast-in-place piles in collapsible soils. Soil Mechanics and Foundation Engineering, ASCE, Jan/Fev, 24 (1): p.13-19.

ZEEVAERT, L. (1983) Foundation engineering for difficult subsoil conditions. 2. ed., Van Mostrand Reinhold. 


\section{OBRAS CONSULTADAS}

BARRAUD, M.Y. (1962) Contribution a l'étude expérimentale des fondations sollicitées a l'arrachement. Bulletin de la Societé Françoise des Electriciens, septembre.

BIAREZ, J. \& TRAN-VON-NHIEM (1971). Force maximale de soulevement des fondations d'ancrage en milieu pulverulent bidimensionnel. In: ASIAN REGIONAL CONFERENCE ON SOIL MECHANICS AND FOUNDATIONS ENGINEERING, 4., Bangkok, Thailand, 1971. Proceedings, p. 417-422.

CHATTOPADHYAY, B.C. (1994) Uplift capacity of pile groups. In: INTERNATIONAL CONFERENCE ON SOIL MECHANICS AND FOUNDATIONS ENGINEERING, 13., New Delhi, India, 1994, (1): 539-542.

CHATTOPADHYAY, B.C. \& PISE, P.J. (1989) Load displacement and ultimate resistance of piles under oblique pull. Journal of Geotechnical Engineering, (20): 19-38.

DIAS, R.D. (1985) Fundações de linhas de transmissão assentes em solos lateríticos. In: In: SEMINÁRIO DE ENGENHARIA DE FUNDAÇÕES ESPECIAIS, São Paulo, 1991. São Paulo, ABMS, (2): p.283-289.

DICKIN, E.A. \& LEUNG, C.F. (1990) Performance of piles with enlarged bases subject to uplift forces. Canadian Geotechnical Journal, (27): 546-556.

DICKIN. E.A. \& LEUNG, C.F. (1992) The influence of foundation geometry on the uplift behavior of piles with enlarged bases. Canadian Geotechnical Journal, (29): 498-505.

GENDEL, E.M. (1986) Prevention and elimination of settlements of buildings and structures constructed on soils of type II collapsibility. Soil Mechamics and Foundations Engineering, 23 (6): 224- 227. 
GRIGORYAN, A.A. \& GRIGORYAN, R.G. (1975). Experimental Study of Negative Skin Friction of Piles in the Case of Slumping of Soils From Their Own Weight. Soil Mechanics and Foundation Engineering. Vol. 12. n. 5. p.292.

GUPALENKO, V.I. \& RUDENKO, A.A. (1976). Performance of piles cast in predrilled holes and consolidated masses during slump-type settlements of soils surrounding them due to their own weight. Soil Mechanics and Foundations Engineering, (2): 126-129.

HANNA, A.M. \& AFRAM, A. (1986) Pull-out capacity of single batter piles in sand. Canadian Geotechnical Engineering, (23): 387-392.

ISMAEL, N.F. (1989) Field tests on bored piles subjected to axial and oblique pull. Journal of Geotechnical Engineering, ASCE, 115(11): p.1588-1589.

ISMAEL, N.F. \& AL. SANAD, H.A. (1986) Uplift capacity of bored piles in calcareous soil. Journal of Geotechnical Engineering, ASCE, 112(10): p.928940.

JOSHI, R.C.; ACHARI, G. \& KANIRAJ, S.R. (1992) Effect of loading history on the compression and uplift capacity of driven model piles in sand. Canadian Geotechnical Journal, (29): 334-341.

JUSTO, J.L; JUSTO, E.; ROMERO, R.; CANDELA, J. \& SOLA, P. (1994) The evaluation of pile loading tests in tension and compression. In: In: INTERNATIONAL CONFERENCE ON SOIL MECHANICS AND FOUNDATIONS ENGINEERING, 13., New Delhi, India, 1994, (1): 241-244.

KRUTOV, V.I.; KAPUSTIN, V.K.; GINZBURG, L.K.; KOVAL', V.E.; OPERSHTEIN, V.L. \& GUDAKOV, Y.S. (1984) Method and results of testing piles tamped into holes drilled in soils classed as type II in terms of proneness to slump-type settlement. (In order to discussion). Soil Mechanics and Foundations Engineering, 21 (3): 101- 104.

KULHAWY, F.H; KOZERA, D.W \& WITHIAM, J.L (1979) Uplift testing of model drilled shafts in sand. Jounal of the Geotechnical Division, ASCE, v.105, GT1, p.31-47. 
MAL'TSEV, A.T. \& SHZHIN, V.S (1980) Behavior of short piles in collapsible soils under the action of inclined forces. Soil Mechanics and Foundations Engineering, 17 (3): p. 235-239.

MARTIN, M. (1975) Calcul a l'arrachement des fondations. Electra, (38): 53-88.

MEYERHOF, G.G \& GHOSH, D.P. (1989) Ultimate capacity of flexible piles under eccentric and inclined loads. Canadian Geotechnical Journal, (26): 34-42.

MILITITSKY, J. (1991) Provas de carga estáticas. In: SEMINÁRIO DE ENGENHARIA DE FUNDAÇÕES ESPECIAIS, 2., São Paulo, 1991. Anais. São Paulo, ABMS, (2): p.203-228.

STEWART, W. (1985) Uplift capacity of circular plate anchors in layered soil. Canadian Geotechnical Journal, Notes, (22): 589-592.

SULLY, J.P. (1994) Use of full-displacement penetration tests to determine in situ lateral stress. In: INTERNATIONAL CONFERENCE ON SOIL MECHANICS AND FOUNDATIONS ENGINEERING, 13., New Delhi, India, 1994, (1): 139142 .

SU, W. \& FRAGASZY, R. (1988) Uplift testing of model anchors. Journal of Geotechnical Engineering, 114 (9): 961-983.

TRAUTMANN, C.H. \& KULHAWY, F.H. (1988) Uplift load-displacement behavior of spread foundations. Journal of Geotechnical Engineering, 114 (2): 168-184.

ZEKHNIEV, F.F; KONOVALOV, P.A \& KHMEDOV, D.D. (1994) Consolidation of loess soil with account of disturbed zone around drain. In: INTERNATIONAL CONFERENCE ON SOIL MECHANICS AND FOUNDATIONS ENGINEERING, 13., New Delhi, India, 1994, (1): 103-106. 